RAFAEL DE FIGUEIREDO SILVA PINHEIRO

\title{
Da Patenteabilidade de Genes Humanos
}

MESTRADO EM DIREITO

ORIENTADOR: PROFESSOR DOUTOR NEWTON SILVEIRA

UNIVERSIDADE DE SÃO PAULO

FACULDADE DE DIREITO

São Paulo - SP 
RAFAEL DE FIGUEIREDO SILVA PINHEIRO

\title{
Da Patenteabilidade de Genes Humanos
}

\begin{abstract}
Dissertação apresentada à Banca Examinadora da Faculdade de Direito da Universidade de São Paulo, como exigência parcial para obtenção do título de Mestre Direito, na área de concentração Direito Comercial, sob a orientação do Prof. Dr. Newton Silveira
\end{abstract}

UNIVERSIDADE DE SÃO PAULO

FACULDADE DE DIREITO

São Paulo - SP

2015 
Nome: PINHEIRO, Rafael de Figueiredo Silva

Título: Da Patenteabilidade de Genes Humanos

Dissertação apresentada à Faculdade de Direito da Universidade de São Paulo para obtenção de título de mestre em Direito Comercial

Banca Examinadora: 


\section{RESUMO}

PINHEIRO, RAFAEL F.S. Da Patenteabilidade de Genes Humanos. 2015. 276p. Dissertação (Mestrado em Direito) - Faculdade de Direito, Universidade de São Paulo.

São inegáveis o caráter universal e a importância dos avanços tecnológicos e científicos originados das pesquisas genéticas. O sequenciamento do genoma humano, a identificação das principais sequências de DNA contidas nos seus genes e suas respectivas funções biológicas, bem como suas possíveis aplicações biomédicas, são de incalculável importância. Os genes, muito embora possam ser biologicamente caracterizados como compostos químicos, possuem um conteúdo informacional que se revela indispensável ao desenvolvimento da engenharia genética, figurando como elemento básico e central de suporte às inovações biotecnológicas. Desta forma, importante analisar a relevância da aplicação de mecanismos jurídicos como forma de fomento à contínua evolução biotecnológica sob a ótica do desenvolvimento econômico e social do país, princípios constitucionais justificadores da proteção de referidos desenvolvimentos técnicos por meio do intelecto e intervenção humanos na natureza. Para tanto, deve-se levar em consideração que a inexistência de tutela jurídica específica pode gerar desincentivo aos investimentos capazes de possibilitar o desenvolvimento de tais tecnologias, ao passo que uma tutela jurídica muito ampla poderá ocasionar indevida restrição ao acesso a tais "insumos" biológicos, de modo a gerar um efeito adverso àquele buscado. Assim, deve-se compatibilizar a proteção dos resultados obtidos através do desenvolvimento biotecnológico em relação à potencial dificuldade originada de uma eventual restrição ao acesso a tais elementos fundamentais à pesquisa e desenvolvimento genéticos. É neste contexto que se procura um balizamento entre os diferentes interesses e posicionamentos a respeito da patenteabilidade dos genes humanos, visando solução jurídica que permita um ambiente seguro e propício ao desenvolvimento da engenharia genética, e dos inúmeros benefícios que poderão daí se originar. O presente estudo se voltará, portanto, à análise da necessidade, condições, suficiência e extensão da tutela jurídica a ser conferida pela outorga de direitos patentários aos genes humanos.

Palavras-chave: patente - propriedade intelectual - biotecnologia - genética - genes DNA. 


\begin{abstract}
PINHEIRO, RAFAEL F.S. Human Genes Patenting. 2015. 276p. Master in Law, Dissertation - Faculty of Law, São Paulo University.

The importance and universal character of the scientific and technologic development in connection with research and development in the field of genetic engineering are unquestionable. The human genome sequencing, the identification and marking of important DNA sequences within their respective genes, as well as their biological functions and features are of utmost importance - not to mention the possible biomedical uses and applications. Although the genes can be biologically defined as chemical compounds, it is the genetic information carried by them that reveals their relevance in the development of the genetic engineering, for it plays a key role of basic research tool for biotechnological innovation. In this background arises the discussion regarding the importance of implementing legal mechanisms aiming at fostering the continuous development of the biotechnology in view of the social and economic growth, which are the grounds to legitimate the protection of such forms of innovations brought up by the human intervention in the nature. For the purposes thereof, on one hand it must be taken into account that a scenario where no rules governing such protection are applied could discourage new investments, while, on the other hand, a broad legal protection could lead to an unjustified restriction to the access of basic biological elements that would enable new gene-based biotechnical developments, in which case there might be an adverse effect in relation to the one originally sought. As a result, it is important to analyze the possibility to accommodate the protection of the results obtained from biotechnological developments in view of the possible difficulties that may arise from the restriction of the fundamental elements required for forthcoming developments. In view of the aforementioned scenario, the present study seeks to find a balance among the different interests and opinions with respect to the human genes patenting in order to find the most efficient and secure legal framework to enable genetic engineering development due to the numerous benefits that are expected to arise therefrom. In short, this dissertation will focus on the analysis of the necessity, conditions, sufficiency and length of patent protection to human genes.
\end{abstract}

Keywords: patents - intellectual property - biotechnology - genetic - genes - DNA. 


\section{SIGLAS E ABREVIATURAS}

\begin{tabular}{|c|c|c|}
\hline ABPI & - & Associação Brasileira de Propriedade Intelectual \\
\hline ASS & & Ácido Acetilsalicílico \\
\hline ANVISA & - & Agência Nacional de Vigilância Sanitária \\
\hline CADE & - & Conselho Administrativo de Defesa Econômica \\
\hline CCTCI & - & Comissão de Ciência e Tecnologia, Comunicação e Informática \\
\hline CDB & - & Convenção sobre Diversidade Biológica \\
\hline CDEIC & - & Comissão de Desenvolvimento Econômico, Indústria e Comércio \\
\hline cDNA & - & DNA complementar \\
\hline $\mathrm{CF} / 88$ & - & Constituição Federal do Brasil de 1988 \\
\hline CGEN & - & Conselho de Gestão do Patrimônio Genético \\
\hline CJEU & - & Court of Justice of the European Union ou Tribunal de Justiça Europeu \\
\hline CMADS & - & Comissão do Meio Ambiente e Desenvolvimento Sustentável \\
\hline $\mathrm{CNB}$ & - & Centro Nacional de Biotecnologia \\
\hline CNBS & - & Conselho Nacional de Biossegurança \\
\hline CTNBio & - & Comissão Técnica Nacional de Biossegurança \\
\hline CUP & - & Convenção de Paris \\
\hline DGPI & - & Diretoria Geral de Propriedade Industrial \\
\hline DNA & - & Ácido Desoxirribonucleico \\
\hline ENCTI & - & Estratégia Nacional de Ciência, Tecnologia e Inovação \\
\hline EPC & - & European Patent Convention ou Convenção Europeia de Patentes \\
\hline EPO & - & European Patent Office ou Escritório de Patente Europeu \\
\hline ESTs & - & Expressed Sequence Tags ou Marcadores de Sequências Expressas \\
\hline EUA & - & Estados Unidos da América \\
\hline INPI & - & Instituto Nacional de Propriedade Industrial \\
\hline LPI & - & Lei 9.279/1996 ou Lei de Propriedade Industrial \\
\hline MPEP & - & Manual of Patent Examining Procedure \\
\hline mRNA & - & RNA mensageiro \\
\hline OCDE & - & Organização da Cooperação para o Desenvolvimento Econômico \\
\hline OGMs & - & Organismos Geneticamente Modificados \\
\hline OMPI & - & Organização Mundial de Propriedade Intelectual \\
\hline ORF & - & Open Reading Frame ou Fases Abertas de Leitura \\
\hline
\end{tabular}




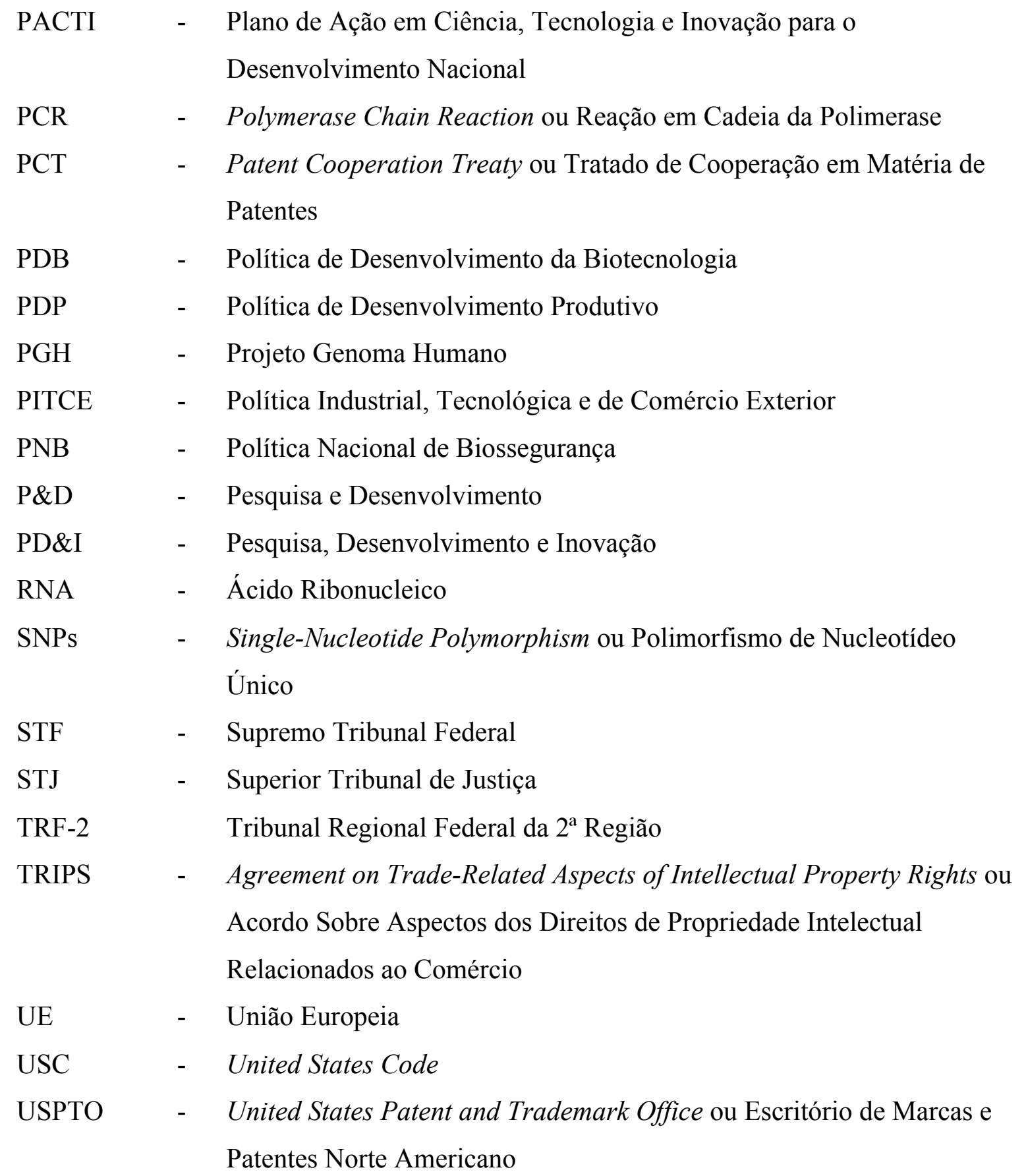




\section{SUMÁRIO}

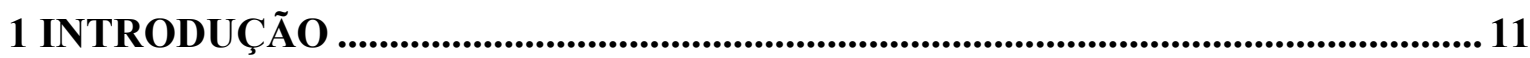

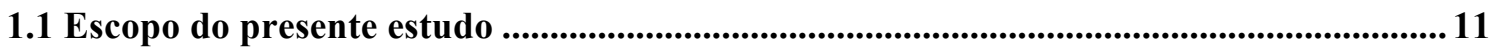

1.2 Identificação dos principais aspectos controversos e âmbitos de discussão ....................... 14

1.3 Delimitação do objeto de estudo ......................................................................................................... 21

2 DESENVOLVIMENTOS BIOTECNOLÓGICOS ...................................................... 23

2.1 A evolução biotecnológica ................................................................................................................. 23

2.2 Conceitos preliminares de biologia molecular e genética........................................................26

2.2.1 Material biológico: conceito e classificação; materiais biológicos vivos e não-vivos;

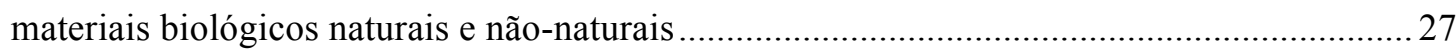

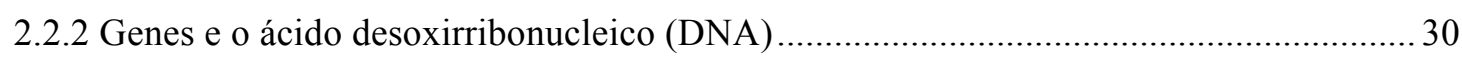

2.2.3 Informação Genética: sequenciamento e genoma ........................................................... 33

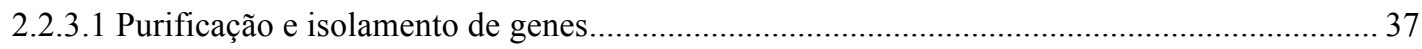

2.2.3.2 Produção de materiais biológicos de modo sintético ……………………………................... 40

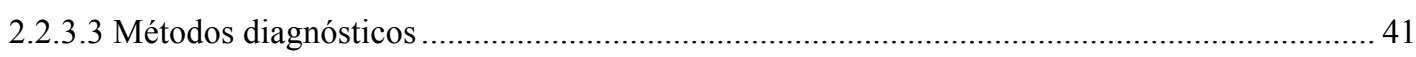

2.2.3.4 Engenharia genética como desenvolvimento biotecnológico …………………..................... 42

2.3 Materiais biológicos como instrumentos de pesquisa para invenções subordinadas ..... 43

3 O SISTEMA PATENTÁRIO COMO FORMA DE PROTEÇÃO DE INVENÇÕES

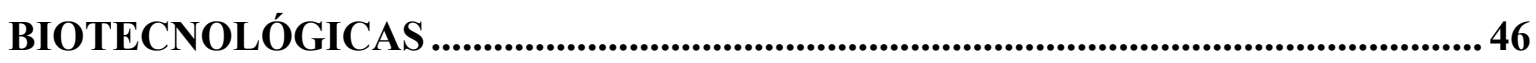

3.1 A proteção da propriedade intelectual aplicada ao âmbito biotecnológico......................... 46

3.1.1 Os desenvolvimentos biotecnológicos como segredos de negócio ..................................55

3.1.2 $\mathrm{O}$ amparo da lei de direitos autorais à pesquisa e desenvolvimento em biotecnologia ... 58

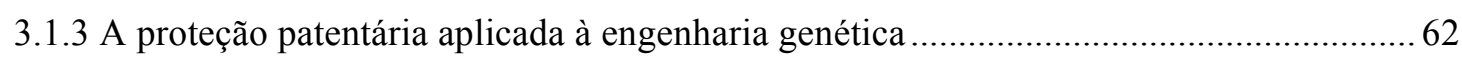

3.2 Princípios e objetivos do sistema patentário ...................................................................66

3.3 Conceito e fundamento de validade das patentes ........................................................... 70

3.4 Classificação das patentes e aplicação em âmbito biotecnológico...................................... 75

3.5 Condições de patenteabilidade ........................................................................................................ 80

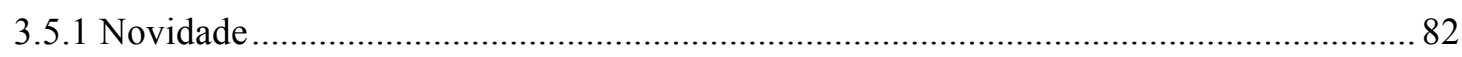

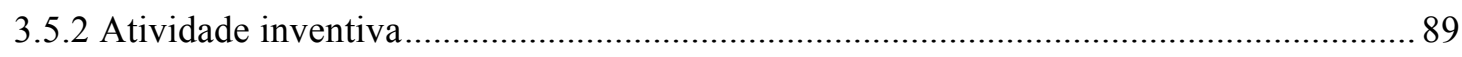

3.5.3 Aplicação industrial e o critério da utilidade .................................................................... 95

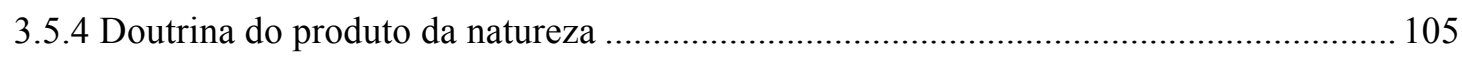

3.6 Limitações ao exercício do direito patentário ..................................................................... 112

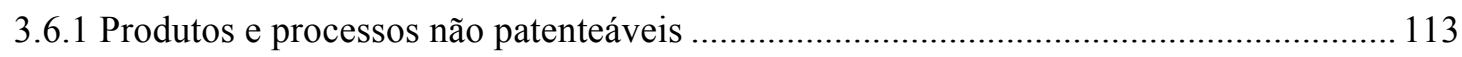

3.6.2 Intervenção da Anvisa nos processos de patentes biotecnológicas ................................ 114

3.6.3 Legítima utilização de patentes por terceiros ............................................................... 114 
3.6.4 Licenciamento Compulsório.

4 PATENTEAMENTO DE GENES E RESTRIÇÃO AO ACESSO A

INFORMAÇÕES BIOTECNOLÓGICAS .............................................................. 119

4.1 Invenções pioneiras e desenvolvimentos subsequentes ...................................................119

4.2 Desenvolvimentos biotecnológicos na ausência de proteção patentária .......................... 122

4.3 Extensão do âmbito de proteção dos genes no sistema patentário ...................................... 127

4.3.1 Proteção patentária absoluta ....................................................................................... 130

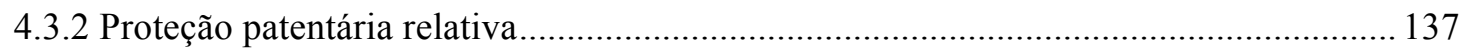

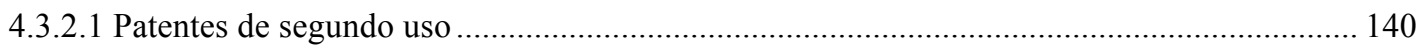

5 A EXPERIÊNCIA BRASILEIRA E O DIREITO COMPARADO............................ 148

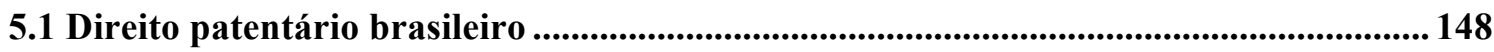

5.1.1 Origens e evolução do direito patentário brasileiro ..................................................... 150

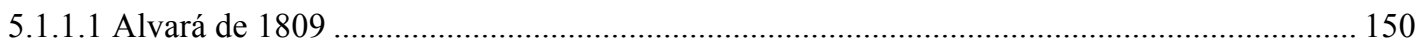

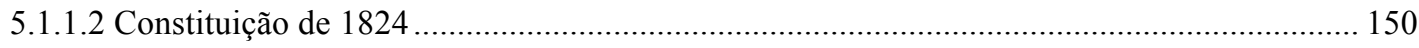

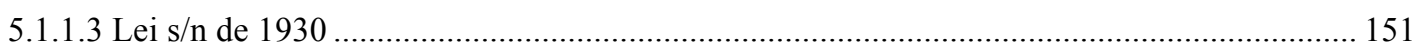

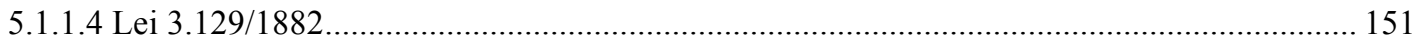

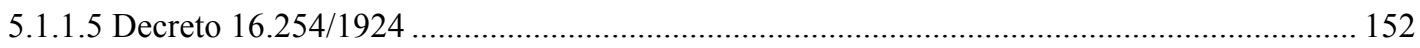

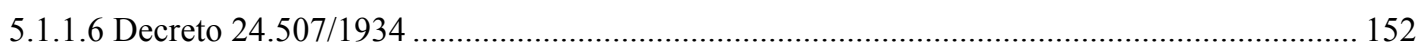

5.1.1.7 Códigos de Propriedade Intelectual de 1945, 1969 e 1971 ............................................... 152

5.1.1.8 Lei 9.279/1996 (Lei de Propriedade Industrial) …………………………………........... 155

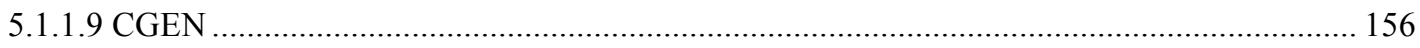

5.1.1.10 Lei 11.105/2005 (Lei de Biossegurança) ……………………………………………….... 157

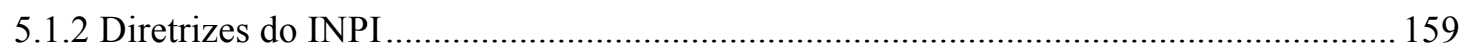

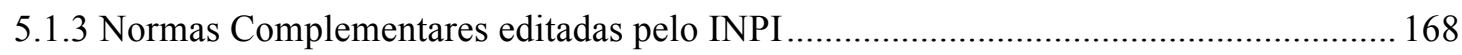

5.1.4 Propostas de Modificações na Lei de Propriedade Intelectual em Biotecnologia .......... 171

5.1.4.1 Projeto de Lei 2.695/2003 ............................................................................................. 171

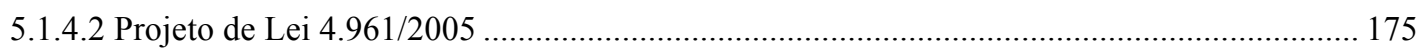

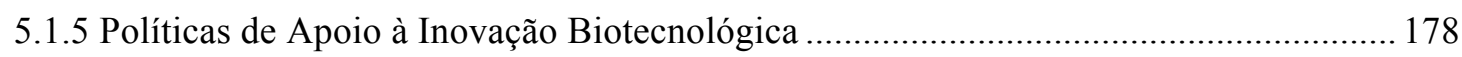

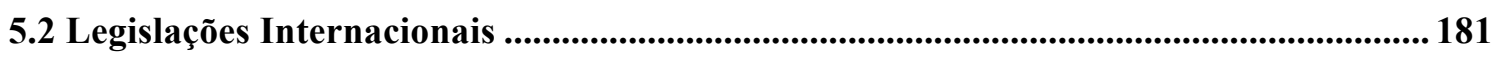

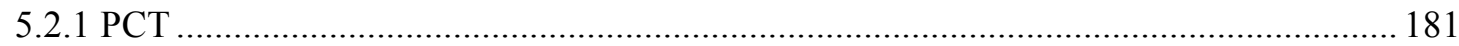

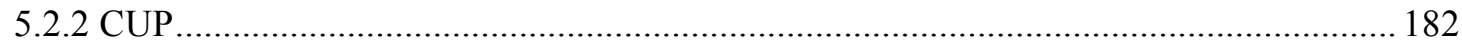

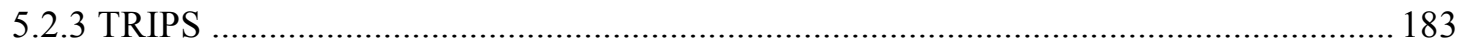

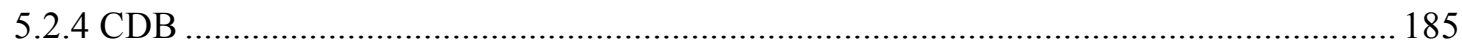

5.3 Evolução legislativa e jurisprudencial em matéria de biotecnologia nos EUA...............186

5.3.1 Legislação de patentes e proteção biotecnológica nos EUA …………………………... 187

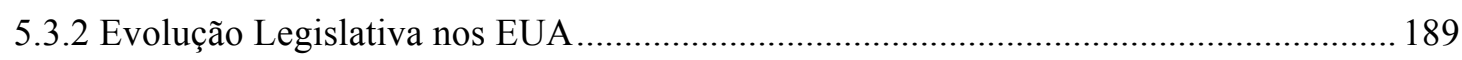

5.3.3 A Evolução do USPTO no tratamento das patentes biotecnológicas ............................. 191

5.3.4 Evolução jurisprudencial americana em matéria de proteção biotecnológica................ 197 


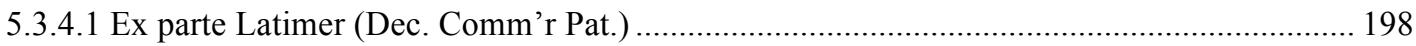

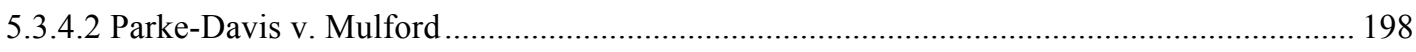

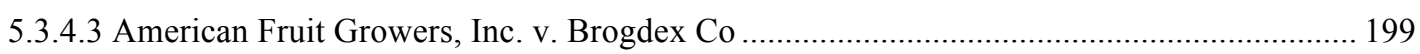

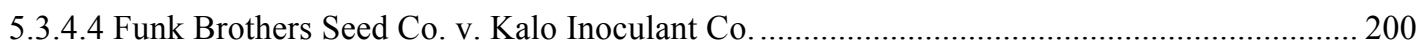

5.3.4.5 Merck\&Co. v. Olin Mathieson Chemical Corp. ..................................................................... 201

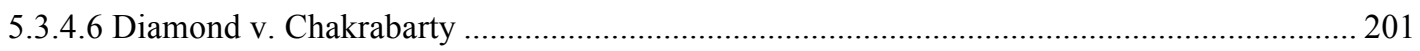

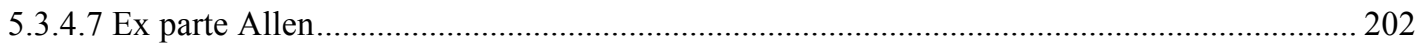

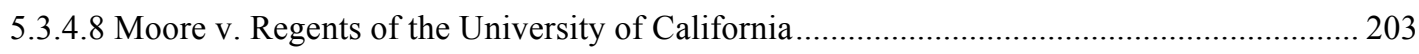

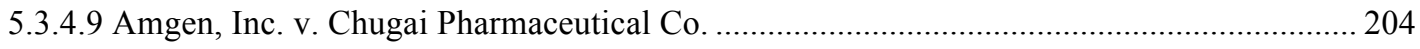

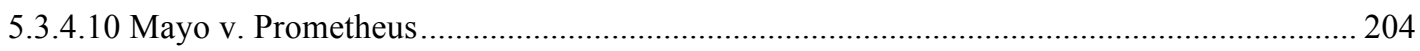

5.3.4.11 Association for Molecular Pathology v. Myriad Genetics .................................................. 209

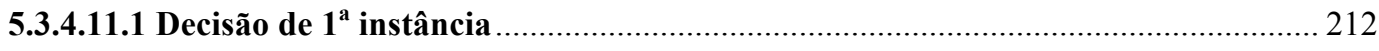

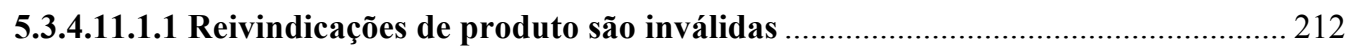

5.3.4.11.1.2 Reivindicações de método são inválidas ....................................................... 217

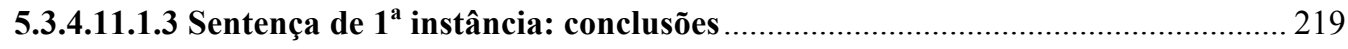

5.3.4.11.2 Reforma da Decisão de Primeira Instância ………………………………………….... 220

5.3.4.11.2.1 Conceito de matérias patenteáveis .................................................................. 221

5.3.4.11.2.2 Reivindicações de moléculas de DNA isoladas............................................... 221

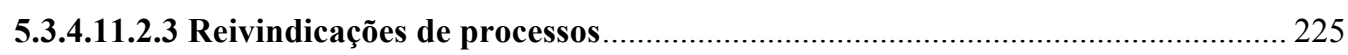

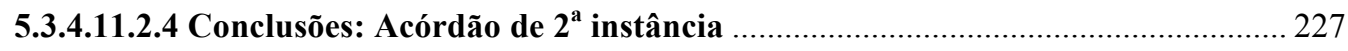

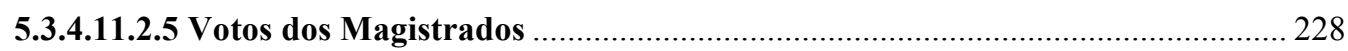

5.3.4.11.3 A Decisão da Suprema Corte Americana ……………………………………..... 236

5.4 Evolução legislativa e jurisprudencial em matéria de biotecnologia na UE ................... 238

5.4.1.1 Patenteamento de invenções biotecnológicas na UE ........................................................... 245

5.5 Requerimentos de patenteabilidade em geral - análise comparativa............................... 247

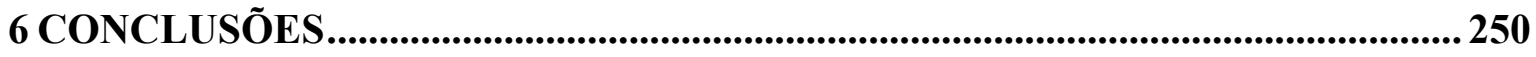

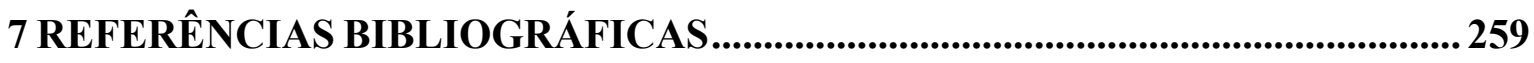




\section{INTRODUÇÃO}

\subsection{Escopo do presente estudo}

A biotecnologia diz respeito ao conjunto de técnicas e tecnologias que têm por objeto a utilização de material biológico, com o fim de extrair dele uma finalidade útil e prática para satisfazer as necessidades humanas.

A engenharia genética se insere de forma destacada no contexto das inovações biotecnológicas, em virtude de um amplo horizonte de conhecimento ainda inexplorado, mas que aponta para um ambiente capaz de gerar inúmeros e importantes benefícios ao homem, em especial no que tange à área biomédica ${ }^{1}$.

Dentre as aplicações potenciais da engenharia genética que evidenciam a importância de seu contínuo desenvolvimento, destacam-se aquelas relativas à medicina molecular, tais como informações sobre a evolução da espécie, a possibilidade de diagnóstico de doenças genéticas e infecciosas, a identificação de predisposição genética para o desenvolvimento de determinadas doenças, o desenvolvimento de medicamentos e terapias gênicas, produção de substâncias úteis e transgênicos, dentre outros. Nada obstante, muitas outras possíveis aplicações, inclusive em relação a outras áreas do conhecimento, poderão também estar a ela relacionadas, tudo resultado de estudos técnicos que terão por base a exploração do conteúdo informacional identificado pelo sequenciamento do genoma humano.

A engenharia genética representa, portanto, uma forma de interferência técnica direta do homem em matérias biológicas/orgânicas, em especial nas unidades básicas formadoras e controladoras do ser humano, os genes. Por se tratar de ramo do conhecimento bastante promissor, e que, portanto, tem despertado grande interesse em todo o mundo, mostra-se relevante a discussão dos possíveis meios capazes de gerar incentivos a pesquisas e desenvolvimento no setor - especialmente em razão dos altos

\footnotetext{
1 "Biotechnology has proven itself to be one of the most promising and volatile sectors in the world economy. From genetic engineering to the mapping of human cell lines, biotechnology is now a multibillion dollar venture." (OSTERGARD Jr, Robert; TUBIN, Matthew; ALTMAN, Jordan. Stealing from the past: globalisation, strategic formation and the use of indigenous intellectual property in the biotechnology industry. Third World Quarterly, vol. 22, n 4, 2001, p. 643).
} 
investimentos demandados, no mais das vezes atrelados a um alto risco de não serem alcançados os resultados buscados -, observando sempre como tais políticas poderão reverter em benefícios à sociedade como um todo.

Mostra-se de grande importância para a biotecnologia, portanto, que seja garantida uma rápida e contínua difusão de informações e conhecimentos como forma de se garantir o progresso biotecnológico, que tem, como característica básica para seu desenvolvimento, a cumulatividade de conhecimentos; para tanto, deve-se incentivar a livre troca de informações para se fomentar pesquisas e o desenvolvimento no setor. Contudo, imperioso se faz considerar até que ponto se justifica a concessão de direitos de propriedade aos criadores de tais produtos e processos biotecnológicos, como forma de se atrair os necessários investimentos.

Apenas para melhor delimitar o tema objeto do presente estudo, importa aqui esclarecer que a análise acerca da patenteabilidade de genes humanos não envolverá quaisquer considerações relativas a inovações no âmbito da engenharia genética que busquem a modificação genética de organismos que envolvam, por exemplo, a clonagem e/ou a realização de melhoramentos/modificações genéticas de seres vivos (OGMs).

Dito isso, a fim de melhor contextualizar o ambiente em que se insere a análise objeto do presente estudo, serão inicialmente abordados aspectos relacionados à evolução biotecnológica, bem como seu atual estágio de desenvolvimento.

Após esta breve introdução histórica, serão delineados os conceitos básicos de biologia molecular aplicados em âmbito da engenharia genética, em especial acerca da conceituação, características e funções dos genes - especialmente o caráter químico dos genes e as informações por eles carreadas.

Será em seguida avaliado o impacto dessas novas tecnologias na sociedade, bem como aferida a importância de se utilizarem mecanismos de fomento à evolução biotecnológica, para fins de viabilizar um estudo crítico acerca da (necessidade de) proteção de produtos biotecnológicos, em especial dos genes humanos. 
A busca pela função social dos institutos jurídicos aptos a proteger de forma legítima e eficaz os desenvolvimentos e resultados intelectuais no campo biotecnológico mostra ser questão fundamental ao presente estudo, de modo que serão também analisadas as possíveis formas jurídicas capazes buscar tal resultado, reconhecendo-se a aplicabilidade da proteção patentária como a mais adequada.

A discussão dos requisitos autorizadores da proteção patentária aplicados no contexto dos desenvolvimentos biotecnológicos também será considerada, sendo este um dos principais aspectos a serem tratados no presente trabalho, em razão de suas peculiaridades - que as distinguem das invenções tradicionais, mecânicas. Serão então verificadas as situações de exclusão da proteção patentária e critérios que podem admitir a inclusão de referidos tipos de patentes biotecnológicas, desde que presentes as condições de patenteabilidade.

Ademais, o relacionamento entre fundamento jurídico do sistema de patentes e sua racionalidade econômica será estudado, a fim de que se possa promover uma compreensão completa do significado e amplitude a ser conferido à proteção patentária aos genes humanos. Assim, respostas ao problema de restrição ao acesso a genes patenteados devem ser consideradas e algumas soluções podem ser propostas e analisadas, a fim de se determinar o modelo capaz de atingir os objetivos pretendidos pela aplicação do sistema patentário de modo mais adequado e eficiente.

Por fim, será estudada a evolução do direito patentário no Brasil e no direito comparado, com vistas aos novos desenvolvimentos que vêm sendo trazidos pela biotecnologia. Primeiramente, tratar-se-á das origens e evolução do entendimento legal, doutrinário e jurisprudencial brasileiro, no que diz respeito aos desenvolvimentos biotecnológicos. Em seguida, passa-se a uma análise similar no direito comparado, tomando-se como referências principais os Estados Unidos e a União Europeia.

A título de conclusão, a preocupação será em promover uma integração de todos esses aspectos, conciliando os aspectos técnicos jurídicos aos conceitos biotecnológicos e econômicos, a fim de se concluir pela forma mais eficiente de se tutelar os produtos e processos originados da engenharia genética. 


\subsection{Identificação dos principais aspectos controversos e âmbitos de discussão}

O direito deve abordar o progresso da biotecnologia, estando apto a disciplinar tais intervenções do ser humano sobre materiais biológicos, bem como seus potenciais desdobramentos. Deve-se, portanto, avaliar se os sistemas jurídicos atuais estão totalmente adaptados para esta nova realidade, ou se merecem ajustes para que possam regulamentá-la com maior eficiência.

Emerge desta constatação uma série de questões e posições antagônicas em diversos níveis, não só no Brasil, mas em todo o globo. Essa aparente incompatibilidade entre os mais diversos interesses que envolvem o tema tem gerado situações potencialmente capazes de impactar o desenvolvimento técnico-científico proporcionado pelas pesquisas genéticas.

Como será detalhado oportunamente, os genes são moléculas que coordenam o desenvolvimento e funcionamento de todos os seres vivos. O estudo do funcionamento dos genes - considerados isoladamente ou em conjunto - permite determinar as funções e importância biomoleculares de cada um, e a partir daí suas respectivas eventuais aplicações biológicas.

Os genes, entendidos como composições bioquímicas existentes na natureza, em princípio não poderiam ser objeto de apropriação privada. Entretanto, apesar de serem compostos químicos existentes na natureza, sua forma isolada ou sintetizada em laboratórios possui características distintivas, originadas da intervenção humana, que não podem ser espontaneamente reproduzidas pela natureza e cujas possíveis aplicações e utilidades podem configurar possível atividade inventiva. Tais produtos biotecnológicos assim obtidos se distinguiriam do gene verificado em sua forma natural, de forma suficiente para se possibilitar seu patenteamento, mediante reivindicação de patentes relacionadas e aplicações úteis devidamente descritas.

Em virtude do impacto das novas tecnologias originadas da evolução da engenharia genética na sociedade, importa avaliar a relevância de se utilizarem mecanismos jurídicos 
de fomento à evolução biotecnológica e atendimento ao interesse público, em especial no que tange ao acesso à saúde.

É sabido que investimentos em biotecnologia são demasiadamente altos, com retornos incertos e sempre verificados a longo prazo. Por essa razão, sustenta-se que, em âmbito privado, seria de grande relevância a existência de uma tutela que garanta direitos exclusivos de exploração aos produtos dela originados, para que se justifiquem referidos investimentos.

O debate a respeito da apropriação dos genes, que são as peças fundamentais para se possibilitar tal desenvolvimento, é chave. Por conseguinte, esta questão é debatida em diversos níveis e envolve os mais variados interesses, frequentemente esbarrando em questionamentos de cunho ético, moral, biológico, econômico e político, e tudo isso deve ser acomodado juridicamente.

Neste contexto, a patente aparenta ser a ferramenta capaz de gerar tais incentivos. Ocorre que a proteção patentária deve ser vista sempre de forma restritiva, pois a promoção do desenvolvimento científico deverá ser sempre legitimada pelo atingimento ao interesse público.

No campo da engenharia genética, é importante se atentar para algumas peculiaridades que poderão ser determinantes para o estabelecimento de uma tutela jurídica capaz de atingir um equilíbrio justo e necessário.

Em primeiro lugar, deve-se levar em consideração que possuem os desenvolvimentos biotecnológicos indubitavelmente grande importância e interesse públicos. Por óbvio, tais desenvolvimentos decorrem diretamente de esforços originados do intelecto humano que, para se tornarem viáveis, dependem de vultosos investimentos.

No caso da engenharia genética, é também sabido que os genes - muito embora matérias-primas originadas na natureza - somente passam a ter aplicações e funções técnicas úteis ao homem (e distintas de suas finalidades originais) a partir do momento em que são tratados, replicados, copiados ou produzidos após intervenção laboratorial - e que não ocorrem naturalmente. 
Tal fato, por outro lado, leva à conclusão de que a principal característica dos genes reside no seu conteúdo informacional, sendo este um elemento de base potencialmente útil para diversas "invenções" biotecnológicas, e que não possui substituto. Sob esta ótica, a proteção conferida pelas patentes (estas consideradas em seu sentido tradicional) poderia deixar de atender ao interesse público, por limitar o livre acesso a tais matérias-primas. A proteção patentária dos genes poderia privatizar todo o seu conteúdo informacional, o que - em virtude do âmbito de extensão que venha a ser conferido - resultaria em restrição do acesso a tais ferramentas genéticas de base para aplicações em produtos e processos futuros.

Ponto pacífico é que se deve, sempre, viabilizar e promover o desenvolvimento técnico-científico na área da engenharia genética. Entretanto, e superada a questão da existência dos pressupostos materiais autorizadores da patente de genes, posições antagônicas surgem também desta afirmação:

(a) Os genes que formam o genoma humano devem ser mantidos em domínio público, isto é, estar livremente disponíveis para encorajar a pesquisa e desenvolvimento, maximizando os benefícios daí originados para toda a sociedade. Sob esta perspectiva, defende-se que patentes de genes podem obstruir o futuro da inovação por dificultar a procura de usos alternativos para um gene patenteado.

(b) Em contraposição, o patenteamento de genes seria justamente uma forma de se promover a pesquisa e o desenvolvimento, em especial o avanço em pesquisas clínicas capazes de beneficiar pacientes. O sistema de patentes oferece a possibilidade de atrair investidores para aplicarem recursos em pesquisas destinadas ao desenvolvimento da engenharia genética, pela garantia de retorno originada do "monopólio" na exploração econômica dessas inovações durante o período de vigência de uma patente. Mais do que isso, tal prática permite e provoca a divulgação de inovações promovidas pela pesquisa genética, uma vez que os inventores e seus financiadores terão uma motivação econômica para assim se comportar, qual seja, a exploração da patente em caráter exclusivo por determinado período. 
Por questões metodológicas, esses diferentes focos de debate foram agrupados em 3 grandes blocos, quais sejam, (a) os aspectos técnico-jurídicos; (b) os aspectos econômicos; e (c) os aspectos morais.

Em primeiro lugar, existem discussões em âmbito técnico-jurídico relacionadas ao cumprimento de requisitos de patenteabilidade pelas invenções biotecnológicas, basicamente relacionadas aos requisitos de novidade e atividade inventiva, em razão de estarem diretamente relacionadas - em última análise - a materiais biológicos já previamente existentes na natureza.

No contexto nacional, será analisado o atual arcabouço normativo aplicável à matéria, de modo a se contextualizar todo o histórico do desenvolvimento técnicocientífico atribuível ao Brasil na área da engenharia genética. Em seguida, um estudo comparado com os países que estão na vanguarda da engenharia genética permitirá a determinação de uma correlação entre tais aspectos, bem como a eventual identificação de padrões em países que adotem uma mesma orientação legal quanto à patenteabilidade de genes humanos.

Tais aspectos, juntamente com a análise da discussão acerca da existência dos critérios materiais ensejadores da concessão de patentes a genes humanos, poderão auxiliar na verificação da hipótese que se pretende trabalhar por meio do presente estudo, qual seja, determinar se existe a viabilidade de se promoverem reformas legislativas, adequadas ao sistema jurídico nacional, que sejam capazes de atrair investimentos privados em pesquisa e desenvolvimento na medicina genética pela eventual concessão de patentes.

Em caso positivo, questiona-se quais seriam as condições e limites aplicáveis para se evitar que a outorga de poder monopolístico para exploração de referidas patentes afronte o interesse público, bem assim tenha como resultado adverso justamente o que se pretende promover: o desenvolvimento técnico-científico no ramo da engenharia genética.

Uma aprofundada análise e discussão desses fatores é feita no Capítulo 3 deste estudo, e retomada posteriormente no Capítulo 5, que faz um estudo de direito comparado, além de analisar como o direito acompanhou a evolução biotecnológica e buscou regulamentá-la ao longo dos anos. 
Num segundo plano, argumenta-se economicamente a viabilidade e âmbito de proteção das patentes para fins de atingimento ao objetivo final do sistema de patentes: progresso técnico-científico e desenvolvimento econômico-social (art. 5º XIX, CF/88). Nada obstante, importante considerar a importância de se recompensar o resultado de esforços intelectuais daí originados. Neste contexto, o direito de exclusividade gerado pela proteção patentária no âmbito da genética, enquanto direto negativo outorgado ao seu titular (que passa a ter a faculdade de excluir terceiros de sua exploração) poderia ser um entrave ao desenvolvimento biotecnológico, porquanto inibiria a realização de importantes pesquisas subsequentes na área da biotecnologia.

Em que pese o inquestionável interesse público que envolve a questão da (não) patenteabilidade dos genes - em especial o humano - não se pode deixar de considerar a contribuição que a iniciativa privada pode conferir para o desenvolvimento técnicocientífico da medicina genética.

Claro que tal fato deve ser visto com ressalvas. A possibilidade de se patentear genes humanos - ainda que observados determinados critérios e limites na sua exploração - é obviamente fator determinante para que a iniciativa privada continue promovendo investimentos desta natureza. Caso contrário, tal desenvolvimento dependerá especialmente de políticas públicas, e isso poderá ocorrer em diferentes níveis e com diferentes prioridades em cada nação.

Isso quer dizer que a restrição ao acesso de determinadas "matérias-primas" da biotecnologia pela sua privatização poderia gerar desincentivos aos futuros inventores e investidores. Neste sentido, importante se faz a análise a respeito da pertinência da promoção do sistema de patentes para a proteção dos genes e qual deveria ser sua extensão, por serem potencialmente consideradas ferramentas de pesquisas geradoras de novos produtos biotecnológicos.

Uma detida análise desses aspectos integra também o escopo do presente estudo, em especial no Capítulo 4. 
Por fim, os argumentos de ordem moral embasam o entendimento de que o patenteamento de genes humanos também poderia violar a dignidade humana. Conforme bem observa BAQUERO:

\begin{abstract}
"Certamente, uma das matérias em que as restrições éticas e morais à propriedade intelectual mais incidem é no campo do biodireito. Os grandes avanços alcançados na biotecnologia, permitindo a utilização de organismos vivos para fins comerciais especificos - incluidos ai partes do corpo humano, criou a necessidade de criar limites expressos a práticas que violassem o princípio da dignidade da pessoa humana. $O$ anedótico caso da patente de Edimburgo, posteriormente retificada pela Oficina Europeia de Patentes, que supostamente abrangeria células-tronco humanas, é um exemplo, dentre muitos outros, de caso em que tais restrições se fizeram presentes, especialmente em razão da grande oposição da sociedade civil.
\end{abstract}

Nesse sentido, diversos instrumentos internacionais estabeleceram principios que servem como limite a tais práticas. O Considerando $5^{\circ}$ da Declaração dos Direitos do Homem de 1948, estabelece o princípio da dignidade e do valor da pessoa humana, do qual decorre o princípio da não patrimonialidade do corpo humano.

Por sua vez, a Declaração Universal da UNESCO sobre o Genoma Humano e os Direitos Humanos, em consonância com esses princípios, estabelece no seu art. $1^{\circ}$ a noção de que o genoma humano é a base fundamental dos seres humanos, inerente à sua dignidade e diversidade e que, dessa forma, é patrimônio comum da humanidade, em sentido simbólico",2.

Logo, algumas posturas mais conservadoras defendem a exclusão dos genes humanos do âmbito de proteção patentária. Para aqueles que sustentam tal posicionamento, o genoma humano figura como patrimônio comum da humanidade. Neste sentido, o patenteamento de genes humanos equivaleria ao reconhecimento da possibilidade de a vida ser objeto de propriedade privada.

Por tal motivo, os genes em seu estado natural (ou seja, aqueles encontrados no corpo humano), não podem ser objeto de proteção patentária. Contudo, não é este o objeto

${ }^{2}$ BAQUERO, P. Propriedade Intelectual em Questão: entre a ética e o utilitarismo. O Caso da Patenteabilidade dos Genes Humanos. Revista dos Estudantes de Direito da Universidade de Brasília, n. 7 , 2008, p. 145-175. 
de proteção que se analisa ou se propõe. Neste sentido, MARQUES esclarece que as substâncias biológicas podem ter fontes (ou estados) distintos, sendo tal distinção importante para o âmbito do presente estudo: (a) a matéria biológica em seu ambiente natural, (b) a matéria biológica isolada de seu ambiente natural; e (c) a matéria biológica produzida com base num processo técnico ${ }^{3}$. Em relação ao genes, a discussão da tutela patentária que ora se propõe somente se aplica às substâncias estados indicados nos itens "b" e "c".

Apesar de figurarem como peças básicas para criação da vida, os genes deste modo considerados são meras substâncias químicas que carregam informação genética; em outras palavras, são matérias biológicas inanimadas, não vivas.

Portanto, à primeira vista - e sem negar a importância que têm discussões desta natureza - nenhuma diferença moral deveria existir entre o patenteamento de genes e o patenteamento de outras matérias ${ }^{4}$. Diante do quanto exposto, e a fim de se pontuar a controvérsia que ora se pretende mitigar, o presente estudo se voltará à análise e discussão acerca da necessidade, condições, suficiência e extensão da tutela jurídica a ser conferida pela outorga de direitos de exploração exclusiva a genes humanos pela via patentária.

Em resumo, o problema central que o trabalho pretende debater está circunscrito aos seguintes questionamentos:

(a) Podem as informações genéticas encontradas no DNA humano ser objeto de patentes?

(b) Em caso positivo, seria possível compatibilizar o caráter de proteção exclusiva conferido às patentes de genes humanos com a eventual necessidade de se

\footnotetext{
${ }^{3}$ MARQUES, João Paulo Remédio. Patentes de Genes Humanos? Coimbra: Coimbra Editora, 2001.p. 24.

4 "O conteúdo da dignidade da pessoa humana não parece colidir com a patenteabilidade dos genes enquanto substâncias químicas retiradas ou removidas do corpo humano (e que nele não voltem a ser implantadas qua tale) - contanto que sejam objecto de alteração ou modificação -, pois o ser Pessoa Humana depende mais das auto-representações espirituais e culturais - da irredutível transcendência que nos separou dos outros seres que habitam neste planeta -, das ideias, dos valores, das emoções e da personalidade de cada ser humano do que dos caracteres fisiológicos do corpo humano ou dos genes que (também em larguíssima medida) partilhamos com as outras espécies de seres vivos, animais, vegetais e microrganismos" (MARQUES, op. cit., pp. 59-60).
} 
conferir acesso aos possíveis benefícios decorrentes do desenvolvimento científico da pesquisa genética?

(c) Uma eventual reforma legislativa brasileira que permita a patente de genes humanos afrontaria o sistema jurídico nacional? Quais seriam os critérios, a extensão e limites a serem atribuídos a tais patentes?

É a essas questões que se pretende, pela presente proposta de estudo, apontar eventual solução. Para tanto, serão abordadas de forma acessória as potenciais implicações sociais, políticas e econômicas das posições favorável e contrária ao patenteamento de genes - em especial no que concerne ao fomento às atividades de pesquisa $\mathrm{e}$ desenvolvimento da engenharia genética no Brasil.

\subsection{Delimitação do objeto de estudo}

O presente estudo se voltará, portanto, à análise e discussão acerca da necessidade, condições, suficiência e extensão da tutela jurídica a ser conferida pela outorga de direitos de excluir terceiros da exploração de genes humanos pela via patentária.

Ocorre que, como acima mencionado, o fomento à pesquisa e ao desenvolvimento em processos e produtos biotecnológicos tem sido foco de incontáveis debates, notadamente no que se refere aos genes humanos, em razão de implicações que muitas vezes transbordam aspectos meramente jurídicos e econômicos.

A estrita relação que o objeto deste estudo possui com o conceito de vida, direta ou indiretamente, deve implicar numa análise norteada também por princípios éticos, morais e até religiosos, fundada na afirmação de que a apropriação privada dos genes violaria a dignidade humana.

Justamente em virtude da complexidade que envolve o referido tema, é notável certa resistência às evoluções das pesquisas científicas biotecnológicas e consequentemente ao devido estudo sobre a tutela jurídica dos produtos delas originados. Em que pese de reconhecida importância tal discussão, e sem prejuízo deste assunto ser 
retomado em outra oportunidade, o presente estudo não irá se aprofundar em discussões de cunho ético e moral que circundam o tema da patenteabilidade dos genes humanos.

Para tanto, o presente trabalho tem como premissa uma discussão acerca do caráter "inanimado" dos genes, ou seja, que se trata de substancia química não viva, fato este que encontra suporte na biologia, como será demonstrado neste trabalho.

A este respeito, importa destacar que o ser humano possui valor intrínseco e absoluto, de forma que em sua essência é muito mais do que a simples soma de seus genes, não podendo este tipo de proteção implicar apropriação privada do corpo humano por via oblíqua.

Não se pretende aqui simplesmente descartar questionamentos desta natureza, pois eles são de extrema relevância e poderão ser oportunamente analisados de forma mais específica e detalhada; entretanto, não configurarão objeto principal das hipóteses da presente análise, ainda que a reflexão periférica esteja presente.

Assim, por meio da aplicação de conceitos e posicionamentos que envolverão interpretações precipuamente do direito econômico e do direito de propriedade intelectual, bem como da área de biomédicas, pretende-se a obtenção de critérios necessários a orientar a hermenêutica jurídica sobre a patenteabilidade dos genes humanos. 


\section{DESENVOLVIMENTOS BIOTECNOLÓGICOS}

\subsection{A evolução biotecnológica}

A biodiversidade e a genômica podem ser consideradas fontes de vasta quantidade de material biológico, representando assim "insumos", materiais de base cujo tratamento requer um sistema jurídico capaz de permitir e assegurar novos desenvolvimentos em pesquisa e inovação tecnológica.

Destaca-se para os fins do presente plano de pesquisa o campo da biologia molecular, que estuda as funções e as estruturas de aplicação de proteínas e dos ácidos nucleicos. A partir de sua evolução, identificaram-se a natureza do material genético e a forma de produção de proteínas nos seres vivos (além de suas respectivas funções e finalidades biológicas), bem como os processos pelos quais são manipuladas e produzidas as moléculas de DNA recombinante ${ }^{5}$.

Muito embora a biotecnologia tenha evoluído bastante no século passado, apenas nos últimos 20 anos é que avanços relacionados a resultados práticos mais relevantes na área da engenharia genética passaram a ser verificados. A moderna biotecnologia tem propiciado uma sensível mudança nos padrões de pesquisa, desenvolvimento e produção da sociedade atual, podendo-se dizer que os genes estão para a biotecnologia como os combustíveis fósseis estavam para a Revolução Industrial ${ }^{6}$.

A genética surgiu na medicina no início do século XX, quando Archibald Garrod e outros pesquisadores perceberam que as leis mendelianas de hereditariedade eram capazes de explicar a recorrência de certos transtornos familiares.

Gregor Mendel escolhera plantas de ervilha para desenvolver seu estudo sobre a transmissão de fatores genéticos entre gerações. A descoberta das leis da hereditariedade

\footnotetext{
${ }^{5}$ Uma molécula de DNA/RNA que é composta de DNA de diferentes fontes, que não ocorre de forma natural; trata-se, portanto, de qualquer molécula de DNA formada in vitro, ou seja, construída em laboratório por meio da quebra de longas moléculas de DNA em determinados fragmentos e/ou sua união em novas combinações (por meio de técnicas que utilizam bactérias como vetores dos genes a serem utilizados, dentre outros).

${ }^{6}$ RIFKIN, Jeremy. O século da biotecnologia: a valorização dos genes e a reconstrução do mundo. São Paulo: Ed. Makron Books, 1999, passim.
} 
foi possível por terem sido escolhidas espécies de fácil cruzamento e capazes de produzir prole bastante numerosa, além de possibilitar o estudo de conjuntos de características distintas, como cor das flores e formato das sementes - facilmente observáveis e independentes.

Os resultados de seus experimentos eliminaram a teoria da herança por mistura, amplamente aceita à época. A abordagem diferenciada pelo estudo de uma única característica por vez permitiu a proposição dos princípios de hereditariedade, também conhecidos como as "Leis de Mendel":

(a) Primeira Lei de Mendel (Lei da segregação), a qual postula que os dois alelos dados para uma determinada característica em um parental se segregam durante a formação dos gametas, de forma que cada gameta recebe apenas um alelo para cada característica, sendo que durante a fecundação o espermatozoide (que possui um dos alelos) se une a um óvulo (que também possui um dos alelos), restabelecendo um total de 2 cópias do gene para cada característica.

(b) Segunda Lei de Mendel (Lei do arranjo independente), a qual postula que os alelos para diferentes fenótipos segregam independentemente um do outro durante a formação do gameta.

(c) Terceira Lei de Mendel (Lei da distribuição independente), a qual postula que o gene dominante dotado pelos seres híbridos deverá prevalecer em partes sobre o gene recessivo, concluindo que os seres híbridos devem apresentar as características de dominância.

Os "fatores" de Mendel, atualmente denominados genes, "são transportados nos cromossomos, distribuídos durante a formação dos gametas, e novamente reunidos sob novas combinações, nos zigotos, quando ocorre a fecundação. Desta forma, os cromossomos fornecem a base fisica para as leis de Mendel"?.

\footnotetext{
${ }^{7}$ Alberts, Bruce, et al. Fundamentos da Biologia Celular, 3a ed. Porto Alegre: Artmed, 2011, p. 671.
} 
No ano de 1902, Theodor Boveri e Walter Sutton - trabalhando de forma independente - associaram os cromossomos com a hereditariedade, após observação de seu comportamento durante a reprodução sexuada. Posteriormente, Thomas Hunt Morgan demonstrou que os genes estão localizados nos cromossomos.

Logo em seguida, na década de 1940, foi descoberto, a partir de estudos com fungos simples, que a informação genética consistia em instruções para a produção de proteínas. Outro avanço crucial nesta década foi o reconhecimento de que o ácido desoxirribonucleico (DNA) era, provavelmente, o portador dessa informação genética.

E, embora os cromossomos já tivessem sido apontados como base da hereditariedade no início do século XX, foi apenas no início da década de 1950 que o DNA foi examinado pela análise de difração de raios-X, para determinação de sua estrutura tridimensional. A observação de que o DNA era composto por uma fita dupla torcida em uma hélice levou James Watson e Francis Crick a determinar o modelo correto da estrutura de DNA. Assim, logo após o modelo de Watson-Crick da estrutura do DNA ter sido proposto, o potencial para replicação e codificação da informação se tornou aparente.

Stanley Cohen e Herbert Boyer fizeram o primeiro experimento de engenharia genética em 1973. Eles demonstraram que o gene para o RNA ribossomal de um ser eucarionte (sapo) podia ser transferido para um ser procarionte (bactéria), que o expressava. Dessa maneira, foi desenvolvida a primeira molécula de DNA recombinante.

No final da década de 1970, pesquisadores desenvolveram métodos que permitiram que a sequência de nucleotídeos de qualquer fragmento de DNA purificado fosse determinada de forma simples e rápida. Vários esquemas de sequenciamento foram desenvolvidos, mas o mais utilizado é o sequenciamento de DNA didesoxi, um método com base na síntese de DNA realizada in vitro na presença de trifosfatos de didesoxirribonucleosídeo terminadores de cadeia.

Porém, foi apenas em 1989 que um gene humano veio a ser sequenciado pela primeira vez: o gene $C F T R$, o qual codifica uma proteína que funciona como um canal de cloro e que regula o fluxo de outros íons pela superfície apical de células epiteliais. Este, 
quando apresenta uma mutação patogênica, é responsável pela doença fibrose cística ou mucoviscidose.

Mais recentemente, durante os anos de 1990 a 2003, foi realizado o mapeamento do genoma humano pelo Projeto Genoma Humano (PGH), com escopo internacional, sendo este um dos mais importantes eventos para os fins do presente estudo. Como será visto ao longo deste trabalho, o PGH possibilitou a identificação de toda a sequência de bases nitrogenadas que compõem a cadeia de DNA e permitiu a identificação dos respectivos genes, sendo estes considerados pilares do desenvolvimento biotecnológico na área da engenharia genética.

Está claro que a obtenção da sequência de um gene ou de um genoma inteiro é apenas o início. O grande desafio é observar uma sequência de nucleotídeos e determinar onde um gene inicia e termina, e quais partes são importantes para regular sua atividade. Ainda assim, não é necessariamente aparente qual o seu papel na fisiologia de um organismo. Para isso, os pesquisadores precisam manipular cada gene mais diretamente, pois o sequenciamento por si só é apenas uma grande biblioteca de informações que devem ainda ser estudadas e entendidas. Esta catalogação de toda a informação genética humana é, portanto, apenas o ponto de partida para os desenvolvimentos possíveis a serem alcançados pela engenharia genética, e - ato contínuo - da busca da tutela jurídica mais adequada à sua promoção.

\subsection{Conceitos preliminares de biologia molecular e genética}

Dando-se continuidade à análise preliminar relacionada aos aspectos biológicos relevantes ao presente estudo, passam-se a apresentar conceitos de biologia molecular e genética fundamentais às discussões jurídicas realizadas nos próximos Capítulos, especialmente no que tange ao cumprimento dos requisitos autorizadores à concessão da tutela patentária.

Um primeiro aspecto a ser considerado é a conceituação de materiais biológicos naturais, suas características e funções. Em seguida, buscar-se-á distingui-los dos materiais biológicos não-naturais, ou seja, aqueles que não ocorrem espontaneamente na natureza. 
Ainda, serão apresentadas noções relativas à diferenciação entre matérias biológicas vivas e não-vivas; tal distinção possui consequências jurídicas importantes ao presente estudo: muito embora para algumas jurisdições não seja critério determinante à exclusão da proteção patentária, em outras o objeto biotecnológico vivo poderá ser causa direta desta impossibilidade de proteção.

Por fim, serão ainda abordados neste Capítulo os métodos utilizados para se obter versões do DNA naturalmente encontrado, originadas da intervenção humana, e que formam a base da engenharia genética aplicada para fins dos mais diversos, inclusive e especialmente relacionados à saúde.

Isso porque, como indicado anteriormente, não são as sequências de DNA encontradas nos organismos de seres vivos que são alvo de reivindicações de titularidade patentária em todo o mundo: os produtos isolados e purificados obtidos pelas mais variadas espécies de intervenção humana na forma em que uma sequência de DNA é encontrada em sua forma nativa, ou mesmo a síntese química laboratorial de genes, é que são as substâncias objeto das reivindicações de patentes aqui tratadas.

A partir daí será possível a correta identificação da natureza biológica e jurídica dos genes humanos enquanto matérias eventualmente sujeitas à proteção patentária e como se inserem no contexto das inovações biotecnológicas, permitindo-se, assim, que seja identificada e atribuída a tutela jurídica mais adequada.

\subsubsection{Material biológico: conceito e classificação; materiais biológicos vivos e não-vivos; materiais biológicos naturais e não-naturais}

Segundo o texto da Convenção sobre Diversidade Biológica, pode ser considerado material biológico "todo material de origem vegetal, animal, microbiana ou outra que contenha unidades funcionais de hereditariedade" ${ }^{\nexists /}$ eu capaz de se reproduzir ou ser reproduzido em um sistema biológico. Esta definição acompanha o conceito da Organização da Cooperação para o Desenvolvimento Econômico (OCDE), segundo o qual

\footnotetext{
${ }^{8}$ Cf. definição dada pelo artigo 2 da Convenção sobre Diversidade Biológica (CDB), que será objeto de análise no Capítulo 5.2.4.
} 
material biológico é aquele que contiver "informação genética e seja capaz de auto reprodução ou de ser reproduzido em um sistema biológico"”.

Para SILVEIRA, DAL POZ e ASSAD, os desenvolvimentos biotecnológicos podem ser caracterizados como um "bloco robusto que combina diferentes protocolos de pesquisa já existentes com novos procedimentos científicos derivados de diferentes disciplinas, tais como bioquímica e biologia molecular. Isso permite um grande potencial para novas combinações com paradigmas existentes, como o da ciência da computação. Isso está relacionado ao processo de inovação, que é a combinação de diferentes peças do conhecimento, onde cada ação é um building block."10

Desta forma, material biológico inclui não apenas aqueles organismos compostos por células, mas também a própria célula e os seus componentes. As formas mais simples de vida são as células solitárias; cada animal, planta, ou fungo pode ser entendido como uma vasta colônia de células individuais que realizam funções especializadas coordenadas por complicados sistemas de condução. Sob esta perspectiva, pode-se afirmar que as células são as unidades básicas da vida. O mesmo não se pode dizer, contudo, dos elementos/compostos químicos que as formam; estes, por si só, não têm condições de se reproduzir e/ou produzir um novo organismo vivo. Muito embora existam entendimentos no sentido de que os componentes integrantes de uma matéria viva também devam ser considerados como tal, em verdade eles possuem natureza de compostos químicos tãosomente. Sustenta MARQUES que os genes estariam inseridos nesta classificação, conforme se pode depreender do excerto a seguir:

\footnotetext{
"Dado que o corpo humano e o feto são organismos vivos, há quem questione se os 'componentes das coisas vivas' podem igualmente ser considerados como seres vivos. Em oposição, outros sustentam que: manter 'tal perspectiva leva, não raras vezes, que a cessação da 'vida' seja definida num plano molecular mais restrito'. Assim, a maioria dos autores concorda que a molécula de ADNapesar de sua diversidade e complexidade - é uma substância química 'morta'. Se o gene for assim entendido como um composto químico, não poderá ele ser visto como matéria viva, mas, ao invés, meramente como uma 'coisa morta', que
}

\footnotetext{
${ }^{9}$ Cf. Working Party on Biotechnology, da OCDE, fevereiro de 2001.

${ }^{10}$ SILVEIRA, José Maria Jardim da; DAL POZ, Maria Ester Soares; ASSAD, Ana Lucia. Biotecnologia e recursos genéticos: desafios e oportunidades para o Brasil. Campinas: Instituto de Economia, Universidade Estadual de Campinas e FINEP, 2004, p. 208.
} 
pode ser objecto de patente, tal como a invenção do caminho de ferro ou da batedeira de ovos." 11

Vê-se, assim, que podem ser encontradas na natureza matérias biológicas vivas e matérias biológicas não-vivas, sendo estas caracterizadas como meros compostos químicos. Neste contexto, o DNA individualmente considerado deve ser entendido como um composto físico-químico (matéria não-viva), porquanto neste contexto ele deixaria de ser considerado parte do ser vivo, incapaz de reprodução, ou seja, de gerar um novo organismo.

Como será visto de modo detalhado a seguir, os genes são formados no corpo humano por sequencias determinadas de DNA. Essas sequências, em última análise formadas por nucleotídeos, são responsáveis pela informação contida em cada um dos genes.

As possibilidades de combinações possíveis de sequências de DNA potencialmente formadoras de genes em qualquer organismo são incontáveis e sua ocorrência espontânea resulta na evolução de espécies - originada de mutações verificadas casualmente ao longo de milhares de anos. Atualmente, contudo, isso pode ser obtido por meio da intervenção humana, constituindo-se este um dos vieses do campo de atuação verificado no âmbito da engenharia genética.

Essa participação ativa do homem em processos biológicos, capaz de originar matérias biológicas não previamente existentes na natureza, pode inclusive ter como consequência a criação de novas matérias biológicas, as chamadas matérias biológicas nãonaturais - dentre os quais se inserem os OGMs, por exemplo.

Tal distinção é de extrema importância, porquanto tais materiais possuem uma característica distintiva importante em relação àqueles que ocorrem naturalmente: são indubitavelmente produtos biológicos novos, haja vista que não podem ser identificados de forma espontânea na natureza, sem que haja a intervenção técnica do homem, determinante à sua criação.

\footnotetext{
${ }^{11}$ MARQUES, op. cit., p. 72.
} 
Os materiais biológicos não-naturais possuem, portanto, um caráter de novidade absoluta - entendida em seu sentido objetivo, pela noção tradicional de patentes -, de modo que sua eventual proteção poderia se equiparar àquela conferida às invenções mecânicas (de forma ampla), caso obviamente os demais requisitos autorizadores de tal proteção sejam verificados.

Esta situação, quando ocorre, é capaz de configurar um passo inventivo relevante e autêntico, que difere daquelas versões originadas da intervenção humana dos materiais biológicos naturalmente ocorrentes - porquanto esses, ao contrário, apresentarão carga informacional genética equivalente à verificada no material biológico natural.

Feita esta distinção, e, tendo em vista que suas características distintas conferem maior facilidade na acomodação de sua proteção ao sistema tradicional de patentes, importa esclarecer que os materiais biológicos não-naturais (i.e. pesquisas científicas objetivando a modificação genética de organismos que envolvam, por exemplo, a clonagem e/ou a realização de melhoramentos/modificações genéticas) não integram objeto do presente estudo, pois as sequencias de DNA individualmente consideradas, embora sejam matérias biológicas não vivas, obviamente são naturais, como já anteriormente apresentado.

O campo de estudo dos genes humanos destacados de seu ambiente natural para fins de aplicações práticas pelo homem - que não impliquem técnicas de engenharia genética que altere sua estrutura biológica - constitui, portanto, área de maior discussão ${ }^{12}$ no que tange à sua novidade, e, consequentemente, à existência de motivos plausíveis que justifiquem a legitimidade de sua proteção pela via patentária.

\subsubsection{Genes e o ácido desoxirribonucleico (DNA)}

Os genes podem ser entendidos como unidades biológicas capazes de definir as características e a forma de funcionamento de um organismo. Os genes descrevem a estrutura e as propriedades químicas instruídas pelas moléculas de DNA em particular

\footnotetext{
${ }^{12}$ Obviamente tal afirmação deve ser feita sem se descuidar, contudo, de outros âmbitos de discussão bastante controversos - em que se inserem as matérias biológicas vivas não naturais, em especial de caráter ético, moral e religioso, que também por via reflexa não integram o presente estudo, conforme já se teve a oportunidade de esclarecer no Capítulo 1.3.
} 
neles contidas, de forma a determinar a expressão gênica do organismo, funcionando como um diagrama para a produção de proteínas.

Sua estrutura é identificada por longas moléculas de DNA, composição química tangível contida no cromossomo. A molécula de DNA consiste em duas longas cadeias polinucleotídicas, sendo que cada uma delas é composta por 4 tipos de subunidades de nucleotídeos (estes, por sua vez, ligados às bases nitrogenadas adenina, timina, citosina e guanina, identificadas por suas iniciais "A", “T", "C" e "G", respectivamente).

As cadeias polinucleotídicas da dupla hélice são ligadas por pontes de hidrogênio, ocorrendo um pareamento complementar entre a sequência das bases de nucleotídeos descritas em cada uma dessas "fitas" de DNA. É justamente esta ordem/sequência de nucleotídeos identificadas ao longo da fita de DNA que determina os genes.

Cada gene é responsável pela produção de moléculas de RNA e estes - por sua vez - são responsáveis pela tradução da sequência em aminoácidos que, finalmente, concluirão pela produção das proteínas, sendo estas consideradas as principais macromoléculas constituintes das células.

A produção de proteínas, portanto, é coordenada pela sequência indicada na fita de DNA contida no gene, sendo este o "molde" que irá conduzir à síntese proteica a partir de fitas de ácido ribonucleico (RNA) dele originadas. Tal procedimento destinado à síntese de proteínas é realizado, basicamente, mediante a ocorrência de duas etapas distintas e sucessivas: a transcrição e a tradução.

Primeiramente, a sequência do gene é transcrita em RNA, do qual resulta o preRNA, que contém tanto éxons quanto íntrons; a seguir, os íntrons são removidos (processo denominado splicing), produzindo o RNA mensageiro (mRNA). Este, por sua vez, passa por uma série de etapas adicionais antes de seguir ao citoplasma das células, onde traduzido na proteína codificada por meio de grupos compostos por 3 nucleotídeos (códons), cada um deles correspondendo a um aminoácido.

Cada proteína é composta de uma ou mais cadeias lineares de aminoácidos ligados por ligações peptídicas em uma sequência específica. A cadeia de aminoácidos é dobrada 
em uma forma tridimensional que é única e determina sua função. As diversas funções realizadas pelas proteínas, como catalisar a formação ou quebra de ligações covalentes, prover suporte mecânico para células e tecidos, transportar moléculas e íons, por exemplo, devem-se ao grande número de conformações que elas são capazes de adotar.

Os genes referem-se, em última análise, a unidades de informação para a codificação de proteínas que são fundamentais à vida, mas que não poderiam se confundir com a própria vida. E, muito embora atualmente seja conhecida a forma pela qual tais informações contidas nos genes são codificadas em proteínas, muitas delas não possuem ainda funções conhecidas - sendo já conhecido que os genes possuem sequências de DNA com funções biológicas já conhecidas e definidas na síntese proteica (os éxons) e segmentos que aparentemente não possuem qualquer função biológica associada (os íntrons).

Assim, o estudo do funcionamento dos genes (considerados isoladamente ou em conjunto) permite determinar as funções e importância biomoleculares de cada um e, a partir daí, eventuais aplicações de cada um destes fragmentos que compõem a fita do DNA de qualquer organismo vivo. Caso um determinado gene possuísse finalidade única e exclusiva, talvez não seriam tão grandes as implicações para os fins do presente estudo; entretanto, as sequências de DNA contêm informações potencialmente geradoras de inúmeras aplicações, havendo diversas sequências cujas funções biológicas sequer são conhecidas.

Por tais motivos, as sequências de DNA não devem ser vistas como apenas moléculas, mas também como informação. Esta natureza híbrida de que se revestem os genes pode trazer problemas no estabelecimento de regras consistentes na aplicação da proteção da propriedade intelectual sobre referidos materiais biológicos, uma vez que o escopo da patente torna-se de difícil caracterização, especialmente porque existe a possibilidade de que diversos resultados sejam obtidos a partir de um mesmo gene.

Neste contexto, pode-se entender que referida forma de proteção dependeria da aplicação prática ou utilidade que vier a ser declarada, fato este que reforçaria o caráter informacional do gene como preponderante. Desta feita, importante será conceituar e correlacionar a "utilidade" e a "aplicação industrial" como critérios determinantes de 
patenteabilidade, bem como avaliar o papel daquele requisito na avaliação de mérito de uma reivindicação de patente genética, assuntos estes que serão objeto de Capítulo específico.

\subsubsection{Informação Genética: sequenciamento e genoma}

Genoma refere-se ao código genético dotado de toda a informação hereditária de um organismo, ou seja, refere-se a "toda biblioteca de informação genética"13 contida no DNA das células. O sequenciamento genético refere-se ao processo pelo qual a ordem precisa dos nucleotídeos no gene (ou, em última análise, no segmento de DNA) é determinada.

É a partir do mapeamento da sequência das bases de nucleotídeos que compõem o DNA que se torna possível identificar o conjunto genético de cada espécie (genoma) ou determinados "trechos" específicos - os genes - que orientam a fabricação ou inibição de proteínas específicas.

Diante deste contexto, está claro que o sequenciamento do DNA humano deve ser considerado como ponto de partida para todo e qualquer desenvolvimento biotecnológico que envolva produtos e/ou processos originados de genes humanos por meio da aplicação da engenharia genética.

O PGH teve como objetivo principal realizar o sequenciamento dos 23 pares de cromossomos do ser humano, tendo seu resultado parcial publicado em 2004, a fim de tornar "possivel a identificação de todos os seus genes, a determinação do grau de variação desses genes em diferentes populações e, por fim, a identificação do processo através do qual essa variação contribui para a saúde e as doenças" ${ }^{14}$.

Além do sequenciamento completo, o PGH tinha outros 3 objetivos, a saber: o desenvolvimento da tecnologia para o próprio mapeamento e sequenciamento de genes, a

\footnotetext{
${ }^{13}$ NUSSBAUM, Robert L. et al. Thompson \& Thompson, Genética Médica, $7^{\mathrm{a}}$ ed. Rio de Janeiro: Elsevier, 2008, p.5.

${ }^{14}$ NUSSBAUM, op. cit., p.1.
} 
ampliação da condução deste projeto para outros 5 modelos de organismos, e a investigação das implicações éticas, socioeconômicas e legais desta empreitada.

Devido ao seu alcance de larga escala, o consórcio responsável pelo PGH era realizado por um conjunto de 20 centros localizados em diferentes países (Estados Unidos, Grã-Bretanha, França, Japão, Alemanha e China), com extensiva colaboração em termos de estratégia, metodologia e análise entre eles ${ }^{15}$.

Uma vez concluída a fase de catalogação, que listou a ordem nucleotídica de todo o DNA humano, o desafio seguinte passou a ser a identificação e contagem dos genes humanos. Para tanto, foram desenvolvidas técnicas que se prestavam a buscar e identificar os genes contidos nas longas fitas de DNA listadas. Dentre as técnicas disponíveis destacavam-se as seguintes: (a) a busca por fases abertas de leituras (ORF), busca por sequências de splicing; (c) homologia com genes de outros organismos; (d) a análise dos marcadores de sequências expressas.

Por meio da busca de sinais ORF, pretende-se identificar os códons início e de parada dos genes pela leitura aleatória de fases abertas de nucleotídeos. De acordo com este mecanismo, tem-se que a identificação de uma sequência de nucleotídeos contínua que codifique mais de 100 aminoácidos, poderá configurar a primeira etapa na identificação de um bom candidato para um gene presumível.

Entretanto, este processo de identificação é complicado no genoma de seres eucariontes pela presença de grandes sequencias intrônicas que interrompem as porções codificantes dos genes.

Assim, outras características devem ser também buscadas para se identificar genes no DNA eucariótico, como é caso das sequências de splicing, que sinalizam uma delimitação entre um íntron e um éxon ou sequências de DNA regulatórias distintas que se encontrem antes de um gene.

\footnotetext{
${ }^{15}$ Em 1999, a empresa Celera anunciou sua intenção em realizar o sequenciamento do genoma humano de forma privada, em apenas dois anos com uma nova metodologia (shotgun). Entretanto, a "corrida" pelo sequenciamento não foi justa, já que o grupo Celera utilizou informação já publicada pelo Consórcio.
} 
Além disso, um importante mecanismo utilizado para a identificação de genes é a homologia com outros organismos. Por exemplo, se uma ORF presumível como gene for altamente conservada em vários genomas diferentes, é muito provável que codifique uma proteína, mesmo que o gene que a contenha ainda não tenha sido identificado.

Por fim, uma estratégia complementar para se verificar as regiões codificadoras no genoma envolve determinar experimentalmente os genes que são expressos, o que é obtido por meio do isolamento e conversão do mRNA obtido nas células em DNA complementar (cDNA): tendo-se em vista que os mRNAs são produzidos pela transcrição de genes codificantes para proteínas, os cDNAs deles originados deverá representar as sequências de todos os genes que foram expressas nas células em que os mRNAs foram obtidos.

Os fragmentos desses cDNAs, que são conhecidos como marcadores de sequências expressas (ou, Expressed Sequence Tags - ESTs) são então sequenciados e comparados com as sequencias de DNA contidos no genoma para localizar o gene que contém cada uma delas.

Os ESTs são bastante "famosos" na discussão da patenteabilidade de genes humanos pois, em virtude de sua composição - em especial por conter a informação do gene ao qual integram - foi objeto de incontáveis reivindicações de patentes, cujas proteções eram originalmente concedidas por meio de sua simples descrição, desacompanhada de qualquer relato sobre sua(s) utilidade(s) prática(s).

Com a publicação final do PGH em 2004, os pesquisadores chegaram a algumas conclusões importantes, dentre as quais destacam-se as seguintes:

(a) A primeira característica é o quão pouco dele - somente uma pequena porcentagem - codifica proteínas, RNAs estruturais e RNAs catalíticos.

(b) Uma segunda característica é a imensa média de tamanho gênico de quase 27.000 pares de nucleotídeos, ou seja, os éxons codificantes de proteínas são relativamente curtos. 
(c) Outra característica surpreendente é o pequeno número de genes, (aproximadamente 25.000), quantidade muito próxima daquela existente em animais multicelulares mais simples, como a Drosophila, que possui 14.000 genes.

(d) Finalmente, a sequência de nucleotídeos se encontra em aparente "desordem": a maior parte do genoma é constituída de sequências não codificantes, alternadas de maneira "aleatória" com repetições de sequências nucleotídeas curtas (repetidas por longas regiões), sequências gênicas (íntrons e éxons), e, ainda, sequências únicas que incluem elementos regulatórios gênicos, assim como sequências cujas funções não são conhecidas.

Cada um dos seres humanos carrega em seu genoma um conjunto único e característico de variações nas sequências de nucleotídeos. Em regiões específicas, essas variações podem ser comuns e inócuas, de tal forma que é provável que duas pessoas escolhidas ao acaso sejam distintas para essa posição. Nesses casos, quando duas ou mais sequências variantes coexistem em uma população e são relativamente comuns $(>1 \%)$, elas são chamadas de polimorfismo. As variações mais comuns correspondem a substituição de nucleotídeo único (SNPs).

Tipicamente, qualquer par de seres humanos difere em torno de $0,1 \%$ de suas sequências nucleotídicas, resultando em aproximadamente 3 milhões de diferenças entre uma pessoa e outra. Esses SNPs podem ser usados como marcadores ${ }^{16}$ para a construção de mapas genéticos ou para o direcionamento de busca de mutações patogênicas, o que também originou reivindicações patentárias, que, durante determinado período, foram reconhecidas em algumas jurisdições - assim como acontecia com os $\operatorname{ESTs}^{17}$.

Ainda, os SNPs humanos tendem a ser herdados em grandes blocos de haplótipos segmentos do genoma que foram herdados intactos a partir de ancestrais distantes e que na maioria dos indivíduos não foram ainda separados pela recombinação meiótica. Assim, o tamanho destes blocos haplótipos nos permite inferir sobre nossa história evolutiva.

\footnotetext{
16 “As SNP constituem, igualmente, marcadores genéticos, apresentando, tal-qualmente as EST, sequências parciais de genes. Porém, e ao invés, encontram-se essencialmente localizados no exterior dos genes, ou seja, na porção do ADN não codificante - cuja função é, também, pouco conhecida - corresponde a mais de 90\% da totalidade dos genomas (humano, animal ou vegetal).” (MARQUES, op. cit., p. 12, nota de rodapé.)

${ }^{17}$ A questão dos ESTs e dos SNPs, e como se inseriam no âmbito das reivindicações patentárias nos EUA será tratada no Capítulo 5.3.
} 
Independentemente da forma em que os genes são buscados e ou identificados no genoma humano, até porque atualmente se pode dizer que constituem atividades rotineiras de laboratório ${ }^{18}$, fato é que as funções e formas de interações dos genes para a formação do ser humano configuram o aspecto mais interessante a ser analisado. Ao mesmo tempo, existe, neste particular, um vasto campo a ser decifrado, o que abre um leque para novos desenvolvimentos biotecnológicos com práticas aplicações técnicas e potenciais benefícios à sociedade.

A este respeito, importa mencionar que - de todos os genes que tiveram sua sequência determinada - aproximadamente apenas deles $50 \%$ codificam para proteínas de função conhecida. Ademais, há questões relativas ao splicing alternativo (em que uma mesma célula produz uma série de proteínas relacionadas, porém distintas, a partir de um único gene), ao papel do micro RNA (que recentemente descobriu-se ser responsável por regular $1 / 3$ de todos os genes humanos), e ao fato de que aparentemente apenas $1,5 \%$ de todo o genoma humano codifica para proteínas, dentre outros.

Neste contexto, os desdobramentos que têm se originado a partir dessas pesquisas devem ser entendidos como um dos principais campos da biotecnologia, o que justifica a importância do presente estudo.

\subsubsection{Purificação e isolamento de genes}

A molécula de DNA nativo, existente em um cromossomo, "existe na cromatina como um complexo com uma família de proteínas cromossômicas básicas denominadas histonas, e com um grupo heterogêneo de proteínas não-histonas que são muito menos bem caracterizadas, mas que parecem ser críticas para o estabelecimento de um ambiente adequado para assegurar o comportamento cromossômico normal e a expressão apropriada do gene ${ }^{, 19}$ em um organismo.

\footnotetext{
${ }^{18}$ Pode-se dizer que ao longo do tempo as técnicas de sequenciamento de DNA se tornaram totalmente automatizadas e computadorizadas, de modo que a determinação da ordem dos nucleotídeos nos organismos deixou de ser um projeto de tese de doutorado para ser uma tarefa rotina de laboratório.

${ }^{19}$ NUSSBAUM, op. cit., p.8.
} 
Entretanto, o DNA neste estado natural não se mostra útil na busca dos desenvolvimentos biotecnológicos a partir dele. Para que isso ocorra, devem eles ser extraídos do ambiente celular, o que se dá por meio de técnicas laboratoriais.

Assim, o DNA isolado ou purificado refere-se ao DNA extraído de seu ambiente natural e que passou por um processo posterior de extração e separação do material estritamente genético de outros componentes que naturalmente o acompanham, a fim de se obter a sequência de DNA de interesse de forma "limpa", para que assim sejam viabilizadas as utilidades práticas adicionais no âmbito da biotecnologia.

A clonagem molecular e a Reação em Cadeia da Polimerase (PCR) são revoluções tecnológicas que solucionaram o problema da obtenção do DNA/RNA em quantidade e pureza suficientes para se permitir análise detalhada, possibilitando a realização das pesquisas em desenvolvimento biotecnológico.

A finalidade da clonagem molecular é o isolamento de um gene em particular em grandes quantidades para maiores estudos. Este resultado é obtido a partir da transferência de uma sequência de DNA para um microrganismo. Este por sua vez, cresce em cultura, de modo a reproduzir a sequência de DNA juntamente com seu próprio DNA. Cada microrganismo individual é chamado de clone, e uma coleção de clones é chamada de biblioteca.

A PCR é uma alternativa à clonagem para gerar uma quantidade essencialmente ilimitada de uma sequência de interesse. A PCR é uma amplificação enzimática de um fragmento de DNA (o alvo) localizado entre dois iniciadores (primers). Com a síntese repetida do DNA entre dois primers, este segmento é específica e seletivamente amplificado de modo exponencial. É uma técnica sensível, mais rápida e econômica, que requer menos amostra na comparação com qualquer outro método de análise de DNA.

Os genes isolados e purificados são resultado de processos técnicos ${ }^{20}$ que os identificaram, caracterizaram e multiplicaram fora do corpo humano, que somente o ser

\footnotetext{
${ }^{20}$ Em virtude do rápido desenvolvimento de tecnologias de computação, métodos automáticos de extração de DNA podem ser atualmente utilizados, sendo esta forma de extração de DNA benéfica por inúmeras razões,
} 
humano seria capaz de executar, e que a natureza não pode realizar por si mesma. Elas são originadas exclusivamente da intervenção humana e somente podem ser produzidas sob determinadas condições e em ambientes controlados.

Do ponto de vista estritamente técnico, as sequências de DNA isoladas e purificadas não existem, não são produto e tampouco são encontradas na natureza. O DNA isolado e/ou purificado é, portanto, uma molécula distinta com características físicas e funcionalidades diferentes do polímero que existe naturalmente, sendo tais diferenças relacionadas à mudança nas ligações químicas do DNA isolado, além da separação de outros elementos a ele vinculados. Em outras palavras: as intervenções humanas envolvendo a extração, purificação e isolamento de sequências de DNA de organismos vivos dão origem a um material biológico diverso daquele existente em sua forma natural, pela separação de outros materiais/impurezas existentes na célula.

A reforçar este argumento, importa mencionar, ainda, que o material biológico naturalmente verificado não pode ser usado em aplicações biotecnológicas, ao contrário do DNA nativo. O mesmo ocorre com o DNA sintetizado em laboratório, que será tratado a seguir.

De outro lado, contudo, muito embora não seja possível a obtenção de DNA isolado/purificado espontaneamente, a "cadeia" desta sequência de DNA é exatamente a mesma encontrada na natureza, de modo que a sequência de nucleotídeos apresentada em ambos os casos - e, consequentemente, os respectivos conteúdos informacionais - não são modificados.

Deste modo, uma detalhada análise acerca desses processos de obtenção de sequências de DNA é de fundamental importância, a fim de se realizar "teste" de patenteabilidade de produtos e processos biotecnológicos.

inclusive - mas sem se limitar - redução de tempo de trabalho e de custos com recursos humanos, aumento da segurança no trabalho. 


\subsubsection{Produção de materiais biológicos de modo sintético}

As moléculas de DNA também podem ser sintetizadas em laboratório. Uma forma de obtenção de versões laboratoriais de sequências de DNA resulta no chamado DNA complementar (cDNA). O cDNA é sintetizado a partir do mRNA, de forma análoga à transcrição. E, sendo sintetizado a partir do mRNA e enzimas de transcriptase reversa, o cDNA contém apenas as sequências de éxons existentes na sequência nativa que originou o mRNA que lhe der origem.

O cDNA é assim uma versão editada do gene, sendo excluídas todas as regiões que não possuem função conhecida (íntrons). Além disso, possui a sequência cauda poliA, que só é encontrada no mRNA (e não no DNA nativo). A adição da cauda poliA no mRNA final permite a estabilidade deste, além de figurar como traço distintivo estrutural importante em relação ao DNA naturalmente ocorrente.

Atualmente entende-se que o resultado obtido na síntese do cDNA por meio de técnicas laboratoriais seria inquestionavelmente novo ${ }^{21}$, pois contém uma sequência de bases única originada da intervenção humana e que não se encontra na natureza espontaneamente.

Em que pese o cDNA seja originado pela intervenção humana e possua estrutura física claramente diversa daquela apresentadas pelo DNA correspondente encontrado no corpo humano, a informação genética carregada pelos segmentos de DNA assim produzidos parece permanecer inalterada em relação àquela espontaneamente encontrada na natureza - assim como ocorre com as sequências de DNA isoladas e purificadas de seu ambiente natural, como já se teve a oportunidade de demonstrar.

O mecanismo de produção do cDNA, muito embora possa contar com a exclusão das regiões que não codificam qualquer função biológica, não resulta em qualquer diferencial funcional em relação àquela encontrada na natureza. Isso quer dizer, em última instância, que o material biológico - tanto do DNA isolado/purificado, quanto do cDNA -

\footnotetext{
${ }^{21}$ Recente decisão Suprema Corte Americana no caso Association for Molecular Pathology v. Myriad Genetics, datada de 13 de junho de 2013, alterou entendimento até então prevalecente no sentido de que a simples intervenção humana para isolamento de genes não o tornaria um produto patenteável; entretanto, considerou que o cDNA poderia ser patenteável, pois não ocorreria espontaneamente na natureza.
} 
continuaria sendo exatamente igual àquele encontrado nas células dos organismos na natureza, no que diz respeito às funções biológicas por ele codificadas.

\subsubsection{Métodos diagnósticos}

Ao longo de milhares de anos, alterações genéticas espontâneas vêm sendo responsáveis pela diversidade de espécies e sua evolução, que via de regra ocorre de modo progressivo $^{22}$. De outro lado, são também responsáveis por más-formações, cânceres e doenças congênitas que acometem estes mesmos organismos, podendo ser originadas de falhas nos mecanismos normais de duplicação e manutenção do DNA.

A mutação é definida como uma mudança na sequência de nucleotídeos (representadas pela substituição de bases) ou no arranjo do DNA. As mutações podem ser classificadas em três categorias, a saber: (a) mutações que afetam o número de cromossomos na célula (mutações genômicas); (b) mutações que alteram a estrutura de cromossômicos específicos (mutações cromossômicas); e (c) mutações que alteram genes individualmente (mutações gênicas).

Todos os três tipos de mutação ocorrem em alta frequência em diferentes tipos de células. Se ocorrer no DNA das células germinativas, a mutação pode ser passada para gerações futuras. Em contraste, se ocorrer em células somáticas, em apenas um subgrupo de células de certos tecidos, pode resultar em situações de câncer.

Mutações na sequência podem alterar tanto a estrutura quanto a função da proteína resultante. O sequenciamento de DNA usado em métodos diagnósticos clínicos determina se um gene contém mutações associadas a uma doença em particular, ou ao risco de uma doença.

\footnotetext{
${ }^{22}$ Uma análise comparativa de genomas de espécies pode rastrear suas relações evolutivas e demonstrar momentos de divisão das diferentes linhagens, sendo certo que algumas informações genéticas têm sido mantidas, ou seja, conservadas desde o início da vida. Sobre tal fato, MARQUES assevera ser “(...) um facto que, quanto maior for a afinidade entre dois organismos no sentido evolutivo da expressão, maior será a semelhança entre as sequências de ADN desses organismos, bem como entre os seus genes. Os seres humanos não constituem uma excepção e, consequentemente, partilham uma maior ou menor parte dos seus genes com outros seres vivos" (MARQUES, op. cit., p. 93).
} 
O sequenciamento de genes é usado em testes diagnósticos, como os testes desenvolvidos pela empresa americana Myriad Genetics, para determinar se um gene contém mutações naturais, que podem estar associadas à propensão ao desenvolvimento de uma doença em particular.

\subsubsection{Engenharia genética como desenvolvimento biotecnológico}

Os métodos de análise e manipulação do DNA, RNA e proteínas permitem o estudo dos genes e das informações nele contidas, sendo esta a base para o desenvolvimento das inovações biotecnológicas. Como visto, foi no início da década de 1970 que pela primeira vez foi possível se isolar um fragmento do DNA, fato este que possibilitou a sua replicação em ambiente laboratorial, para posterior reinserção nos organismos de origem.

A partir daí, teve início a tecnologia do DNA recombinante, ou seja, da engenharia genética. Por meio da utilização de referida técnica, tornou-se possível não apenas a obtenção dos genes isolados/purificados de seus ambientes naturais para que pudessem ter outras aplicações, mas também a combinação de genes cuja ocorrência na natureza poderia ser concebível mediante eventos randômicos e ao longo de anos - ou mesmo daqueles que a princípio sequer seriam capazes de ocorrer naturalmente (sendo este segundo ramo excluído do objeto do presente estudo, conforme já anteriormente delimitado).

Mesmo com a sequência do genoma humano concluída e disponível, muitas questões continuam desafiadoras: os estudos de regulação gênica, especialmente sobre a informação contida no DNA regulatório não codificante; os estudos sobre splicing alternativo, pois permite que a célula produza uma série de proteínas relacionadas a partir de um único gene; e os estudos dos microRNAs provavelmente trarão muitas respostas a uma série de dúvidas levantadas pelo PGH.

Em todo caso, já é possível delinear as principais categorias de desenvolvimentos que podem ser obtidos através da engenharia genética abrangidas pelo presente estudo: (a) produtos relacionados à matéria biológica de per se; (b) processos para a obtenção de matéria biológica; (c) inovações tecnológicas que envolvam o uso de material biológico (produtos industriais obtidos por processo utilizando matéria biológica e produtos 
industriais utilizando a matéria biológica); e (d) novos usos de matéria biológica conhecida.

\subsection{Materiais biológicos como instrumentos de pesquisa para invenções subordinadas}

Ante o que se pôde depreender dos conceitos trazidos - ainda que de forma perfunctória - ao longo deste Capítulo, pode-se dizer que umas das principais características dos genes reside no seu conteúdo informacional, sendo este um elemento de base potencialmente útil para diversas "invenções" biotecnológicas. Mais que isso, esta matéria-prima não possui substituto.

E como se sabe, atualmente o genoma humano já foi totalmente sequenciado, de modo que toda a informação genética de base necessária ao desenvolvimento subsequente da engenharia genética, baseado unicamente no conteúdo informacional dos genes humanos, já estaria disponível.

Os genes entendidos como composições bioquímicas existentes na natureza, em princípio, não poderiam ser objeto de apropriação privada. Entretanto, apesar de ser o DNA um composto químico existente na natureza, os genes em sua forma pura (isolados/purificados ou produzidos sinteticamente) possuem características materiais distintivas originadas de uma intervenção humana.

São justamente os genes "puros" - dissociados desses outros elementos aos quais estão ligados em sua forma natural - que vêm sendo objeto de discussão sobre patenteabilidade em diversas jurisdições, justamente por possuem aplicabilidades e utilidades práticas que o DNA humano, em sua forma natural, não apresenta.

Assim sendo, uma das maiores dificuldades reside no fato de que a potencial concessão de uma patente - se entendida em seu conceito tradicional - não apenas protegerá as reivindicações fundadas em funções especificas expressamente descritas: outras inovações, tratamentos, identificação de outras funções/finalidades que venham (ou 
poderiam vir a ser) atribuídas a outros cientistas futuramente poderão estar englobadas por tal reivindicação anterior.

Neste sentido, as patentes poderiam enfraquecer a criatividade social dos cientistas por inibir a comunicação entre eles, imprescindível para o processo de criação científica, como já se pôde verificar no Capítulo 3.1. Nesta perspectiva, a privatização do conhecimento biotecnológico poderia ocasionar um efeito adverso àquele originalmente pretendido, causando prejuízos aos pacientes e reduzindo o passo do progresso biotecnológico ${ }^{23}$.

Contudo, percebe-se ser impossível desenvolver biotecnologia sem uma integração entre diversos campos da ciência, até porque ainda se trata de um setor de fronteira, muito dependente de pesquisa.

A exclusividade de exploração gerada pela patente pode, sob este aspecto, dificultar o desenvolvimento médico e cientifico. Os detentores de patentes de genes podem proibir qualquer profissional de realizar pesquisas para o desenvolvimento/aperfeiçoamento de produtos, métodos e equipamentos ${ }^{24}$.

A este ponto, importante se faz analisar os requisitos necessários para aferição da possibilidade de se patentear genes não naturalmente ocorrentes, quais sejam, a novidade, a atividade inventiva e a aplicação industrial. Como se pode depreender do quanto acima apresentado, deve ser questionada a presença do atributo "atividade inventiva" à concessão de patentes de genes humanos isolados ou sintetizados em laboratório. À parte disso, as diversas aplicações que podem se originar dos genes (inclusive de um mesmo gene), devem também ser pesadas para que se atribua uma extensão adequada à proteção intelectual que venha a ser reivindicada.

Por um lado, as pesquisas genéticas relativas ao sequenciamento e identificação de genes per se envolvem, a priori, mera catalogação de materiais genéticos/componentes bioquímicos já previamente existentes na natureza, não podendo ser consideradas como

\footnotetext{
${ }^{23}$ Para os casos de doenças raras, poderá haver ainda um problema maior, pois falta incentivos a investimentos para estes tipos de pesquisas.

${ }^{24}$ A título ilustrativo, a utilização de genes para identificar mutações capazes no gene associado ao mal de Alzheimer atualmente pode ser explorado apenas pela empresa americana Athena Neurosciences, Inc.
} 
invenções do intelecto humano. Em outras palavras, inexistiria atividade inventiva que esteja intrinsecamente relacionada ao isolamento de tais genes.

De outro lado, o isolamento (ou produção sintética) de genes do DNA humano envolve intervenção humana importante, uma vez que tais genes não naturalmente ocorrentes possuem características materiais diferenciadas em relação àqueles encontrados na natureza e que os permitem servir a certas funções que não podem ser realizadas pelos genes encontrados no DNA em sua forma natural.

Importante também analisar se a identificação da função biológica específica das sequências de referidos genes isolados deve ser considerada condição para se viabilizar a concessão de patentes relativas a tais genes.

Estes são aspectos considerados mais relevantes para que sejam fornecidos subsídios necessários ao aprofundamento da questão da proteção dos produtos e processos biotecnológicos, objeto dos Capítulos 3 e 4 . 


\section{O SISTEMA PATENTÁRIO COMO FORMA DE PROTEÇÃO DE INVENÇÕES BIOTECNOLÓGICAS}

\subsection{A proteção da propriedade intelectual aplicada ao âmbito biotecnológico}

Como será demonstrado neste Capítulo 3.1, importante se faz a implementação de ferramentas jurídicas capazes de fomentar a continuidade do desenvolvimento biotecnológico, tendo em vista os seus importantes resultados - entendidos como produtos da intervenção criativa do intelecto humano -, por meio da concessão de direitos precários que excluam terceiros de sua exploração econômica.

Dentro do âmbito de proteção de direitos intelectuais (aqui entendida em sentido lato), deve-se em primeiro lugar identificar os meios jurídicos pelos quais é possível se assegurar o melhor resultado na composição de interesses de todos os agentes envolvidos na realização de pesquisa e desenvolvimento $(\mathrm{P} \& \mathrm{D})$, sejam eles privados ou públicos, compatibilizando-se ao mesmo tempo o interesse social com o fomento e regulação da atividade empresarial atinente ao tema.

É extremamente difícil a definição da natureza da propriedade que poderia ser conferida a objetos intelectuais, não corpóreos, por se tratarem de bens não rivais e nãoexcluíveis $^{25}$, na medida em que podem estar presentes em qualquer lugar de forma simultânea e não serem consumidos pelo seu uso. Eles não são facilmente apropriáveis, inexistindo um modo não artificial de assegurar os direitos de propriedade intelectual.

Essa característica leva a um primeiro questionamento a respeito do cabimento de se aplicar direitos de propriedade sobre eles: qual seria o motivo pelo qual alguém poderia ter o direito exclusivo de deter e utilizar algo a que toda a coletividade poderia ter acesso e utilizar de forma concomitante?

\footnotetext{
25 “(...) 'nonrivalrous' means that many people can enjoy a good at the same time without depleting it; ideas are nonrivalrous but your personal computer is not. 'Nonexcludable' means that, once you have disclosed the good to others, you cannot easily prevent their using it; again, ideas tend to be nonexcludable whereas tangible things are not." (COTTER, Thomas F. Book Review: Law, Economics, and Intellectual Property. Harvard University Press, Mar. 2004, p. 1).
} 
Ora, o uso de um objeto intelectual por terceiros não priva o seu uso - simultâneo ou não - pelo seu titular ${ }^{26}$. Por esse motivo, de um lado, os direitos de propriedade intelectual possuem um caráter restritivo e, portanto, à primeira vista, não seriam considerados desejáveis sob a ótica da coletividade. As restrições ao livre fluxo de informações e ideias não apenas limitam o desenvolvimento individual do ser humano, mas também impedem o desenvolvimento tecnológico e do conhecimento humano como um todo, que poderiam a partir dele se expandir ${ }^{27}$. Neste contexto, é compreensível que a existência de tais direitos de propriedade intelectual sejam mais difíceis de serem socialmente justificados e aceitos.

Por outro lado, a inexistência de políticas que incentivem a adequada disseminação dessas informações implica a criação de um ambiente cujo resultado é diametralmente o oposto daquele imaginado em uma situação de livre acesso à informação, porquanto ela poderá ser mantida oculta, em segredo, apenas em benefício daquele que a detém (em razão da impossibilidade de terceiros, que não se oneraram de forma alguma para obter tal inovação, beneficiarem-se dela) ${ }^{28}$. Em outras palavras, é preciso que se criem condições favoráveis para que, imediatamente, seja possível o fomento do desenvolvimento da atividade técnica/científica, e, mediatamente, que os resultados daí obtidos sejam compartilhados com o público em geral.

A este respeito, SAMUELSON reconhece que seria justamente este o desafio jurídico a ser enfrentado a fim de que os mecanismos de proteção intelectual evoluam e se adaptem aos novos desenvolvimentos tecnológicos:

\footnotetext{
26 "When two students share a cheese sandwich, each one gets a fraction of it. With most consumer goods like sandwiches, one person's use diminishes what is left for others to use. In contrast, when two students share a digital recording of music, each one gets the whole thing." (COOTER, Robert D; SCHAEFER, Hans-Bernd. Solomon's knot: how law can end the poverty of nations. Princeton: Princeton University Press, 2012, p. 93).

27 "Pode-se acrescentar à função da patente, a proteção do interesse público, ao possibilitar a rápida comercialização dos inventos, além de incrementar a troca de informações, o que evita o dispêndio de esforços com a duplicação de investigação sobre a mesma matéria" (BOFF, Salete Oro. Patentes na biotecnologia e desenvolvimento" in BARRAL, Welber; PIMENTEL, Luiz Otávio (org.). Teoria Jurídica e Desenvolvimento. Florianópolis: Fundação Boiteux, 2006, p. 257).

${ }_{28}$ "The patent system brings inventors' obscure technological feats to the public eye. Without an intellectual property ("IP") regime, innovators would keep their discoveries safely secured from competitors, consumers, and the general public. Society would be starved of knowledge, science would limp forward, and useful information would be stored in a clandestine fashion." (DEVLIN, Alan. The Misunderstood Function of Disclosure in Patent Law. Harvard Journal of Law \& Technology, vol. 23, nº 2, Primavera/2010, p. 401).
} 
"The greatest challenge for intellectual property theorists in the future will be in understanding how the coherence of the existing intellectual property schemes can be maintained or a new coherence created, while at the same time finding ways for these schemes to adapt do new developments." ${ }^{29}$

A divulgação de informações é necessária para que o conhecimento humano se desenvolva; as patentes e os direitos autorais, ao determinar a divulgação de resultados do intelecto humano, têm o potencial de desenvolver o conhecimento humano - e não de restringi-lo. Sob este prisma, depreende-se que a proteção dos bens imateriais pode figurar como um interessante mecanismo de fomentar o intercâmbio e livre fluxo de informações, de forma a se buscar o desenvolvimento do conhecimento humano.

No âmbito da iniciativa privada, a dificuldade estaria, em verdade, no estabelecimento de uma forma adequada de compensação que seja proporcional ao valor agregado por determinada intervenção humana, sendo este um aspecto de grande importância na delimitação da extensão de eventuais proteções intelectuais; e com os desenvolvimentos biotecnológicos, em especial na tutela dos genes humanos ora discutida, essa questão assume especial relevância ${ }^{30}$.

Há, contudo, a possibilidade de se alcançar este mesmo resultado também por meio de políticas públicas de fomento a atividades científicas na universidade. O financiamento estatal, assim, poderia também ser considerado um meio capaz de viabilizar o alcance ao desenvolvimento técnico, que seria revertido em benefício de toda a coletividade de forma livre e irrestrita. Isso porque, neste caso, os incentivos econômicos ligados à proteção de direitos intelectuais não seriam aplicáveis - ao contrário do que ocorre no setor privado, conforme entendimento de SAMUELSON:

\footnotetext{
"One of the questions that inevitably arises when both the private and public sectors perform such research is whether academic researchers should be permitted to patent the results of their research. On the other hand, one could argue that the system assumes that only private profit-making firms need the incentives of exclusivity; academic researchers do not, for a variety of reasons,
}

\footnotetext{
${ }^{29}$ SAMUELSON, Pamela. Innovation and Competition: Conflicts over Intellectual Property Rights in New Technologies. Science, Technology, \& Human Values, vol. 12, nº 1, Inverno, 1987, p. 6.

${ }^{30}$ Tal fato se justifica pela natureza "híbrida" do gene, que pode ser entendido como uma matéria (composto químico) ou como informação, sendo que em sua segunda acepção ele deverá ser como ferramenta de base para o desenvolvimento biotecnológico - como será detalhadamente estudado no Capítulo 4.
} 
require such incentives. (...) Many academics object that patenting of university research results conflicts with the values of academe. Moreover, they argue, such patenting has the potential to 'distort' the research process, that is, to cause researchers to engage in research not because of its intrinsic importance, but because of its potential to supplement their incomes." ${ }^{31}$

No que se refere à realidade brasileira, em que pese existirem programas de incentivo à tecnologia (conforme será visto no Capítulo 5.1.5), inclusive em âmbito biotecnológico, forçoso reconhecer que esta via não pode atualmente ser considerada uma forma consistente e próxima da realidade.

Embora não se negue o importante reconhecimento atribuído por meio de retribuições que confiram distinções honoríficas ou outras formas de recompensas similares, elas não se mostrariam tão efetivas, por lhes faltarem estímulos maiores, dentre os quais destaca-se à atividade humana o interesse material: ninguém abandonaria outros campos de atividade e de trabalho para dedicar-se, sem fito de lucro, a estudos, pesquisas e experiências que muitas vezes absorvem toda uma existência, por simples prazer, por amor ao trabalho desinteressado, por ambição ao renome ou por mero altruísmo ${ }^{32}$.

Assim, um primeiro aspecto a ser considerado diz respeito à recompensa do trabalho humano, por meio da qual se entende que o mais justo e simples seria compensar o inventor com a possibilidade de explorar exclusivamente a invenção e colher os proveitos materiais decorrentes dela (ou seja, recompensá-lo com o fruto do seu próprio trabalho, sobre o qual ele tem direito natural $)^{33}$. Ademais, a competição desleal que poderia ser originada de um ambiente isento de regras que protejam os bens intelectuais poderia reduzir significativamente os incentivos ao investimento em técnicas inovadoras e desenvolvimento de novos produtos, uma vez que as empresas seriam levadas a ter um comportamento parasitário, baseado na cópia e desenvolvimento de produtos e processos similares àqueles originados às custas de seus concorrentes, o que - como já mencionado incentivaria os segredos de negócio.

\footnotetext{
${ }^{31}$ SAMUELSON, op. cit., p. 13-14.

${ }^{32}$ Cerqueira, João da Gama. Tratado da propriedade industrial, vol. I. $2^{\mathrm{a}}$ ed. rev. e atualizada por Luiz Gonzaga do Rio Verde e João Casimiro da Costa Neto. São Paulo: Ed. Revista dos Tribunais, 1982, p. 194.

33 "What a person produces with her own intelligence, effort, and perseverance ought to belong to her and to no one else. 'Why is it mine? Well, it's mine because I made it, that's why. It wouldn't existed but for me"” (HETTINGER, Edwin C. Justifying Intellectual Property. Philosophy and Public Affairs, vol. 18, No.1 (winter, 1989), pp. 31-52, p. 36).
} 
Por esse motivo, CERQUEIRA entende que eventuais objeções contra a proteção do direito do inventor são muito mais de ordem sociológica e econômica do que jurídica, pois a filosofia jurídica garante legitimidade "indiscutível" aos inventores diante da necessidade de reconhecimento e proteção "do direito do homem aos frutos de seu trabalho e de sua atividade intelectual ${ }^{\prime 34}$. O autor confere status de direito natural à propriedade intelectual, sem o qual haveria aniquilação do espírito inventivo "essencial ao progresso social e pródigo de beneficios materiais e culturais" ${ }^{\prime 3}$.

Para além da justificativa da justa compensação pelo trabalho intelectual executado, o argumento da utilidade baseada na concessão de incentivos parece ser a justificativa mais plausível para a propriedade intelectual. É com base nessa premissa que diversas jurisdições, inclusive a brasileira, fundamentam a existência da propriedade intelectual, trazendo à tona os benefícios sociais originados da promoção do progresso técnicocientífico.

De acordo com este argumento, promover a criação de valor a trabalhos intelectuais demanda a concessão de direitos de propriedade sobre tais trabalhos para aqueles que o conceberem, sob pena de se gerar desincentivos aos agentes econômicos em aportar tempo e dinheiro no desenvolvimento de novas tecnologias, pois estariam sempre mais propensos a copiar resultados obtidos por seus competidores.

Ao contrário do que se sustenta pelo argumento anterior, esta justificativa à existência da propriedade intelectual foca nos usuários e beneficiários dessas novas tecnologias, e não nos seus desenvolvedores. Ora, a concessão de direitos de propriedade intelectual aos seus desenvolvedores os estimula a desenvolver novas tecnologias, o que terá por consequência direta a possibilidade de seus usuários delas se beneficiarem futuramente ${ }^{36}$.

Nada obstante, ainda sob este aspecto deve-se considerar que a "garantia dos direitos de propriedade intelectual dá segurança aos inventores e aos investidores, gera

\footnotetext{
${ }^{34}$ CERQUEIRA, op. cit., p. 189.

${ }^{35}$ CERQUEIRA, op. cit., p. 193.

${ }^{36}$ HETTINGER, op. cit., p. 47-49.
} 
riquezas e garante empregos, favorecendo a criação de novos bens e serviços, que contribuem para melhorar as condições de vida dos povos" ${ }^{, 37}$.

Se a justificativa utilitarista é válida para sustentar a concessão de incentivos para o fomento ao desenvolvimento tecnológico como um meio para se atingir uma finalidade social, então esta busca de incentivos capazes de promover o desenvolvimento de novos produtos intelectuais deve ser estimulada. Por outro lado, deve-se igualmente se atentar pela necessidade de um equilíbrio na extensão de tal proteção a fim de se evitar a excessiva restrição de sua disponibilidade e uso.

Isso porque a ideia do conhecimento à disposição de todos é, sem dúvida alguma, a ideal, mas não condiz muito com a realidade atual. Hoje, é sabido que são diversas as barreiras entre as pessoas e o conhecimento, sejam elas de ordem social, econômica, cultural, institucional, moral etc. Deste modo, uma ferramenta estatal desta natureza deve se mostrar balanceada, pois uma proteção que seja muito ampla poderá gerar distorções de mercado e impossibilitar o desenvolvimento científico e tecnológico.

O que se deve levar em consideração, portanto, é que não apenas a remuneração do esforço intelectual deve ser premiada como forma de se justificar a existência e validade da propriedade intelectual; deve-se também considerar o caráter da utilidade social que tais produtos devem possuir. Deste modo, mostra-se imperioso determinar quais são as regras legais que podem figurar como instrumento mais adequado para se garantir a disseminação e o acesso ao conhecimento daí gerado.

Como será visto, os direitos sobre os bens intelectuais não envolvem a concessão do direito de se deter exclusivamente tais formas de conhecimento: eles dizem respeito à exclusão do direito de utilização de referidos "bens intelectuais" para certas finalidades. Tais direitos são estabelecidos de forma temporária, a fim de permitir ao seu detentor o direito de auferir resultados econômicos de sua exploração, inclusive para obter retorno do investimento inicial, em detrimento de terceiros que não se oneraram de forma alguma para obtê-lo.

\footnotetext{
${ }^{37}$ BOFF, Salete Oro. Patentes na biotecnologia e desenvolvimento. In: Barral, Welber; Pimentel, Luiz Otávio (org.). Teoria Jurídica e Desenvolvimento. Florianópolis: Fundação Boiteux, 2006, p. 279.
} 
A extensão dessas limitações de uso impostas pelos sistemas de proteção de direitos intelectuais é que deve ser analisada, a fim de se identificar uma equação equilibrada que aponte justamente para o desenvolvimento do conhecimento humano. A proibição de concessão de proteções amplas, que não serão justificáveis por serem inúteis e serem um desperdício, em razão da característica de não-exclusividade dos bens intelectuais, deve ser também uma condição a ser considerada.

A existência de um mecanismo por meio do qual o Estado assegure uma determinada contraprestação atrelada à necessidade de revelar todo o segredo contido na criação técnica inovadora, bem como o direito de excluir terceiros de sua exploração econômica, pode se mostrar uma forma efetiva de possibilitar uma organização de agentes diversos na consecução de tal desiderato. Neste ponto, se mostra relevante o reconhecimento da economia do conhecimento como elemento de mundial interesse e importância, bem como a propriedade intelectual como forma de se regulamentá-la. A este respeito, STIGLITZ afirma o seguinte:

"Intellectual property has become one of the major issues of our global society. Globalization is one of the most important issues of the day, and intellectual property is one of the most important aspects of globalization, especially as the world moves toward a knowledge economy. How we regulate and manage the production of knowledge and the right of access to knowledge is at the center of how well this new economy, the knowledge economy, works and of who benefits. At stake are matters of both distribution and efficiency." 38

Sob este aspecto, deve-se considerar o cabimento e interesses (tanto públicos quanto privados) relacionados à existência de um ambiente desprovido de qualquer tutela ou regulamentação a respeito, em contraposição à existência de possíveis mecanismos capazes de proporcionar sua contínua evolução ${ }^{39}$. Como bem esclarece IACOMINI, evidenciando o interesse social de acesso a tais tecnologias:

"A biotecnologia invadiu os organismos viventes (animais, plantas $e$ microorganismos e outros materiais biológicos) e seus subgrupos celulares,

\footnotetext{
${ }^{38}$ STIGLITZ, Joseph E. Economic Foundations of Intellectual Property Rights. Duke Law Journal, vol 57, 2008, p. 1695.

${ }^{39}$ Sem se descuidar, obviamente, dos efeitos que tais direitos de propriedade poderão causar aos inventores subsequentes, sendo este assunto objeto de discussão no Capítulo 4.
} 
para trabalhar a matéria viva e obter dela um resultado útil, para fabricação ou modificação de produtos que implicam em melhorias na qualidade de vida do ser humano, otimizando de uma maneira racional a forma como interagem com a natureza de modo a suprirem as necessidades de sobrevivência." ${ }^{40}$

No caso do desenvolvimento de pesquisas científicas de ponta, como aquelas na área da engenharia genética, tal situação se mostra ainda mais sensível, pois elas demandam vultosos investimentos classificáveis como sendo de alto risco, na medida em que seus resultados práticos baseiam-se na ciência experimental e dependem de uma série de outros fatores ${ }^{41}$, de modo que sua possível exploração comercial é incerta, e - mesmo nesta situação - os retornos estimados são de longo prazo.

O mais importante neste contexto seria assegurar a manutenção dos investimentos em pesquisa e a consequente manutenção do fluxo de produção de novas tecnologias, especialmente quando se busca incentivar o desenvolvimento econômico no Brasil. Nas palavras de WOLFF e ANTUNES:

"Do ponto de vista prático, a patente de um medicamento tem a duração de cerca de 6 (seis) anos entre a data de sua concessão e o término de sua validade, periodo no qual os investimentos devem ser recuperados, sob pena de o produto ser um fracasso comercial, ainda que possa ser excelente, nos aspectos medicinais. Esse curto espaço de tempo é designado como vida efetiva da patente. A manutenção dos mecanismos de proteção da propriedade intelectual, por intermédio das patentes, é extremamente importante para que os investimentos continuem a ser gerados e novo medicamento produzido. Qualquer pressão para que os mecanismos de proteção da propriedade intelectual referente aos medicamentos sejam enfraquecidos criará seguramente uma redução de investimentos privados em novos produtos. ${ }^{24}$

Indubitavelmente, as evoluções observadas nas técnicas biotecnológicas acabaram por atrair maiores e pujantes investimentos para o setor. Destarte, emerge a necessidade de

\footnotetext{
${ }^{40}$ IACOMINI, Vanessa. Biotenologia: repercussões jurídicas e sociais da pesquisa sobre genoma humano. In: BARRAL, Welber; PIMENTEL, Luiz Otávio (org.). Teoria Jurídica e Desenvolvimento. Florianópolis: Fundação Boiteux, 2006, p. 285.

${ }^{41}$ Isso se deve ao fato de que podem não resultar efetivamente em produtos seguros ou que apresentem a eficiência deles esperada; ou, ainda que se atinjam os resultados esperados, podem existir riscos de rejeição pelo mercado consumidor e também quanto à difusão dos produtos no mercado.

${ }^{42}$ WOLFF, Maria Thereza; ANTUNES, Paulo de Bessa. Patentes de Segundo Uso Médico. Boletim Científico ESMPU, Brasília, a. III - n. 13, p. 115-131 - out./dez. 2004, p. 117.
} 
instrumentos jurídicos e administrativos que garantam maior viabilidade aos vultosos investimentos realizados. Caso não exista um sistema de proteção jurídica adequado que outorgue direitos aos resultados dos trabalhos/investimentos biotecnológicos, os riscos poderiam não ser assumidos pelos inventores e empresas que financiam tais trabalhos.

Vê-se, assim, que há um esforço dispendido atrelado ao desenvolvimento biotecnológico de grande relevância, que consiste tanto na dificuldade experimentada na obtenção do resultado tecnológico buscado, quanto no risco voluntariamente assumido na busca por tal resultado, e, ainda, no seu nível de importância social.

Considerados todos esses aspectos, deve-se buscar um ambiente propício à busca do justo e necessário balizamento dos interesses no investimento de recursos (técnicos, financeiros, etc.) para a criação de um determinado bem intelectual, em contraposição ao interesse social em ter acesso a ela. Assim, a divulgação de determinado bem intelectual para a concessão de tais direitos de exploração exclusiva figura como condição fundamental; porém, deve tal bem ser qualificado de forma a justificar seu interesse público, razão pela qual tal bem deve possuir características especiais determinadas que lhe permitam distingui-lo de intervenções humanas ordinárias.

Ultrapassada a questão da pertinência da proteção dos direitos intelectuais pelo Estado (obviamente observados determinados limites e critérios) - inclusive e especialmente no âmbito dos desenvolvimentos biotecnológicos - importa avaliar quais seriam os mecanismos mais adequados, para que em seguida seja verificado se os sistemas atualmente vigentes são cabíveis no âmbito das proteções biotecnológicas e quais seriam as possíveis adequações para que se atinja uma composição de interesses públicos e privados consistente, capaz de atender ao desenvolvimento tecnológico buscado.

Em primeiro lugar, serão avaliados os segredos de negócio. Como será visto, eles envolvem uma série de informações de natureza confidencial que não são a priori de conhecimento público, e cuja proteção confere ao seu detentor uma vantagem competitiva. Os segredos de negócio podem ou não estar sujeitos à proteção intelectual (seja em âmbito dos direitos autorais quanto aos direitos de patentes) ${ }^{43}$.

\footnotetext{
${ }^{43}$ Neste contexto, deve-se distinguir os termos "tecnologia" e "inovação". Pode haver tecnologia sem que necessariamente haja inovação tecnológica. Nos termos da Lei $n^{\circ} 11.196 / 05$, somente haverá inovação
} 
Por sua natureza, é possível desde já verificar que um sistema de proteção de bens intelectuais que encoraje a manutenção de segredos de negócio terá como resultado uma limitação ao acesso à informação não desejável ao contínuo desenvolvimento tecnológico na área da genética médica, ao passo que as patentes e os direitos de autor, não.

Em seguida, será discutido o cabimento da proteção conferida pelas leis de direito autoral às criações de natureza técnica e científica, e como tais mecanismos poderiam eventualmente se relacionar com a geração dos necessários incentivos à continuidade do desenvolvimento biotecnológico buscado.

Ao final, considerando-se a natureza e finalidade dos desenvolvimentos tecnológicos na área da engenharia genética, verificar-se-á que o meio mais adequado para assegurar sua propriedade é a concessão de privilégio temporário pela via patentária. Uma prova da universalidade de aceitação desse modelo de recompensa é a aplicação do mesmo por "todos os países" 44 , que utilizam solução similar.

\subsubsection{Os desenvolvimentos biotecnológicos como segredos de negócio}

Os segredos de negócio podem ser caracterizados como sendo determinada informação ou conjunto de informação e processos não disponível a outros agentes atuantes em um mesmo mercado relevante e mantido sigiloso como forma de se conferir ao seu detentor uma vantagem competitiva em relação aos seus concorrentes. A este respeito, FRIEDMAN destaca que:

\footnotetext{
"A trade secret is an item of information - commonly a customer list, a business plan, or manufacturing process - that has commercial value and that the firm possessing the information wants to conceal from its competitors in order to prevent them from duplicating it. It is questionably described as 'property' in a recent Supreme Court decision that upheld a conviction for fraud under a statue
}

\footnotetext{
tecnológica, se houver: (a) a concepção de um novo produto/processo de fabricação; e (b) agregação de novas funcionalidades ou novas características a produto/processo de fabricação que impliquem melhorias e efetivo ganhos de qualidade ou produtividade. A inovação é também neste mesmo sentido definida na Lei 10.973/2004 (Lei do Bem), em seu artigo $2^{\circ}$, inciso IV, segundo a qual é caracterizada por uma "introdução de novidade ou aperfeiçoamento no ambiente produtivo ou social que resulte em novos produtos, processos ou serviços".

${ }^{44}$ CERQUEIRA, op. cit, p. 192.
} 
(the federal mail-fraud statute) that has been interpreted to require that the fraud deprive the victim of something tangible - something like property but unlike the right to honest service. A trade secret is not property in the usual sense - the sense it bears in the law of real and personal property or even in such areas of intellectual property law as copyright-because it is not something that the possessor has the exclusive right to use or enjoy" ${ }^{45}$.

Por esse motivo, a informação protegida pelo segredo de negócio deve não ser de conhecimento público ou de fácil acesso e possuir um valor econômico que se traduz em vantagem competitiva a seu detentor ${ }^{46}$.

Historicamente, os segredos de negócio se mostravam como a forma mais comum de proteção intelectual. A utilização dos segredos de negócio se mostrava mais adequada em relações profissionais baseadas na confiança entre seus agentes, figurando de forma deveras comum em épocas que precederam a era industrial (quando os segredos de negócio relativos a determinadas manufaturas eram ensinados a poucos aprendizes, que levariam adiante o negócio).

Com a Revolução Industrial, passou a se mostrar cada vez mais importante a existência de mecanismos capazes de proteger tais segredos de negócio em razão de um mais amplo número dos profissionais envolvidos no processo produtivo de determinada mercadoria, o que deixaria referidas vantagens competitivas mantidas sigilosas muito mais expostas à utilização indevida/desonesta por terceiros.

Não se deve confundir tecnologia não patenteada com segredos de indústria ou negócio. A tecnologia não patenteada (ou know-how) é o gênero do qual segredos empresariais é espécie, abrangendo tecnologia patenteável ou não, que se qualifique ou não como segredo empresarial. A esse respeito:

“(N)ão há que se confundir tecnologia (know-how) pura e simples com tecnologia secreta (secret know-how ou trade secret). Na primeira hipótese,

\footnotetext{
${ }^{45}$ FRIEDMAN, David D.; LANDES, William M.; POSNER, Richard A. Some Economics of Trade Secret Law. Journal of Economic Perspectives, vol. 5, no. 1, Inverno/1991, p. 61-62.

46 "The information must not be generally known or readily accessible, must have value because it is secret, and must be the subject of "reasonable steps" to keep it secret. This general formula for trade secret laws has been adopted by well over 100 of the 159 members of the World Trade Organization" (POOLEY, James. Trade Secrets - the other IP right. WIPO Magazine, vol. 3, 2013).
} 
trata-se de conhecimento que pode ser dominado por mais de uma empresa do ramo, mas de acesso restrito às demais, ao passo que, na segunda hipótese, se fala de conhecimento ao qual ninguém, além do titular, tem acesso, salvo com seu consentimento expresso."47

O detentor da tecnologia que se qualifique como segredo empresarial, pode: (a) impedir divulgação/exploração econômica por terceiros (a menos estes que cheguem à mesma solução técnica por vias autônomas e legítimas); (b) pleitear indenização civil por violação a direitos; (c) no caso de crime de concorrência desleal, propor queixa-crime contra os infratores; e (d) nas hipóteses dos artigos 153 e 154 do Código Penal, apresentar representação contra os infratores.

Identifica-se, a partir daí, que uma característica marcante dos segredos industriais reside na inexistência de proteção contra terceiros que desenvolvam/obtenham a mesma tecnologia de forma autônoma e legítima; a proteção conferida ao detentor do segredo industrial se resume à imposição de sanções àquele que o viola diretamente, em razão de tal prática configurar ato de concorrência desleal. Trata-se, portanto, de uma forma de proteção mais frágil em comparação com aquela concedida pelos direitos autorais e patentários, senão vejamos:

"If through accident the secret leaks out, or if a competitor unmasks it by reverse engineering, the law gives no remedy. The law does give a remedy if the secret is lost through a breach of contract - say by a former employee who had promised not to disclose what he learned on the job - or through a tort, like trespass. But the violation is not of a property right to the secret but of a common law right defined regard to trade secrets or to information in general." 48

"Trade secret law thus provides strong protection against wrongful actors, but it offers no defense against someone that discovers the secret by 'fair and honest means', such as independent invention or reverse engineering. In this way, the monopoly offered by trade secret is much more fragile than a patent. It may lawfully be defeated through independent invention, reverse engineering or other legitimate means. And, once the secret is disclosed, it is lost forever. On the

\footnotetext{
${ }^{47}$ CORREA, José Antonio Faria, in SANTOS, Manoel J. Pereira dos; JABUR, Wilson Pinheiro. Contratos de Propriedade Industrial e Novas Tecnologias - Propriedade Intelectual. São Paulo: Saraiva, 2007, Série: GVlaw, p.149.

${ }^{48}$ FRIEDMAN, David D.; LANDES, William M.; POSNER, Richard A., op. cit., p. 61-62.
} 
other hand, if the secret is kept, trade secret law offers protection in perpetuity." 49

Por outro lado, por serem indefinidos, os benefícios são desproporcionais ao esforço dispendido para seu desenvolvimento. Para a sociedade em geral, há o risco de monopólio eterno (apesar de mais frágil), pois não existe no trade secret o ônus de divulgar ao público o conteúdo protegido, como ocorre com as patentes ${ }^{50}$.

Por isso, negar-se qualquer tipo de tutela jurídica que incentive a proteção dos genes pode ser medida extrema, pois neste caso as pesquisas biotecnológicas estarão sujeitas a proteções garantidas apenas pelos segredos industriais, o que certamente irá desacelerar o passo do desenvolvimento no campo da genética médica, porquanto tem como princípio básico a não divulgação de informações ${ }^{51}$. Tal hipótese certamente irá limitar o acesso e disseminação dos conhecimentos relevantes para a evolução contínua da biotecnologia ${ }^{52}$, especialmente em razão de outros aspectos de grande relevância que são marcantes no campo da pesquisa e desenvolvimento biotecnológico: as elevadas barreiras à entrada de agentes capazes de realizar pesquisas de ponta, em razão dos custos envolvidos e riscos inerentes ao tempo de retorno do investimento, que muitas vezes sequer se materializa.

\subsubsection{O amparo da lei de direitos autorais à pesquisa e desenvolvimento em biotecnologia}

Os direitos autorais prestam-se a proteger toda obra ou criação subjetivamente original de natureza literária, artística ou científica, que tenha sido expressa por qualquer meio ou suporte. Neste sentido, importa analisar se os produtos e processos originados das

\footnotetext{
${ }^{49}$ SCHWARTZ, Andrew A. The Corporate Preference for Trade Secret. Northwestern Law, Abril/2013, p. 8. 50 "This does not mean, of course, that any given trade secret will persist forever. To the contrary, trade secret protection can cease to exist at any time. But the important point is that trade secrets have the capacity to endure perpetually - a capacity that patents lack" (SCHWARTZ, op. cit., p. 10).

${ }^{51}$ Neste sentido, ensina Cerqueira que não proteger os direitos do inventor seria induzi-lo a agir de modo antissocial, "explorando egoisticamente os seus inventos, pois a abolição dos privilégios incrementaria os segredos de fábrica" (CERQUEIRA, op. cit., p. 193).

52 "In sharp contrast to patent law, however, trade secret does not require any disclosure to the public. As such, trade secret law does not encourage the public dissemination of knowledge in the way that patent law does" (SCHWARTZ, op. cit., p. 11).
} 
inovações na área da biotecnologia podem ser considerados obras passíveis de proteção autoral, bem como se tal forma de proteção é suficiente.

Grande parte da doutrina já aferiu pela impossibilidade prática de se conferir proteção autoral às inovações surgidas na área da biotecnologia, em razão de não ser possível um adequado enquadramento de tais objetos às tradicionais figuras do direito autoral. Isso se deve, em primeiro lugar, pela aparente impossibilidade de se considerarem originais e independentes os desenvolvimentos biotecnológicos, em especial no que se refere à tutela jurídica dos genes, porquanto se trata de matéria preexistente na natureza. Nesse diapasão, DOMINGUÉZ coloca em pauta o seguinte questionamento:

\footnotetext{
“Otra cuestión que se plantea la doctrina es sobre el requisito de originalidad indispensable para el nacimiento (y consideración como tal) de una obra, susceptible de protección por los derechos de autor. Es decir, ¿se puede entender original e independiente, el resultado de la innovación biotecnológica, sobre materia viva, preexistente en la naturaleza, conforme con los requisitos necesarios para la consideración de la obra? (...) Resumiremos que resulta muy difícil, por no decir, inviable, la utilización de los derechos de autor como instrumento eficaz de protección de las invenciones biotecnológicas." 53
}

Muito embora a expressão de uma ideia ou de um determinado objeto pré-existente na natureza possa ser dotado de originalidade subjetiva capaz de lhe garantir proteção autoral, fato é que a proteção buscada para fins de se garantir a continuidade do desenvolvimento biotecnológico se refere aos objetos biotecnológicos per se.

Os direitos autorais estão mais relacionados, portanto, à forma de se expressar uma determinada criação e não ao conteúdo propriamente dito. Este seria o principal traço distintivo dos direitos de autor em relação às patentes, que parece ser suficiente para se descartar o copyright como forma de proteção mais adequada aos desenvolvimentos biotecnológicas, tendo em vista a lição de BARBOSA:

“A doutrina que prevalece desde os primeiros dias da propriedade intelectual destina as leis de patentes a proteger o conteúdo utilitário das invenções

\footnotetext{
${ }^{53}$ DOMÍNGUEZ, Jorge García. Un acercamiento a la patentabilidad de las invenciones tecnológicas. Revista Facultad de Derecho y Ciencias Políticas (Universidad Pontificia Bolivariana), vol. 36, $\mathrm{n}^{\circ}$ 104, Jan/Jun, 2006, p. 118-119).
} 
tecnológicas. O copyright ou droit d'auteur iria voltar-se à forma expressiva e não ao conteúdo das respectivas criações - muito menos, ao conteúdo utilitário.

Desta maneira, a utilização industrial de qualquer tecnologia funcionalmente equivalente àquela que foi patenteada é restrita segundo a lei pertinente, ainda que os conhecimentos técnicos intrínsecos na patente possam ser livremente utilizados em qualquer propósito intelectual, científico e não-industrial.

O copyright e os direitos de autor não podem ser utilizados para restringir quaisquer obras funcionalmente equivalentes: por definição, as obras literárias, artísticas ou científicas não têm qualquer funcionalidade além de expressar ideias, conceitos e sensações, todas elas com circulação livre de qualquer restrição jurídica." ${ }^{, 54}$

A jurisprudência do Supremo Tribunal Federal (STF) já teve a oportunidade de se manifestar sobre o assunto, e corrobora justamente o entendimento acima apresentado, por reconhecer que o direito autoral se presta a proteger a forma de expressão de um trabalho científico, porém "não as conclusões cientificas ou seus ensinamentos"

Os textos científicos, embora possam ser dotados de originalidade subjetiva, estão mais relacionados à divulgação de descobertas e conhecimentos técnicos obtidos a partir de uma pesquisa experimental que não necessariamente busca uma solução prática a um problema técnico.

Ademais, os resultados práticos obtidos a partir da aplicação prática de um determinado desenvolvimento biotecnológico não são protegidos pela lei de direitos autorais, mas apenas a obra em si - esta entendida como uma expressão subjetiva de natureza técnica e científica, apresentada por qualquer suporte material, resultado do

\footnotetext{
${ }^{54}$ BARBOSA, Denis Borges. Direito de autor: questões fundamentais de direito de autor. Rio de Janeiro: Lumen Juris, 2013, p. 9.

55 "Bula de remédios. Reconhecida a sua natureza científica, pois destinada a classe medica e farmacêutica e fiscalizada pelas autoridades competentes, legitima-se a simples referência ou citação de uma pesquisa cientifica sem ofensa ao direito do Autor, face ao Código Civil e a Lei Especial. Aplicação dos arts. 666, I, do C.Civil e art. 49, I e III, da Lei 5988, de 14.02.75, e não incidência, na espécie, do art. 25, IV. Da mesma Lei. Nos trabalhos científicos o Direito Autoral protege a forma de expressão, e não as conclusões cientificas ou seus ensinamentos, que pertencem a todos, no interesse do bem comum. Ação proibitória cujos resultados já tinham sido alcançados pela notificação previa. RE conhecido e provido para julgar improcedente a ação proibitória." (STF. RE 88705 RJ. Min. Rel. Cordeiro Guerra. Segunda Turma. J. 25/05/1979).
} 
intelecto criativo humano - e sua forma de exploração econômica (os chamados direitos patrimoniais do autor).

Ora, uma publicação científica confere reconhecimento e notoriedade ao seu autor no meio acadêmico - e pode ter, como consequência direta, o encorajamento ao desenvolvimento de novas tecnologias a partir de tal trabalho pelos demais membros de sua comunidade científica -, porém, isso não necessariamente se traduz em benefícios financeiros àquele que engendrou esforços na busca de tal desenvolvimento.

Isso porque, muito embora tenha condições de exploração econômica de tal obra científica, mostra-se grande a dificuldade em proteger seu conteúdo contra a utilização por terceiros: o direito autoral proíbe a cópia de referida obra, porém expressões subjetivas que contenham conteúdo similar poderão ser alcançados ${ }^{56}$.

Desta feita, a lei autoral não impedirá terceiros de buscar uma aplicação prática para tal conhecimento, pois tal forma de proteção se encontra no âmbito de proteção da lei de propriedade industrial, caso se enquadre como patente ou modelo de utilidade. Tal situação, portanto, não apresenta suficiente incentivo para motivar a realização dos elevados e arriscados investimentos em pesquisa e desenvolvimento na área da genética médica, muito embora os direitos autorais possuam prazo de proteção mais alongado em relação às patentes.

Forçoso concluir-se, assim, pela inadequação de referida tutela legal aos desenvolvimentos originados dos avanços biotecnológicos. Afinal, os produtos daí originados devem em si estar diretamente relacionados a um procedimento vinculado a uma aplicação prática e útil, que se reverta em alguma forma de benefício à sociedade, para que se justifique a proteção intelectual nos termos que ora se discute, nos termos do art. $5^{\circ}$, XIX, da Constituição Federal (CF/88).

\footnotetext{
56 "One reason patent protection can be more valuable than copyright protection is that a patent protects against any duplication of the patented invention rather than merely forbidding the copying of it. (...) Simultaneous or nearly simultaneous discovery or invention is much more common in the case of ideas, which are (more precisely, a subset of which are) what patents protect from duplication, than in the case of expression, the domain of copyright law. That is why there are patent races but not copyright races" (LANDES, William M.; POSNER, Richard A. The economic structure of intellectual property law. Cambridge: Harvard University Press, 2003, p. 295).
} 
Exceção a esta regra parece ser apenas nos casos de desenvolvimentos biotecnológicos que estejam de alguma forma atrelados às inovações informáticas e aos programas de computador ${ }^{57}$. Refere-se, aqui, à bioinformática, campo do conhecimento que contempla um conjunto de técnicas multidisciplinares, tais como métodos computacionais, algoritmos matemáticos, estatística, dentre outros, voltados ao gerenciamento e tratamento de informação biotecnológica, notadamente vinculada à biologia molecular, em especial, a genômica.

Por meio da aplicação dos conhecimentos combinados inerentes à bioinformática, é possível o desenvolvimento de softwares que são capazes de identificar genes, prever a configuração tridimensional de proteínas, identificar inibidores de enzimas, organizar e relacionar informação biológica, simular células, montar árvores filogenéticas, comparar sequencias de DNA, dentre outras. Tais ferramentas, concebidas na forma de programas de computador, são passíveis de proteção autoral.

\subsubsection{A proteção patentária aplicada à engenharia genética}

Considerando-se que o sistema patentário possui um viés de oferecer estímulos à inovação com o fim de se promover o progresso científico e o desenvolvimento econômico-social, a sua concessão deve ser avaliada de forma bastante criteriosa, para que não sejam geradas consequências adversas.

A patente somente pode ser justificada como aceitável caso concedida àquele que promover como resultado de sua pesquisa uma melhora da qualidade de vida capaz de solucionar problemas práticos, de forma que não seja pela simples evolução normal da técnica ou decorrente de meras descobertas.

Uma patente, na sua formulação clássica, é um direito, conferido pelo Estado, que dá ao seu titular a exclusividade da exploração de uma tecnologia que atenda a determinadas características. Como contrapartida pelo acesso do público ao conhecimento dos pontos essenciais do invento, a lei dá ao titular da patente um direito limitado no

\footnotetext{
${ }^{57}$ No entanto, há um setor no qual ainda seria cabível a proteção por direitos autorais, "cual es la bioinformática y sistema de software biotecnológico, cuestión esta que podría entenderse como nueva manifestación de la propiedad intelectual" (DOMÍNGUEZ, op. cit., p. 119).
} 
tempo, no pressuposto de que é socialmente mais produtiva em tais condições a troca da exclusividade de fato (a do segredo da tecnologia) pela exclusividade temporária de direito $^{58}$.

Assim sendo, a patente tem seu pressuposto pautado na extinção do antigo segredo industrial, com vistas ao benefício da sociedade ante a divulgação do conhecimento tecnológico, resguardados, porém, e de maneira limitada no tempo, os direitos de seu possuidor originário ${ }^{59}$, sendo esta, portanto, uma importante característica inerente às patentes $^{60}$.

A Lei 9.279/1996 (LPI), dispõe sobre os direitos e as obrigações relativas à propriedade industrial, abrangendo a tutela jurídica da invenção, do modelo de utilidade, do desenho industrial e da marca. Especificamente no que interessa ao escopo do presente trabalho, para a invenção e o modelo de utilidade, a proteção outorgada pelo Estado se dá através da concessão de patentes.

A análise de pertinência de referida forma de proteção legal importa em conceber a invenção como uma criação nova, dotada de aplicação industrial e/ou econômica e, principalmente, tendo como origem atividade criativa e inventiva de natureza técnica do espírito humano, voltadas à solução de uma dificuldade técnica. O sistema de patentes acabou alçado a importância estratégica, passando a galgar espaço em um momento de fronteira em que se debatem as novas necessidades da indústria biotecnológica e a necessidade de privilegiar efetivas invenções, e não meras descobertas.

\footnotetext{
${ }^{58}$ BARBOSA, Denis Borges. El Comercio de Tecnología: Aspectos Jurídicos, Trasferencia, Licencia y 'Know-how'. Revista de Derecho Industrial, vol. 30, 1988, passim.

59 "One of the central benefits for patent protection is that the public immediately gains access to information that was costly to produce, information that firms would otherwise keep as proprietary trade secret." (JACKSON, Brian A. Innovation and Intellectual Property: The Case of Genomic Patenting. Journal of Policy Analysis and Management, vol. 22, no. 1, Maio/2003, p. 15).

60 "A twist not present in the copyright area (with some exceptions noted later) is that in the absence of legal protection for an invention, the inventor will try to keep the invention secret, thus reducing the stock of knowledge available to society as a whole. Patent law combats this incentive by requiring, as a condition of the grant of a patent, that the patent application (which becomes a public document if and when the patent is issued, and often in any event, as we'll note in Chapter 13, eighteen months after filing) disclose the steps constituting the invention in sufficient detail to enable readers of the application, if knowledgeable about the relevant technology, to manufacture the patented product themselves. Of course they may not use the information to make or sell or use the patented product or process itself without a license from the patentee, but they may use it for any other purpose, including attempting to 'invent around' the patented inventionthat is, to achieve the technological benefits of the patent without duplicating the particular steps constituting it and thus without infringement" (LANDES; POSNER, op. cit., p. 295).
} 
A aquisição da propriedade intelectual não deve trazer prejuízos a terceiros, no sentido de levá-los a uma condição menos favorável do que aquela por eles detida numa situação em que tal proteção não tenha sido concedida. Tal assertiva se mostra, à primeira vista, incompatível com o próprio conceito de patente, em razão da forma da exploração econômica conferida a direitos intelectuais, que pode limitar a livre exploração de um invento obtido de forma independente posteriormente. Entretanto, essa visão deve ser analisada com ressalvas, pois a invenção sequer estaria disponível a terceiros, não fossem os esforços primeiramente dispendidos pelo detentor da nova tecnologia desenvolvida.

A fim de que a patente tenha lugar, parte-se do pressuposto de que as novas tecnologias são sempre em benefício da sociedade, ou seja, deve primeiramente existir um interesse social pela proteção à inovação biotecnológica. A patente somente pode ser justificada como aceitável caso concedida àquele que tiver como resultado de sua pesquisa uma melhora da qualidade de vida, capaz de solucionar problemas práticos de forma que não seja pela simples evolução normal da técnica ou que seja decorrente de meras descobertas.

No caso dos desenvolvimentos biotecnológicos na área da genética médica, tais benefícios estão relacionados aos genes humanos potencialmente exploráveis na busca de novos antibióticos e agentes terapêuticos, probióticos, produtos químicos, enzimas e polímeros para aplicações industriais e tecnológicas. Isso será resultado de estudos técnicos que terão por base a exploração do conteúdo informacional identificado pelo sequenciamento do genoma humano.

O próprio Acordo TRIPS, em seu artigo 27(1), assegura a concessão de direitos sem nenhum tipo de discriminação em relação ao campo tecnológico:

"Sem prejuízo do disposto nos parágrafos 2 e 3 abaixo, qualquer invenção, de produto ou de processo, em todos os setores tecnológicos, será patenteável, desde que seja nova, envolva um passo inventivo e seja passível de aplicação industrial. Sem prejuizo do disposto no parágrafo 4 do Artigo 65, no parágrafo 8 do Artigo 70 e no parágrafo 3 deste Artigo, as patentes serão disponíveis e os direitos patentários serão usufruieis sem discriminação quanto ao local de invenção, quanto a seu setor tecnológico e quanto ao fato de os bens serem importados ou produzidos localmente." (grifo nosso) 
Desta feita, apontando-se pela aplicabilidade de tutela jurídica ao caso em análise (conclusão esta a que se chegará após as análises dos Capítulos que se seguem), resta a proteção patentária como instrumento jurídico apropriado para a proteção das invenções biotecnológicas (no caso, os genes humanos). E, embora não uníssono, não raro é o apoio a tal mecanismo de proteção também pela comunidade científica:

"Many basic scientists and clinicians support the right to obtain and enforce
patents on drugs, diagnostic tests, medical devices and most recently, genes.
Some primarily are concerned with recovering the costs they incur in developing
new treatments and technologies. Others see patents in medicine as a legitimate
means, within a society based on the principle of free enterprise, of protecting
and enhancing intellectual capital."

Entretanto, tendo em vista que invenções mecânicas e biológicas se referem a âmbitos completamente diversos, tal assertiva deve ser vista com reservas. A concessão de patentes a materiais genéticos humanos poderá desvirtuar o sistema de patentes e ser capaz de gerar consequências opostas àquelas almejadas, desestimulando novas pesquisas (aquelas de caráter aplicado que utilizam a engenharia genética como ferramenta para seus produtos finais) e freando o desenvolvimento científico, pois pode criar um ambiente capaz de incentivar a não divulgação de determinadas inovações biotecnológicas.

Neste contexto, importa lembrar que a noção clássica de patentes atribuída às invenções tradicionais, mecânicas, deve em princípio compreender todo e qualquer uso relativo ao objeto protegido, contanto que (a) tenham aplicabilidade industrial; (b) sejam uma novidade no mercado; e (c) decorram de atividade inventiva, ou resultem em melhoria funcional no uso ou fabricação de objeto já existente.

Este entendimento por si só, se aplicado de forma indiscriminada às invenções biotecnológicas, poderá gerar um problema com relação a patentes dependentes que sejam originadas de um mesmo gene patenteado, porquanto poderá - em última análise -

${ }^{61}$ American College of Obstetricians and Gynecologists - ACOG. Patents, Medicine, and the Interests of Patients. ACOG Committee Opinion no 277, vol. 100. 5 Nov. 2002, p. 1051. 
implicar o controle total e irrestrito do seu conteúdo informacional pelo detentor de tal patente $^{62}$.

Deve-se, portanto, atribuir uma correta compreensão ao sistema de patentes e aos interesses que o norteiam, para se entender pelo enquadramento dos resultados do desenvolvimento biotecnológico ao âmbito de proteção patentária, bem como pela extensão da proteção a ser conferida. Uma série de problemas será suscitada e discutida para que se possa avaliar a pertinência e amplitude que se deve conferir a este tipo de proteção.

Estes aspectos mais específicos, atinentes à amplitude e discussão da melhor forma de se adequar a proteção patentária aos produtos e processos biotecnológicos, terá destaque no Capítulo 4.

\subsection{Princípios e objetivos do sistema patentário}

Como visto no Capítulo anterior, patentear tecnologia é um importante mecanismo não apenas para assegurar a recuperação de investimentos feitos em $\mathrm{P} \& \mathrm{D}$, mas também para promover o intercâmbio e acesso a tais informações.

O viés da remuneração ao trabalho intelectual humano possui como resultado prático direto a possibilidade de recuperar os imprescindíveis investimentos em pesquisa e desenvolvimento. A este respeito, BARRAL e PIMENTEL sustentam que:

\footnotetext{
"Os direitos da propriedade intelectual são instrumentos que permitem uma posição jurídica (titularidade) e uma posição econômica (exclusividade). A proteção jurídica tende a garantir, ao seu titular, a recuperação de investimentos na pesquisa e desenvolvimento $(P \& D)$ tecnológico, que podem ser públicos ou privados, diretos ou indiretos. Garante também uma posição econômica privilegiada e lícita nos mercados regionais ou nacional, para uma empresa em concorrência com outra, ao permitir a exclusividade de processo
}

\footnotetext{
62 "Because these patents grant rights to portions of the information that forms the basis of all life, it is possible that no substitute goods or processes can exist for those granted monopoly protection." In JACKSON, Brian A. Innovation and Intellectual Property: The Case of Genomic Patenting. Journal of Policy Analysis and Management, vol. 22, no. 1, Maio/2003, p. 6.
} 
industrial, de comercialização de um produto ou serviço, de seu signo distintivo, de obra literária, artística ou cientifica." ${ }^{, 63}$

A patente traz também ao seu titular uma vantagem competitiva em seu mercado de atuação por garantir, de forma lícita, a exploração econômica de determinada tecnologia sem concorrência direta, na medida em que exclui terceiros de tal atividade sem que isso lhes cause prejuízos diretos - haja vista que tais tecnologias sequer estariam ao seu alcance, não houvessem sido desenvolvidas. Pode ainda representar fonte de renda adicional para a empresa titular da patente (royalties) que passe a atender outros mercados, sem ter de realizar novos investimentos diretos (licenciamento) ${ }^{64}$.

Tal vantagem garantida pelo Estado deve ser vista como um estímulo aos agentes de mercado em buscar sempre novas tecnologias patenteáveis, o que por consequência direta trará um ambiente de maior competitividade e produtividade.

Neste mesmo sentido, GUISE entende que

\begin{abstract}
"o poder de mercado conferido por meio das patentes e os beneficios que dela decorrem constituem um dos elementos essenciais do regime jurídico de proteção da propriedade intelectual, pois compensam o inventor financeiramente e o incentivam a produzir mais, o que é positivo para a sociedade como um todo" ${ }^{\circ 5}$.
\end{abstract}

Não fosse assim, todos os esforços, tempo dispendido e recursos financeiros aplicados - características estas que se mostram acentuadas no âmbito dos desenvolvimentos biotecnológicos - não seriam recompensados ou recuperados, especialmente em razão de terceiros que poderiam oportunamente se beneficiar de tal invento, o que certamente desencorajaria o desenvolvimento tecnológico ${ }^{66}$. Por isso,

${ }^{63}$ BARRAL, Welber; PIMENTEL, Luiz Otávio. 2007. Direito de Propriedade Intelectual e Desenvolvimento. In: BARRAL, Welber; PIMENTEL, Luiz Otávio. Propriedade Intelectual $e$ Desenvolvimento. Florianópolis: Boiteux, 2007, p. 12.

${ }^{64}$ BARBIERI, José Carlos, ÁLVARES, Antonio Carlos Teixeira. Estratégia de Patenteamento $e$ Licenciamento de Tecnologia: Conceitos e Estudo de Caso, Revista Brasileira de Gestão de Negócios, v. 7, n. 17, p. 58-68, 2005.

${ }^{65}$ GUISE, Mônica Steffen. Comércio Internacional e Propriedade Intelectual. In: BARRAL, Welber; PIMENTEL, Luiz Otávio. Propriedade Intelectual e Desenvolvimento. Florianópolis: Boiteux, 2007, p. 48.

66 "If patents did not protect against independent duplication, an inventor who had spent enormous sums to be the first to discover some useful new idea might find himself unable to recoup his costs because someone else, working independently toward the same goal, had duplicated his discovery within weeks or months after 
mostra-se como um incentivo justo e necessário para que se busquem os necessários investimentos destinados a tais pesquisas, importância esta que se acentua no âmbito biotecnológico em razão de sua dinâmica.

Sob um outro prisma, esta situação somente se mostra socialmente desejada ou relevante à medida em que permite a divulgação de tais invenções pela ampliação do acesso e intercâmbio dessas informações, porquanto possibilita a continuidade do desenvolvimento técnico-científico dela originada. Ora, não é conveniente aos interesses da sociedade que as invenções permaneçam indefinidamente sob o controle exclusivo de pequeno número de agentes econômicos, que poderão se organizar de forma a deter o controle econômico de tal objeto e assim explorá-lo abusivamente, em detrimento da coletividade.

Portanto, uma forma de proteção que permita a remuneração do trabalho intelectual de forma justa - e, consequentemente, atraia os necessários investimentos que o viabilizarão - deve se dar de modo precário, sob pena de se inviabilizar o atingimento de seu objetivo primário, que é o acesso à informação de forma a permitir uma contínua evolução tecnológica, que por sua vez deverá promover o desenvolvimento socioeconômico da nação.

A este respeito, CERQUEIRA reconhece que a invenção deve ser protegida por determinado período de tempo e, uma vez expirado referido prazo, o objeto da invenção deve recair em domínio público, seguindo a natureza dos objetos imateriais "destinados a abandonar, após algum tempo, a esfera da personalidade para se tornarem de uso comum" ${ }^{\circ 7}$.

Todos esses vieses que justificam a importância da tutela jurídica patentária envolvem uma conjugação de esforços e interesses complementares; contudo, todos eles devem convergir para o atingimento de um objetivo maior, de caráter social e econômico. Por tal motivo, BARBOSA, ao citar Robert A. Choate e William Francis, considera que a concessão do privilégio da patente se apresenta como um ato de tripla natureza:

he made it. Patent law prevents such disappointments but at the same time, of course, fosters patent races and the rent-seeking costs that such races can impose" (LANDES; POSNER, op. cit., p. 296).

${ }^{67}$ CERQUEIRA, op. cit., p. 197. 


\begin{abstract}
"Por ser uma recompensa conferida ao inventor para sua invenção passada, é um ato de justiça. Como um incentivo aos esforços futuros, é um ato da órbita da política pública.
\end{abstract}

Como uma concessão da proteção temporária no uso exclusivo de uma invenção particular, sob condição de sua publicação imediata e eventual entrega ao público, é um acordo entre o inventor e o público no qual um cede algo ao outro para que receba aquilo que é concedido para ele" 68

Por isso, somente poderá ser objeto de proteção capaz de restringir sua exploração econômica por terceiros aquele objeto que se refira a soluções técnicas inéditas que possuam aplicação prática e sejam decorrentes exclusivamente da intervenção humana transformadora. Tais transformações técnicas originadas do intelecto humano deverão ser dotadas de traços e características substancialmente marcantes em relação a objetos e resultados previamente existentes, que seriam impossíveis de ser verificadas ou reproduzidas naturalmente. Caso contrário, não existiria contexto favorável capaz de justificar a proteção patentária, pelo simples fato de que inexistiria o interesse social a ele vinculado.

Desta forma, delineados tais aspectos e objetivos que se busca atingir por meio da proteção patentária, passa-se a uma análise técnica a respeito da natureza de tal mecanismo, bem como dos seus pressupostos autorizadores. Isso será feito com base no sistema jurídico nacional atualmente vigente, que envolverá a aplicação deste conceito mais tradicional e clássico de patentes às invenções na área da engenharia genética, setor de vanguarda que possui diversas peculiaridades e ainda não encontra amparo em um arcabouço jurídico pátrio suficientemente coeso e consistente. Por tal motivo, elementos originados de outras jurisdições que possuem relação com o presente estudo serão também aqui considerados, a partir dos resultados obtidos da análise de direto comparado realizada no Capítulo 5.

A partir daí serão interpretados e construídos os meios pelos quais o sistema de patentes atual poderia justificar a proteção dos desenvolvimentos biotecnológicos

\footnotetext{
${ }^{68}$ BARBOSA, Denis Borges. Tratado da Propriedade Intelectual, vol. II. Rio de Janeiro: Editora Lumen Juris, 2010, p. 1102.
} 
originados do avanço da engenharia genética, para que - no Capítulo seguinte - sejam avaliadas as consequências e resultados advindos de tal proteção e, por conseguinte, se eventuais ajustes/modificações na atual legislação se mostram cabíveis e pertinentes a fim se definir a extensão e medida exata de sua proteção.

\subsection{Conceito e fundamento de validade das patentes}

As patentes devem ser entendidas como títulos de propriedade temporária sobre uma invenção ou modelo de utilidade. Referem-se, basicamente, a soluções técnicas para problemas técnicos práticos ${ }^{69}$, em que figuram criações originadas da intervenção humana como elementos centrais. Tais criações possuem caráter técnico e compreendem operações mentais/racionais, vinculadas à transformação da natureza, fazendo surgir uma coisa que anteriormente nela não existia.

Pode assim ser considerada uma permuta entre o Estado e o inventor, por meio da qual este revela todo o conteúdo técnico da matéria objeto de proteção (ao invés de mantêla em segredo), recebendo - em contrapartida - o direito de excluir/impedir quaisquer terceiros da exploração de tal objeto durante determinado período de tempo, trazendo ao detentor da patente vantagem competitiva em seu ramo de atuação.

Em razão de tal característica, as patentes impedem que agentes econômicos, não onerados pelos custos decorrentes da pesquisa e desenvolvimento do objeto da patente, explorem economicamente a tecnologia desenvolvida (ainda que tenham chegado à mesma solução técnica por vias independentes), ou contribuam para que outros a explorem de forma indevida, respeitados os limites legais apontados acima ${ }^{70}$.

O fundamento do sistema de patentes brasileiro está definido no artigo $5^{\circ}$, inciso XXIX, da CF/88, e corroborado pelo artigo $2^{\circ}$, da LPI, segundo os quais devem ser atendidos o interesse social e o desenvolvimento econômico e tecnológico do país para que seja assegurado privilégio patentário. Por essa razão, BARBOSA esclarece que a

\footnotetext{
69 “Já as ideias inventivas industriais (invenções) são soluções (técnicas), que utilizam meios técnicos, para resolver problemas técnicos e, por isso, também práticos, tendo em vista a satisfação, directa ou indirecta, de necessidades humanas" (MARQUES, op. cit. p. 29).

${ }^{70}$ Já o uso não comercial - como aquele para fins científicos - não configura violação aos direitos do titular da patente.
} 
propriedade intelectual é ainda mais rígida do que a propriedade tradicional, pois no Brasil ela só pode ser protegida quando atendidos tais objetivos:

\begin{abstract}
"Nota-se aqui que essa constituição de direitos exclusivos é diversa do da propriedade tradicional. Nesta, a relação se ancora até em estamentos préjurídicos, enfatiza a proteção dos interesses próprios do titular, apenas condicionados à função social; na propriedade intelectual, e especialmente nas patentes, a propriedade nasce não sob contenção, mas por inspiração $e$ determinismo do interesse plúrimo" 71
\end{abstract}

Assim, para que se encontre inserida no âmbito de proteção patentária, o objeto ou processo desenvolvido tecnicamente pelo homem deve atender, primeiramente, o interesse da coletividade, sendo este um "conceito abrangente no qual se acham contidos o interesse social e o desenvolvimento tecnológico e econômico do país ",72.

A propriedade conferida pelas patentes não é sobre o objeto da criação em si: ela se refere ao direito de excluir terceiros do direito de exploração econômica de tais objetos protegidos pela via patentária; trata-se, portanto, de direito negativo com eficácia erga omnes. E os principais direitos decorrentes de patentes de invenção ou de modelo de utilidade são os seguintes, de acordo com a $\operatorname{LPI}^{73}$ : (a) direito de impedir terceiros de

\footnotetext{
${ }^{71}$ BARBOSA, 2010, op. cit. p. 1102.

72 BARBOSA, 2010, op. cit., p. 1103.

73 "Art. 42. A patente confere ao seu titular o direito de impedir terceiro, sem o seu consentimento, de produzir, usar, colocar à venda, vender ou importar com estes propósitos:

I - produto objeto de patente;

II - processo ou produto obtido diretamente por processo patenteado.

$\S 1^{\circ}$ Ao titular da patente é assegurado ainda o direito de impedir que terceiros contribuam para que outros pratiquem os atos referidos neste artigo.

$\S 2^{\circ}$ Ocorrerá violação de direito da patente de processo, a que se refere o inciso II, quando o possuidor ou proprietário não comprovar, mediante determinação judicial específica, que o seu produto foi obtido por processo de fabricação diverso daquele protegido pela patente.

(...)

Art. 44. Ao titular da patente é assegurado o direito de obter indenização pela exploração indevida de seu objeto, inclusive em relação à exploração ocorrida entre a data da publicação do pedido e a da concessão da patente.

$\S 1^{\circ}$ Se o infrator obteve, por qualquer meio, conhecimento do conteúdo do pedido depositado, anteriormente à publicação, contar-se-á o período da exploração indevida para efeito da indenização a partir da data de início da exploração.

$\S 2^{\circ}$ Quando o objeto do pedido de patente se referir a material biológico, depositado na forma do parágrafo único do art. 24, o direito à indenização será somente conferido quando o material biológico se tiver tornado acessivel ao público.

$\S 3^{\circ} \mathrm{O}$ direito de obter indenização por exploração indevida, inclusive com relação ao período anterior à concessão da patente, está limitado ao conteúdo do seu objeto, na forma do art. 41."

(...)

“Art. 61. O titular de patente ou o depositante poderá celebrar contrato de licença para exploração.
} 
produzir, usar, colocar à venda, vender ou importar produto que seja objeto de patente, ou produto obtido diretamente por processo patenteado (artigo 42, I e II); (b) direito de impedir terceiros de contribuir para que outros pratiquem os atos indicados acima (artigo $42, \S 1^{\circ}$ ); (c) direito de ceder ou licenciar os direitos patentários a terceiros, a título oneroso (mediante pagamento de royalties) ou gratuito (artigo 61); e (d) direito de pleitear indenização pela exploração indevida do bem (artigo 44).

A proteção conferida por patentes no Brasil se restringe ao território nacional, e somente é assegurada após o depósito de pedido de patente no Instituto Nacional de Propriedade Industrial (INPI). Contudo, por meio de acordos de cooperação internacionais, é atualmente possível se assegurar a prioridade do invento em outras jurisdições por meio de extensões que podem ser requeridas durante determinado período, contados de seu depósito inicial.

O prazo de vigência de patentes de invenção é atualmente de 20 anos contados da data do depósito do pedido de patente, e o prazo das patentes de modelo de utilidade, por sua vez, será de 15 anos da data do depósito do pedido ${ }^{74}$. Tais prazos passaram a vigorar com a entrada em vigor da LPI em 1996, e estão alinhados com os prazos mínimos previstos no TRIPS - incorporado ao ordenamento jurídico pátrio ${ }^{75}$.

Diversas são as dificuldades relacionadas às patentes biotecnológicas à luz do direito brasileiro, especialmente no que tange às restrições legais a ela relacionadas - seja no controle prévio, seja no controle a posteriori acerca da pertinência de aplicação da tutela patentária a invenções afetas a tal área.

Relativamente ao controle prévio, a lei prevê expressamente determinadas categorias de objetos e processos - dentre os quais se destacam alguns relacionados ou inseridos no âmbito da biotecnologia - que são excluídas de seu âmbito de proteção. É o

Parágrafo único. O licenciado poderá ser investido pelo titular de todos os poderes para agir em defesa da patente."

${ }^{74} \mathrm{Cf}$. art. 40, parágrafo único da LPI o "prazo de vigência não será inferior a 10 (dez) anos para a patente de invenção e a 7 (sete) anos para a patente de modelo de utilidade, a contar da data de concessão, ressalvada a hipótese de o INPI estar impedido de proceder ao exame de mérito do pedido, por pendência judicial comprovada ou por motivo de força maior. ",

${ }_{75}$ Para informações mais detalhadas a respeito do TRIPS, vide Capítulo 5.2.3. 
que dispõe o artigo 10 da LPI, ao convencionar que não serão considerados invenções ou modelos de utilidade, dentre outros, o seguinte:

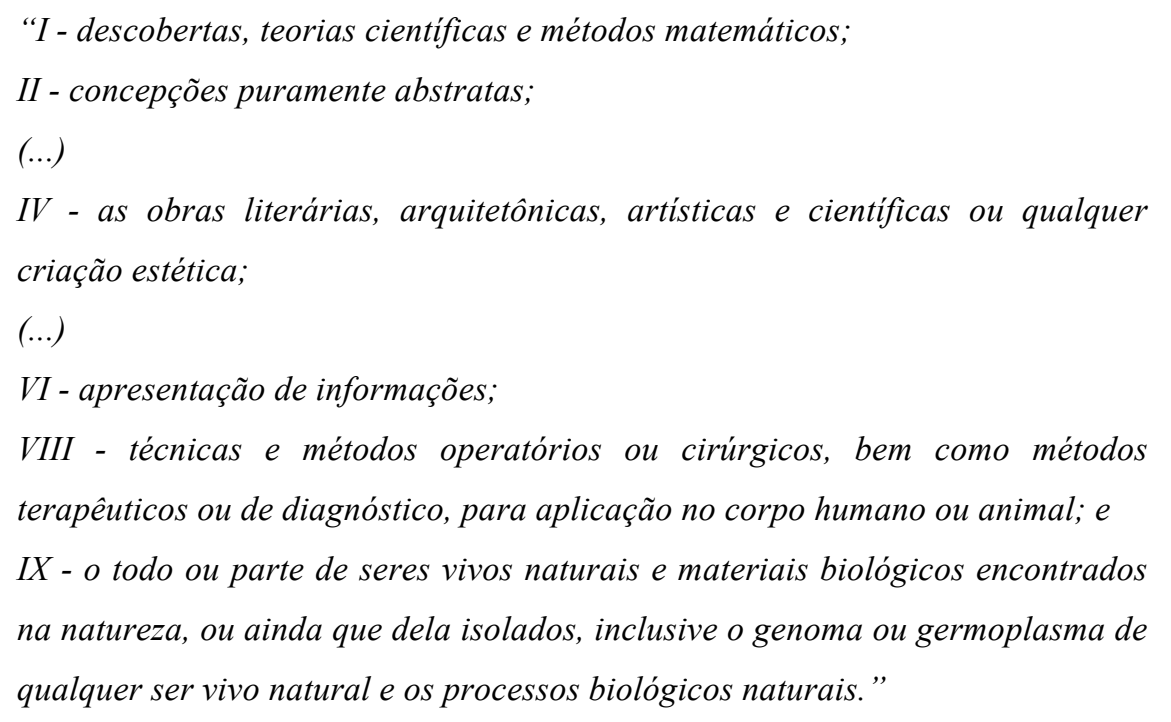

Para aquelas invenções biotecnológicas que são a priori admissíveis (por não se enquadrarem em qualquer das hipóteses acima listadas), deverão ainda passar no teste de patenteabilidade tradicional, que envolve a verificação de critérios autorizadores da concessão patentária (novidade, atividade inventiva e aplicação industrial), que serão discutidos no Capítulo 3.5, a seguir.

Um primeiro e importante aspecto que envolve críticas a respeito da possibilidade de patenteamento dos genes humanos reside na diferenciação terminológica entre os termos "descoberta" e "invenção", conceitos estes que transitam e interferem, de modo decisivo, tanto na discussão relativa ao pressuposto da novidade quanto da atividade inventiva que devem estar presentes nos objetos que os resultados da engenharia genética buscam tutela jurídica.

Há entendimentos no sentido de que apenas há descobertas nessa seara (nunca invenções), sob o argumento de que apenas envolveria (re)combinação de materiais préexistentes ou o isolamento de substâncias que já ocorrem na natureza. Nada obstante, especificamente com relação aos genes, o conteúdo informacional contido naqueles naturalmente ocorrentes não seria alterado pela sua extração/sintetização para aplicação de forma útil. E, ato contínuo, os desenvolvimentos biotecnológicos não seriam elegíveis para 
se tornarem objeto de proteção de patentes por não cumprirem o requisito da novidade e/ou da atividade inventiva, respectivamente.

Não obstante, sendo tais produtos e processos biotecnológicos originados de fenômenos e/ou produtos da natureza, mas que por outro lado não têm condições de ocorrerem espontaneamente, a imprescindibilidade da intervenção humana figura também como condição de sua existência. Neste mister, apenas a título argumentativo, importa ainda lembrar que toda a invenção deriva, obviamente, de produtos previamente existentes na natureza, o que destaca a subjetividade do conceito - que, por conseguinte, deve ser avaliado à luz do contexto em que se insere, em especial no que diz respeito às inovações biotecnológicas $^{76}$.

A engenharia genética atual é marcada por formas de intervenção humana que independentemente do seu grau de criatividade - são capazes de desenvolver processos e produtos novos em relação àqueles encontrados em sua forma natural, na medida em que suas aplicações e resultados práticos/úteis somente são verificados a partir de um desenvolvimento técnico originado da atividade intelectual humana, seja ela em maior ou menor grau. Portanto, importante avaliar qual seria a relevância do grau de criatividade em relação ao objeto que se pretende proteger, ante a subjetividade de que se reveste o termo "invenção" e outros aspectos correlatos, que deverão ser considerados de forma sistematizada e à luz do princípio teleológico buscado pela $\mathrm{CF} / 88$.

Nada obstante, um aspecto de extrema importância à luz do escopo e limitação do objeto da patente que se pretenda buscar no contexto da engenharia genética diz respeito ao âmbito de incidência do requisito da aplicação industrial (e também da utilidade, por via reflexa), dado que um mesmo processo ou objeto biológico pode levar a diversos produtos distintos e com aplicações e resultados também distintos. Como visto, um mesmo gene humano poderá resultar em diferentes aplicações e funções práticas), e que podem ter sido desenvolvidos de modo independente e autônomo, não necessariamente decorrentes de um determinado objeto biotecnológico previamente patenteado.

\footnotetext{
${ }^{76}$ Este assunto será oportunamente retomado no Capítulo 3.5.4.
} 
Por fim, importante ressaltar que a proteção patentária que confere o direito de excluir terceiros da exploração econômica de seu objeto não é suficiente, por si só, para que o titular de tal inovação biotecnológica possa beneficiar-se dos potenciais resultados econômicos daí advindos. Pode haver a necessidade de um controle a posteriori que poderá impedir até mesmo o titular de uma invenção que seja aprovada no teste de patenteabilidade por demonstrar atingimento a todos os requisitos necessários, especialmente em se tratando de invenções relacionadas à área da engenharia genética e suas aplicações na área da saúde.

Refere-se aqui àqueles objetos (processos e produtos) que, muito embora se qualifiquem como patentes à luz da legislação aplicável, são por esta excluídos do âmbito de proteção em razão de aspectos políticos, sejam eles motivados por questões de ordem econômica, social ou moral.

E, por fim, há também análise de ordem regulatória a ser considerada neste contexto: o artigo 229-C, inserido à LPI por meio da Lei no 10.196/2001, estabelece que a concessão de patentes para produtos e processos farmacêuticos dependerá da aprovação prévia da Agência Nacional de Vigilância Sanitária (ANVISA), assunto este que também será discutido oportunamente neste Capítulo.

\subsection{Classificação das patentes e aplicação em âmbito biotecnológico}

Quanto aos tipos de patentes, podemos caracterizá-las como patentes de produto ou de processo em razão da maneira pela qual a solução técnica venha se apresentar, desde que em ambos os casos sejam cumpridos os requisitos de patenteabilidade previstos na LPI, e não estejam excluídos do âmbito de sua proteção (artigo 10) ou que se incluam na categoria das invenções que por opção legislativa não podem ser patenteadas (artigo 18).

Em linhas gerais, as patentes de produto referem-se a objetos físicos determinados, enquanto as patentes de processo dizem respeito aos meios ou métodos utilizados para se alcançar um determinado resultado técnico. Isso quer dizer que a patente de produto diz 
respeito à exclusividade de uma matéria física propriamente dita $^{77}$, independentemente da forma pela qual seja produzido, e a patente de processo irá proteger o meio de produção de determinado objeto, porém não necessariamente o objeto em si.

Por vezes, é possível também que uma patente de produto seja decorrente da aplicação de um processo determinado e específico, especialmente quando se trata de objetos patenteáveis na área da biotecnologia, estando intimamente relacionados os processos e produtos químicos resultantes. Segundo CORREA, esta forma de proteção estende aos processos a mesma tutela conferida aos produtos deles decorrentes ${ }^{78}$.

A classificação de invenções enquanto "processo" e "produto" dos genes na área biotecnológica é de grande dificuldade, especialmente quando lhes é aplicado o mesmo raciocínio utilizado para as invenções tradicionais e mecânicas. Deve-se sempre levar em consideração que a biotecnologia deve ter um tratamento diverso, notadamente em virtude de seu caráter informacional já delineado oportunamente.

Isso quer dizer que o gene, se por um lado pode ser entendido como um "produto" de natureza química, por outro pode também ser considerado um conjunto de instruções que levam a um determinado resultado - o que poderia caracterizar um processo. Neste sentido, interessa trazer entendimento de FELDMAN a respeito:

\begin{abstract}
"Analogies between mechanical and biological inventions are always risky given the vast differences between the two realms. Consider the basic problem of framing genes in terms of either a product or a process, two basic categories developed in relation to mechanical inventions. Genes are sequences of nucleotides that operate as a set of instructions for carrying out some function in the body. We would normally think of a set of instructions as a process, that is, a
\end{abstract}

\footnotetext{
77 “Vimos, anteriormente, que a patente concedida para a invenção de novo produto assegura ao inventor o direito exclusivo de fabricá-lo e de impedir que terceiros o fabriquem, por diverso que seja o processo ou meio empregado na sua fabricação. Não importa, portanto, que o processo seja diferente do empregado pelo concessionário da patente, nem que seja privilegiado: enquanto estiver em vigor o privilégio concedido para o produto, a fabricação deste, sem autorização do titular da patente, constitui delito." (CERQUEIRA, João da Gama, "Tratado da Propriedade Industrial”, 2a ed., vol. 1. Revista dos Tribunais, pp. 546-547).

78 "la tendencia de los países industrializados, su reclamo a los países en desarrollo y las soluciones propuestas por la OMPI apuntan a extender en todos los casos la protección del procedimiento al producto obtenido con aquél. Si bien no idénticos, los efectos de tal extensión son comparables a los derivados de la tutela del producto mismo, con sus consecuencias restrictivas sobre la competencia, el acceso a los productos y la elevación de los precios cargados a los usuarios y consumidores."(CORREA, Carlos. Patentes y Biotecnología: opciones para América Latina. Buenos Aires: Revista del derecho industrial. Ano 12, no 34, Jan./Abr. 1990, p. 42)
} 
method of doing something, rather than as a tangible product. Genes, however, are as concrete and tangible as any machine we might build. It is almost as if one could create a construction manual that operated on its own. Would we treat it as a process or a product?

It takes a certain degree of mental gymnastics to contemplate a thing whose nature is, to some extent, both that of a process and that of a product. The challenge is even greater when that thing must be described in abstract terms in a patent application. It is not surprising that we have run into some difficulties, and those difficulties are exacerbated in the field of personalized medicine when the invention combines genes with computer-related inventions." ${ }^{79}$

Esta importante peculiaridade dos genes, quando aplicados ao âmbito da engenharia genética, tem levado e justificado grande parte da concessão de proteção patentária sob a modalidade de "produtos-por-processo".

A este respeito, importa trazer à baila decisão paradigmática do Technical Board of Appeal do Escritório de Patentes Europeu (EPO), datada de 1984, ao tratar da diferença entre o patenteamento de "products-by-process" e de processos em $\mathrm{si}^{80}$, reconhecendo a validade desta modalidade de proteção patentária.

7. Inventions fall either into the category of products, e.g. articles, devices or materials, or of processes, e.g. methods of preparing a product, or using an article, or obtaining a result. Nevertheless, the invention defined in the claims for products or for processes must all be novel, inventive and industrially applicable according to Article 52(1). Whilst a process may well be novel and deserves full protection in views of its inventiveness, the same may not be true for its product if that is known or obvious in the light of the state of the art. Notwithstanding this, the special protection provided by Article 64(2) EPC extends even to products which are not themselves inventions. According to the submissions of the appellants, the protection provided by "product-by-process" claims should go beyond the limits of "direct products" in Article 64(2) and ought to be equal to that enjoyed by products which are claimed per se, with no restriction to the details of their preparation. This, irrespective of the fact that

\footnotetext{
${ }^{79}$ FELDMAN, Robin. Whose body is it anyway? Human cells and the strange effects of property and intellectual property law. Stanford Law Review, vol. 63, 2011, p. 1386

${ }^{80}$ Disponível em: http://www.epo.org/law-practice/case-law-appeals/recent/t820150ex1.html. Acesso em: 20/11/2014.
} 
the product protected in this manner may not represent an invention at all, as such.

8. The Guidelines for Examination in the EPO (C-III 4.7b) allows claims for products defined in terms of a process of manufacture provided the products themselves fulfil the requirements for patentability. This may well be the only way to define certain natural products or macromolecular materials, of unidentified or complex composition, which have not yet been defined structurally. Nevertheless before such claims are allowable their patentability, as products must be established since such definition is in lieu of the normal definition by structure.

\section{E continua, citando outros casos decididos pelo board da EPO:}

"10. An earlier decision of the Board already established that "the effect of a process manifests itself in the result, i.e. in the product in chemical cases, together with all its internal characteristics and the consequence of its history of origin, e.g. quality, yield and economic value". ("Gelation/Exxon" T 119/82, 12.12.1983). Although problems may be recognised in processes known in the state of the art which are then removed by appropriate modifications or by an altogether different approach, the effect of such measures en route ultimately manifests itself in the technical and economic characteristics of the product, the real purpose of the exercise. Whilst some features of such end-effects may be drawn into the definition of the process for reasons of clarity and of conciseness, the product is in consequence of the invention, without being the invention itself, which is rather the novel interaction represented by the process in such cases. Any attempt to claim the in itself non-inventive product by means of product-byprocess claims is claiming the mere effects instead. Whilst reliance on the provisions of Article 64(2) EPC may nevertheless provide protection beyond the invention in processes leading to known or patentable products alike, this should not be afforded for both kinds of product themselves on the same footing, irrespective of their character. This must therefore be rejected as unjustified and contrary to the requirements of Article 52(1) and 84 EPC. The Board takes the view that in order to minimise uncertainty, the form for a claim to a patentable product as such defined in terms of a process of manufacture (i.e. "product-byprocess claims") should be reserved for cases where the product cannot be satisfactorily defined by reference to its composition, structure or some other testable parameters." (grifos nossos) 
Muito embora o produto novo obtido por meio da aplicação de um processo que não cumpra os requisitos autorizadores da proteção patentária, este mecanismo tem sido utilizado nas reivindicações patentárias como forma de se estender a proteção conferida ao produto ao processo do qual este se originou.

Nada obstante, o estudo da proteção das patentes no âmbito da engenharia genética humana está intimamente relacionado à questão de novos usos e aplicações relacionados a objetos e processos já previamente existentes. A nova aplicação de uma patente pode se referir tanto a um produto quanto a um processo, sendo conhecida por "patente de uso", e tem lugar quando dele se extrai resultado prático ou função novos, desde que verificadas a atividade inventiva e um ato criativo humano ${ }^{81}$.

Em que pese inexista previsão expressa a respeito da possibilidade de patentes de uso no direito brasileiro, pode-se dizer que tal situação está atrelada ao fato de que qualquer invenção dependerá, sempre, de uma intervenção humana - seja ela de produto ou de processo - porquanto as meras “descobertas" não se qualificam como patenteáveis ${ }^{82}$.

Além do mais, como já se pôde verificar, o conteúdo informacional inerente aos genes pode ser considerado informação de base capaz de gerar inovações distintas no ramo da engenharia genética, de forma não subordinada, o que pode justificar a importância de uma tutela jurídica que seja baseada nas aplicações práticas declinadas pelos inventores em suas reivindicações, e cujo âmbito de proteção seja a ela circunscrita ${ }^{83}$.

Vê-se, portanto, que tais conceitos se mostram de grande importância para fins de se atribuir a extensão e limites capazes de balancear uma difícil equação no que tange à proteção patentária como forma de fomento aos desenvolvimentos biotecnológicos: o desestímulo que se pode originar de um ambiente desprovido de qualquer tutela jurídica aos desenvolvimentos na área genética, em contraposição à restrição de acesso aos genes

\footnotetext{
81 “A par das patentes de produto e processo há que se distinguir a invenção que consiste de uma nova aplicação de um produto ou processo (ou patente de uso). A nova aplicação é patenteável quando objeto já conhecido é usado para obter resultado novo, existente em qualquer tempo a atividade inventiva e o ato criador humano. Trata-se pois de uma tecnologia cuja novidade consiste na 'relação entre o meio e o resultado', ou seja, na função. Assim, por exemplo, o uso de um corante já conhecido como inseticida - o DDT" (BARBOSA, 2010, op. cit., p. 1272).

${ }^{82}$ A respeito das patentes de segundo uso, vide Capítulo 4.3.2.1.

${ }^{83}$ Este assunto é tratado no Capítulo 4.
} 
humanos, assim entendidos como informações de base para ulteriores desenvolvimentos tecnológicos. São esses os aspectos que se passa a mais detidamente analisar em seguida.

\subsection{Condições de patenteabilidade}

Ante o quanto acima discutido, a patente, para que seja regularmente concedida, deverá cumprir alguns requisitos legais que justifiquem sua proteção. Neste sentido, podese afirmar ser internacionalmente ${ }^{84}$ reconhecido que determinadas condições cumulativas deverão ser verificadas, a saber: a invenção deve ser nova, não óbvia e possuir aplicação industrial.

Importante considerar, ainda, o critério da utilidade, que está presente em algumas jurisdições e parece possuir certo grau de relevância na análise de reivindicações de patentes biotecnológicas, como já vem sendo ventilado.

No Brasil, os requisitos para a patenteabilidade de invenções estão previstos no artigo $8^{\circ}$ da LPI, e são os seguintes: (a) a novidade, estabelecendo que a invenção não poderá estar compreendida no estado da técnica; (b) a atividade inventiva, ou seja, não deve decorrer de maneira evidente ou óbvia do estado da técnica; e (c) aplicação industrial, segundo a qual é preciso que a invenção possa ser utilizada ou produzida industrialmente.

Segundo a lei brasileira, ainda que preenchidos os requisitos acima, não serão patenteáveis as invenções ou modelos de utilidade que: (a) forem contrários à moral, aos bons costumes, à segurança, à ordem e à saúde pública; (b) envolverem matérias ou métodos resultantes da transformação do núcleo atômico; ou (c) envolverem o todo ou parte de seres vivos, com exceção dos microrganismos transgênicos que atendam aos três requisitos de patenteabilidade e não sejam mera descoberta ${ }^{85}$.

De acordo com a atual intepretação conferida pelo INPI a tais requisitos aplicados às invenções na área da biotecnologia, pode-se depreender que seriam patenteáveis: (a)

\footnotetext{
${ }^{84}$ Refere-se aqui a diretrizes básicas reconhecidas e aceitas nas mais diversas jurisdições do globo, tendo-se como referência o Acordo sobre os Aspectos dos Direitos de Propriedade Intelectual Relacionados ao Comércio (TRIPS); entretanto, há diversas nuances e especificidades que devem ser consideradas e respeitadas, conforme legislações locais.

${ }^{85}$ A esse respeito, vide o art. 18 da Lei ${ }^{\circ}$ 9.279/1996.
} 
vetores, devidamente descritos, quanto às sequências nucleotídicas naturais neles compreendidas; (b) composições que contenham material genético ou sequências de aminoácidos ou vírus, desde que sejam composições (itens 2.6.1 e 2.5.2, Diretrizes para o Exame de Pedidos de Patente nas áreas de Biotecnologia e Farmacêutica); (c) composições contendo extratos, moléculas, substâncias ou misturas obtidas ou produzidas de vegetais, animais ou microrganismos naturais; (d) processos de extração/isolamento; (e) processos de produção de plantas e animais geneticamente modificadas. Os microrganismos mutantes também são patenteáveis, desde que sejam estáveis e reproduzíveis (de acordo com o item 2.13.6 das Diretrizes) $)^{86}$.

De outro lado, segundo essas mesmas diretrizes do INPI, não poderiam ser objeto de patentes as sequências de nucleotídeos e peptídeos isolados de organismos vivos naturais per se; animais ou plantas e suas partes, ainda que isolados ou resultantes de manipulação humana; extratos, moléculas, substâncias e misturas obtidas de vegetais ou produzidas a partir de vegetais, animais ou microrganismos naturais; e métodos terapêuticos dentre os quais, as terapias gênicas.

Já segundo a Lei 11.105/2005 (Lei de Biossegurança), em seu artigo $6^{\circ}$, incisos II e III, proíbe-se a "engenharia genética em organismo vivo ou o manejo in vitro de ADN/ARN natural ou recombinante, realizado em desacordo com as normas previstas nesta Lei” e "engenharia genética em célula germinal humana, zigoto humano e embrião humano", respectivamente, tipificando as infrações correspondentes como crime, com aplicação de penas de reclusão.

Em primeiro lugar, importante mencionar que o âmbito de aplicação desta lei está adstrito à vertente da engenharia genética relacionada ao emprego de técnicas científicas relacionadas à manipulação de genes. Ou seja, refere-se aos OGMs e seus derivados, que segundo definição dada pelo próprio diploma legal, diz respeito aos organismos cujo material genético tenha sido modificado por alguma técnica de engenharia genética.

86 INPI. Grupo de Trabalho Especial em Biotecnologia Estudo Comparativo dos Critérios de Patenteabilidade para Invenções Biotecnológicas em Diferentes Países, Julho/2007, p. 16. Disponível em: http://www.inpi.gov.br/images/stories/Estudo_Comparativo_dos_Critriosde_Petenteabilidadepara_Invenes_ Biotecnolgicas_em_Diferentes_Pases1.pdf. Acesso em: 10 de Nov. 2014. 
Referida lei procura limitar e regulamentar pesquisas e desenvolvimentos que envolvam a intervenção humana relacionada a meios de clonagem e modificação genética de organismos vivas, especialmente em seres humanos, exceto quando se destinem a pesquisa e terapia.

Na lição de DINIZ, a Lei de Biossegurança relaciona-se à porção da engenharia genética que se refere a:

"uma tecnologia utilizada em nivel laboratorial, pela qual o cientista poderá modificar o genoma de uma célula viva para a produção de produtos químicos ou até mesmo de novos seres, ou seja, de organismos geneticamente modificados (OGM) (Lei $n^{\circ} 11.105 / 2005$, art. $3^{\circ}$, IV e V), cujo impacto poderá produzir efeitos em todas as áreas da sociedade. ${ }^{, 87}$.

Trata, portanto, da proteção:

"[da] identidade e irrepetibilidade genética do ser humano, de cada indivíduo. Indiretamente, tutela-se também a inalterabilidade do patrimônio genético da humanidade. Melhor explicando: a identidade genética do ser humano abarca, como já foi visto, um duplo sentido: por um lado, a identidade do individuo (sua irrepetibilidade); e a inalterabilidade do patrimônio genético da humanidade" ${ }^{\text {} 88}$.

Em que pese a importância de referido diploma legal, o presente estudo não está inserido em seu contexto, de modo que deixamos de explorá-lo de modo mais aprofundado.

\subsubsection{Novidade}

O pressuposto da novidade deve ser sempre apreciado de modo objetivo ${ }^{89}$, não sendo a originalidade de caráter subjetivo suficiente para se conferir direito à proteção pela

\footnotetext{
${ }^{87}$ DINIZ, Maria Helena. O Estado Atual do Biodireito. São Paulo: Editora Saraiva, 2007, p. 397.

${ }^{88}$ PRADO, Luiz Regis; HAMMERSCHMIDT, Denise. A Clonagem Terapêutica e Seus Limites de Permissibilidade na Lei de Biossegurança Brasileira (Lei 11.105/05). Revista jurídica do Ministério Público de Mato Grosso, v. 3, n. 4, p. 105-117, jan./jun., 2008, p. 109-110. Disponível em: http://mpto.mp.br/cint/cesaf/arqs/040908090302.pdf).

${ }^{89}$ Conforme Newton Silveira "em sentido subjetivo, a novidade representa um novo conhecimento para o próprio sujeito, enquanto, em sentido objetivo, representa um novo conhecimento para toda a coletividade"
} 
via patentária. A novidade objetivamente considerada implica dizer que uma invenção somente será nova quando não estiver compreendida no estado da técnica à época de sua proteção $^{90}$.

Os produtos e processos resultantes de uma intervenção humana deverão se distinguir de outros já existentes no estado da técnica, por contarem com características próprias e únicas. Colocando-se de outra forma, a simples aplicação de um conhecimento preexistente (já abrangido pelo estado da técnica) ou que seja uma evolução ordinária de tal acervo técnico, não implica criação nova/original.

A questão da novidade patentária com relação a material biológico assume especial relevância, tendo em vista que o material biológico pode ser encontrado na natureza, via de regra. Claro que exceções podem ser verificadas: em algumas situações a intervenção humana é tão distinta e inovadora que a manipulação genética pode originar materiais biológicos cuja existência seria impossível de ser espontaneamente verificada.

Através da moderna biotecnologia, criam-se novos organismos vivos que, longe de serem considerados meras descobertas ou originados de processos biológicos naturais, nos quais a ação do homem se dá de forma "marginal", mereceriam proteção patentária tal qual as demais criações verificadas em outras áreas tecnológicas.

Resultado de engenharia genética, esses organismos não-naturais quando originam invenções biotecnológicas genuínas, devem possuir um nível de proteção equiparável ao das invenções tradicionais, mecânicas.

Isso se deve ao fato de que o objeto protegido, tal qual a utilidade prática que se lhe atribui, não possui um caráter universal e tampouco deve ser considerado matéria-prima capaz de inviabilizar desenvolvimentos futuros, por se tratar de compostos que sequer existem na natureza. Para tais casos, parece que uma tutela jurídica plena deva ser conferida, o que não mostra ser mais acertado às situações que envolvam os genes

(SILVEIRA, Newton. Propriedade intelectual; propriedade industrial, direito de autor, software, cultivares, 3. ed., rev. e ampl. Barueri: Manole, 2005, p. 9).

90 O conceito de "estado da técnica" deve ser entendido como uma construção jurídica dinâmica, cujo acervo sempre se atualiza; é constituído por tudo aquilo acessível ao público por descrição escrita, por qualquer meio, em qualquer lugar (divulgações efetuadas no mundo todo), até a data do depósito. 
“tratados", mas que em sua forma bruta podem ser encontrados na natureza ${ }^{91}$.

Ressalvada a excepcionalidade dos compostos não-naturalmente ocorrentes, o critério da novidade, no que tange aos genes passíveis de patenteamento em relação a seus respectivos "similares" encontrados espontaneamente na natureza, reside na disponibilidade do material genético de forma diferente daquela existente na forma natural, em condições que não podem ser reproduzidas espontaneamente na natureza.

As invenções biotecnológicas se baseiam na extração (isolamento e purificação) de substâncias naturais dos seus meios nativos ou na sua síntese química laboratorial ${ }^{92}$, sendo tais produtos desconhecidos nesta forma concreta e inexistentes sem que houvesse a intervenção humana direta para gerar tal resultado. Discute-se aqui, portanto, se tais produtos não seriam suficientemente distintos daqueles encontrados na natureza, uma vez que é perfeitamente possível o aproveitamento dos recursos naturais e suas propriedades para se criar novos produtos com aplicações industriais/comerciais distintas.

Embora as sequências de DNA em sua forma nativa e complexa não cumpram o requisito da novidade por serem encontradas espontaneamente na natureza, tal obstáculo é superado pela produção de genes em formas que apenas existem por meio da intervenção humana (genes isolados e purificados extraídos das células, cDNA obtidos sinteticamente em laboratórios, vetores recombinantes). A alteração genética deve fazer surgir um "novo" organismo, "inventado" - equiparável a outro invento. Sob esta perspectiva, isolar e classificar as propriedades de um gene não seria considerada mera descoberta, estando mais próximo de uma invenção ${ }^{93}$.

\footnotetext{
${ }^{91}$ A questão da amplitude da tutela patentária a ser conferida as invenções biotecnológicas será discutida de forma mais aprofundada no Capítulo 4.

92 Relativamente ao isolamento e purificação de genes, vide Capítulo 2.2.3.1, e a respeito da síntese laboratorial de genes, o Capítulo 2.2.3.2.

93 “(...) Patent protection [nos EUA] is not available for abstract ideas constituting disembodied concepts or truths, which are not useful from a practical stand-point standing alone, until reduced to some practical application. However, a process, machine, manufacture or composition of matter employing a law of nature, natural phenomenon, or abstract idea may be patentable even though the law of nature, natural phenomenon or abstract idea employed would not, by itself, be entitled to such protection. For example, a DNA or a polypeptide is not patentable by itself, but a purified or an isolated DNA or polypeptide is patentable; similarly, a microorganism or a plant by itself is not patentable, but a transgenic microorganism or a plant is patentable. Likewise, products of nature, such as vitamins and minerals are also unpatentable in their naturally occurring state. If, however, a product of nature is new, useful, and nonobvious, and has somehow been altered by humans, (e.g., purification, concentration, combination or isolation), it may then be patentable. Accordingly, the altered form of a product of nature (i.e., purified vitamin B12) does not occur in nature and is patentable. Therefore, there is a distinction between a true product of nature and a product
} 
Ou seja, apesar de possuírem uma estrutura similar àquela dos materiais encontrados na natureza, eles são resultado de processo técnico que a natureza não seria capaz de reproduzir sozinha; apenas por existirem previamente na natureza, não estavam disponíveis de forma que pudesse ser utilizada, e isso deve ser motivo suficiente a justificar a novidade. Compartilha deste mesmo entendimento MARQUES, ao tratar do requisito da novidade em patentes genéticas:

"No que tange à novidade dos genes ou das sequências parciais de genes,
embora a consideração da circunstância de a estrutura dessas substâncias ser
idêntica à que exista na Natureza, do simples facto do seu isolamento e
caracterização (através de parâmetros estruturais ou funcionais) - desse quid
até aí desconhecido - deriva a sua novidade, ainda quando o perito na
especialidade pudesse implícita e teoricamente conhecer a sua existência (ou
esta lhe não ser cognoscivel)."

Esse raciocínio foi inicialmente desenvolvido e aplicado aos processos de isolamento e purificação de genes extraídos diretamente da natureza pelo Escritório Americano de Marcas e Patentes (USPTO) e jurisprudência americanos. Entretanto, foi também estendido aos genes sintetizados em laboratório, e com maior evidência, haja vista a sua estrutura química ser materialmente diferente (por não contemplarem em sua sequência de bases os íntrons).

Muito embora mais recentemente este entendimento tenha evoluído nos EUA, passando a ser reconhecido que apenas o DNA sintetizado seria uma invenção - e não mais os genes isolados ${ }^{95}$ - pois não existe no mesmo estado purificado na natureza, tal restrição não se justifica, devendo ser identificada a aplicação técnica dos genes por quaisquer desses meios como fator determinante para se fundamentar-lhes a tutela patentária. Podese entender, assim, que a mera existência de um material em sua forma inseparável na natureza não deve implicar denegação de reivindicação de proteção patente por não ser verificado o requisito da novidade, ou por considerá-la como mera descoberta.

merely derived from nature." (VINAROV, Sara D. Patent Protection for Structural Genomics-related Inventions. Journal of Structural and Functional Genomics, vol. 4, 2003, p. 194).

${ }^{94}$ MARQUES, op. cit., p. 39.

${ }^{95}$ A respeito da mudança de orientação na jurisprudência norte-americana, vide Capítulo 5.3.4.11, que discute o caso Myriad Genetics, recentemente julgado pela Suprema Corte Americana. 
A definição de novidade deve considerar o aspecto da não-acessibilidade, pelo público em geral, de informações relativas ao objeto sob proteção. Assim, caso não estivessem disponíveis informações suficientes quanto à existência do material biológico em sua forma "pura", bem como suas respectivas propriedades e uso, ele atenderia ao requisito de novidade exigido pelo sistema de patentes. Respaldando-se no entendimento acima, os genes humanos que - por qualquer meio ou modo - sejam extraídos de seu ambiente natural e separados de outros compostos químicos, reveste-se da condição necessária para atestação de sua novidade.

E, se tal assertiva se mostra consistente para os genes naturais extraídos do meio em que originalmente se inserem, ainda mais explícita se mostra tal relação quando se discute a aplicação do requisito da novidade aos genes humanos reproduzidos artificialmente em laboratório (cDNA).

Ora, para além de não estar vinculado a outras moléculas e ser de impossível reprodução de forma espontânea, o cDNA é um composto químico cuja estrutura e composição químicas são completamente distintas de gene equivalente que ocorre naturalmente ${ }^{96}$. Como já foi explicitado oportunamente, o cDNA é composto apenas pelas sequências de nucleotídeos que possuem funções biológicas expressas, enquanto os genes naturalmente ocorrentes (mesmo quando extraídos de seu ambiente original) contêm segmentos de nucleotídeos que não desempenham funções aparentes.

Apesar disso, há alegações de que em qualquer dos casos (sejam genes extraídos de seu ambiente natural ou aqueles sintetizados em laboratório), não seria relevante a atuação humana para fins de se determinar a existência de tal critério (o da novidade), uma vez que o conteúdo informacional seria o mesmo. É o que se pode extrair do texto abaixo reproduzido:

\footnotetext{
${ }^{96}$ Segundo Feldman, "cDNA does not normally exist in the human body, and is naturally created only through the operation of certain retroviruses. Transforming normal DNA into CDNA, however, provides a more efficient tool for researchers and health care professionals who wish to study, diagnose, and treat the disease associated with a gene. (...) Another advantage of cDNA over natural DNA is that the shorter length makes many laboratory procedures possible that could not be performed effectively with natural, full-length $D N A$. In other words, the inventors have created an altered version of DNA that is tailored to work in a laboratory setting in a way that natural DNA would not." (FELDMAN, Robin. Whose body is it anyway? Human cells and the strange effects of property and intellectual property law. Stanford Law Review, vol. 63, 2011, p. 1388).
} 
"The mere removal of DNA from its native environment and excision of noncoding regions does not result in any substantial functional difference from naturally occurring DNA or RNA (...) because they maintain identical or very similar characteristics to those found in nature (...) [and] because they realize exactly the same function that genes inserted in their natural environment perform." ${ }^{97}$

Tal entendimento, contudo, não merece amparo, pois parece não distinguir de forma suficiente o gene enquanto "insumo" e enquanto "produto" daí decorrente. A este respeito, importante a distinção de KLUGE, ao esclarecer que o termo gene pode ter dois significados distintos, a saber: o "gene" enquanto matéria, e enquanto código informacional capaz de codificar alguma função biológica apta a produzir resultados novos e úteis para a indústria ${ }^{98}$.

Conquanto forçoso reconhecer-se a existência de uma área "cinzenta" capaz de gerar esse tipo de situação, fato é que as características e funções desempenhadas pelo gene em sua forma natural enquanto unidade integrante de um organismo vivo qualquer, por óbvio, não deve ser protegida; situação completamente distinta é buscar-se aplicação prática e útil a genes fora de seu ambiente natural e que nunca poderiam ser por eles realizadas em sua forma espontânea.

Sob este aspecto, conclui-se pela novidade objetiva do gene originada pela intervenção humana enquanto uma matéria, fisicamente considerada, indispensável para que possa ser aplicado de forma a solucionar um problema técnico. Temática relacionada à questão da novidade em matéria genética, e que será discutida de forma mais aprofundada no Capítulo seguinte, o conteúdo informacional compreendido pelo gene naturalmente ocorrente não deve ser objeto da proteção patentária em si, mas sim o gene "tratado"

\footnotetext{
${ }^{97}$ CARVALHO citado por HOLMAN, Christopher M. Patent border wars: defining the boundary between scientific discoveries and patentable inventions. Trends in Biotechnology, vol. 25, $\mathrm{n}^{\circ}$ 12, Dezembro de 2007, p. 540.

98 "The claim that a gene-in-context is different from a gene-in-isolation is logically flawed. It is based on a confusion between two meanings of the term "gene": once as referring to the material substance that has been isolated from a specific strand of DNA, and once as referring to the code or blueprint that structures the material substance that codes for a particular trait. The gene that is of interest for the purpose of patenting is not the material substance but the blueprint. As biological blueprint, however, it is the same whether it occurs in the context of a strand of DNA or in isolation." (KLUGE, Eike-Henner W. Patenting Human Genes: When Economic Interests Trump Logic and Ethics. Health Care Analysis, vol. 11, no 2, Junho/2003, p. 126).
} 
enquanto composto dotado de capacidade de apresentar uma finalidade/aplicação prática e útil ao ser humano. Isso quer dizer que o resultado da intervenção humana que distinga o gene patenteável do gene natural envolve não apenas a sua forma de apresentação, devendo também estar vinculada a uma aplicação prática que lhe seja atribuída.

A novidade objetiva analisada pela ótica do conteúdo informacional que os genes representam poderia, assim, estar também de alguma maneira vinculada a um resultado prático destinado a satisfazer determinada necessidade humana - muito embora tal aspecto a princípio pareça estar mais afeto à questão da aplicação industrial enquanto norteador de eventual necessidade de demonstração da utilidade do gene que se pretende patentear, o que será tratado a seguir.

Por tudo, a novidade dos genes humanos se mostra consistente nas situações retro assinadas (seja quanto aos genes não-naturais e aos genes naturais sujeitos a alguma forma de intervenção humana que os tornem aptos a produzirem resultado técnico prático e capazes de serem reproduzidos em escala industrial). Ora, claro está que nesta situação os produtos biotecnológicos decorrentes de uma sequência de DNA são distintos dos genes naturalmente ocorrentes, e que tal forma assumida por meio da intervenção humana é necessária para que passe a deles se extrair uma aplicação técnica útil antes desconhecida.

Por outro lado, as patentes de processos não parecem ser uma regra no âmbito das inovações relacionadas à engenharia genética - já que os métodos relacionados à purificação, extração, isolamento e síntese laboratorial de genes humanos são uniformes, rotineiros e automáticos na atualidade. Além do mais, conforme artigo 10, inciso VIII, da LPI, as "técnicas e métodos operatórios ou cirúrgicos, bem como métodos terapêuticos ou de diagnóstico, para aplicação no corpo humano ou animal" são expressamente excluídos do âmbito de proteção patentária.

Neste contexto, os processos biotecnológicos somente poderão ter sua patenteabilidade reconhecida quando atrelados a outros aspectos adicionais que garantam que os processos são aplicações genuínas das leis da natureza, fenômenos naturais e/ou ideias abstratas, e não meios para se monopolizar tais ferramentas de base para futuros desenvolvimentos. O que se pretende neste caso é assegurar a limitação a uma aplicação particular e inventiva de tais recursos, vedando-se assim que simples métodos diagnósticos 
sejam patenteados, sendo necessário mais do que simples coleta, análise e comparação de dados para que um método ou produto genético seja reconhecido como patenteável.

\subsubsection{Atividade inventiva}

A invenção, por sua vez, muito embora não seja conceituada positivamente ${ }^{99}$, deve ser entendida como sendo aquela criação que não decorra de maneira evidente ou óbvia do estado da técnica para um homem médio versado no assunto. A teor do quanto estipula a LPI, o termo "estado da técnica" se refere ao acervo técnico identificável por divulgações realizadas por qualquer meio ou modo, seja no Brasil ou no exterior, e que sempre se atualiza $^{100}$.

Em que pese o quanto acima asseverado, o termo "atividade inventiva" pode ser identificado na própria conceituação de invenção, contida no artigo $8^{\circ}$, da LPI, segundo a qual a invenção contemplará o requisito de atividade inventiva se, considerando o estado da técnica, não for óbvia para um técnico versado na área ${ }^{101}$.

As invenções, para serem patenteáveis, não podem decorrer de meras justaposições de processos, combinações de meios ou órgãos conhecidos, simples mudança de forma, proporções, dimensões ou de materiais, salvo se, no conjunto, o resultado obtido não seja evidente para um técnico no assunto ${ }^{102}$.

\footnotetext{
${ }^{99}$ Salvo em alguns poucos casos de jurisdições que conceituam positivamente o termo "invenção", os sistemas jurídicos tendem apenas a indicar rol taxativo das exceções.

${ }^{100}$ Conforme artigo 11, parágrafo 1, da LPI, "o estado da técnica é constituído por tudo aquilo tornado acessível ao público antes da data de depósito do pedido de patente, por descrição escrita ou oral, por uso ou qualquer outro meio, no Brasil ou no exterior, ressalvado o disposto nos arts. 12, 16 e 17."

${ }^{101}$ Segundo o artigo 13, da LPI, "invenção é dotada de atividade inventiva sempre que, para um técnico no assunto, não decorra de maneira evidente ou obvia do estado da técnica".

102 "The patent application, before a patent is issued, must satisfy specific statutory requirements. The patent application must fully disclose the invention and include at least one claim to the invention. The patent application must provide a written description of the invention in sufficient detail to enable a practitioner in the art to make and use the invention without undue experimentation, and must also describe the best mode (that is, the best way) for practicing the invention. (...) In addition, a claim must meet the statutory requirements of novelty and nonobviousness. In general, novelty requires that a claim not describe an invention which has been described completely by a single prior art reference or event, and nonobviousness requires that a claim not describe an invention which could be described by a combination of prior art references or events" (MEYERS, Thomas C.; TURANO, Thomas A.; GREENHALGH, Duncan A.; WALLER, Patrick R.H. Patent protection for protein structures and databases. Nature Structural Biology, Nov/2000., p. 950) (Grifos nossos).
} 
As inovações desta forma originadas são chamadas por CERQUEIRA de "construções", sendo as mais comuns as seguintes: (a) as modificações de forma, de dimensões, dosagens e proporções; (b) a substituição de materiais; (c) a justaposição ou agregação de órgãos; (d) a junção ou disjunção de elementos conhecidos; (e) as inversões cinemáticas; (f) a inversão da ordem de operações; (g) o transporte de uma indústria para outra; (h) o emprego novo de um elemento conhecido; (i) a substituição de um elemento por outro equivalente ${ }^{103}$.

As inovações dotadas desse caráter construtivo são carecedoras de atividade inventiva por ausência de criação, originalidade de concepção e manifestação do espírito inventivo. Contudo, caso "essas inovações se caracterizarem não, apenas, por um resultado novo ou diferente, mas por efeito peculiar, por uma ação técnica especial, o caso muda de figura e a inovação poderá constituir invenção"104.

O requisito da inventividade (ou não obviedade) distingue assim um trabalho rotineiro, que não envolve habilidade ou capacidade além daquela usualmente inerente a ou exigida de - um técnico no assunto de mediana experiência, daquele que envolva desenvolvimento tecnológico originado de trabalho criativo humano transformador.

Da mesma forma, os avanços evidentes ou óbvios do estado da técnica que podem ser alcançados por uma pessoa média, cuja área técnica lhe seja afeta (simples inovação), não apresentam tal requerimento. Isso quer dizer que a invenção deve resultar de um ato ou procedimento originado de uma intervenção técnica humana, que seja imprevisível ou não óbvia a um técnico que domine o ramo da ciência em que ela se insere.

Trata-se aqui, portanto, da hipótese de aferição de uma operação do intelecto humano que se mostra extraordinária em relação à normalidade das atividades desenvolvidas pelos demais técnicos no assunto, sendo caracterizada por um elemento objetivo e um elemento subjetivo; este refere-se à atividade criativa, e aquele refere-se à criação de uma utilidade (ou incremento daquela anteriormente existente), para satisfação de uma necessidade humana.

\footnotetext{
${ }^{103}$ CERQUEIRA, op. cit., p. 238.

${ }^{104}$ Ibidem, pp. 238-239.
} 
Sobre o conceito de invenção privilegiável, CERQUEIRA ensina que "privilegiável é a invenção que satisfaz aos requisitos legais de que depende a concessão do privilégio. (...) Se existe invenção, aplica-se a lei" ${ }^{\prime 105}$. E sob este aspecto, considera quatro sentidos de invenção: (a) no de faculdade de inventar; (b) no de ato de inventar; (c) do da coisa inventada; e (d) no de achado ou descoberta.

O primeiro deles refere-se à “imaginação criadora, síntese das operações mentais pelas quais o espírito dissocia os elementos conhecidos para associá-los segundo uma ordem diferente, formando novas combinações"106. O segundo diz respeito à ação ou faculdade de inventar. Já o terceiro traz o termo "invenção" como sinônimo de "invento". Por fim, o quarto emprega a palavra de acordo com o Direito Civil pré-Código Civil de 2002, no qual "invenção" tinha o significado de "descoberta" $"$.

O autor afirma que há muita dificuldade em encontrar uma só definição, em função

“(...) da equivocacidade do termo, pois o que se pretende definir como invenção é a coisa inventada, quando a invenção não reside no resultado, mas precisamente no ato, isto é, no exercício das complexas funções a que denominamos imaginação criadora, da qual a coisa inventada não é mais que o resultado ou objeto particular." 108

Sustentar reivindicações de proteção patentária de genes com estrutura similar à daqueles ocorrentes espontaneamente na natureza pela alegação de que eles são resultados da intervenção humana (ao invés de ocorrem naturalmente) pode, à primeira vista, aparentar ser inconsistente, sob o argumento de que as propriedades de um gene (tais como a síntese proteica) não foram inventadas: são inerentes aos próprios genes e ocorrem naturalmente no DNA de um indivíduo.

\footnotetext{
105 Ibidem, p. 209.

${ }^{106}$ Ibidem, p. 210.

${ }^{107}$ Do Código Civil de 1916: "DA INVENÇÃO - Art. 603. Quem quer que ache coisa perdida, há de restituíla ao dono ou legítimo possuidor". "Inventor é o nome que se dá ao indivíduo que encontra o tesouro. (...) Tesouro é o objeto móvel e valioso em relação ao qual desapareceu qualquer direito de propriedade por ter sido enterrado ou escondido, aparecendo depois de uma escavação ou busca, intencional ou casual. A descoberta recebe o nome técnico de invenção ('inventio')" (CRETELLA JÚNIOR, José. Curso de Direito Romano, $18^{\mathrm{a}}$ ed. Rio de Janeiro: Forense, 1995, p. 209-210).

${ }^{108}$ CERQUEIRA, op. cit., p. 216.
} 
À luz de tal entendimento, questiona-se se a obtenção de genes isolados/purificados ou sintetizados em laboratório seria suficiente para representar, por si só, um alcance inventivo capaz de merecer proteção legal. Contudo, as determinadas unidades químicas que compõem os genes em suas formas puras e dotadas de uma aplicação prática não são óbvias por não serem reproduzíveis espontaneamente em seu meio natural e somente podem ser identificadas e ter verificada sua eventual utilidade industrial após a realização de sofisticada pesquisa bioquímica e macrobiológica.

Mais que isso, os genes "puros" cuja possibilidade/viabilidade de proteção ora se analisa não ocorrem de forma espontânea na natureza e não se confundem com estes (os genes nativos). Eles somente são obtidos como resultado de uma atividade humana de natureza técnica, que na prática produz algo que não existia anteriormente na natureza. Neste sentido, as formas isoladas, purificadas e sintetizadas de DNA devem sim ser consideradas invenções humanas, ao invés de mera criação da natureza.

Muito embora seja relevante a aferição do grau de criatividade envolvido na obtenção de determinado produto ou processo ao qual se busque proteção patentária, para conclusão pela verificação ou não de um passo inventivo, no caso das patentes de natureza genética importa que o produto ou processo biotecnológico possua um valor mínimo suficiente para que se reconheça sua existência, donde se destaca o aspecto objetivo da invenção, que reside primordialmente na sua utilidade e aplicação prática.

Neste sentido, muito embora produtos naturalmente ocorrentes, leis da natureza, fenômenos físicos e ideias não sejam privilegiáveis, elas podem ser utilizadas para que se chegue a um resultado decorrente do engenho humano, passível de tutela jurídica patentária, caso dotada de caráter e uso distintos. Tal assertiva é verdadeira não apenas para as invenções biotecnológicas, onde a questão é mais latente e sensível, mas para toda e qualquer patente: todas elas, em maior ou menor grau, são originadas de tais elementos básicos naturais.

O fato de haver uma maior proximidade de referidas "matérias-primas" aos resultados dela originados quando se trata das invenções no ramo da biotecnologia - em especial os genes - em nada deve obstar ou limitar o direito de se reconhecer o valor criativo originado da ação humana que traga um resultado útil capaz de solucionar um 
problema técnico. Apesar de existir uma tênue linha entre "insumo" e "objeto patenteável" quando se discute inovação biotecnológica, deixar-se de conferir o status de invenções aos desenvolvimentos em engenharia genética, por não considerar uma intervenção humana de caráter técnico-científico "de ponta" suficiente para se conferir a proteção patentária, seria desprestigiar e relegar a esfera de menor importância uma das áreas mais promissoras e com maior potencial de geração de aplicações e utilidades práticas que busquem melhoria na qualidade de vida do ser humano - o que parece um contrassenso.

Dessa constatação emerge outro aspecto que também deve ser levado em consideração, de modo a conferir uma interpretação mais ampla ao conceito de "homem médio versado na técnica" no âmbito da engenharia genética. Não se pode ignorar que, além do seu aspecto intelectual, há importantes recursos organizacionais, instrumentais e financeiros que deverão ser disponibilizados para que se permita a realização de P\&D de modo minimamente adequado neste setor do conhecimento. Trata-se de ramo da ciência que envolve tecnologia de ponta, e sua exploração depende de uma coordenação de diversos recursos e vultosos investimentos a fim de que se permita uma estrutura adequada à exploração científica. Além disso, toda esta mobilização deve se dar em um contexto de retornos improváveis e imprevisíveis.

Em que pese tal interpretação extensiva possa extrapolar o âmbito da criação intelectual de caráter meramente técnico-científica como critério necessário à caracterização de uma invenção, tal fato não pode ser ignorado no contexto dos desenvolvimentos tecnológicos inseridos na seara da engenharia genética.

Não é suficiente ter o desejo de inovar caso não exista o investimento necessário que, não raro, é bastante alto, especialmente em tecnologias mais avançadas, de fronteira. Ainda que a ideia inovadora chegue a se concretizar, somente alguns poucos agentes possuirão os recursos exigidos para a produção em massa do invento, o que dificulta a distribuição e a propagação dessa inovação, passos necessários ao atingimento da finalidade social inerente à própria razão de existência do direito patentário. Observando esse fenômeno, SCHUMPETER decidiu mudar o foco construído em "Teoria do Desenvolvimento Econômico", passando, na obra "Capitalismo, Socialismo e 
Democracia", a atribuir o intento inovador primordialmente às grandes indústrias dotadas de centros de $P \& D^{109}$.

Não há, portanto, como relacionar a atividade inventiva exclusivamente à capacidade intelectual especial de determinado profissional: mais do que ideias, são necessárias as oportunidades certas para que o projeto seja levado adiante. Diante disso, forçoso reconhecer-se que não apenas o fator pessoal do técnico que alcança algo extraordinariamente distinto em sua área de atuação se mostra necessário e suficiente à proteção de tais resultados. Diversas influências e fatores presentes no meio e contexto em que se inserem podem ser determinantes para que o espírito inventivo e criador do ser humano floresça e se criem invenções úteis e com aplicação prática.

Sobre esta questão, MARQUES ensina que nos setores de tecnologia de ponta este conceito de "atividade inventiva" deve possuir uma interpretação mais ampla, nos moldes acima alinhavados:

\footnotetext{
"A actividade inventiva - em sectores de tecnologia de ponta, como o das biotecnologias - por vezes, não reside tanto em averiguar o flash de génio, a intuição do inventor relativamente ao especialista médio do sector, quanto em recompensar, com a outorga do direito de patente, os resultados da investigação e desenvolvimento obtidos por grandes equipas de cientistas e precedidos de uma actividade material e intelectual paciente, diligente e repetitiva, em que haja mais suor do que inspiração. A dilucidação do nivel de organização dos meios empresariais postos à disposição da pesquisa e desenvolvimento cientificos - v.g., dotações financeiras precipuamente orçamentadas, duração da investigação, máquinas e maquinismos postos à disposição, o grau de integração das equipas de investigação - talvez possa passar, deste modo, a ser tão importante quanto as características intelectuais e a formação profissional na especialidade."
}

\footnotetext{
109 “A primeira coisa que uma empresa moderna faz, quando sente que pode fazê-lo, é estabelecer um departamento de pesquisas com pessoas que sabem que sua sobrevivência irá depender do sucesso que tiverem na invenção de aperfeiçoamentos." (SCHUMPETER, Joseph Alois. Capitalismo, socialismo e democracia. Rio de Janeiro: Editora Fundo de Cultura, 1961, p. 96). E "Schumpeter (1950) afirmava que o tamanho da firma, ou o seu poder de mercado, determinava positivamente o incentivo à inovação. Firmas com elevado poder de mercado inovariam mais que outras com menos poder." (CORREIA, Eduardo; MOITA, Rodrigo. Gasto em P\&D e Poder de Mercado: Teoria e Evidência para o Brasil. Pesquisa e Planejamento Econômico (IPEA), v. 41, n. 1, abr. 2011, p. 101. Disponível em: http://ppe.ipea.gov.br/index.php/ppe/article/viewFile/1222/1087).

${ }^{110}$ MARQUES, op. cit., pp. 52-53.
} 
Sob esta perspectiva, a análise do estado da técnica deve também ser interpretada de modo mais amplo, englobando também o fato de que o técnico médio não necessariamente dispõe de todos os recursos instrumentais, financeiros e técnicos para o desenvolvimento de trabalhos complexos e que demandam elevados investimentos, como aqueles realizados no âmbito da engenharia genética. $O$ alcance a um determinado desenvolvimento biotecnológico pode ser determinado pelo ambiente em que ele está inserido, e pelas condições que lhe são proporcionadas para a busca do resultado científico pretendido.

Deste modo, conclui-se pela possibilidade de se justificar a existência do critério da atividade inventiva para dar suporte a reivindicações de patentes relacionadas a genes humanos, desde que sua utilização na forma "pura" descreva um resultado prático útil, decorrente de uma associação originada do intelecto humano que não seja óbvia para um técnico versado na área, seja por demandar conhecimentos científicos ou recursos instrumentais e financeiros extraordinários.

\subsubsection{Aplicação industrial e o critério da utilidade}

Por fim, deve-se ainda analisar se o produto ou processo ao qual se pretende buscar a proteção patentária possui aplicação industrial. Baseando-se em uma interpretação literal da lei, pode-se entender que uma invenção terá aplicação industrial quando puder ser fabricada em série ou utilizada em qualquer classe de indústria.

A aplicação industrial deve envolver alguma forma de interferência humana transformadora que implique em mudança capaz de superar alguma dificuldade prática que não seria possível de forma espontânea no estado natural do objeto ao qual a invenção se aplique. Deve assim a invenção ser entendida não apenas como uma maneira de aplicação industrial e comercial independente, na medida em que deve estar vinculada a uma proposição de solução de um problema prático, de forma pormenorizada e específica, sob pena de não se caracterizar como patenteável.

Esse requisito considera invenção somente aquilo que puder ser produzido pela indústria. Utiliza-se o exemplo da falta de patenteabilidade da máquina de moto-contínuo 
ou movimento perpétuo, que reutilizariam indefinidamente a energia gerada por seu próprio movimento, por se tratar de um equipamento impossível de ser construído ${ }^{111}$.

Em outras palavras, a mera atuação humana e a manipulação de conceitos, produtos e processos naturais, de forma coordenada, não deve ser suficiente para conferir a proteção patentária, devendo ser demonstrada a sua importância, a sua forma de atuação, e, principalmente, como tal produto ou processo é capaz de gerar um resultado prático relevante que atenda a uma necessidade ou problema técnico.

No caso dos resultados originados de produtos biotecnológicos e/ou dos produtos biotecnológicos propriamente ditos, deve ser assegurado que a repetição constante dos resultados previstos e divulgados na reivindicação patentária sejam replicáveis, seja no aspecto estrutural, seja no aspecto funcional.

Esta questão está intimamente relacionada ao teor do artigo 24 da LPI, que exige suficiência descritiva no relatório que integra a reivindicação da patente pleiteada. A invenção que tenha por objetivo uma solução prática, muito embora não determine de forma expressa a demonstração de sua utilidade, é foco de discussão pela doutrina brasileira.

No contexto desta análise, importante identificar e distinguir tal critério do requisito da "utilidade", bastante evidenciado no norte-americano, especialmente em invenções biotecnológicas constituídas por genes/sequências de DNA como material de base de tal criação, haja vista o risco que o sentido e alcance a ser atribuído a uma patente genética poderia abranger objetos ou processos ainda desconhecidos.

Entende SILVEIRA que o mero preenchimento dos requisitos do artigo $8^{\circ}$ da LPI novidade, atividade inventiva e aplicação industrial - é insuficiente, pois, a partir de uma interpretação literal de tal dispositivo, a invenção não precisaria apresentar um resultado prático útil ou um melhoramento técnico novo, originados da intervenção humana. Isso permitiria que uma invenção completamente inútil, porém nova, produzível

111 ROGERS, David. Requirement of industrial application, exclusion of scientific theories from patentability, perpetual motion machines. Journal of Intellectual Property Law \& Practice, Vol. 2, 2a. ed., p. 62. 
industrialmente e resultada de atividade intelectual, pudesse ser patenteável, o que seria um contrassenso na opinião do autor.

Seguindo esta linha de argumentação, a utilidade da invenção deveria ser definida como "a propriedade ou aptidão para servir ao seu fim e corresponder à exigência ou necessidade a cuja satisfação visa o inventor" ${ }^{\prime 12}$, o que coincide com o conceito de utilidade utilizado na economia.

Destarte, embora as consequências secundárias resultantes do uso da invenção possam se mostrar desvantajosas ou até prejudiciais, sendo útil, deve considerada uma invenção. A lei não permite o seu registro caso tenha fins imorais ou ilícitos, mas não deixa de ser uma invenção.

Não basta que o sistema de patentes incentive novas invenções e investimento. Como já tivemos a oportunidade de discutir, é preciso que, a partir da efetiva exploração destas, a humanidade obtenha algum tipo de vantagem, sem a qual "o custo social do empreendimento da concessão de patentes teria sido totalmente inútil" ${ }^{\prime 13}$.

Mesmo o TRIPS, em seu artigo 27, nota 5, admite que os termos "passo inventivo" e "passível de aplicação industrial" sejam lidos como sinônimos de "não óbvio" e "útil" (useful), justamente os termos constantes na legislação norte-americana, que exige declinação de uma aplicação útil à invenção que se pretende patentear. O direito patentário americano prevê expressamente a utilidade como pressuposto de patenteabilidade, conforme o título 35, seção 101 do United States Code (USC), in verbis:

\footnotetext{
"Whoever invents or discovers any new and useful process, machine, manufacture, or composition of matter, or any new and useful improvement thereof may obtain a patent therefor, subject to the conditions and requirements of this title."
}

Neste mesmo sentido, as Guidelines for Examination of Applications for Compliance with the Utility Requirement $[R-11.2013]^{114}$ publicadas pelo Escritório de

\footnotetext{
${ }^{112}$ CERQUEIRA, op. cit., p. 214

113 SILVEIRA, Newton. Propriedade Intelectual. São Paulo: Ed. Manole, 2011, p. 3.

${ }^{114}$ Disponível em: http://www.uspto.gov/web/offices/pac/mpep/s2107.html. Acesso em: 24/11/2014.
} 
Patentes Americano (USPTO) instruem seus examinadores, ao avaliar o critério da utilidade, que identifiquem na reivindicação da patente uma utilidade substancial e específica, ou ao menos a existência de informações suficientes acerca da invenção, que possibilite a imediata identificação de sua utilidade àqueles familiares com o campo tecnológico em questão (critério este denominado well-established utility). Segundo essas diretrizes, em sua revisão editada em 2001, a utilidade deveria ser aferida sob 3 aspectos principais: a utilidade deve ser substancial, específica e crível ${ }^{115}$.

A doutrina americana, aqui representada por ERSTLING, SALMELA e WOO, ao tratar do tema, esclarece a importância da explicitação da utilidade da patente depositada, pela identificação de uso prático no "mundo real", senão vejamos:

\begin{abstract}
"Specific utility must be specific to the subject matter of the claimed invention and not merely generally applicable to the "broad class of the invention." ${ }^{116}$ For example, a statement that an invention is useful to diagnose disease without disclosing a particular disease or condition would lack specific utility, whereas one that discloses a biological activity and "reasonably correlates that activity to a disease condition" would establish sufficient specific utility ${ }^{117}$.
\end{abstract}

Substantial utility can be equated to showing a "real world" use ${ }^{118}$. To establish substantial utility, an applicant must show that an invention is useful as disclosed in its current form, rather than at some time in the future pending additional research"119. "Utilities that require or constitute carrying out further research to identify or reasonably confirm a 'real world' context of use are not substantial utilities." ${ }^{200}$ The MPEP is careful to qualify, however, that "in its

\footnotetext{
115 "In contrast to the relative ease of overcoming the non-obviousness requirements for human gene claims, the PTO is stricter with the requirement that the gene be "useful". In January 2001, the PTO issued the "Utility Examination Guidelines", under which its examiners will test the utility requirements of U.S. patent law. The PTO has indicated that it will apply a three-way test in its examination for utility. To be acceptable, a utility has to be "credible," "specific," and "substantial"." (GOLDSTEIN, Jorge A.; GOLOD, Elina. Human gene patents. Academic Medicine, vol. 77, n 12, Dezembro/2002, p. 1318).

${ }^{116}$ [Nota do original] MPEP, supra note 5, $\S 2107.01$ (I)(A). Many of the examples of specific vs. general utility provided in the MPEP are related to pharmacological and biotech inventions. "[I]ndicating that a compound may be useful in treating unspecified disorders, or that the compound has 'useful biological' properties, would not be sufficient to define a specific utility for the compound."

${ }_{117}^{1}$ [Nota do original] Id. "Assertions that fall in the former category are insufficient to define a specific utility for the invention, especially if the assertion takes the form of a general statement that makes it clear that a 'useful' invention may arise from what has been disclosed by the applicant."

118 [Nota do original] MPEP, supra note 5, § 2107.01(I)(B).

119 [Nota do original] Id. (citing In re Fisher, 421 F.3d at 1371).

${ }^{120}$ [Nota do original] MPEP, supra note 5, § 2107.01(I)(B) ("For example, both a therapeutic method of treating a known or newly discovered disease and an assay method for identifying compounds that themselves have a 'substantial utility' define a 'real world' context of use. An assay that measures the
} 
current form" is not intended to mean that a claimed invention must be "currently available," but rather that any reasonable use that is identified by the applicant and can be seen to provide a public benefit is sufficient to establish substantial utility ${ }^{121,}, 122$.

A jurisprudência americana também é clara neste ponto. Há antecedentes jurisprudenciais esclarecendo que as invenções devem possuir uma aplicação, uma utilidade em relação objetivo pretendido, e, especificamente com relação a produtos químicos e outras invenções que possam ter uma ampla gama de possíveis usos, dentre os quais se inserem os genes humanos "puros", as decisões mais recentes estabelecem a necessidade de atribuir uma utilidade prática ao invento ${ }^{123}$, por meio da qual a descrição da reivindicação patentária deve explicitar os benefícios substanciais diretamente originados da invenção.

Tanto é assim que as concessões de patentes antigamente outorgadas nos EUA relativas a ESTs e SNPs não mais são admitidas ${ }^{124}$, fato este que evidencia a importância da suficiência do relatório descritivo que integra as reivindicações de patentes como forma de demonstração de observância ao critério da utilidade, notadamente quando relacionadas a invenções que tenham por objeto genes humanos.

Segundo BOSTYN, o relatório descritivo de uma reivindicação de patente carecedor de divulgação de ao menos uma função específica da sequência de DNA que se pretende proteger deve ser entendida como uma insuperável dificuldade na concessão de

presence of a material which has a stated correlation to a predisposition to the onset of a particular disease condition would also define a 'real world' context of use in identifying potential candidates for preventive measures or further monitoring. On the other hand, the following are examples of situations that require or constitute carrying out further research to identify or reasonably confirm a 'real world' context of use and, therefore, do not define 'substantial utilities': (A) Basic research such as studying the properties of the claimed product itself or the mechanisms in which the material is involved; (B) A method of treating an unspecified disease or condition; (C) A method of assaying for or identifying a material that itself has no specific and/or substantial utility; (D) A method of making a material that itself has no specific, substantial, and credible utility; and (E) A claim to an intermediate product for use in making a final product that has no specific, substantial and credible utility.").

${ }^{121}$ [Nota do original] Id.

${ }^{122}$ ERSTLING, Jay A.; SALMELA, Amy M.; WOO, Justin N. Usefulness varies by country: The utility requirement of patent law in the United States, Europe and Canada. Cybaris ${ }^{\circledR}$, an Intellectual Property Law Review, 2012. Disponível em: http:/web.wmitchell.edu/cybaris/wp-content/uploads/2012/06/erstlingsalmela-woo.pdf. Acesso em 4 out. 2014, pp. 6-7.

${ }^{123}$ Cf. Brenner v. Manson, 383 U.S. 519, 86 S. Ct. 1033, 16 L. Ed. 2d 69, 148 U.S.P.Q. (BNA) 689 (1966); In re Ziegler, 992 F.2d 1197, 26 U.S.P.Q.2d (BNA) 1600 (Fed. Cir. 1993).

${ }^{124}$ Os ESTs e os SNPs não podem ser consideradas invenções per se, dependendo de uma aplicação prática substancial para que passem a ser entendidas como invenções patenteáveis segundo a atual orientação norteamericana. Para maiores informações a respeito dos ESTs e SNPs, vide Capítulo 2.2.3. 
patente, porquanto ausente a solução técnica que a invenção pretende dar a um problema técnico $^{125}$.

$\mathrm{Na}$ esteira do quanto acima mencionado, o requisito da utilidade para o direito americano demanda a divulgação de ao menos uma forma pela qual o gene pode ser usado ou aplicado, senão vejamos:

\begin{abstract}
"In its final guidelines on the utility requirement for patentability, the PTO requires that the utility be 'specific, substantial, and credible'. To satisfy this requirement, the inventor must disclose at least one way in which the purified gene, isolated from its natural state, may be used or applied, for example, for diagnostic or predictive genetic testing. However, if the applicant does not explicitly identify a specific utility for the isolated gene sequence, the guidelines permit the utility requirement to be satisfied if the examiner believes that an individual with ordinary skill in the art would recognize that the gene or sequence has a readily apparent 'well-established utility.",126
\end{abstract}

Para GOLDSTEIN e GOLOD, muito embora as diretrizes do USPTO adotem uma interpretação mais ampla no que diz respeito ao requisito da atividade inventiva (nãoobviedade), o mesmo não ocorre quanto à utilidade dos genes, segundo a qual o modo de obtenção da invenção e a sua aplicação prática útil devem ser explicitadas de modo inequívoco no relatório descritivo da reivindicação patentária (enabling disclosure) ${ }^{127}$. Tal entendimento reveste-se de grande relevância no âmbito das tecnologias emergentes, em especial aquelas relacionadas às patentes atreladas à engenharia genética, especialmente em razão da recorrente discussão acerca de seu caráter informacional, a partir do qual diversos possíveis usos podem se originar, e que no mais das vezes não são imediatamente

\footnotetext{
${ }^{125}$ Cf. Bostyn "Another criterion which could appear to be problematic to overcome is the enabling disclosure requirement, especially when no specific function of the partial DNA sequence has been disclosed. In such an event, it becomes difficult to produce the solution to the problem, which is supposed to be provided by the invention", (BOSTYN, S. J. R. One Patent a Day Keeps the Doctor Away? European Journal of Health Law, vol 7, nº 3 Set. 2000, p. 237).

${ }^{126}$ ACOG - American College of Obstetricians and Gynecologists. Patents, Medicine, and the Interests of Patients. ACOG Committee Opinion, vol. 100, n 277. 5 Nov. 2002, p. 1054.

127 "In contrast to the relative ease of overcoming the non-obviousness requirements for human gene claims, the PTO is stricter with the requirement that the gene be 'useful'. In January 2001, the PTO issued the 'Utility Examination Guidelines', under which its examiners will test the utility requirements of U.S. patent law. The PTO has indicated that it will apply a three-way test in its examination for utility. To be acceptable, a utility has to be 'credible,' 'specific,' and 'substantial"' (GOLDSTEIN, Jorge A.; GOLOD, Elina. Human gene patents. Academic Medicine, vol. 77, n 12, Dezembro/2002, p. 1318).
} 
aparentes. Como resultado, o critério fundamental de patenteabilidade tem passado a se basear na "utilidade" da invenção ${ }^{128}$.

Isso se deve ao fato de que o conteúdo informacional que os genes codificam podem originar uma extensa variedade de possíveis usos/aplicações, sendo portanto mais difícil a caracterização da extensão que deve ser conferida à proteção patentária. A este respeito, JACKSON esclarece o seguinte:

"If the only utility of a gene sequence was as a single molecule used for one or two things, like a new drug or a paint additive, there would be little difficulty. However, because these molecules also encode information - a portion of the programming that makes life possible - they have a range of potential uses that continues to expand as we learn more and more about biotechnology and information. This "hybrid" nature - that a gene sequence is both technology and information - can make it difficult to judge the scope of a sequence patent and, as a result, make its innovation difficult to predict." 129

Por este motivo, o conceito da utilidade mostra-se de grande relevância para invenções na área química e genômica; a proteção das informações carreadas pelos genes por si só é demasiadamente extensa e, portanto, não se mostra suficiente para se determinar uma exclusão de terceiros na sua utilização, sob pena de se limitar o desenvolvimento técnico-científico no setor. Neste diapasão, HOLLON assevera que:

"Utility is a concept mostly important for chemical and genomics patents, for which inventors may not know the function of a chemical or a gene at the time of filing. The revised utility standard rejects EST patent claiming broad rights to associated genes and proteins on two grounds: A DNA fragment is not useful as a probe for a gene without specifying what is being probed for; and a DNA fragment cannot be used for protein isolation without stating what the patent office calls the protein's "real world" use. The new written description standard will apply to all pending applications - also rejects EST patents: Sequences of

\footnotetext{
${ }^{128}$ CORIAT, Benjamin. O Novo Regime Global de Propriedade Intelectual e Sua Dimensão Imperialista: Implicações paras Relações Norte-Sul. Traduzido e Publicado pelo BNDES no livro "Desafios para o Crescimento" de 2002.

${ }^{129}$ JACKSON, op. cit., p. 6.
} 
cDNA fragments are insufficient to describe the gene they are associated with, and therefore are not sufficient to claim rights to them"130

Ainda, KLUGE sugere que o critério da utilidade seria o mais importante na determinação da patenteabilidade dos genes. Ao analisar as diretrizes das avaliações feitas pelo USPTO e EPO acerca da matéria, identificou KLUGE que o conteúdo genético e as potenciais aplicações a serem conferidas aos genes é que figuram como foco central na corrida pelos desenvolvimentos biotecnológicos:

"On the one hand, these countries [EUA, Canadá, Austrália, países africanos e asiáticos] grant patents on human genes; on the other hand, in a rather intuitive sense, neither human genes nor gene fragments are the results of human manufacture or intervention. However, the patent agencies of the relevant countries - and most particularly the US Patent Office and the European Patent Office Technical Board of Appeal - reject this contention. Specifically, they maintain that the particular chemical units that are the individual genes are not obvious but are identifiable only after very sophisticated biochemical and microbiological research; that individual genes never occur on their own but are obtainable only as the products of deliberate human activity which, in practical terms, produces something that did not exist before; and finally, that anyone who wants to patent a gene must identify the protein that is coded for by that gene. On the basis of this reasoning, the agencies consider themselves justified in granting gene patents. They consider the third condition especially important because even though thousands of genes have been identified, in most cases it is still unknown what proteins or biological processes theses genes code for. This is where the current race for genetic gold is concentrated",131

Sem a necessária declinação das funções/aplicações a que se destinam, não deve ser possível a proteção patentária, devendo, portanto, ser declinada ao menos uma finalidade que satisfaça os critérios acima mencionados ${ }^{132}$, e esta real finalidade deve ser divulgada no ato do depósito do pedido da patente.

\footnotetext{
${ }^{130}$ HOLLON, Tom. Gene patent revisions to remove some controversies. Nature Medicine, vol. 6, no. 4, Abril/2000, p. 362-363.

${ }^{131}$ KLUGE, op. cit., p. 120-121

${ }^{132}$ E, como se verá oportunamente, a extensão da proteção patentária deve se limitar a esta utilidade descrita no relatório descritivo, conforme será discutido no Capítulo 4.
} 
Voltando-se ao sistema de proteção patentária brasileiro, e à luz de todo o contexto acima apresentado, importante que se busque uma interpretação do critério da aplicação industrial (previsto no artigo $8^{\circ}$ da LPI) de forma sistemática, a partir da qual se pode extrair que, além do modelo de utilidade e da invenção serem suscetíveis de aplicação industrial quando possam ser usados ou produzidos em qualquer tipo de indústria, eles devem ser úteis à sociedade (a indústria ou o usuário).

Esse entendimento está explicitado no artigo $9^{\circ}$ da LPI, que se refere aos modelos de utilidade, porém omisso no artigo $8^{\circ}$, que trata das invenções. E assim, com fundamento na doutrina de SILVEIRA, a noção de que a utilidade está implícita em "aplicação industrial" e no próprio conceito de invenção (que a lei não define) - pelo menos quanto aos produtos, deixando-se de lado os processos ${ }^{133}$ - permite e justifica a admissão de tal preocupação no âmbito de proteção das patentes biotecnológicas.

SALOMÃO FILHO também menciona o problema da utilidade na concessão dos privilégios patentários. Ele enxerga a necessidade de descrição de informações indispensáveis ao uso da tecnologia a ser patenteada, e seu respectivo depósito no INPI, como contraprestação do direito exclusivo de uso e fabricação/prestação de serviço por parte do detentor.

Como a informação prestada é, na sua opinião, longe de ser suficiente, "essa dissociação entre prestação e uso da informação cria grandes assimetrias" ${ }^{134}$. Um exemplo de assimetria é aquele decorrente diretamente do monopólio de utilização assegurado legalmente, dizendo respeito à dificuldade de se avaliar a real utilidade do produto:

\footnotetext{
“Aqui, o problema da seleção adversa assume contornos específicos. A atração que causa a invenção será sempre sobre consumidores que tenham um alto grau
}

\footnotetext{
${ }^{133} \mathrm{O}$ mesmo não se aplica aos desenhos industriais (art. 95), que podem ser registrados mesmo quando "inúteis" (ex: flores de plástico), por ocasião de sua função estética. Newton Silveira afirma que a aparente incoerência com o art. 98 da LPI, que impede o registro quando o desenho industrial tiver caráter puramente artístico, explica-se pela interpretação de Tullio Ascarelli, que vê o desenho industrial sob duplo aspecto (SILVEIRA, Newton. A utilidade das invenções, a exclusividade do registro e o dry-martini. Migalhas, 18/01/2011).

${ }^{134}$ SALOMÃO FILHO, Calixto. Direito concorrencial - as estruturas. São Paulo: Malheiros, 2007, p. 162.
} 
de necessidade ou de carência de um certo tipo de solução para o seu problema, ainda que não saibam se aquela solução específica é a mais adequada"135

As condições essenciais para a invenção industrial são, segundo CERQUEIRA, a própria existência de invenção, a realidade desta (a capacidade de conduzir a um resultado possível de ser sempre repetido e obtido, desde que empregados os meios indicados pelo inventor), e a sua utilidade.

A utilidade da invenção é por ele definida como "a propriedade ou aptidão para servir ao seu fim e corresponder à exigência ou necessidade a cuja satisfação visa o inventor" ${ }^{\text {"136 }}$, o que coincide com o conceito de utilidade utilizado na economia. A invenção sem utilidade não poderia ser considerada invenção no sentido técnico-jurídico da palavra, por distinguir as invenções das criações artísticas e das descobertas científicas. Em suma, sustenta que o objeto que não corresponder a nenhuma utilidade não deve se prestar a nenhuma exploração ${ }^{137}$.

Este aspecto tem se mostrado de extrema relevância para a tutela patentária dos genes, sendo que há inúmeros processos biológicos possíveis a eles relacionados que ainda são desconhecidos.

Como aventado anteriormente, sequências de DNA naturalmente ocorrentes podem ser entendidas como matérias-primas das invenções biotecnológicas, e a proteção patentária deve ser concedida apenas àquelas que usam tal matéria prima para criar algo novo, além daquilo já apresentado na natureza. E como se pode inferir do quanto vem sendo aqui apresentado - ainda que em caráter superficial - a concessão de patentes a materiais genéticos humanos, inclusive genes humanos com funções desconhecidas, poderá desvirtuar o sistema de patentes.

Caso tais patentes restrinjam tecnologias fundamentais ou de base, a sociedade corre o risco de não se beneficiar do sistema de patentes, pois elas poderão desestimular as invenções subsequentes. Essas restrições quanto à aplicação dos objetos das patentes devem levar em consideração que os inventores podem se utilizar das leis da natureza ou

\footnotetext{
135 SALOMÃO FILHO, op. cit., 163.

${ }^{136}$ CERQUEIRA, op. cit., 241.

${ }^{137}$ Idem.
} 
fenômenos naturais, porém, a proteção patentária se estende somente àquelas aplicações particulares para as quais suas invenções foram concebidas.

Assim, para que seja possível a proteção da sequência de DNA pretendida, o requerente da patente deverá indicar qual é a função biológica que ela pode desempenhar (e.g. proteína que referida sequência pode sintetizar). Ora, se a lógica do sistema patentário busca premiar os resultados práticos, seria coerente, ao menos à primeira vista, atribuir a exclusividade apenas a estes últimos. Não há porque a mera descoberta, quando desacompanhada de um aporte prático originado do intelecto humano capaz de ser caracterizado como uma invenção, justifique a exclusividade de exploração.

\subsubsection{Doutrina do produto da natureza}

Os elementos ensejadores da patenteabilidade estão todos conceitualmente interrelacionados. Em se tratando especificamente de proteção patentária no âmbito da biotecnologia, eles evidenciam, essencialmente, o fato de que não devem ser reconhecidas patentes em produtos e processos que possam ser verificados em seu estado natural, de forma espontânea.

Tal situação remete a uma das principais discussões jurídicas relativas ao patenteamento de materiais genéticos: a distinção entre invenções e descobertas, sobre a qual se funda a doutrina do produto da natureza. Os conceitos "invenção" e "descoberta" são claramente distintos, sendo esta última excluída do direito de propriedade intelectual na maioria das jurisdições.

A invenção, de modo geral, consiste na criação de algo até então inexistente, consubstanciando-se em uma criação intelectual que transforma a natureza para uma aplicação prática. Tal transformação não deve ser meramente intuitiva, decorrente de uma simples evolução do atual estado da técnica. 
A descoberta, por sua vez, implica na revelação de algo já existente na natureza, pela sua obviedade ou sua possibilidade lógica de existir ${ }^{138}$. E, portanto, não é decorrente do intelecto humano. Neste sentido, CERQUEIRA ensina que:

\begin{abstract}
“(...) A invenção, como dissemos, apresenta-se como a solução de um problema técnico, que visa à satisfação de fins determinados, de necessidades de ordem prática; a descoberta, ao contrário, não visa a fins práticos preestabelecidos e apenas aumenta a soma dos conhecimentos do homem sobre o mundo físico. $\mathrm{Na}$ invenção predomina a aplicação das forças da Natureza, ao passo que as descobertas resultam da aplicação das faculdades intelectuais do homem na investigação dos fenômenos e das leis naturais. Pode-se ainda dizer que, na descoberta, não é o espírito inventivo que atua, mas o espírito especulativo e as faculdades de observação, de modo que, com a descoberta, ficamos no campo da ciência e do intelecto especulativo, ao passo que, com a invenção penetramos no domínio da realização e do intelecto prático "139
\end{abstract}

Apenas a partir do desenvolvimento de uma aplicação prática, com um resultado técnico efetivo, passa a se tornar passível de forma legítima de concessão do direito ${ }^{140}$.

As descobertas científicas se caracterizam pelo mero reconhecimento de fenômenos naturais, propriedades ou leis do universo material até então desconhecidos, não aportando qualquer conteúdo técnico. A descoberta de um produto encontrado espontaneamente na natureza não pode ser considerada uma invenção patenteável, ainda que não seja previamente conhecida. Por isso, afirma CERQUEIRA que as descobertas, muito embora representem na maioria das vezes o ponto de partida de uma invenção, não podem elas por si só ser passíveis de proteção.

Entretanto, processos ou produtos originados da intervenção humana que utilizem as leis da natureza, fenômenos naturais ou ideias abstratas poderão ser considerados invenções, ainda que tais elementos individualmente considerados não o sejam. $\mathrm{O}$ descobridor de uma lei natural ou propriedades naturais de um determinado objeto está meramente estudando os fenômenos da natureza (o que não é passível de privilégio),

\footnotetext{
${ }^{138}$ FERNANDES, Marcia Santana, Bioética, Medicina e Direito de Propriedade Intelectual - Relação entre patentes e células-tronco humanas. São Paulo: Saraiva, 2012, p. 98.

${ }^{139}$ CERQUEIRA, op. cit., p. 222.

${ }^{140}$ CERQUEIRA, op. cit., p. 224.
} 
porém, se há coordenação e utilização de tais "instrumentos" de forma a transformar a natureza, atribuindo-se soluções técnicas, pode-se estar diante de uma invenção.

A este respeito, FELDMAN esclarece que a simples identificação de um biomarcador pode ser facilmente considerada como simples descoberta, pela identificação de um fenômeno da natureza:

\begin{abstract}
"Discovering the fact that $A$ occurs with $B$ is no different from discovering a property of a natural substance or discovering how a biological process unfolds, neither of which would be patentable. Thus, when the invention constitutes no more than the straightforward measurement of a single biomarker, one could easily argue that the invention merely recognizes a natural phenomenon"141.
\end{abstract}

Esta característica é importante por evidenciar o critério da utilidade, acima discutido, uma vez que a aplicação útil apresentada poderá ser justamente o diferenciador daquilo que é uma simples "descoberta", passando a qualificar-se como invenção. A este respeito, FELDMAN avança em seu estudo demonstrando, por analogia, que uma invenção que seja produto do intelecto e intervenção humana na natureza pode se caracterizar como invenção patenteável, muito embora isso não afete a versão da qual tal produto se originou ${ }^{142}$.

Nestes casos, deve-se identificar se os demais passos inventivos do objeto ou processo a ser patenteado correspondem a mais do que uma simples atividade rotineira e conhecida, já utilizada pela comunidade científica. Assim, quando não houver mera constatação do que ocorre espontaneamente na natureza, mas sim uma intervenção do homem de forma a modificar ou criar propriedades ou características de matéria biotecnológica (ou, em última análise, descrever um resultado prático e útil), poder-se-ia falar em invenção.

Vê-se, assim, que um dos principais problemas envolvendo patentes na pesquisa genética é realmente o estabelecimento de um limite entre invenção e descoberta. Entretanto, não apenas em vista dos quanto acima explicitado que se torna possível o

\footnotetext{
${ }^{141}$ FELDMAN, op. cit., p. 1392

142 "Birds can fly, but if an inventor were able to construct an artificial bird capable of flight, that artificial bird would represent an extraordinary and patentable invention, although the patent certainly would not cover nature's own avian version." (FELDMAN, op. cit., p. 1395).
} 
estabelecimento de regra objetiva capaz de diferenciar tais conceitos para fins de realização de teste de patenteabilidade de um objeto biotecnológico.

Os altos investimentos e tempo dispendidos na pesquisa genética - reitere-se - são fatores que não podem ser ignorados também na relativização do conceito de "invenção". Como bem pontua KLUGE, o critério econômico também possui relevância, pois é extremamente custoso fazer com que os genes fiquem em condições de utilização para servir de base às pesquisas e desenvolvimentos, e mais custoso é transformar esses genes em algo que possui uma finalidade útil e prática ao ser humano ${ }^{143}$.

A este respeito, pertinente entendimento de BOSTYN, que acredita ser razoável que se reconheça e permita o patenteamento de produtos da natureza que apresentem pequenas modificações, as quais considera suficientes para diferenciar totalmente o produto natural do produto inventivo:

"It is sufficiently to make a minor modification to the product found in nature in order to avoid non-patentability? Unfortunately, scholars differ in opinion on this subject. According to some, it is not sufficient to purify a substance from nature in order to obtain a patentable invention. This is because this substance will have the same effect and function as the naturally occurring, unpurified substance. I do not follow this line of reasoning. Such a point of view is rather one-sided. It overlooks the problems which the skilled person can encounter in isolating the product, the trials and errors required, the thorough research pursued in order to isolate and analyse the structure and function of the product in question. These activities could amount to an inventive step, and connected with the novelty of the substance, this could lead to patent protection. One of the problems to overcome is to isolate and purify the product in such a way that the function which is present in the naturally occurring substance is also present in the isolated version, and this is not always evident. The other point of view, as opposed to the one I just mentioned and do not agree with, is that it is sufficient to isolate and purify a substance from nature in order to obtain patent protection, because it will require considerable effort, time and research in order to achieve that goal." "144

\footnotetext{
143 "There is the economic argument. The genes for which patents are being sought do not fall like manna from heaven: isolated and purified, as it were, in a ready-to-use state. It costs money to identify and purify them. Even more money is necessary to turn these genes into probes, medications, etc." (KLUGE, op. cit., p. 125).

${ }^{144}$ BOSTYN, 2000, op. cit, p. 232-233.
} 
Especificamente no caso de genes, já tivemos a oportunidade de descrever as várias formas de intervenção humana capazes de modificá-los e torná-los aptos a uma aplicação útil, prática. A este respeito, HOLMAN entende que a separação e purificação dos genes de seu ambiente natural ou a sua síntese em laboratório são meios pelos quais o homem é capaz de extrair de uma base natural um produto potencialmente patenteável:

\begin{abstract}
"Whereas naturally-occurring genes as they exist in the body are considered unpatentable 'products of nature', various forms of human intervention, such as purifying a genetic sequence from its native environment, converting an $m R N A$ to its corresponding $c D N A$, or chemically synthesizing a gene, are considered sufficient to confer patentability upon isolated or recombinant polynucleotides. (...) The principle that purification of a naturally-occurring biological material from its native environment can render the purified product patentable has a long history. For example, in 1873 Louis Pasteur received a patent that claimed 'yeast, free from organic germs of disease, as an article of manufacture" ${ }^{\text {"145 }}$
\end{abstract}

Corroborando tal entendimento, BECKER esclarece que - a partir de uma leitura mais detida e contextualizada - a descoberta tem lugar apenas quando determinado fenômeno ou produto da natureza é notado, porém, o seu "descobridor" permanece como um mero expectador, deixando de intervir ou de qualquer maneira transformá-lo (e para ilustrar tal entendimento, menciona a identificação de uma nova estrela, planta ou inseto na mata virgem). Trata-se de uma situação completamente diferente daquela em que o observador não apenas identifica tal fenômeno, produto ou processo natural, mas também estabelece uma forma de torná-lo reproduzível de modo técnico e comercial para uma finalidade útil e prática, mediante sua extração e isolamento de seu meio original ${ }^{146}$.

As expressões de informação que podem ser extraídas dos genes são essencialmente uma obra da natureza, e sob esta ótica, não estariam amparadas pela

\footnotetext{
${ }^{145}$ HOLMAN, Christopher M. Patent border wars: defining the boundary between scientific discoveries and patentable inventions. Trends in Biotechnology, vol. 25, nº 12, Dezembro de 2007, p. 540.

146 "In political discussions very often the argument is presented that genes cannot be an invention, but only a discovery. Looking more closely at the definition of discovery demonstrates that this is not true. Discovering something means that the existence of an object is noted but the discoverer remains an external spectator. He does not intervene not add to the object. Typical examples of discoveries are a new star, or a new plant or insect in the virgin forest. In contrast, an invention encompasses teaching for repeatable technical measures. The subject matter of the invention is isolated and made available, i.e. separated from its natural surrounding, and a practical use made possible" (BECKER, Konrad. B. Are natural gene sequences patentable? Int. Arch. Occup. Environ. Health, vol. 73, 2000, p. S20).
} 
proteção patentária. $\mathrm{Na}$ medida em que tais genes são encontrados naturalmente, em princípio, não poderiam ser consideradas patenteáveis. Contudo, uma vez purificadas, isoladas ou sintetizadas em laboratório, elas passam a ter características distintivas e utilizações diversas daquelas verificadas naturalmente, cabendo a proteção patentária.

Este parece ser o ponto fulcral na discussão a respeito da equiparação de uma chamada "descoberta" na área biotecnológica a uma invenção, para fins de se assentir pela sua patenteabilidade. Exemplo que ilustra bem esta questão reside em entendimento norteamericano já ultrapassado que permitia o patenteamento irrestrito das ESTs, que são meros marcadores das sequências de DNA que codificam para proteínas, sem que sequer houvesse qualquer preocupação com a declinação da aplicação industrial e utilidade prática de tal sequência. Felizmente tal juízo evoluiu de modo que tais utilidades fossem pormenorizadamente indicadas no relatório descritivo do invento que relacionava ESTs como objetos nas respectivas reivindicações de patentes.

A este respeito, a lição de MARQUES é no sentido de que deve ser levada em consideração uma "noção complexa de descoberta: as descobertas não patenteáveis e as descobertas patenteáveis", distinguindo-se a segunda pelo fato de que se verifica uma intervenção humana dotada de concreta utilidade:

"Haveria, pois, que considerar uma noção complexa de descoberta: as descobertas não patenteáveis e as descobertas patenteáveis. Donde, de um lado, caberia individualizar os princípios, os métodos matemáticos, as teorias científicas, as propriedades e os fenómenos naturais e, do outro, as matérias inorgânicas (v.g., minerais) e as matérias biológicas (v.g., microrganismos, virus, bactérias, genes, etc.). Somente no que toca a este último grupo de coisas é que se faria mister fazê-lo aceder ao domínio do patenteável. Que o mesmo é afirmar que as descobertas de per se, consideradas enquanto tal e desprovidas de uma imediata utilidade industrial, não seriam patenteáveis. Pelo contrário, as descobertas materializadas em objetos (biológicos ou não biológicos), uma vez despidas da roupagem abstractizante e teorizante de que, ab initio, se revestiriam, poderiam aceder a estalão de invenções, contanto que seu objeto fosse, por si só e por influência de uma intervenção humana técnica, um produto susceptivel de aplicação industrial. 
Assim, o poderem as matérias biológicas, meramente isoladas de seu ambiente natural, possuir uma concreta utilidade elou industrialidade constataria a veracidade daquela última proposição: a patenteabilidade das descobertas aplicadas industrialmente (...),"147

Corroborando tal entendimento, o art. 5(3) da Diretiva da União Europeia (UE) direciona em que ocasiões os produtos de pesquisas com genes humanos podem ser patenteados, estabelecendo que o resultado do trabalho científico deverá estar sempre acompanhado de uma descrição original do método que levou à invenção, bem como de explicação pormenorizada da aplicação industrial a qual referido trabalho originou:

\footnotetext{
"Thus, as is stated in the twentieth and twenty-first recitals of the preamble to the Directive, an element of the human body may be part of a product which is patentable, but it may not, in its natural environment, be appropriated. (...) The result of such work can give rise to the grant of a patent only if the application is accompanied by both a description of the original method of sequencing which led to the invention and an explanation of the industrial application to which the work is led, as required by Article 5(3) of the Directive. In the absence of an application in that form, there would be no invention, but rather the discovery of a DNA sequence (...)"148
}

Ante tudo o quanto apresentado neste Capítulo, este se mostra um caminho adequado para se justificar a viabilidade de se conferir a proteção patentária aos genes humanos. Neste caso, contudo, as condições e extensão desta possível patenteabilidade deverão ser consideradas à luz de todos os aspectos anteriormente discutidos, de modo a se assegurar o atingimento dos fundamentos de validade e existência do sistema patentário.

Com base nisso, mostra-se possível o estabelecimento de diretrizes objetivas que irão nortear o teste que irá apontar ou não pela patenteabilidade, bem como pela extensão a ser conferida por tal patente biotecnológica.

\footnotetext{
${ }^{147}$ MARQUES, op. cit., pp. 30-31.

${ }^{148}$ BOSTYN, S. J. R. The prodigal son: the relationship between patent law and health care. Medical Law Review, 11, Primavera/2003, p. 83.
} 


\subsection{Limitações ao exercício do direito patentário}

Como visto, a propriedade não é sobre o objeto da criação, mas sobre os direitos de exploração da criação intelectual. E que a proteção patentária conferida refere-se ao direito do titular da invenção excluir terceiros de explorá-la economicamente.

Esta conceituação é relevante ao se tratar de patentes biotecnológicas, especialmente aquelas originadas a partir da atuação da engenharia genética, pois sua maior contribuição se dá na área da saúde e vida humana, além de lidar - direta ou indiretamente - com aspectos outros que podem obstar seu exercício pleno e regular, e também de limitar a sua utilização excessiva.

O resultado disso é que uma invenção biotecnológica que atenda a todos os requisitos autorizadores de sua proteção pela via patentária alcançada, para que possa ser objeto de exploração econômica, efetivamente, deverá ainda estar sujeito a alguns controles adicionais de ordem legal e regulatória.

Diante desse contexto, importa mencionar que nem todo produto ou processo que observe todos esses requisitos será patenteado, portanto; a lei, por questões políticas sejam elas motivadas por questões de ordem ética, religiosa, econômicas ou outras poderá excluí-los da proteção do sistema patentário.

Em outros casos, haverá uma permissão legitimada pela lei para que terceiros utilizem tal invento sem que isso seja considerada uma ofensa ao direito de proteção patentária outorgado ao seu titular, ou ainda poderão ser utilizados mecanismos que obstem eventuais situações de abuso de direito pelo detentor da patente.

Ainda, em se tratando de patentes biotecnológicas cujas aplicações são voltadas à área das ciências biomédicas e medicina molecular, poderá existir a necessidade de um controle regulatório (no caso do Brasil, por parte da ANVISA), haja vista questões de saúde pública que poderão estar atreladas à comercialização de inovações biotecnológicas que venham a ser consideradas patenteáveis pelo INPI. É sobre esses assuntos que em seguida se passa a discorrer. 


\subsubsection{Produtos e processos não patenteáveis}

Em primeiro lugar, assim como se pode identificar de forma reiterada em outras jurisdições, a LPI estabelece algumas situações em que processos e produtos não podem ser considerados elegíveis como patenteáveis.

Isso se deve ao fato de não se originarem de formas de intervenções humanas novas, dotadas de carga inventiva relevante ou aplicação industrial (critérios estes necessários para se justificar a exclusão de terceiros de sua exploração econômica, como acima já mencionado), ou por serem tutelados por outros sistemas de proteção intelectual (e.g. lei de direitos autorais e de programas de computador).

Tais hipóteses podem ser localizadas no artigo 10 da LPI, a saber: (a) descobertas, teorias científicas e métodos matemáticos; (b) concepções puramente abstratas; (c) esquemas, planos, princípios ou métodos comerciais, contábeis, financeiros, educativos, publicitários, de sorteio e de fiscalização; (d) as obras literárias, arquitetônicas, artísticas e científicas ou qualquer criação estética; (e) programas de computador em si; (f) apresentação de informações; (g) regras de jogo; (h) técnicas e métodos operatórios ou cirúrgicos, bem como métodos terapêuticos ou de diagnóstico, para aplicação no corpo humano ou animal; e (i) o todo ou parte de seres vivos naturais e materiais biológicos encontrados na natureza, ou ainda que dela isolados, inclusive o genoma ou germoplasma de qualquer ser vivo natural e os processos biológicos naturais.

Como já analisado no Capítulo 3, as alíneas "a", "h" e "i” estão diretamente relacionadas ao objeto do presente estudo, estando a avaliação acerca da patenteabilidade dos genes diretamente ligada à aferição de tais aspectos em relação à natureza de composto químico dos genes, a distinção entre “invenção" e “descoberta”, e a aplicação industrial/utilidade dos genes. 


\subsubsection{Intervenção da Anvisa nos processos de patentes biotecnológicas}

É dever da Anvisa, em função do art. $6^{\circ}$ da Lei 9.782/99, “promover a proteção da saúde da população" e, como tal, cabe-lhe avaliar e aprovar ou não a viabilidade técnica da comercialização de medicamentos.

A partir desta afirmação surge uma aparente sobreposição de competências, quando se discute a aprovação de medicamentos passíveis de proteção patentária, em razão de suas especiais características - situação esta que deve ocorrer com certa frequência no campo da biotecnologia.

Como agência reguladora especializada em saúde, a Anvisa deve ser responsável pela regulação do setor e defesa dos usuários, enquanto ao INPI cabe ao analisar os pedidos de registro de forma geral, sem prejuízo dos entendimentos da ANVISA.

Nada obstante, como já visto, as patentes possuem natureza de um direito negativo $^{149}$. Ou seja, a concessão da patente traz a certeza de que o titular pode afastar erga omnes o uso e a exploração por terceiros, mas não garante o direito de uso e exploração pelo próprio titular.

Destarte, o papel da Anvisa seria de uma "segunda chancela" (sendo a primeira o INPI) para a comercialização dos medicamentos originados da patente de segundo uso. Esta função é de grande importância e salutar para saúde pública; entretanto, por outro lado, tal prática pode gerar incongruências e dificuldades nas concessões de patentes biotecnológicas em razão de entendimentos contrapostos que podem surgir entre referidos órgãos da administração pública, como aparenta ser o caso das patentes de $2^{\circ}$ uso, o que será abordado no Capítulo 4.3.2.1, abaixo.

\subsubsection{Legítima utilização de patentes por terceiros}

Além dos casos em que, por acordo de vontade das partes, terceiros podem ser autorizados pelos detentores de patentes a explorá-las economicamente por meio da

$\overline{{ }^{149} \text { BARBOSA, 2010, op. cit., } 1489 .}$ 
outorga de licenças, a LPI prevê certas limitações aos direitos conferidos a titulares de patentes.

De acordo com o disposto em seu artigo 43, detentores de patentes não podem impedir terceiros de: (a) explorar objeto de patente em caráter privado e sem finalidade comercial, desde que não acarrete prejuízo ao interesse econômico do detentor do título; (b) praticar atos com finalidade experimental, relacionados a estudos ou pesquisas científicas e/ou tecnológicas; (c) preparar medicamentos de acordo com prescrição médica para casos individuais; (d) explorar produto fabricado de acordo com patente de processo ou de produto que tiver sido colocado no mercado interno diretamente por titular de patente ou com seu consentimento; (e) no caso de patentes relacionadas à matéria viva, utilizar sem finalidade econômica objeto de patentes como fonte inicial para $o$ desenvolvimento de variação ou propagação para obter outros produtos; (f) ainda no caso de patentes relacionadas à matéria viva, explorar economicamente produto patenteado que haja sido introduzido licitamente no comércio pelo detentor da patente ou por detentor de licença, desde que o produto patenteado não seja utilizado para multiplicação ou propagação comercial da matéria viva em causa; ou (g) praticar atos relacionados à invenção protegida por patente, destinados exclusivamente à obtenção de informações, dados e resultados de testes, visando à obtenção do registro de comercialização, no Brasil ou em outro país, para a exploração e comercialização do produto objeto da patente, após a expiração de seu prazo de vigência.

Há também a definição daquilo que - apesar de cumprir os requisitos de patenteabilidade - não pode ser patenteado de forma alguma. O artigo 18 da LPI lista as tais situações em seus incisos, a saber: (a) o que infringir a moralidade, bons costumes, segurança, ordem e saúde públicas; (b) as substâncias, matérias, misturas, elementos ou produtos de qualquer espécie, bem como a modificação de suas propriedades físicoquímicas e os respectivos processos de obtenção ou modificação, quando resultantes de transformação do núcleo atômico; e (c) o todo ou parte dos seres vivos, exceto os microrganismos transgênicos que atendam aos três requisitos de patenteabilidade novidade, atividade inventiva e aplicação industrial - previstos no artigo $8^{\circ}$ e que não sejam mera descoberta. 
Sem prejuízo da questão de objetos e processos inventivos cuja patenteabilidade é negada por razões de moralidade e ordem pública, que podem de alguma forma afetar a presente análise, importa considerar aqui a limitação contida no inciso III do dispositivo legal supracitado, que não permite o patenteamento do "todo ou parte dos seres vivos".

Como já discutido previamente, a patenteabilidade dos genes não se enquadraria neste contexto em razão de sua natureza, por ser considerado um composto químico, basicamente, que não deve ser confundida com a apropriação e coisificação do ser humano, sendo certo que este não deve ser entendido como um simples conjunto de instruções genéticas que orientam sua formação e funções biológicas ${ }^{150}$.

\subsubsection{Licenciamento Compulsório}

A LPI prevê algumas hipóteses em que uma patente pode ser licenciada compulsoriamente a terceiros, mediante requerimento ao INPI.

A primeira delas refere-se ao exercício abusivo dos direitos decorrentes de patente pelo seu titular. Segundo VIEGAS:

“a 'forma abusiva' mencionada no art. 68 da LPI não se confunde com 'falta de uso', e também não se confunde com 'abuso de poder econômico'. A ausência de uma definição do que seja 'abuso' exige uma análise caso a caso, mas, por exemplo, a prática de preços excessivos, principalmente quando aplicados a produtos de necessidade básica ou de interesse público, tornando-os inacessíveis a populações carentes, pode constituir uma forma de abuso. " 151

Da mesma forma, abuso de poder econômico, comprovado por decisão administrativa do Conselho Administrativo de Defesa Econômica (CADE) ou judicial, também configura situação ensejadora de licenciamento compulsório de patentes. De acordo com o artigo 38, inciso IV, alínea “a”, da Lei no 12.529/2011 (Lei Antitruste), na hipótese de prática de infração concorrencial, quando a gravidade dos fatos ou o interesse

\footnotetext{
${ }^{150}$ Relativamente à conceituação e natureza dos genes, vide Capítulo 2.2.2.

${ }^{151}$ VIEGAS, Juliana. L. B. In: SANTOS, Manoel J. Pereira dos; JABUR, Wilson Pinheiro. Contratos de Propriedade Industrial e Novas Tecnologias - Propriedade Intelectual. Série: GVlaw. São Paulo: Saraiva, 2007, p.132.
} 
público geral assim o exigir, o CADE poderá recomendar ao INPI que seja concedida licença compulsória de patentes de titularidade do infrator.

A falta de exploração da patente no território brasileiro, ou sua comercialização insuficiente (em relação às necessidades do mercado) ${ }^{152}$, da mesma forma, poderá autorizar o Estado a realizar a licença compulsória da patente.

Há ainda os casos de emergência nacional e de interesse público, que poderão dar origem à licença compulsória. Estes são definidos pelo Decreto n ${ }^{0} 3.201 / 1999$ como “os fatos relacionados, dentre outros, à saúde pública, à nutrição, à defesa do meio ambiente, bem como aqueles de primordial importância para o desenvolvimento tecnológico ou socioeconômico do País" "153, enquanto aqueles são caracterizados como "iminente perigo público, ainda que apenas em parte do território nacional ${ }^{, 154}$.

Entretanto, a hipótese de licenciamento compulsório que parece ser mais relevante para o objeto do presente estudo refere-se à questão da dependência de uma patente em relação a outra. Via de regra, esta hipótese deve ser verificada quando a patente

\footnotetext{
${ }^{152}$ De acordo com VIEGAS: “(q)uando a patente não for explorada no território brasileiro, seja por falta de fabricação, seja por fabricação incompleta do produto ou por falta de uso integral do processo patenteado (art. 68, $\$ 1^{\circ}$, I), uma licença compulsória também pode ser pleiteada. (...) Nesta hipótese, a outorga de licença compulsória parece muito dificil, pois a LPI prevê várias exceções, que provêm o titular da patente ameaçada com várias possíveis defesas contra uma licença não desejada, tais como: (i) A LPI admite o nãouso por inviabilidade econômica, hipótese em que a importação do produto será permitida (art. 68 , $\$ 1^{\circ}$, I). $O$ conceito de 'inviabilidade econômica' não está definido na LPI, e poderá ser interpretado de forma flexível, permitindo amplas e diferentes justificativas baseadas em inviabilidade econômica para evitar a licença compulsória. (ii) Também não será concedida licença compulsória com base em falta de uso se o titular da patente justificar o desuso por 'razões legítimas' (art. 69, I, da LPI, que reproduz o disposto no artigo 5-A (4) da CUP). Igualmente, não há definição do que sejam 'razões legítimas', permitindo-se, pois, o recurso a uma ampla gama de justificativas técnicas, mercadológicas, financeiras, tributárias ou de qualquer outra natureza (desde que legítimas), para impedir a licença compulsória. (iii) Se o titular da patente comprovar a realização de sérios e efetivos preparativos para a sua exploração, a licença compulsória também não será concedida (art. 69, II). (iv) Finalmente, a licença compulsória igualmente não será outorgada se o titular da patente justificar a falta de fabricação ou comercialização por obstáculo de ordem legal (art. 69, III)." (VIEGAS, op. cit, p.134)

153 “A licença compulsória, nesta hipótese, só pode ser para uso público não comercial (isto é, o licenciado deve ser órgão ou entidade governamental e a exploração da patente não pode ser feita com propósito comercial, mas deve ser preferivelmente para distribuição gratuita ou a preço de custo), não pode ser exclusiva e fica sujeita a pagamento de royalties, sendo que o INPI poderá designar comissão para arbitrar a remuneração." (SANTOS, Manoel J. Pereira dos; JABUR, Wilson Pinheiro. Contratos de Propriedade Industrial e Novas Tecnologias - Propriedade Intelectual. Série: GVlaw. São Paulo: Saraiva, 2007, p.139) 154 "O art. 71 da LPI explicita que, mesmo em casos de emergência nacional, o licenciamento compulsório deve ser outorgado 'sem prejuízo dos direitos do respectivo titular'. Esta observação leva ao entendimento de que (a) o titular pode certamente continuar a explorar a patente (mesmo porque a licença compulsória é temporária e não exclusiva) e (b) a licença poderá gerar royalties pagáveis ao titular." (SANTOS; JABUR, op. cit., p.138).
} 
dependente representar substancial progresso técnico em relação à anterior, e quando o titular da patente original não realizar acordo com o titular da patente dependente:

“O artigo 31 (1) do TRIPS admite expressamente a licença compulsória em caso de patente dependente, quando a patente dependente representar 'um avanço técnico importante de considerável significado econômico em relação à invenção identificada na primeira patente'. A LPI faz menção a "substancial progresso técnico', sem mencionar a necessidade de esse progresso técnico ter 'considerável significado econômico', omissão que pode ter alguma relevância em casos concretos, e que pode servir de defesa a titular da patente anterior. Igualmente, como já vimos, a LPI também não exige que tenha havido negociações em condições e por lapso temporal razoáveis, antes que se possa outorgar a licença compulsória, preliminares expressamente exigidas pelo TRIPS para toda e qualquer hipótese de licença compulsória. Outra discrepância entre a LPI e o TRIPS, com relação a esta quinta hipótese de licenciamento compulsório por dependência de patentes, refere-se à exigência (no artigo 31 (1), inciso (iii) do TRIPS) de que 'o uso autorizado com relação à primeira patente será não transferível, exceto com a transferência da segunda patente'. Na LPI há uma previsão semelhante, porém não idêntica, que se aplica a todas as hipóteses de licenciamento compulsório. Esta previsão, contida no art. $74, \S 3^{\circ}$, estabelece que, após a concessão da licença compulsória, somente será admitida a sua cessão quando realizada conjuntamente com a cessão, alienação ou arrendamento da parte do empreendimento que a explore. Como a cessão do empreendimento que explora uma patente deve incluir a cessão da mesma patente, parece-nos que a exigência contida no artigo 31 (1) (iii) do TRIPS esteja cumprida pelo disposto no art. $74, \S 3^{\circ}$, da LPI. "155.

O problema das patentes dependentes é latente nessa discussão em virtude do já mencionado conteúdo informacional dos genes, haja vista que esta importante característica tem como consequência imediata uma possível limitação ao acesso a materiais de base para desenvolvimentos biotecnológicos subsequentes. Assim, a depender da extensão a ser conferida às patentes genéticas, tal situação deve originar situação de licença compulsória, sob pena de se inviabilizarem os desenvolvimentos subsequentes aos quais o progresso cientifico e tecnológico estão adstritos ${ }^{156}$.

\footnotetext{
${ }^{155}$ SANTOS, Manoel J. Pereira dos; JABUR, Wilson Pinheiro. Contratos de Propriedade Industrial e Novas Tecnologias - Propriedade Intelectual. Série: GVlaw. São Paulo: Saraiva, 2007, p.136).

${ }^{156}$ Este assunto será detalhado no Capítulo 4.
} 


\section{PATENTEAmEnto de Genes E RESTrição AO ACESSO A INFORMAÇÕES BIOTECNOLÓGICAS}

\subsection{Invenções pioneiras e desenvolvimentos subsequentes}

Muito se questiona a respeito da possibilidade de patenteamento dos genes humanos, em função da amplitude que tal proteção poderia conferir aos seus titulares, uma vez que a apropriação de sequências genéticas cujas funções/aplicações biológicas não sejam à época identificadas poderia constituir entrave para o desenvolvimento científico e tecnológico na genética.

Mais que isso, tal situação poderia potencialmente originar insustentável discrepância econômica entre determinados agentes geradores de "conhecimento", na medida em que o titular da patente genética originária poderia se beneficiar de estudos técnico-científicos posteriormente realizados por terceiros que venham a determinar funções biológicas até então desconhecidas, compartilhando com estes os resultados econômicos de tais possíveis aplicações subsequentes.

Como já discutido no Capítulo 3.1, na ausência de fundos governamentais, as organizações privadas devem possuir incentivos para apoiar a pesquisa e o desenvolvimento em biotecnologia, mediante justificação de seu interesse social. E os financiamentos privados, por sua vez, estão intimamente ligados à existência de patentes que irão proteger tais investimentos e garantir seus respectivos retornos.

Neste sentido, a outorga de direitos patentários a uma determinada tecnologia e a participação de seu detentor em novas invenções a ela relacionadas constituem importantes aspectos a serem considerados na decisão da iniciativa privada em apoiar tais projetos de P\&D.

Ao passo que as patentes podem configurar um bom incentivo ao progresso científico, sua concessão de forma muito ampla pode não ser a melhor forma de se promover o suficiente acesso à informação e à livre concorrência, elementos indispensáveis ao progresso científico, econômico e social. A exclusividade de exploração 
gerada pela proteção patentária pode assim implicar restrição ao acesso às contribuições cumulativas de pesquisas científicas diversas ${ }^{157}$, por obstar tal desenvolvimento. Tal problemática é acentuada no âmbito da engenharia genética, tendo em vista que todos os seus desenvolvimentos - em última análise - partem de um mesmo produto: o gene.

Devem assim os resultados originados da concessão de uma patente ser cautelosamente observados, a fim de que seja permitido o alcance de seus objetivos de modo adequado. Em um primeiro nível, deve ser verificado como se relacionam os inventores pioneiros e aqueles envolvidos em novas criações oriundas - direta ou indiretamente - de tais invenções originais; num segundo nível, como esta relação pode ser benéfica ou prejudicial aos objetivos mediatos do sistema patentário, e como esta composição de interesses se justifica socialmente.

Como as consequências negativas da limitação de informação e de acesso aos bens podem ser mais ou menos socialmente sensíveis - a depender da área do conhecimento a que se relacionar -, a questão da extensão da proteção patentária pode se tornar relevante. É exatamente tal questão que vem se mostrando cada vez mais relevante ao se tratar de biotecnologia.

Uma invenção genética, muito embora envolva um material químico (o DNA) em sua proteção, em verdade, possui como peça central a proteção de suas respectivas

\footnotetext{
${ }^{157}$ A título ilustrativo, importa trazer comentário relativo a entendimento jurisprudencial americano exarado em 1985, tratando da necessidade de suficiência descritiva e circunscrição da proteção àquilo que seja efetivamente inventado, originado de demanda judicial intentada por Thomas Edison em relação a concessão de patente reivindicando proteção para materiais utilizados em filamentos de lâmpadas: "In 1895, Thomas Edison brought a Supreme Court challenge to a very broad patent held by Sawyer and Mann for materials used in light bulb filaments. The patentees had found that carbonized paper worked as an effective lightemitting conductor in light bulbs. Based on this invention, they filed a patent claiming the right to use all carbonized fibrous or textile material as an incandescing conductor. Edison challenged Sawyer and Mann, contending that the claim was too broad: it did not indicate which of the thousands of 'fibrous or textile material[s]' would work as conductors in light bulbs, since most do not. Nor did it describe any method for finding out. In effect Edison argued that all Sawyer and Mann had invented was a carbonized paper conductor for use in a light bulb, not a broad class of materials. Edison pointed to his own painstaking experimentation with a wide variety of materials, arguing that his discovery that a particular part of a variety of bamboo plant performed well as a filament was not made any easier by Sawyer \& Mann's disclosure. The Court agreed, stating that '[i]f the description be so vague and uncertain that no one can tell, except by independent experiments, how to construct the patented device, the patent is void.' The patent would have been upheld, the Court suggested, if it had claimed only what Sawyer and Mann had actually invented (carbonized paper incandescence); it was invalid, however, since it would take a good deal of additional experimentation to determine whether incandescing conductors could be made out of the many materials they claimed." (MERGES, Robert P.; NELSON, Richard R. On the Complex Economics of Patent Scope. Columbia Law Review, 1990, p. 844)
} 
“informações genéticas" que possuem inestimável valor no desenvolvimento de diversas aplicações biotecnológicas ${ }^{158}$. O que ocorre é que, ao invés de se buscar o controle de uma invenção em específico, verifica-se uma tentativa de se controlar o conteúdo informático das sequências de genes por meio das patentes. A consequência desta prática deve ser analisada, pois isso pode ter implicações para inovações atuais e subsequentes.

Como já visto, uma mesma sequência de DNA pode ter um número infinito de aplicações possíveis, que - via de regra - não são conhecidas no momento da reivindicação de patente relacionada a um determinado gene. Esta ampla variedade de potenciais usos apenas poderá se tornar realidade com o desenvolvimento da engenharia genética.

Um dos principais aspectos a ser considerado neste contexto é que parecem inexistir bens ou processos substitutos que possam viabilizar o desenvolvimento técnicocientífico da engenharia genética: muito embora o cDNA - tal qual o DNA isolado de seu ambiente natural e/ou purificado - possua uma estrutura físico-química diversa do gene nativo correspondente, já se viu oportunamente que a informação por ele carreada é essencialmente a mesma. Por esse motivo, os genes podem ser considerados fontes primárias da pesquisa biotecnológica.

Emerge desta questão o problema da possível legitimação de uma indevida apropriação dos genes por particulares, problema este que - com a superação da questão de sua não exclusão da patenteabilidade - reside justamente na amplitude de sua concessão. A concessão de uma patente a um segmento de DNA humano, em um cenário mais amplo, poderá gerar um direito capaz de permitir ao seu titular que limite a ocorrência do fenômeno natural do próprio gene, como ele existe no corpo humano.

Pondera MARQUES que no âmbito de proteção patentária biotecnológica podem existir problemas atinentes:

“(...) ao risco de o sentido e o alcance das reivindicações (ainda que com o auxílio dos desenhos e do material biológico depositado) abranger coisas ou

\footnotetext{
${ }^{158} \mathrm{Na}$ grande maioria dos requerimentos de concessão de patente, as reivindicações são muito amplas no sentido de abarcar também outros poli nucleotídeos naturais ou sintéticos que carreguem a mesma informação extraída do DNA. Este comportamento indica claramente que as informações contidas nos genes são mais importantes do que as sequências físicas dos ácidos nucleicos presentes na fita de DNA individualmente considerada.
} 
processos (biológicos) que ainda não existem, atribuindo-se, irrazoavelmente, ao inventor, um âmbito de proteção mais alargado. Isto, porque no sector da biotecnologia detecta-se maior impredictibilidade de resultados do que em qualquer outro setor. Razão pela qual o problema do âmbito de proteção das patentes reveste uma singular importância." 159

Sendo assim, como seria possível limitar a utilização de um gene, ou mesmo uma versão artificial deste elemento, quando há tanto ainda a ser desenvolvido? Neste contexto, patentes desta natureza seriam capazes de bloquear a ocorrência de pesquisas de base por conferir exclusividade de exploração que imponha uma arbitrária limitação a estudos e pesquisas que daí podem se originar.

\subsection{Desenvolvimentos biotecnológicos na ausência de proteção patentária}

Existem posicionamentos contrários à concessão de tutela patentária aos desenvolvimentos biotecnológicos; tais entendimentos buscam sustentação em distintas linhas argumentativas.

Em primeiro lugar, justifica-se a impossibilidade de proteção aos conhecimentos biológicos, por se tratarem de fonte de inestimável importância que integra o patrimônio comum da humanidade, devendo portanto ser distribuídos e compartilhados com toda a coletividade; e, por isso, não deveria ser objeto de monopólio para usos e benefícios $\operatorname{privados}^{160}$.

Muito embora seja reconhecida a importância do conhecimento tradicional e comum, fato é que tal situação não se mostra economicamente sustentável, em razão das

\footnotetext{
${ }^{159}$ MARQUES, op. cit., p. 43-44.

160 "Biological knowledge is among the most important types of information possessed by any culture, a fact long recognized and emphasized by anthropologists. The inestimable value of biological knowledge leads to the principle that such knowledge is a common heritage to be shared for the benefit of all of humanity, rather than a monopoly for private gain. The public nature of most biological knowledge systems means that their information is noncommoditized, although it may be esoteric and unevenly distributed. Some individuals may possess more biological knowledge than others, but the uneven distribution of knowledge does not vitiate the principle of common heritage. Access to special biological knowledge may be restricted to persons of a given status (e.g., women, kin group members, initiates, shamans). Knowledge may reinforce power and privilege but not be monopolized or commoditized for private benefit. This point was made by Herskovits (1952:390), who disputed Bunzel's (1938) assertion that monopoly like restrictions in nonliterate cultures establish the conditions for class formation." (BRUSH, Stephen B. Indigenous Knowledge of Biological Resources and Intellectual Property Rights: The Role of Anthropology. American Anthropologist, New Series, Vol. 95, No. 3. Sep., 1993, p. 657).
} 
peculiaridades da pesquisa científica biotecnológica, que - como já mencionado - envolve experimentação, elevados custos e prazos de retornos, além dos riscos atrelados às incertezas dos resultados obtidos, seja pelo seu alcance, seja pela sua efetiva possibilidade de usos.

Nada obstante, tal argumento - especialmente no campo da engenharia genética -, deve analisado à luz da discussão relativa ao tema invenção $x$ descoberta $^{161}$, podendo ser considerado válido apenas neste último caso - situações que envolvem meramente elementos biológicos naturais e/ou a identificação de fenômenos naturais.

Ademais, sustenta-se que a proteção patentária seria dispensável em razão da possibilidade de alcançar o desenvolvimento técnico-científico por meio de financiamentos públicos. Tal modelo seria socialmente mais interessante, pois os resultados de tais pesquisas teriam um amplo e irrestrito acesso, situação esta que permitiria a evolução tecnológica em um ambiente mais adequado e eficiente ${ }^{162}$.

O cenário do fomento público às pesquisas acadêmicas em universidades visando à realização de pesquisas fundamentais, de modo que suas descobertas se tornem disponíveis ao público, é - em teoria - bastante interessante. As pesquisas científicas de base que são realizadas em universidades seriam subsidiadas, sendo que a publicação de tais resultados e o reconhecimento acadêmico são entendidos como incentivos suficientes na esfera puramente acadêmica.

E, a partir daí, desenvolvimentos subsequentes de natureza comercial pela inciativa privada poderiam ser buscados; sob este prisma, o setor acadêmico estaria voltado à realização de pesquisas de base, enquanto o setor privado poderia focar nos desenvolvimentos subsequentes com aplicação econômica, ou seja, na produção e

\footnotetext{
${ }_{161}$ Assunto este objeto do Capítulo 3.5.4.

162 "Economic efficiency has emerged as the principal reason in favor of intellectual property rights. In Joan Robinson's memorable analysis, intellectual property rights pose a fundamental paradox: 'the justification of the patent system is that by slowing down the diffusion of technical progress it ensures that there will be more progress to diffuse' (Robinson 1956:87). In creating state-sponsored monopolies, intellectual property rights increase the cost of using new ideas, limit competition, and foster a cumbersome bureaucratic and legal framework that is often inequitable to economically or politically disadvantaged persons." (BRUSH, Stephen B. Indigenous Knowledge of Biological Resources and Intellectual Property Rights: The Role of Anthropology. American Anthropologist, New Series, Vol. 95, No. 3. (Sep., 1993), p. 656).
} 
comercialização dos produtos daí originados - estes, portanto, sujeitos à tutela patentária $^{163}$.

Ocorre que - talvez em virtude da inexistência e/ou má-gestão ${ }^{164}$ de políticas públicas definidas no que diz respeito a dotações do orçamento público em P\&D na biotecnologia, ou mesmo em razão dos elevadíssimos custos e riscos inerentes que somente poderiam ser suportados por agentes dotados de grande poder econômico - tem-se notado, em certas jurisdições, uma relação simbiótica não necessariamente interessante entre meios acadêmicos e a iniciativa privada, esta na condição de entidades financiadoras de projetos visando ao desenvolvimento biotecnológico. Por meio de arranjos contratuais, a iniciativa privada acaba por assumir os direitos de exploração econômica dos resultados auferidos de pesquisas de bases científicas originadas em meio acadêmico. GOLDSTEIN e GOLOD, acerca desta questão, esclarecem que:

\begin{abstract}
"It is generally assumed by commentators that anything a corporation does has some sort of commercial intent, no matter how remote. On the other hand, the activities of most university laboratories are without any commercial intent, and therefore, are not actionable patent infringement. Universities, however, have slowly been blurring the boundaries between commercial and noncommercial activities. For example, a university laboratory that is fully funded by the corporate research grants of a major multinational corporation, and has contractually committed to give the corporation exclusive patent rights, might have a difficult time arguing that the research it is carrying out does not have a ultimate commercial intent."165
\end{abstract}

\footnotetext{
163 "A final point regarding the Coase Theorem, and one with application to issues of patentability as well, has to do with the reward system in science and the academy generally. Precisely because a fruit of truly basic research has by definition no immediate or foreseeable commercial applications, the incentives for basic research have to come elsewhere than from the market for commercial goods and services. They come from academic salaries and from the prestige that accrues to successful scientists and other academics, and the salaries are in turn a function to a considerable extent of that prestige. Academics compete with one another to maximize their reputation, and success in that competition depends on the widespread adoption of their creative ideas, "copies" of which-uses of which by other academics-have therefore a high degree of complementarity with the ideas themselves. This implies that ordinarily academics would license their ideas at a zero fee, and if so, since licensing is not costless, this is a further argument against copyright or patent protection of such ideas." (LANDES; POSNER, op. cit., p. 97).

164 "Questões referentes a orçamentos públicos e diferentes dificuldades orçamentárias têm feito com que os governos privilegiem as simplórias acusações à indústria farmacêutica, bem como o ataque ao regime de proteção legal dos direitos de propriedade intelectual, em vez de estancarem a verdadeira sangria de recursos públicos efetuada pela corrupção, compras mal realizadas, investimentos mal administrados e outras tantas mazelas que são de conhecimento público" (WOLFF, Maria Thereza; ANTUNES, Paulo de Bessa. Patentes de Segundo Uso Médico. Boletim Científico ESMPU, Brasília, a. III - n. 13, p. 115-131 out./dez. 2004, p. 118-119).

${ }^{165}$ GOLDSTEIN; GOLOD, op. cit., p. 1320.
} 
Este contexto gera um conflito de interesses que torna inviável sustentar um modelo com ênfase em pesquisas científicas acadêmicas que prescinda da proteção patentária, pois agentes econômicos privados poderosos estarão direta ou indiretamente envolvidos. A pesquisa científica relacionada a desenvolvimentos biotecnológicos de base nas universidades, cujos resultados teoricamente reverteriam ao uso comum e seriam difundidos de forma ampla junto à sociedade, passam assim a se sujeitar aos interesses particulares do seu agente privado financiador. Neste sentido:

"It is hard to explain the role of patents in academia using the full disclosure model, since it is not necessary to offer exclusivity incentives to a university in order to get it to publish. The raison d'etre of academic research is to publish. The financial model alone does not explain the role of patents in academia either, unless one considers it in conjunction with the "tragedy of the commons. ",166

Tal situação acaba por desvirtuar o resultado prático almejado pelos defensores de um ambiente desprovido da tutela patentária, pois tem como pressuposto justamente o fato de que os entes privados possam se beneficiar economicamente da exploração comercial dos resultados originados de tais pesquisas. Ato contínuo, retorna-se à discussão da adequação dos mecanismos que irão melhor acomodar os interesses sociais vinculados à continuidade da evolução tecnológica, em especial a forma de tratamento dos desenvolvimentos subsequentes. Sobre tal questão, HOLMAN argumenta que:

\footnotetext{
"The patented university discoveries described in this article (...) would surely have been discovered with or without the incentive of a patent. This sort of basic research is funded by grants, and the promise of publication and recognition should be enough incentive for university researchers to make and disclosure these types of discoveries. By contrast, these patents can serve as a hindrance and disincentive to the follow-on research and commercial development activities required to transform fundamental discoveries into potential lifesaving technologies" $" 167$
}

\footnotetext{
${ }^{166}$ GOLDSTEIN; GOLOD, op. cit., p. 1324.

${ }^{167}$ HOLMAN, op. cit., p. 543.
} 
Em outro nível, defende-se também a não patenteabilidade por não verificação dos requisitos autorizadores da patente. Isso porque: (a) não se atenderia ao requisito da novidade, uma vez que os genes já se encontram na natureza; (b) o material biológico não estaria sendo efetivamente transformado de forma relevante/significativa pela mão do homem, o que não demonstraria a existência de uma criação do intelecto humano capaz de ser entendida como um passo inventivo; e (c) o uso específico, além da sua própria utilização como ferramenta de pesquisas, não é via de regra apresentada.

Contudo, por tudo o quanto já se discutiu, em especial no Capítulo 3.5, nenhum desses argumentos é sustentável, tendo já sido demonstrado que os genes (sejam eles isolados/purificados, ou sinteticamente produzidos) não poderiam ser a priori excluídos da proteção patentária.

Deve-se, portanto, analisar com cautela este argumento que aponta para o desincentivo a investimentos, caso a proteção patentária não exista no caso em análise. Os direitos de propriedade intelectual afetam diretamente o retorno a investimentos realizados em determinada invenção. A chance de se obter o direito de exploração exclusiva de um determinado produto ou tecnologia ou participação em novas invenções dela originadas é um aspecto importante considerado na decisão de empresas privadas apoiarem tais projetos.

A proteção patentária é um importante vetor para se embasarem decisões de investimentos em P\&D na área biotecnológica, notadamente em razão dos elevados riscos e custos atrelados. Em vista deste contexto, BOSTYN admite não ver outra saída senão promover ações capazes de atrair os investimentos privados para um contínuo desenvolvimento tecnológico:

\footnotetext{
"This is indeed a problem which deserves thorough scrutiny, but I am afraid that it is a choice that we have already made. If we wish to find remedies for hereditary diseases, we must invest money, and the national governments cannot be of sufficient aid in order to pursue this research on a non-profit basis."
}

\footnotetext{
${ }^{168}$ BOSTYN, S. J. R. The prodigal son: the relationship between patent law and health care. Medical Law Review, 11, Primavera/2003, p. 87.
} 
Em última análise, e considerado claro o interesse social no desenvolvimento no campo da engenharia genética, pode-se dizer de modo mais simplista que o argumento a prevalecer para fins de se justificar a necessidade de proteção dos genes humanos pela via patentária é de caráter econômico.

E assim, pela aplicação de um sistema patentário que circunscreva e delimite apropriadamente o alcance que a tutela patentária biotecnológica deve possuir, as dificuldades relacionadas ao acesso/intercâmbio de informações técnico-científicas e o balanceamento dos incentivos entre inventores pioneiros e os subsequentes poderão viabilizar a promoção do desenvolvimento tecnológico à luz do interesse social.

\subsection{Extensão do âmbito de proteção dos genes no sistema patentário}

A indústria farmacêutica necessita investir centenas de milhões de dólares e anos de trabalho em P\&D para chegar a produto biotecnológico apto à comercialização, o que impõe importantes barreiras ao setor. Isso quer dizer que empresas farmacêuticas deixariam de realizar os investimentos necessários ao desenvolvimento de tratamentos e fármacos baseados na engenharia genética por inexistência de mecanismo eficaz, capaz de garantir o retorno de tais investimentos - cujas montas são deveras elevadas e possuem um risco enorme de insucesso.

Como dizem WOLFF e ANTUNES, tal situação acaba concentrando a indústria farmacêutica nas mãos de poucos:

“É necessário que se observe, no entanto, que entre o início das pesquisas para um novo produto farmacêutico e a sua efetiva comercialização, o tempo gasto é de, aproximadamente, 14 (quatorze) anos, com custos que superam, em muito, a centena de milhões de dólares americanos. $O$ volume de recursos necessários para a produção de um novo medicamento, seja do ponto de vista econômico, seja dos pontos de vista científico e tecnológico (a indústria farmacêutica é uma das indústrias mais fortemente conhecimento intensivas), faz com que somente poucos países possam pertencer a um "clube" muito fechado, pois apenas empresas podem suportar os custos e os riscos de pesquisa que se prolongam 
por mais de uma década, sem que haja qualquer segurança de que o produto delas resultante será efetivo e seguro e terá aceitação de mercado." 169

Tendo em vista o quanto acima discorrido, e demonstrada a ineficiência de um ambiente desprovido de qualquer proteção aos desenvolvimentos biotecnológicos, notadamente com relação às patentes genéticas, é possível concluir que uma tutela patentária seja desejável, inclusive sob a ótica social. A questão que se coloca neste contexto diz respeito à grande dificuldade de se alcançar um ponto ótimo no que diz respeito à amplitude da proteção patentária a ser conferida às invenções na área da biotecnologia.

A este respeito, BOSTYN entende que se, por um lado, as patentes muito restritas poderiam caracterizar desincentivos ao desenvolvimento biotecnológico, por outro lado, uma proteção muito ampla poderá limitar o desenvolvimento científico subsequente em razão dos altos custos de licenciamento dessas patentes dependentes e/ou do elevado risco de contrafação:

"If the scope of protection for the patent holder was defined narrowly, it could have negative effects in the long run on scientific research and the development of new products, because possible inventors would be less interested in exploring these fields of research, because of the low return on investment opportunities. If patent protection for this type of inventions, which could be called raw material or element inventions, is narrow, it is too easy to avoid patent infringement, and the opportunities to recoup the investment made, which is of course substantial for this type of inventions, are not sufficient. On the other hand, it could also be argued that, by providing wide scope of protection for thus type of inventions, scientific development and the "creation" of new and better products will stifle. This is because the complex situation of scope of protection will make possible inventors hesitant to enter the field, due to the possible risks of patent infringement, or the possible high costs for licensing fees. (...) On the other hand, one could also argue that the so-

\footnotetext{
${ }^{169}$ WOLFF; ANTUNES, op. cit, p. 116-117.
} 
called best solution would never see daylight in the absence of sufficient patent protection." 170

Viu-se que são passíveis de proteção patentária novos conhecimentos que aportarem uma solução concreta para um problema prático, de modo que não devem ser "premiados" os inventores que identifiquem e divulguem meras descobertas. O patenteamento da mera descoberta de sequências de DNA enquadrar-se-ia assim no princípio geral de exclusão, pois o gene per se não resolve um problema técnico-prático do homem.

Porém, uma vez identificada a existência de um produto ou processo técnico que atenda às condições de patenteabilidade, tal "invento" deve ser objeto da proteção patentária e excluir quaisquer terceiros de sua exploração econômica.

Por essa premissa, chega-se facilmente à conclusão de que o reconhecimento da possibilidade de proteção absoluta às patentes - assegurando ao seu titular a possibilidade de limitar que terceiros possam explorar as mais diversas funções a que podem se prestar, além daquelas expressamente reivindicadas pelo inventor - significaria, em última análise, premiar a mera descoberta.

Pela noção tradicional de patentes, mostra-se mais factível se sustentar uma proteção mais extensa às invenções mecânicas, pois o aspecto central da invenção é justamente o objeto físico criado, devendo sobre ele recair diretamente a proteção.

De outro lado, ao se tratar de patentes genéticas, o foco da invenção biotecnológica correspondente não está centrado na sequência do DNA enquanto produto químico, sendo esta preterida pelo conteúdo informacional por ela carreado. A informação é o aspecto mais importante das invenções biotecnológicas no campo da genética, de modo que há um deslocamento do foco para as "aplicações" que podem surgir - e não mais ao "objeto" gene, considerado em si mesmo.

\footnotetext{
${ }^{170}$ BOSTYN, S. J. R. One Patent a Day Keeps the Doctor Away? European Journal of Health Law, vol 7, $\mathrm{n}^{\circ}$ 3 Set. 2000, p. 252-253.
} 
Portanto, não se deve considerar a exclusão dos desenvolvimentos biotecnológicos do âmbito de atuação do direito patentário; muito embora a mera descoberta de uma sequência de DNA per se não seja elegível para uma patente, o resultado de um trabalho técnico nele baseado que apresente uma aplicação prática torna-a patenteável.

Neste sentido, primeiramente serão estudados os reflexos de se conferir a patente dos genes como um produto, em caráter absoluto, desde que seja indicado ao menos um uso prático de caráter inventivo para o objeto da patente reivindicada - caso em que a exclusividade estender-se-ia para todos os usos que excedem aqueles originalmente identificados.

Serão neste ponto analisadas as questões relacionadas à eventual concentração do poder econômico ao detentor das patentes pioneiras na engenharia genética, bem como os arranjos comerciais que deverão se originar desta situação, a fim de se permitir uma contínua evolução de tão importante setor do conhecimento. Com base nessas premissas, concluir-se-á pela existência ou não de potenciais incentivos advindos de tal tutela - que sejam capazes de justificá-la.

Em seguida, discutir-se-á a alternativa da concessão, em caráter absoluto, relativa às patentes genéticas como possível forma de se acomodarem os diversos interesses e assim se permitir o contínuo desenvolvimento técnico-científico em âmbito biotecnológico.

Como será visto a seguir, negativas são as consequências originadas de uma tutela mais ampla - tendo em vista a potencial limitação ao desenvolvimento tecnológico subsequente. Por tal motivo, determinar a extensão das patentes genéticas aparenta ser uma escolha menos radical capaz de acomodar os mais diversos interesses: a concessão de patentes mais específicas poderá limitar a proteção patentária à sua efetiva contribuição.

\subsubsection{Proteção patentária absoluta}

Via de regra, a concessão de uma patente compreende todo e qualquer uso referente ao objeto protegido. A identificação de outras funções/finalidades que venham a ser 
atribuídas por outros cientistas poderão, pois, estar subordinadas aos detentores dessas patentes originais. Ao menos assim se entendia no passado, no contexto das invenções mecânicas, marcadas por objetos tangíveis.

Entretanto, tal solução não parece ser a mais acertada no caso das invenções em biotecnologia - em especial relacionadas a genes, em razão de seu conteúdo informacional -, como será visto a seguir. Importa, neste caso, a discussão a respeito da possibilidade de se conceder a patente em caráter absoluto, desde que seja indicado ao menos um uso prático para o objeto da patente reivindicada.

Segundo a teoria Coasiana ${ }^{171}$, a concessão de amplos direitos de propriedade para um invento pioneiro não criaria em princípio um problema, uma vez que o detentor de tal patente pioneira e o detentor da patente de melhoria barganhariam de forma a chegar a um resultado para uso eficiente. Neste contexto, ambas as partes teriam incentivos para alcançar um acordo, desde que a invenção subsequente aumente as chances de sucesso comercial da patente original. Além do mais, a concentração da titularidade de invenções pioneiras em um único agente permitiria o gerenciamento e a coordenação dos seus possíveis desenvolvimentos de modo mais eficiente.

Em que pese seja economicamente consistente tal argumento, ele deve ser visto com ressalvas. É importante notar que, no caso das patentes genéticas, o fato de que um único gene poderá originar diversas aplicações práticas/úteis não necessariamente quer dizer que invenções subsequentes originadas de um mesmo gene são dependentes. Desenvolvimentos técnico-científicos independentes e não subordinados a uma função prática anteriormente descrita para fins de se justificar a concessão de uma determinada patente genética devem ser verificados, de modo que não se mostra economicamente justificável que o inventor "pioneiro" seja beneficiado em tal situação.

Apenas em relação às patentes subsequentes que possuam um mesmo gene comum e cujos resultados práticos/aplicações sejam inter-relacionados, a patente genética

\footnotetext{
171 "A natural starting point when discussing the property/liability rule distinction, or indeed any aspect of entitlements, is the Coase Theorem. The Theorem says that in a world with zero transaction costs, initial rights allocations are unimportant; they will be transferred to their highest value use through private bargains." (MERGES, Robert P. Of Property Rules, Coase, and Intellectual Property. Columbia Law Review, 1994, p. 2656).
} 
originalmente patenteada poderá ter ascendência sobre aquela subsequente. Nessas situações, contudo, deve-se primeiro verificar se a relação entre patentes pioneiras e dependentes envolvem ou não parcelas essenciais da invenção. Caso não se refiram a porções essenciais, uma proteção patentária absoluta no âmbito de invenções genéticas poderá gerar uma descabida vinculação do inventor subsequente ao inventor pioneiro ${ }^{172}$.

É neste ponto, portanto, que surgem os problemas referentes à apropriação dos genes em relação enquanto objetos inseridos no ambiente de proteção patentária. Isso se deve ao fato de que a concessão da patente a sequências de DNA poderia cobrir não apenas as funções específicas que foram expressamente reivindicadas no ato do requerimento de sua proteção, mas qualquer outra futura aplicação.

O patenteamento de genes poderia assim significar o irrestrito controle de todo o seu conteúdo informacional (que deve possuir incontáveis aplicações possíveis, obviamente desconhecidas em sua totalidade no momento do requerimento da patente). A consequência desta prática deve ser analisada, pois isso poderá ter implicações para inovações atuais e subsequentes.

Em primeiro lugar, em matéria de patentes dependentes, muito embora tenham como pressuposto o desenvolvimento de uma nova tecnologia que envolva o interesse social, fato é que os relacionamentos entre inventores pioneiros e subsequentes geram naturalmente um efeito cascata nos pagamentos das licenças que devem ser concedidas.

O acúmulo de royalties eleva o preço dos produtos finais, bem como aumenta a burocracia e os custos de transação para o desenvolvimento de novas pesquisas. As indústrias farmacêuticas que desenvolvem fármacos baseados em tecnologia gênica veem aqueles que detém as patentes sobre ferramentas/instrumentos relativos a pesquisas de base

\footnotetext{
172 "This fear is not completely justified. First of all, it is clear that all patentability requirements must be fulfilled in order to obtain patent protection. In other words, if a patent application is filed without any practical use for the invention, or without the invention being completely and sufficiently disclosed, no patent will be granted. Secondly, if there is overlap between the sequence claimed by a first and subsequent inventor, according to recital (25) of the directive [Directive 98/44], for the purposes of interpreting rights conferred by a patent, when sequences overlap only in parts which are not essential to the invention, each sequence will be considered as an independent sequence in patent law terms'. This implies that the second invention will not be considered as a dependent invention, thus not requiring a license from the first inventor in order to carry out the invention." (grifos nossos) (BOSTYN, 2000, op. cit, p. 234)
} 
como "cobradores de impostos". Naturalmente, todos esses custos adicionais originados de um desenvolvimento dependente deverão ser arcados pelos consumidores finais.

\begin{abstract}
"It can indeed not be denied that, in order to do further research with the aid of patented inventions, with a view to obtain new commercial products, licensing fees have to be paid. And finally, the consumer or patient will have to pay for this, if the innovator still wants to recoup his own investments." ${ }^{173}$
\end{abstract}

Mesmo reconhecendo-se pela existência de vantagens na centralização de uma patente, em razão de uma possível maior eficiência na alocação dos recursos financeiros e humanos (que de outra forma seriam descoordenados, replicados e sobrepostos), BOSTYN apresenta um cenário problemático que não deve ser ignorado, que diz respeito às situações em que uma patente determinada não pode ser acessada facilmente:

\begin{abstract}
"Evidently, problems can arise when inventions are not accessible without the cooperation of the patent holder, or situations where the invention cannot be copied in the laboratory, but must be bought. In such events, the price to use the invention will be a monopoly price, and thus higher than the market price in the absence of a monopoly." 174
\end{abstract}

Claro que a lei irá regular situações em que se verifica um abuso desta posição por meio da licença compulsória. Como já tratado no Capítulo 3.6.4, a licença compulsória permite ao Estado a concessão do direito de exploração do bem patenteado por terceiros sem o prévio consentimento do proprietário da patente, para fins de atendimento ao interesse público ${ }^{175}$.

Em qualquer caso, porém, políticas que criem essa hierarquia econômica e tecnológica, subjugando os desenvolvedores subsequentes, muito provavelmente acarretarão desestímulo ao investimento em tais novas tecnologias pelo simples fato de

\footnotetext{
${ }^{173}$ BOSTYN, 2003, op. cit., p. 86.

${ }^{174}$ Idem.

175 "Dependency licenses concern the situation where the holder of a prior invention refuses to grant a license to the holder of a patent on an invention which is new, but derived from the initial invention. By this refusal, which may be motivated by the desire to maintain his position in the face of competition, he prohibits use of the secondary invention. In this case, the judge may grant a license to the holder of the improvement patent and decide on the amount of license fees. The secondary invention must represent a technical advance and certain economic value compared with the initial invention." (FRANCHITTO, N; GAVARRI, L; TELMON, N; ROUGÉ, D. Comment on the provisions of the French laws of 6 August 2004 and 8 December 2004 relative to the protection of genetic inventions. Med Law, vol 25, n. 2, Jun. 2006, p. 385).
} 
serem economicamente inviáveis, freando o passo do desenvolvimento técnico-científico. Deste modo, não há dúvidas de que a compreensão do panorama tecnológico em termos de patentes é um processo complexo, principalmente para novos agentes que estão tentando se inserir no mercado, situação esta que é bastante saudável e deve ser incentivada como forma de promoção de uma livre e saudável concorrência. Os problemas de antitruste, em especial, são uma possibilidade real ${ }^{176}$.

À parte disso, importa lembrar que muitas vezes ocorrem sobreposições parciais ou totais na funcionalidade dos componentes, o que faz com que as patentes que os protegem também possam se sobrepor. Esta tem sido uma estratégia utilizada para ampliar a proteção dos interesses dos pesquisadores e seus financiadores privados, especialmente em áreas de tecnologia de ponta onde os investimentos em P\&D são relevantes, situação esta identificada como patent thicket:

\begin{abstract}
"Strategic planning often involves identifying key areas that represent technology bottlenecks. Once identified, the patentability of such a bottleneck is evaluated. Assuming patentability, each bottleneck should be protected by a cluster of patents, with at least one patent providing broad generic protection for the cluster. Additional patents should protect specific attributes of the bottleneck that represent potential entry points for competitors. Multiple patents create a more formidable barrier than a single patent. A potential infringer would be more reluctant to ignore five or six relevant patents than just one. The odds favor the patent holder in this situation, because it is very difficult and expensive to prove lack of infringement or invalidity of numerous relevant patents." ${ }^{177}$ (grifo nosso).
\end{abstract}

Um patent thicket (“emaranhado de patentes”) consiste em patentes criadas para proteger componentes de uma tecnologia complexa e modular. Neste contexto, "modular" significa que os diferentes conjuntos de componentes podem ser utilizados em uma variedade de produtos tecnológicos, não apenas no produto original, para o qual foi criado.

\footnotetext{
${ }^{176}$ Essa é uma questão levantada até mesmo pela FTC Americana: "However, antitrust concerns may arise when a licensing arrangement harms competition among entities that would have been actual or likely potential competitors in a relevant market in the absence of the license (entities in a horizontal relationship')". (Estados Unidos. Department of Justice and Federal Trade Commission. Antitrust Guidelines for the Licensing of Intellectual Property, \$3.1. Disponível em http://www.justice.gov/atr/public/guidelines/0558.htm. Acesso em 14/12/2014).

${ }^{177}$ MEYERS, Thomas C.; TURANO, Thomas A.; GREENHALGH, Duncan A.; WALLER, Patrick R.H. Patent protection for protein structures and databases. Nature Structural Biology, Nov/2000, p. 952.
} 
Já por "complexo" se entende que esses produtos envolvem dezenas ou centenas de componentes modulares.

$\mathrm{Na}$ definição de SHAPIRO ${ }^{178}$, trata-se de "a dense web of overlapping intellectual property rights that a company must hack its way through in order to actually commercialize new technology". Trata-se de prática/estratégia empresarial que, ao contrário do que pode aparentar, tem o potencial de restringir o acesso às informações e gerar desincentivo aos inventores subsequentes, situação na qual as consequências acima levantadas se repetirão. A este respeito, GOLDSTEIN e GOLOD são favoráveis às patentes como estímulo à concorrência e criticam, indiretamente, situações de patent thicket:

\begin{abstract}
"There is no doubt that when an important human gene patent issues, the competitors of the owner go into high gear in their attempts to invalidate the patent and/or to circumvent and design around it. 'Inventing around' is an activity that benefits society in that it leads to technological advances. It is one of the positive consequences of a healthy patent system" $" 179$ (grifos nossos).
\end{abstract}

Não se deve descartar, outrossim, os elevados riscos relacionados à contrafação de patentes originados de concessões patentárias muito amplas, especialmente no contexto das patent thickets, a que ficam expostos os inventores subsequentes. Tal fato assume ponto de fundamental importância na decisão de realizar investimentos em $P \& D$, tendo em vista as possíveis contingências atreladas a determinadas linhas de pesquisa, decorrentes de eventual sobreposição substancial de objetos/produtos integrantes de patente previamente concedida $^{180}$.

\footnotetext{
${ }^{178}$ SHAPIRO, Carl. Navigating the Patent Thicket: Cross Licenses, Patent Pools, and Standard Setting. In: JAFFE, Adam B.; LERNER, Josh; STERN, Scott (org.). Innovation Policy and the Economy, vol. 1. Cambridge: MIT Press, 2001, p. 119-150, p. 120.

${ }^{179}$ GOLDSTEIN; GOLOD, op. cit, p. 1322.

180 "Ultimately it is important to bear in mind that every potential inventor is also a potential infringer. Thus a 'strengthening' of property rights will not always increase incentives to invent; it may do so for some pioneers, but it will also greatly increase an improver's chances of becoming enmeshed in litigation. Indeed this is the very heart of our case. When a broad patent is granted or expanded via the doctrine of equivalents, its scope diminishes incentives for others to stay in the invention game, compared again with a patent whose claims are trimmed more closely to the inventor's actual results. The same is true of a patent granted unduly broad scope by the patent office. This would not be undesirable if the evidence indicated that control of subsequent developments by one party made subsequent inventive effort more effective. But the evidence, we think, points the other way." (MERGES, Robert P.; NELSON, Richard R. On the Complex Economics of Patent Scope. Columbia Law Review, 1990, p. 864-865).
} 
A noção de que o detentor de uma determinada invenção deve controlá-la de modo ilimitado, independentemente da forma pela qual ela é produzida, pode fazer sentido para invenções mecânicas; entretanto, o mesmo não se pode dizer no âmbito da biotecnologia pelo simples fato de que os genes são matérias-primas básicas de pesquisa que não poderiam ser substituídas.

\begin{abstract}
"According to the ordinary bedrock rules of patent law, it is not allowed to use a patent product or process without the permission of the patent holder. Let us take the example of a gene therapy protocol which is now in the phase of being approved for clinical trials. Assume that the gene therapy protocol makes use of a patented vector in order to transport the gene of interest into the human body and bring it to the place where it can be activated and perform its useful function. If the patented vector is used without the permission of the patent holder, then a patent infringement is committed. It will thus be necessary to obtain a license from the patent holder. (...) this can be considered an additional burden to those who wish to develop gene therapies and/or pursue clinical trials." ${ }^{181}$
\end{abstract}

Essa situação certamente aumenta a dificuldade de se promover o desenvolvimento biotecnológico em genética, de modo que a limitação da proteção patentária vinculada à descrição contida de forma explícita e suficiente na reivindicação patentária pode conferir a tal forma de proteção legal uma fundamentação econômica capaz de justificá-la ${ }^{182}$. É o que a seguir será demonstrado.

\footnotetext{
${ }^{181}$ BOSTYN, 2003, op. cit., p. 86.

182 "The problem of purified natural product patents also deserves mention. As we have seen, product patents are often granted on purified forms of compounds that occur naturally. Subsequent recombinant versions of the compounds are therefore blocked from effective protection, as in the case of Scripps Clinic \& Research Foundation v. Genentech, Inc. While there is reason to believe that the instances of this kind have multiplied in recent years, we have noted that the tradition of granting a product rather than a process patent goes back as far as Parke-Davis \& Co. v. H.K. Mulford \& Co., when Learned Hand upheld a product patent on purified human adrenalin. In such cases protection consistent with the actual achievement of the inventor would have been provided if the initial patent had been for a process, or at most a "product-by-process," rather than for a product. And inventive efforts to come up with a significantly better process to make the product would not be blocked. These concerns seem to have animated a recent British case denying broad claims for Genentech's t-PA drug. One (perhaps controversial) way to achieve this would be to recognize a reverse equivalents defense when a recombinant product is accused of infringing a prior purification patent. Also, awarding these more limited patents would be much more consistent with the enablement doctrine; the principle there is to allow the inventor only what she has actually invented as described in the principle spelled out in the specification." (MERGES; NELSON, op. cit., p. 864).
} 


\subsubsection{Proteção patentária relativa}

A alternativa mais adequada parece ser a limitação do escopo da patente apenas para a função expressamente descrita na reivindicação da proteção patentária pretendida, considerando-se admissíveis as patentes de segundo uso para casos desta natureza. Com reivindicações apropriadamente limitadas, patentes envolvendo genes humanos aparentemente não seriam problemáticas, uma vez que estariam limitadas ao estado da técnica e ao escopo da divulgação feita pelo inventor.

Se a lógica do sistema patentário busca premiar os resultados práticos em virtude de procedimentos técnicos que somente o ser humano é capaz de realizar (e que a natureza por si mesma não terá condições de reproduzir), é coerente circunscrever a exclusividade apenas a esta situação. Não há porque a mera descoberta de um produto ou processo natural, quando desacompanhada de um aporte prático, justifique a exclusividade de exploração.

Neste contexto, para além de ser a aplicação prática das patentes biotecnológicas um requisito essencial para garantir sua proteção, deve-se também levar em consideração que nesta esfera do conhecimento os inventores podem se basear em um mesmo fenômeno natural, lei ou produto da natureza (ou fenômeno natural) para originar divergentes aplicações práticas - que poderão ser dependentes ou autônomas.

Deste modo, o alcance de referida proteção deverá estar limitado à aplicação particular para a qual sua invenção foi concebida. Nesse diapasão, VINAROV esclarece que os escritórios nacionais de proteção à propriedade industrial dos EUA, UE e Japão possuem diretrizes similares no sentido reconhecer tais patentes, desde que os requisitos de patenteabilidade sejam identificados:

"Likewise, the three patent offices [U.S., European and Japanese Patent Offices] shared the view that an isolated and purified polypeptide consisting of a portion of a protein with signaling activity meets all the requirements of patent eligible subject matter, statutory invention, industrial applicability (application), utility, enablement, support, clarity, written description, novelty, inventive step and nonobviousness since (a) it is limited to a fragment of the protein that contains the binding pocket and was shown in the specification to retain binding 
activity and the signaling activity of the protein, and (b) the prior art does not teach any polypeptide which consists of the claimed specific part of the protein, or methods to specify parts of the polypeptide, and (c) it shows a significantly higher signaling activity compared to the whole protein." 183 (grifo nosso)

Assim, produtos originados de um mesmo elemento e/ou processo biotecnológico, dotados de funções diversas, poderão ser considerados independentes, desde que possuam aplicações distintas e autônomas e não haja qualquer relação entre eles que possa caracterizar predominância entre aquela patente pioneira e a subsequente, que tenha naquela se apoiado. Neste sentido, MEYERS entende que:

"In theory, a new protein structure may still be patentable even if the structures of homologous proteins, such as naturally occurring isoforms or species or allelic variants, are known. However, the scope of any available patent protection may be very narrow, because the new protein structure must meet all the statutory requirements discussed above, including novelty and nonobviousness. In practice, significant protection will most likely be available only if the new protein structure has sufficient features to render it novel and nonobvious in view of the known structures.

It is important to understand that patent protection may also be available for a new protein structure even if another patent has already issued with claims to the general features of the new protein structure (for example the general structural features of a protein family). Again, the new protein structure must have novel and non-obvious structural features in order to obtain patent protection in view of the issued patent. Remember that a patent does not give the patent holder the right to practice the claimed invention, it only gives the patent holder the right to exclude others from practicing the claimed invention. Under this scenario, the previously issued patent is referred to as a dominant patent. This means that even if patent protection is obtained for the new protein structure, use of that protein structure may infringe the claims of the previously issued patent. However, the owner of the previously issued patent would not be entitled to infringe the claims of the patent on the new protein structure." 184 (grifo nosso)

\footnotetext{
${ }^{183}$ VINAROV, Sara D. Patent Protection for Structural Genomics-related Inventions. Journal of Structural and Functional Genomics, vol. 4, 2003, p. 206.

${ }^{184}$ MEYERS et al, 2000, op. cit. p. 951.
} 
Desta forma, o produto desta "invenção" estaria limitado ao estado da técnica, acrescida da contribuição do inventor, e nada mais. As patentes teriam um alcance mais restrito, caracterizando-se uma relação de dependência apenas quando restar demonstrado de forma inequívoca que

\begin{abstract}
"Furthermore, patent protection should also be available for an isolated protein based on its gene sequence, provided that the patent application contains sufficient information to show that an isolated protein meets the statutorily defined U.S. guidelines (i.e., the protein is useful and the method of making and/or using it have been enabled). However, it is noted that such earlier patents, based on a gene sequence information, may dominate some of the claims in subsequent protein structure patents and perhaps prevent the later from freedom to operate. In other words, depending on the specific facts of the case, the owner of the later protein structure patent may not be able to practice their invention without infringing the patent claims directed to an isolated protein based on its gene sequence. As such, the owner of the later protein structure patent would need to contractually negotiate (i.e., possibly through a crosslicense) use of the claimed protein invention with the owner of the earlier gene patent or risk being the subject of and infringement lawsuit." ${ }^{185}$ (grifo nosso)
\end{abstract}

Esta forma de patenteamento iria manter os incentivos para as pesquisas em genética, evitando que os detentores das patentes possam se apropriar de produtos naturais, tais como os genes na forma em que se encontram no corpo humano - ainda que dele isolados e purificados.

A proteção deve ser cabível, mas apenas para as aplicações descritas e comprovadas no pedido de patente. Dessa forma, permite-se que outros inovadores encontrem novas aplicações e novos processos de isolamento de material biológico, podendo explorá-los economicamente e protegê-los por patentes, preenchidos os requisitos legais.

A adoção da tutela patentária relativa às invenções tecnológicas poderia, portanto, ser viável na medida em que conceder os incentivos suficientes a viabilizar investimentos necessários ao desenvolvimento da biotecnologia, porém, limitando o seu detentor à contribuição por ele de fato realizada.

${ }^{185}$ VINAROV, op. cit., p. 195. 
Dentro deste contexto, as patentes de segundo uso passam a ter um importante papel no âmbito das proteções intelectuais no campo biotecnológico.

\subsubsection{Patentes de segundo uso}

O termo "segundo uso" no contexto do sistema patentário refere-se ao desenvolvimento de uma nova aplicação para um produto ou processo já existente, desde que tal novo uso seja dotado de novidade, aplicação industrial e atividade inventiva.

Neste caso, a novidade seria aferida pela existência de uma nova aplicação de produto ou processo biotecnológico conhecido, que se preste a solucionar um problema técnico distinto do estado da técnica descrito na reivindicação patentária precedente, originada deste mesmo produto/processo biotecnológico. A atividade inventiva seria observada por novo mecanismo de ação, reivindicação de função e/ou aplicabilidade não afeta ao estado da técnica. Para tanto, o pedido deve estar recoberto de suficiência descritiva na demonstração de tal novo uso ao objeto/produto precedente.

A patente de segundo uso farmacêutico ou médico é aquela requerida para a aplicação nova de substâncias, princípios ativos, moléculas ou composições previamente conhecidas, porém inicialmente utilizadas para outro fim ${ }^{186}$.

A título ilustrativo, importa mencionar o caso da aspirina como um dos mais emblemáticos no que tange a pesquisas de segundo uso; em tal situação, a consequência prática dos desenvolvimentos subsequentes relacionou-se à possiblidade de utilização diversa daquela à qual o medicamento originalmente se prestava: o composto, denominado ácido acetilsalicílico (AAS), que servia como medicação antiinflamatória e antitérmica, passou a ser utilizado para fins de prevenção na formação de coágulos na corrente sanguínea $^{187}$.

\footnotetext{
${ }^{186}$ LEITE, Márcio de Oliveira Junqueira. O patenteamento de invenções de segundo uso no Brasil. 27/04/2011. Dissertação (Mestrado em Direito) - Faculdade de Direito da Universidade de São Paulo. São Paulo, 2011, p.9.

${ }^{187} \mathrm{Um}$ dos principais efeitos do AAS identificado por pesquisas subsequentes foi a atuação na prevenção da formação de coágulos na corrente sanguínea, os quais demonstraram não só seu uso na prevenção e no tratamento de infartos do miocárdio como em doenças cerebrovasculares
} 
JANNUZZI, VASCONCELLOS e SOUZA diferenciam a patente de primeiro uso médico ${ }^{188}$ da patente de segundo uso médico ${ }^{189}$. A concessão de patentes de segundo uso médico passou a ser reconhecida e aplicada no ano de 1984, com a decisão do Enlarged Board of Appeal do EPO de $\mathrm{n}^{\circ} \mathrm{G} 0005 / 83$ :

"IV. By a further written communication, the Enlarged Board of Appeal indicated that, for stated reasons, it did not consider that an affirmative answer could be given to the question of law put by the Technical Board of Appeal for Chemistry. However, attention was drawn to a recently adopted statement of practice regarding "use claims" issued by the Swiss Federal Intellectual Property Office, in accordance with which (inter alia) a claim to the use of an active ingredient for the manufacture of a medicament ready for administration could be allowed even where it related to the second (or further) application for a known pharmaceutical composition. The Enlarged Board of Appeal stated that it considered that it was also necessary to decide whether this kind of claim was acceptable under the European Patent Convention.

12. Whilst, therefore, there can be no objection to 'use claims' in general, the obvious objection to a patent 'with claims directed to the use' being granted for 'the use of a substance or composition for the treatment of the human or animal body by therapy' is that it seems to be in direct conflict with the provisions of Article 52(4) EPC, in accordance with which 'methods for treatment of the human or animal body by therapy ... shall not be regarded as inventions which are susceptible of industrial application' within the meaning of Article 52(1) EPC.

22. The intention of Article 52(4) EPC, again as recognised by the Federal Court of Justice, is only to free from restraint non-commercial and nonindustrial medical and veterinary activities. To prevent the exclusion from going beyond its proper limits, it seems appropriate to take a special view of the concept of the 'state of the art' defined in Article 54(2) EPC. Article 54(5) EPC alone provides only a partial compensation for the restriction on patent rights in

188 "um novo uso, como medicamento, de produto já conhecido como utilização fora do âmbito medicinal" (JANNUZZI, Anna Haydée Lanzillotti; VASCONCELLOS, Alexandre Guimarães; SOUZA, Cristina Gomes. Especificidades do patenteamento no setor farmacêutico: modalidades da proteção intelectual. Revisão, cad. Saúde Pública, Rio de Janeiro, vol. 24, nº 6, junho/2008, p. 1213)

189 "uma nova aplicação terapêutica de um produto conhecido como medicamento" (idem). 
the industrial and commercial field resulting from Article 52(4) EPC, first sentence. It should be added that the Enlarged Board does not deduce from the special provision of Article 54(5) EPC that there was any intention to exclude second (and further) medical indications from patent protection other than by a purpose-limited product claim. The rule of interpretation that if one thing is expressed the alternative is excluded (expressio unius (est) exclusio alterius), is a rule to be applied with very great caution as it can lead to injustice. No intention to exclude second (and further) medical indications generally from patent protection can be deduced from the terms of the European Patent Convention: not can it be deduced from the legislative history of the articles in question. On this last point, after conducting its own independent studies of the preparatory documents, the Enlarged Board finds itself also in accord with the conclusion of the Federal Court of Justice." ${ }^{190}$ (grifo nosso)

De fato, os órgãos estrangeiros de propriedade intelectual têm atualmente reconhecido o patenteamento do segundo uso de modo bastante amplo, sendo admitido mesmo em situações nas quais a única diferença entre a patente nova e a antiga é a dosagem do composto, como foi se verificou no caso processo G 0002/08, decidido 2010 pelo Enlarged Board of Appeal do EPO da seguinte forma:

\begin{abstract}
"Where it is already known to use a medicament to treat an illness, Article 54(5) EPC does not exclude that this medicament be patented for use in a different treatment by therapy of the same illness. (...) Such patenting is also not excluded where a dosage regime is the only feature claimed which is not comprised in the state of the art. (...) Where the subject matter of a claim is rendered novel only by a new therapeutic use of a medicament, such claim may no longer have the format of a so called Swiss-type claim as instituted by decision G 5/83"191
\end{abstract}

O Brasil atualmente não compartilha da mesma realidade de forma expressa, sendo a LPI silente quanto à proteção ao "uso", que não prevê especificamente reivindicações dessa espécie. Tal fato pode ser interpretado de duas formas: (a) o artigo 42 da LPI define as categorias de reivindicações, consequentemente, reivindicações de uso estão inexplícitas e não seriam passíveis de privilégio; ou (b) as definições do artigo em tela não são

\footnotetext{
${ }^{190}$ European Patent Office. Decisão no G0005/83 de 5 de dezembro de 1984: second medical use indication. Disponível em: http://www.epo.org/law-practice/case-law-appeals/recent/g830005ep1.html. Acesso em: 20/12/2014.

${ }^{191}$ European Patent Office. G 0002/08 (Dosage regime/ABBOTT RESPIRATORY) of 19.2.2010. Disponível em: http://www.epo.org/law-practice/case-law-appeals/recent/g080002ex1.html. Acesso em: 09/12/14.
} 
limitativas, tornando as reivindicações de uso privilegiáveis ${ }^{192}$. Esta última interpretação parece ser a mais acertada, tendo em vista que se adota no Brasil o sistema genérico de classificação, conforme ensinam WOLFF e ANTUNES:

\footnotetext{
"No que se refere à aceitação de reivindicações de uso no Brasil, é importante mencionar que desde a Lei da Propriedade Industrial de 1945 o Brasil adota o sistema chamado genérico de classificação, ou seja, tudo que não está expressamente mencionado na Lei como não-patenteável é passivel de proteção."193
}

É exatamente por esse motivo que a jurisprudência nacional tem admitido uma intepretação não limitativa à proteção patentária, muito embora a patente de uso não seja expressamente prevista na LPI. Em 2013, foi decidido pelo Tribunal Regional Federal da $2^{\mathrm{a}}$ Região (TRF-2) o cabimento de patente voltada a um uso novo de um composto antigo - entendeu-se que, a princípio, tudo que não é indicado pela LPI como não passível de patenteamento poderia se qualificar para a proteção:

“PROPRIEDADE INDUSTRIAL - REGISTRO DE PATENTE DE SEGUNDO USO - POSSIBILIDADE EM TESE - NÃO PREENCIMENTO DOS REQUISITOS DO ARTIGO $8^{\circ}$ DA LEI 9.279/96 NO CASO CONCRETO. 1 - O Brasil contempla a propriedade intelectual privada desde a Constituição, mas de acordo com os incisos XXIX, XXII e XXIII do art. 5o, sendo certo que na legislação vigente, no que concerne às patentes, em regra vige o sistema genérico de classificação onde tudo que não está relacionado de forma expressa na Lei como não patenteável, em princípio seria passível de proteção, o que em tese autorizaria o registro das denominadas patentes de segundo uso. 2 Necessidade de aferição, caso a caso, dos requisitos de patenteabilidade. 3 Novidade se vê esvaziada na medida em que embora não tenha sido anteriormente descrito o uso da substância para o TDAH e não tenha havido notícias de pesquisas sobre ela para uso em tal doença a substância já era conhecida como inibidora de substância que interferia em outra doença neurológica, não parecendo de todo impossivel a um técnico derivar sua utilização também para outras doenças do mesmo gênero. 4 - Inventividade que não se pode extrair dos autos, na medida em que não bem demonstrados os

\footnotetext{
192 JANNUZZI; VASCONCELLOS; SOUZA, op. cit., P. 1214.

${ }^{193}$ WOLFF; ANTUNES, op. cit., p. 121.
} 
passos dados para a determinação da dosagem, os efeitos empiricos no ser humano etc. 5 - Embargos infringentes conhecidos e improvidos" ${ }^{\prime 194}$.

Da mesma forma se posiciona BARBOSA, ao identificar o elemento da novidade na função, na "relação entre o meio e o resultado"195, reconhecendo - inclusive - a possibilidade de patenteamento de um composto no estado da técnica, desde que seja demonstrada a novidade em sua aplicação.

O reconhecimento desta possibilidade no âmbito das patentes farmacêuticas implica a possibilidade de sua adequação também para os casos de patentes biotecnológicas, em especial no âmbito da engenharia genética. Ora, como já visto, o conteúdo informacional dos genes é o motivo central e principal - senão o único - de sua reivindicação patentária, o que obviamente reflete na questão da utilidade/aplicação que deles se pode extrair.

Sob este prisma, JANNUZZI, VASCONCELLOS e SOUZA defendem a possibilidade da concessão de patente genética, que poderia abarcar inclusive os usos originados de genes isolados/purificados por meio da patente de segundo uso, muito embora a LPI exclua expressamente a proteção patentária aos genes isolados per se:

\footnotetext{
“Já que o INPI concede patentes de segundo uso médico, este fato deve constituir uma oportunidade para proteção patentária das pesquisas de desenvolvimento de novos usos terapêuticos de moléculas oriundas da flora brasileira. Apesar da legislação nacional impedir a proteção de produtos isolados da natureza, quando o homem confere uso prático a esses produtos, o uso passa a ser patenteável. Essa flexibilidade possibilita participação mais efetiva dos inventores nacionais de fitoterápicos na apropriação do conhecimento associado à biodiversidade."196
}

Esta abordagem se mostra factível sob a perspectiva de que a patente de segundo uso deverá assegurar somente o segundo uso em si (pois é este que deve preencher os requisitos de novidade, atividade inventiva, aplicação industrial), e não a fórmula do composto já existente (i.e. a sequencia de DNA isolada que lhe originou).

\footnotetext{
194 TRF-2, $1^{\text {a }}$ Seção Especializada. Embargos infringentes no 420502 / 200551015078111. J. 25/04/2013, EDJF2R 07/06/2013.

${ }^{195}$ BARBOSA, 2010, op. cit., p. 1272.

${ }^{196}$ JANNUZZI; VASCONCELOS; SOUZA, op. cit., p. 1214.
} 
Permitir o patenteamento do segundo uso seria um passo natural na proteção patentária brasileira, especialmente no que tange às patentes biotecnológicas. $\mathrm{O}$ fato de que diversas aplicações práticas podem se originar de um mesmo produto ou processo biológico não necessariamente quer dizer que ele carece da novidade; ora, no mais das vezes tais desenvolvimentos são originados de projetos de $\mathrm{P} \& \mathrm{D}$ distintos e autônomos, que sequer podem ser considerados dependentes - tendo apenas como elemento em comum uma mesma ferramenta de base: os genes.

De acordo com WOLFF e ANTUNES:

“Aqueles que são contra as reivindicações de segundo uso médico alegam que, uma vez que o composto já não é novo, a simples constatação de um novo efeito não conferiria possibilidade de patenteamento a esse novo uso. E incluiriam como simples descoberta! Evidentemente, esquecem que grande parte dos custos em pesquisas para lançamento de um novo medicamento não se dá na obtenção de uma nova molécula, mas sim na verificação do(s) efeito(s) dessa molécula em testes pré-clínicos e clínicos. (...)"197

Entender de forma diversa implicaria dizer que o Brasil estaria andando na contramão das orientações que já vêm sendo amplamente aceitas pela jurisprudência/doutrina norte-americana e europeia, o que posicionaria o Brasil de forma desvantajosa em termos de investimento em tecnologia.

Como o INPI faz parte do sistema patentário, que tem por finalidade incentivar o surgimento de inovações inventivas de forma a promover o desenvolvimento técnicocientífico (claramente expressado pelo artigo $2^{\circ}$ da LPI), outra não poderia ser sua visão quanto às patentes de segundo uso, senão a aceitação da reivindicação de uso na fórmula suíça (swiss-type claim) ${ }^{198}$.

\footnotetext{
${ }^{197}$ WOLFF; ANTUNES, op. cit., p. 122-3

${ }^{198}$ Diretrizes para o Exame de Pedidos de Patente nas Áreas de Biotecnologia e Farmacêutica Depositados após 31/12/1994 (RPI, 6 ago. 2002): “(...) 2.39.2.2. Reivindicações do tipo: c) Composição farmacêutica caracterizada por conter o produto $X$ (eventualmente com outros componentes), d) Composição para o tratamento da doença $Y$ caracterizada por conter o produto X (eventualmente com outros componentes), e) Composição caracterizada por conter o produto $X$ (eventualmente com outros componentes) para uso no tratamento da doença $Y, f)$ Composição na forma de tablete, gel, solução injetável, etc., caracterizada por conter o produto X (eventualmente com outros componentes) para uso no tratamento da doença, podem ser concedidas, desde que as composições a que dizem respeito sejam novas e apresentem atividade inventiva.
} 
Não há, no entanto, consenso sobre a concessão de patentes de segundo uso. A ANVISA, órgão responsável por “validar” patentes que possam impactar na saúde pública, manifestou-se de forma contrária às patentes de segundo uso: a Diretoria Colegiada da ANVISA, em 25 de agosto de 2004, por meio de uma nota técnica, considerou que o novo uso de substâncias seria lesivo à saúde pública e ao desenvolvimento científico, decidindo pela "não concessão da anuência prévia a casos de pedidos de patentes de segundo uso".

Como lembra BARBOSA em parecer de setembro de 2004, no direito administrativo brasileiro, a expressão "anuência” implica exercício de juízo de conveniência e oportunidade, i.e., de manifestação discricionária da vontade administrativa $^{199}$. Assim tem sido a interpretação da Anvisa, conforme a análise de documentos.

Ademais, na já mencionada decisão do TRF-2, entendeu-se pela interpretação restritiva do art. 226-C da Lei 9.279/96, considerando-se que "a melhor interpretação do alcance do art. 229-C é no sentido de que a anuência prévia da Anvisa restringe-se à proteção da saúde da pública, nos termos do art. $6^{\circ}$ e $8^{\circ}$ da Lei. 9.782/99”.

As patentes de segundo uso podem ser consideradas, desta forma, um importante incentivo para que se continue investindo em pesquisas nas inovações primárias, incluindo aperfeiçoamentos do medicamento original, e.g. desenvolver dosagens menores para o uso de anticoncepcionais (o que diminuiria a possibilidade do surgimento de efeitos colaterais desses medicamentos, como coágulos sanguíneos).

Em outras palavras, para que a sequência de genes possa ser elegível para proteção patentária, ela deve estabelecer que a reivindicação é sobre uma sequência de genes

\footnotetext{
2.39.2.3 Reivindicações do tipo: g) Uso do produto $X$ caracterizado por ser no tratamento da doença $Y, h$ ) Processo de tratar a doença $Y$ caracterizado pela administração do produto $X$ (ou composição contendo o produto X), não são concedidas por se constituírem em um método terapêutico. Aqui cabe uma observação: caso não se trate de 'tratar a doença $Y$ ', mas, sim, de 'diagnosticar a doença $Y$ ' (ou algum texto semelhante), deve-se considerar o que foi dito acima com relação aos métodos de diagnóstico. 2.39.2.4 Reivindicações do tipo: i) Uso do produto X caracterizado por ser na preparação de um medicamento para tratar a doença $Y, j$ ) Uso do produto X caracterizado por ser na preparação de um medicamento para tratar a doença $Y$, tratamento este que consiste em tal e tal, são as conhecidas como de 'fórmula suiça', e são quase que exclusivamente utilizadas em invenções de segundo uso médico".

${ }_{199}$ BARBOSA, op. cit., p. 29.
} 
"produzida em laboratório", que transmite determinada informação necessária à síntese de uma determinada proteína que irá desempenhar determinada função, com uma determinada finalidade. 


\section{A EXPERIÊNCIA BRASILEIRA E O DIREITO COMPARADO}

Neste Capítulo, que será dividido em 02 grandes blocos, pretende-se discutir os principais aspectos relacionados à evolução do direito patentário no Brasil e no direito comparado (em especial nos EUA e UE), em vista aos novos desenvolvimentos que vêm sendo trazidos pela biotecnologia.

O primeiro bloco tratará dos seguintes aspectos: (a) as origens e evolução do direito patentário no Brasil à luz das inovações biotecnológicas; (b) as tentativas de regulamentação da biotecnologia no Brasil, bem como políticas para implementação de mecanismos de incentivo a tais inovações; (c) as diretrizes do INPI relativas a patentes biotecnológicas e farmacêuticas $^{200}$.

Em seguida, passar-se-á a uma análise similar no direito patentário comparado, tomando-se como referências principais os EUA e a UE, traçando-se um paralelo entre ambos os sistemas pela identificação de similaridades e divergências no reconhecimento de inovações biotecnológicas, em especial no que diz respeito aos possíveis tratamentos conferidos a genes humanos e sua eventual forma de proteção jurídica.

Para tanto, serão realizadas análises a respeito da evolução do tratamento legislativo e jurisprudencial em matéria de biotecnologia em ambos os contextos, permitindo-se um estudo comparativo em relação ao Brasil, a fim de tentar oferecer ideias e alternativas para que se busque atingir a finalidade socioeconômica brasileira objetivada pelo seu sistema de proteção de direitos de propriedade industrial.

\subsection{Direito patentário brasileiro}

Atualmente, o sistema de propriedade industrial brasileiro tem fundamento constitucional e é regulado essencialmente pela Lei de Propriedade Industrial, pela Convenção de Paris (CUP), pelo Acordo sobre Aspectos dos Direitos sobre a Propriedade Intelectual Relacionados ao Comércio (TRIPS), e pelo Tratado de Cooperação em Matéria

\footnotetext{
${ }^{200}$ Muito embora o escopo original desta dissertação tenha considerado a possibilidade de se estudar antecedentes jurisprudenciais administrativos e judiciais, não foi identificado qualquer caso que pudesse ser considerado relevante para o tema de forma direta.
} 
de Patentes $(\mathrm{PCT})^{201}$, além de outras normas legais e infralegais que serão tratadas ao longo deste Capítulo.

Embora a regulamentação vigente e as políticas públicas busquem incentivar e regulamentar a proteção a inovações biotecnológicas no Brasil (como será verificado a seguir), tal assunto ainda é tratado de forma bastante incipiente e continua sendo alvo de importantes divergências, como procuramos demonstrar nos Capítulos anteriores.

Antes de se adentrar à análise e discussão dos aspectos legais relacionados à abordagem brasileira no que se refere ao fomento e proteção dessas inovações biotecnológicas, em especial no que tange aos genes humanos e benefícios decorrentes dos resultados práticos de sua exploração científica nos campos da medicina e saúde pública, importante entender como se deu a evolução do entendimento e objetivos buscados pelas políticas públicas brasileiras.

Para tanto, passa-se em seguida a breve quadro demonstrativo da evolução histórica nacional a respeito da proteção patentária e de que forma se reconhecia tal privilégio, a fim de melhor contextualizar a introdução da discussão principal do presente estudo.

Como será observado a seguir, apenas a partir da década de 1990 surgiu uma preocupação maior com os aspectos relativos à proteção e políticas de incentivos em matéria de biotecnologia no Brasil ${ }^{202}$.

Foi quando diversas normas legais e infralegais vieram a ser propostas e editadas, dentre as quais destacam-se as seguintes: (a) as diretrizes do INPI voltadas à concessão de patentes biotecnológicas e farmacêuticas, bem como atos normativos correlatos, (b) a discussão acerca de projetos de lei que pretenderam criar exceção ao artigo 10, inciso IX, da LPI, para fins de expressamente permitir o patenteamento de material biológico, desde que demonstrados os requisitos de patenteabilidade e ao menos uma utilidade industrial; e (c) políticas de incentivo ao desenvolvimento biotecnológico no país.

\footnotetext{
201 Principais acordos internacionais que envolvem questão da proteção patentária de inovações biotecnológicas que compõem o arcabouço normativo no qual se insere hoje o Brasil (Capítulo 5.2).

${ }^{202}$ Além dos textos legais discutidos nos Capítulos que se seguem, há outros instrumentos normativos relacionados à proteção patentária em âmbito biotecnológico, como a Lei de Cultivares, que deixam de ser tratados aqui por desviarem da linha de análise principal deste estudo.
} 
Esses temas são discutidos mais detalhadamente nos Capítulos 5.1.2, 5.1.4 e 5.1.5, respectivamente.

\subsubsection{Origens e evolução do direito patentário brasileiro}

\subsubsection{Alvará de 1809}

O Alvará de 28 de Abril de 1809 reconheceu, pela primeira vez no Brasil, a possibilidade de concessão de privilégios a inventores e introdutores de novas máquinas.

A importância deste diploma legal reside no fato de que ele já apresenta feições que até hoje prevalecem no âmbito da proteção patentária atual, por apresentar as seguintes características: (a) a exigência do requisito da novidade; (b) a concessão do privilégio de exclusividade por um prazo determinado de 14 anos; e (c) o estabelecimento que a invenção ou utilidade passa a integrar o domínio público após referido prazo de proteção, o que implica dizer também que haverá a obrigação de publicação da invenção ${ }^{203}$.

\subsubsection{Constituição de 1824}

Em 1824, a Constituição Brasileira passou a reconhecer expressamente a importância da proteção aos trabalhos inovadores de seus inventores, assegurando-lhes o "privilégio exclusivo temporário" em nível constitucional, como se pode depreender dos termos de seu artigo 179 , alínea $26^{204}$.

\footnotetext{
${ }^{203}$ Artigo VI, Alvará De 28 de Abril de 1809: “VI. Sendo muito conveniente que os inventores e introductores de alguma nova machina, e invenção nas artes, gozem do privilegio exclusivo além do direito que possam ter ao favor pecuniario, que sou servido estabelecer em beneficio da industria e das artes; ordeno que todas as pessoas que estiverem neste caso apresentem o plano do seu novo invento á Real Junta do Commercio; e que esta, reconhecendo a verdade, e fundamento delle, lhes conceda o privilegio exclusivo por quatorze annos, ficando obrigadas a publical-o depois, para que no fim desse prazo toda a Nação goze do fructo dessa invenção. Ordeno outrosim, que se faça uma exacta revisão dos que se acham actualmente concedidos, fazendo-se publico na forma acima determinada, e revogando-se todos os que por falsa allegação, ou sem bem fundadas razões obtiveram semelhantes concessões."

${ }^{204}$ Conforme artigo 179, alínea XXVI, "Os inventores terão a propriedade das suas descobertas, ou das suas producções. A Lei lhes assegurará um privilegio exclusivo temporario, ou lhes remunerará em resarcimento da perda, que hajam de soffrer pela vulgarisação".
} 


\subsubsection{Lei s/n de 1930}

Já no ano de 1830, a fim de regulamentar o direito constitucional assegurado a partir da entrada em vigor da Constituição de 1824, entrou em vigor a Lei s/n de 28 de Agosto para tratar especificamente de patentes. A lei protegia o descobridor ou inventor, assegurando-lhe "a propriedade e o uso exclusivo da sua descoberta, ou invenção" (conforme seu artigo $1^{\circ}$ ).

Pode-se dizer que se trata da primeira lei de patentes brasileira, segundo a qual se "concede privilégio ao que descobrir, inventar ou melhorar uma indústria útil e um prêmio ao que introduzir uma indústria estrangeira, e regula a concessão". A concessão da patente se daria pelo prazo de 5 a 20 anos, de acordo com a "qualidade da descoberta ou invenção", sendo possível maior prazo concedido por lei.

\subsubsection{Lei 3.129/1882}

O próximo marco também de grande importância ao direito patentário brasileiro se deu por meio da entrada em vigor da Lei 3.129, de 14 de Outubro de 1882, que passou a regulamentar de forma mais detalhada a concessão de patentes, seja ela relativa a autores de invenção ou descoberta industrial.

Para os fins desta lei, a invenção ou descoberta que assegura a sua propriedade e uso exclusivo são aquelas que se referem, nos termos do seu artigo $1^{\circ}$, parágrafo $1^{\circ}$, a invenções de novos produtos industriais, invenção de novos meios ou aplicação nova de meios conhecidos para obtenção de um produto ou resultado industrial, e o melhoramento de invenção já privilegiada (assim considerado como a simplificação de seu modo de fabricação ou uso, ou o aumento de utilidade).

Referido marco legal, além de esclarecer de forma mais específica o que se entende por invenção ou descoberta, bem como o requisito da novidade ${ }^{205}$, previu de modo expresso as matérias não patenteáveis, em seu artigo $1^{\circ}$, parágrafo $2^{\circ}$, quais sejam:

\footnotetext{
${ }^{205}$ Aqui já se considerava o critério da novidade em seu aspecto objetivo, por determinar que tal análise compreendia identificação do estado da técnica "dentro ou fóra do Imperio", conforme artigo $1^{\circ}$ de referida lei.
} 
invenções contrárias à lei ou à moral, ofensivas à segurança pública, nocivas à saúde pública, e aquelas que não produzirem um resultado prático industrial.

Nada obstante, foram também nesta oportunidade inseridos artigos relativos à prioridade internacional, à contrafação e à extinção da patente. O privilégio passou a ser concedido por um prazo de 15 anos.

Logo em seguida, no ano de 1883, o Brasil firmou a primeira edição da CUP na condição de signatário original. À época, a redação original da CUP não usava a terminologia "patente", mas sim os termos "privilégio" e "privilégio de invenção".

Maiores detalhes a respeito da CUP e suas posteriores revisões poderão ser verificados no Capítulo 5.2.2.

\subsubsection{Decreto 16.254/1924}

Por meio do Decreto 16.254, datado de 19 de Dezembro de 1923, houve a criação da Diretoria Geral de Propriedade Industrial (DGPI), encarregada de serviços de patentes e marcas. A DGPI permaneceu como órgão responsável e encarregado por tais serviços até o ano de 1970, quando a Lei 5.648, de 11 de Dezembro de 1970, criou o INPI.

\subsubsection{Decreto 24.507/1934}

Em 29 de Junho de 1934, foi editado o Decreto 24.507/1934, que, dentre outras questões, regulamentava a concessão de patentes de desenho ou modelo industrial. Apesar de trazer inovações importantes, referido texto legal não originou grandes novidades ao tratamento acerca da proteção de patentes no Brasil, pois se prestava a regulamentar em especial a proteção dos desenhos industriais, que eram tratados como patentes.

\subsubsection{Códigos de Propriedade Intelectual de 1945, 1969 e 1971}

No ano de 1945, foi editado o primeiro Código de Propriedade Industrial (DecretoLei $7.903 / 1945)$. De acordo com o artigo $6^{\circ}$ de referido texto legal, "os autores de 
invenção suscetivel de utilização industrial terão o direito de obter patente que lhes garanta a propriedade e o uso exclusivo da mesma invenção".

A invenção, para que tenha sua proteção reconhecida, além de ter sua aplicação industrial reconhecida, deverá ser considerada nova, e portanto: (a) que até a data do depósito do pedido de patente, a invenção não poderá ter sido depositada ou patenteada no país, tampouco usada publicamente ou descrita em publicações de modo que possa ser realizada; e (b) que até um ano antes da data do depósito do pedido de patente no país, a invenção não tenha sido patenteada no estrangeiro, nem descrita em publicações de modo que possa ser realizada.

E aqui já é possível identificar aspectos importantes relacionados ao objeto do presente estudo: medicamentos e produtos alimentícios, bem como matérias ou substâncias obtidas por meios ou processos químicos estavam expressamente incluídos entre as matérias não patenteáveis (artigo $8^{\circ}$, números $2^{\circ}$ e $3^{\circ}$ ). De outro lado, contudo, os processos para sua obtenção são por tal diploma legal considerados patenteáveis.

O Código de Propriedade Intelectual de 1945 também instituiu mecanismos de licenciamento obrigatório e de desapropriação das patentes. O prazo do privilégio de exclusividade para invenções era de 15 anos, enquanto o prazo estabelecido para modelos de utilidade foi de 5 anos.

Em 1969, foi editado um novo Código de Propriedade Industrial (por meio do Decreto-Lei 1.005, de 21 de Outubro de 1969). Este Código, contudo, em pouco inovou no que diz respeito ao regramento para proteção patentária, cabendo apenas mencionar a regra de exclusão prevista no artigo $8^{\circ}$, que prevê expressamente - dentre outros - o seguinte:

(a) as substâncias, matérias ou produtos obtidos por meios ou processos químicos, ressalvando-se, porém, a privilegiabilidade dos respectivos processos de obtenção ou modificação;

(b) as substâncias, matérias, misturas ou produtos alimentícios, químicofarmacêuticos e medicamentos, de qualquer espécie, bem como os respectivos processos de obtenção ou modificação; 
(c) as misturas e ligas metálicas em geral, ressalvando-se, porém, as que, não compreendidas na alínea anterior, apresentarem qualidades intrínsecas específicas, precisamente caracterizadas pela sua composição qualitativa, definida quantitativamente, ou por tratamento especial a que tenham sido submetidas;

(d) as justaposições de processos, meios ou órgãos conhecidos, a simples mudança de forma, proporções, dimensões ou de materiais, salvo se daí resultar, no conjunto, um efeito técnico novo ou diferente, não compreendido nas proibições das alíneas anteriores, ou em caso de invenções que constituam objetos que se prestem a trabalho ou uso prático e tragam à função a que se destinam melhor utilização;

(e) os usos ou empregos relacionados com descobertas, inclusive de variedades ou espécies de microrganismos, para fim determinado; e

(f) as técnicas operatórias ou cirúrgicas ou de terapêutica não incluídos os dispositivos, aparelhos ou máquinas.

São situações que tangenciam a questão da discussão acerca da conceituação de invenções e descobertas, estas últimas, por englobar processos e fenômenos da natureza, expressamente excluídas do sistema de proteção patentária. Esta é uma discussão bastante presente durante toda a evolução jurisprudencial americana, em razão do requisito da utilidade (usefulness), elemento cuja apreciação é controversa no âmbito brasileiro, muito embora doutrinas brasileiras de renome considerem que esse aspecto deveria ser, sim, analisado $^{206}$.

Seguiu-se a este um novo Código de Propriedade Industrial logo no ano de 1971: a Lei 5.772, de 21 de Dezembro de 1971, que trouxe novidades relevantes para o âmbito do presente estudo e somente veio a ser revogado na década de 1990 pela LPI.

Este novo Código de Propriedade Industrial ampliou as restrições anteriormente previstas, estabelecendo que fariam parte do rol das matérias não passíveis de

\footnotetext{
${ }^{206}$ Este assunto é discutido detalhadamente no Capítulo 3.5.3.
} 
patenteamento "as substâncias, matérias, misturas, elementos ou produtos de qualquer espécie, bem como a modificação de suas propriedades fisico-químicas e seus respectivos processos de obtenção ou modificação, quando resultantes de transformação do núcleo atômico",207. $^{\text {, }}$.

O prazo de duração da patente de invenção se daria no âmbito desta lei por um período de 15 anos, enquanto o do modelo de utilidade passaria a ser de 10 anos.

\subsubsection{Lei 9.279/1996 (Lei de Propriedade Industrial)}

Foi apenas em 14 de maio de 1996 que a nova e atual LPI entrou em vigor. Este texto normativo atualiza a legislação brasileira no que tange à proteção de direitos de propriedade industrial, trazendo como uma das principais evoluções, sob o ponto de vista das inovações biotecnológicas, reduções das limitações impostas pelos diplomas legais anteriores. A este respeito, importa ressaltar que foi levantada a proibição relativa ao patenteamento de medicamentos, além da instituição das patentes de pipeline ${ }^{208}$.

Referido diploma legal incorporou muitas das normas previstas no TRIPS, que já havia sido incorporado ao ordenamento jurídico pátrio por meio do Decreto ${ }^{\circ} 1.355 / 1994$ - muito embora ele tenha adquirido aplicabilidade interna apenas a partir de $2000^{209}$.

Ainda, as patentes de invenção passam, a partir da entrada em vigor da nova Lei de Propriedade Industrial, a ter validade de 20 anos, enquanto as de modelos de utilidade, prazo de 15 anos, o que denota evidente maior ênfase e importância na proteção das inovações tecnológicas, em virtude do aumento na outorga da proteção ${ }^{210}$.

Mas a grande inovação trazida pela LPI no que tange às invenções biotecnológicas pode ser verificada no seu artigo 10, incisos VIII e IX, no artigo 18, inciso III, e no artigo 24. É a partir deste ponto que o ordenamento jurídico nacional passa a explorar de forma

\footnotetext{
${ }^{207}$ Conforme artigo 9, alínea “j”, da Lei 5.772/71.

${ }^{208}$ Lei 10.196/2001, que altera a LPI e insere novas disposições relativas às patentes pipeline e determina a necessidade de aprovação da ANVISA para o caso de concessão de patentes para produtos e processos farmacêuticos, conforme discutido no Capítulo 3.6.2.

${ }^{209}$ Para maiores detalhes a respeito do TRIPS, vide o Capítulo 5.2.3.

${ }^{210}$ Situação esta que se coaduna com as disposições do TRIPS, que determinou aos países signatários garantirem uma proteção patentária por, no mínimo, 20 anos.
} 
mais específica a questão da proteção patentária que se insere no âmbito do presente estudo.

Muito embora a lei brasileira pró́ba o patenteamento de seres vivos naturais e materiais biológicos na natureza (ainda que dela isolados), tal regra foi excepcionada pela permissão de se patentear microrganismos que atendam aos requisitos de patenteabilidade, por considerá-los compostos químicos. Justamente por conta de tal entendimento é que se mostra possível que invenções originadas da engenharia genética podem estar amparadas pela proteção.

\subsubsection{CGEN}

A Medida Provisória n ${ }^{\circ}$ 2.186-16/2001 teve por principal finalidade a definição do que é patrimônio genético e como seu acesso se daria no Brasil; nada obstante, previu a criação do Conselho de Gestão do Patrimônio Genético (CGEN), órgão vinculado ao Ministério do Meio Ambiente, relativo ao acesso ao patrimônio genético e conhecimento tradicional associado.

Referido texto legal veio a ser regulamentado no mesmo ano, por meio do Decreto 3.945/2001, que efetivamente cria o CGEN e estabelece que o Contrato de Utilização do Patrimônio Genético e de Repartição de Benefícios deve anteceder o depósito do pedido de patente.

O requerente da patente sobre processo ou produto obtido a partir de amostra de componente do patrimônio genético deve informar a origem do material genético e do conhecimento associado.

De acordo com a Resolução CGEN 23/2006, o requerente deve declarar ao INPI que cumpriu as determinações, bem como informar o número e a data da Autorização de Acesso correspondente. 
Posteriormente, nova regulamentação veio por meio do Decreto $n^{0} 5.459 / 2005$, que estabelece a suspensão e o cancelamento da patente (art. 10, VIII e IX) como possíveis sanções às infrações administrativas contra o patrimônio genético.

Segundo tal diploma normativo, o acesso a recursos genéticos por instituições estrangeiras só pode ocorrer caso estas estejam associadas a uma instituição nacional (seja de propósito econômico ou estritamente científico). Se a solicitação envolver tanto recursos genéticos quanto CTA, o CGEN é o único que pode autorizá-la - salienta-se, contudo, que o ICMBio é o órgão competente para autorizar a coleta de recursos genéticos.

Nesse ponto, a legislação brasileira muitas vezes dificulta o acesso, levando a resultado oposto ao desejado. Em primeiro lugar, pelo fato de que o processo de autorização do CGEN é bastante lento e rigoroso, sendo certo que nos últimos 10 anos, apenas 1 em cada 3 pedidos foi atendido ${ }^{211}$. Ao lado disso, devem-se também levar em consideração as pesadas penalidades impostas aos pesquisadores nacionais, no caso de descumprimento das regulamentações do CGEN, sem que existam medidas efetivas no sentido de monitorar e limitar o contrabando por estrangeiros.

Há, de forma geral, dificuldade no processo e incerteza jurídica envolvida, havendo uma crescente participação do Judiciário em decisões relativas ao patenteamento em biotecnologias e/ou acesso a patrimônio genético local. Uma das medidas para minimizar as dificuldades foi uma norma do Ministério do Meio Ambiente, editada em 2011, que viabiliza a regularização do acesso a recursos genéticos, inclusive nos casos em que já tenha havido o acesso sem a devida autorização.

\subsubsection{Lei 11.105/2005 (Lei de Biossegurança)}

A Lei 11.105/2005, de 24 de Março de 2005, foi responsável pela criação do Conselho Nacional de Biossegurança (CNBS) e pela reestruturação da Comissão Técnica Nacional de Biossegurança (CTNBio), que tem o objetivo de acompanhar o desenvolvimento científico nas áreas de biossegurança, biotecnologia, bioética e afins, dispondo também sobre Política Nacional de Biossegurança (PNB).

\footnotetext{
${ }^{211}$ Informação extraída do artigo "Leis antiquadas travam avanço da bioeconomia", publicado no Jornal Estado de São Paulo, Caderno de Economia, B-7, em 19 de outubro de 2014.
} 
A Lei de Biossegurança veio a ser regulamentada pelo Decreto 5.591/2005, documento este que determina que o patenteamento de tecnologias genéticas de restrição do uso é uma infração administrativa (conforme seu artigo 69, inciso XVII). A este respeito, assevera DINIZ que:

“Pela Lei 11.105/2005 está proibido o patenteamento de tecnologias genéticas de restrição de uso, ou seja, de qualquer processo de intervenção humana para geração ou multiplicação de plantas geneticamente modificadas para produzir estruturas reprodutivas estéreis, bem como qualquer forma de manipulação genética que vise a ativação ou desativação de genes relacionados à fertilidade das plantas por indutores químicos externos (art. 60, VII e parágrafo único)."212

Esta lei se aplica ao segmento da engenharia genética destinada à manipulação de organismos vivos, ou seja, à pesquisa e comercialização de OGMs. A Lei 8.974/1995 (revogada) já tratava da questão de biossegurança de organismos geneticamente modificados, embora não tenha estabelecido um processo normativo adequado, gerando inúmeros impasses.

Dentre os principais aspectos relacionados à Lei de Biossegurança, destacam-se referências à proibição do patenteamento das tecnologias, caso não estejam em conformidade com as regras legais ali $\operatorname{previstas}^{213}$ : (a) organismos, DNA, RNA, moléculas de RNA/DNA recombinante, engenharia genética, organismos geneticamente modificados e derivativos, célula germinal humana, clonagem, inclusive para fins reprodutivos e terapêutica, e células-tronco embrionárias; (b) casos em que se permite a utilização de células-tronco embrionárias obtidas de embriões humanos, para fins de pesquisa e terapia; (c) definição de atividades de pesquisa proibidas em relação a organismos geneticamente modificados.

Muito embora inegável a importância de referida regulamentação e sua direta relação com o desenvolvimento da biotecnologia, especialmente no que diz respeito à engenharia genética (o que justifica esta breve referência), nenhum desses aspectos se relaciona diretamente ao âmbito do estudo ora proposto - que não envolve

${ }^{212}$ DINIZ, op. cit., p. 492.

${ }^{213}$ A este respeito, vide artigo $6^{\circ}$, incisos II, III, IV e VII da Lei de Biossegurança. 
primordialmente o estudo de OGMs, uma vez que estes possuem âmbito de análise distinta, até porque implicam necessariamente uma intervenção humana de caráter marcadamente modificativo que por si só exclui a discussão invenção $x$ descoberta que marca a análise sobre a patenteabilidade dos genes.

\subsubsection{Diretrizes do INPI}

O primeiro documento a ser analisado é o que define as diretrizes para exames de patentes publicado pelo INPI em 2002, por meio do qual foram estabelecidas as premissas básicas consideradas por este órgão para a análise e concessão de patentes em geral.

Dentre referidos aspectos gerais, importante destacar o item 1.4, que trata da questão do exame substantivo preliminar, que se mostra de suma importância para o caso das patentes biotecnológicas (tanto é assim que precederia até mesmo a busca de anterioridades).

Sob este aspecto, uma reivindicação de patente pode ser preliminarmente rejeitada caso: (a) haja insuficiência descritiva; (item 1.5.1); (b) as reivindicações incidirem em proibição legal (item 1.5.2); (c) não seja apresentada aplicação industrial para a invenção reivindicada (item 1.5.3); (d) provas apresentadas por intermédio de petição de subsídios indubitavelmente comprovam falta de novidade ou nível inventivo de todas as reivindicações, dispensando a realização de busca complementar (vide itens 1.4.5 e 1.7); (e) o certificado de adição não tiver o mesmo conceito inventivo do pedido ou patente principal, será dada oportunidade ao depositante para manifestar-se a respeito, o qual poderá requisitar a transformação do certificado de adição em pedido de patente."214

Quanto à patenteabilidade de reivindicações que incidam em proibição legal relacionadas a materiais e processos biológicos, o examinador deve verificar e analisar o pedido e emitir parecer negativo conforme previsão do artigo 10, inciso IX, da LPI (bem como quanto às exceções às restrições de referido dispositivo legal), e, ainda, às proibições do artigo 18, da LPI.

214 INPI. Diretrizes de Exame de Patentes, dezembro de 2002. Disponível em: http://www.inpi.gov.br/images/stories/Diretrizes doc 20 de dez verso final 26 dez.pdf. Acesso em: 28/10/2014. 
Em seguida, o requerente deve apresentar relatório descritivo, desenhos e reivindicações, a fim de delimitar a matéria de que trata o pedido, a área de aplicação e o estado da técnica considerado, além de um ou mais exemplos de execução, eventualmente descritos com base em desenhos. A exigência aqui estabelecida tem por objetivo revelar a finalidade e o escopo da proteção ${ }^{215}$.

A Divisão de Química Orgânica, Biotecnologia e Áreas Correlatas do INPI também editou diretrizes ${ }^{216}$ para fins de análise e concessão de patentes biotecnológicas e farmacêuticas, à luz de seu entendimento acerca da legislação brasileira vigente.

O item 2.3.2 de referidas diretrizes revela o entendimento do INPI no que diz respeito à natureza dos genes para fins de avaliação das reivindicações de patente, e possibilita de modo expresso o depósito de patente de produto no caso de cadeias polinucleotídicas sintéticas, por serem compostos químicos, sendo a reivindicação feita pela caracterização da sequência dos nucleotídeos da cadeia.

Já o item 2.3.3 estabelece que não são passíveis de proteção patentária, por não carecerem de clareza e precisão do relatório descritivo (conforme determina o artigo 25, da Lei de Propriedade Intelectual), reivindicações de: (a) sequências de DNA caracterizadas por codificarem uma determinada proteína, e por codificarem um polipeptídio com a sequência de aminoácidos de determinada proteína $^{217}$; (b) proteínas caracterizadas por apresentarem uma determinada atividade, apresentarem uma determinada composição percentual de aminoácidos; e (c) plasmídeos caracterizados por uma designação do próprio inventor.

\footnotetext{
${ }^{215}$ No caso das biotecnologias, não sendo possível a descrição do produto envolvido na patente, deve ser encaminhada uma amostra desse material para depósito, nos termos do artigo 24, parágrafo único, da LPI. As exigências exclusivas para as patentes em biotecnologia encontram-se no item 16, do Ato Normativo INPI $127 / 1997$.

${ }^{216}$ Segundo informações contidas em seu site oficial, conforme consulta realizada em Jul./2013 - atualmente se encontram em processo de revisão.

217 “a. Seqüência de DNA caracterizada por codificar a proteina X; b. Seqüência de DNA caracterizada por codificar um polipeptídeo apresentando a seqüencia de aminoácidos da proteína X' (Vide: http://www.inpi.gov.br/images/stories/Diretrizes_Farmaceutica_e_Biotec.pdf).
} 
Reconhecendo e ressaltando a diferença entre "invenção" e "descoberta", no item 2.4 das diretrizes, o INPI esclarece que mesmo se tratando de extratos isolados ${ }^{218}$ ou compostos químicos obtidos sinteticamente ${ }^{219}$, caso os primeiros sejam tão-somente isolados da natureza e os segundos possuam correspondentes de ocorrência natural, não podem ser considerados como invenção de acordo com o disposto no artigo 10, incisos I (para compostos não biológicos) e IX (para compostos biológicos e extratos isolados da natureza), da LPI.

Essa proibição encontra guarida na possibilidade aberta pelo artigo 27(2) e (3) do TRIPS, que ao versar sobre matéria patenteável estabelece que:

“2. Os Membros podem considerar como não patenteáveis invenções cuja exploração em seu território seja necessário evitar para proteger a ordem pública ou a moralidade, inclusive para proteger a vida ou a saúde humana, animal ou vegetal ou para evitar sérios prejuízos ao meio ambiente, desde que esta determinação não seja feita apenas por que a exploração é proibida por sua legislação.

3. Os Membros também podem considerar como não patenteáveis:

a) métodos diagnósticos, terapêuticos e cirúrgicos para o tratamento de seres humanos ou de animais;

b) plantas e animais, exceto microorganismos e processos essencialmente biológicos para a produção de plantas ou animais, excetuando-se os processos não-biológicos e microbiológicos. Não obstante, os Membros concederão proteção a variedades vegetais, seja por meio de patentes, seja por meio de um sistema sui generis eficaz, seja por uma combinação de ambos. $O$ disposto neste subparágrafo será revisto quatro anos após a entrada em vigor do Acordo Constitutivo da OMC”.

\footnotetext{
218 "2.4.2 Extratos compreendem, salvo em casos muito raros, vários compostos entre ativos e não ativos, mesmo assim, uma vez que tão-somente isolados da natureza, são considerados como não invenção pelo Art. 10 (IX)." (INPI. Divisão de Química Orgânica Biotecnologia e Áreas Correlatas. Diretrizes para o Exame de Pedidos de Patente nas Áreas de Biotecnologia e Farmacêutica Depositados Após 31/12/1994, 2003).

219 "2.4.3 Compostos químicos obtidos sinteticamente que possuam correspondentes de ocorrência natural, não havendo como distingui-los destes, não são considerados como invenção de acordo com o disposto no Art. 10 (I) - se forem não biológicos - ou (IX) - se forem biológicos.” (Idem)
} 
A opção do legislador brasileiro que foi adotada exclui expressamente os materiais biológicos naturais, mesmo que isolados de seu meio natural, situação esta que não parece ser a mais acertada à luz do quanto foi discutido, acima - muito embora possa, em princípio, permitir uma construção capaz de tutelar ao menos os cDNAs que se revista dos requisitos discutidos no Capítulo 3.5. Contudo, uma reforma legislativa que admita tal hipótese estaria amparada pelo TRIPS, conforme acima apresentado.

De acordo com o item 2.6, por sua vez, tem-se que uma reivindicação de composição caracterizada por apenas um produto, sendo este não-patenteável, não poderia ser concedida - pois a proteção à composição, nesse caso, conferiria também proteção ao produto. Essa impossibilidade se estende às situações em que os demais componentes são uma mera diluição (porquanto o solvente não contribui para o propósito final da composição).

As composições definidas por sua forma de aplicação não são precisas, por não definirem rigorosamente a matéria protegida, e portanto devem ser rejeitadas nos termos do item 2.7 das diretrizes do INPI. Caso possuam algum tipo de relação com a área médica, essas composições também se enquadrariam nos métodos terapêuticos - e, portanto, sujeitos aos termos do artigo 10, inciso VIII, da LPI ${ }^{220}$.

Quanto aos animais, plantas e suas partes, naturais ou isolados, o item 2.12 confirma o entendimento de que não poderão ser considerados invenções; quando resultarem de manipulação pelo homem, não são patenteáveis por força do artigo 18, inciso III, da LPI.

O item 2.26 das diretrizes trata de um dos assuntos mais controversos e discutidos em todos os principais países no que diz respeito à proteção de patentes biotecnológicas, em especial ao patenteamento de genes: os processos de extração/isolamento. Segundo o INPI, há necessidade de definição (item 2.21): (a) do material de partida, do produto obtido e do meio de transformação; (b) das etapas necessárias para se atingir o objetivo proposto; (c) material a ser usado e objetivo do uso (no caso de "uso").

\footnotetext{
${ }^{220}$ De acordo com referido dispositivo legal, "técnicas e métodos operatórios ou cirúrgicos, bem como métodos terapêuticos ou de diagnóstico, para aplicação no corpo humano ou animal" não podem ser consideradas invenções ou modelos de utilidade.
} 
Os processos de modificação genética de microrganismos estão sujeitos às mesmas observações aplicáveis aos demais processos, inclusive os de extração/isolamento acima mencionados (item 2.27); já os processos biológicos naturais, por sua vez, não podem ser consideradas invenções (item 2.28).

Relativamente aos métodos que envolvem processos biotecnológicos terapêuticos e diagnósticos, importante se faz trazer à discussão os termos dos itens 2.36 e 2.37 das diretrizes ora em análise.

Os métodos de tratamento do corpo humano ou animal podem ser terapêuticos (ou seja, implicam cura e/ou prevenção de uma doença ou mau funcionamento do corpo, ou mesmo alívio de sintomas, visando a restabelecer ou manter suas condições de saúde), ou não-terapêuticos (aqueles que têm como ponto de partida as condições de saúde do ser, e não objetivam qualquer profilaxia ou cura de doenças, tampouco o alívio de sintomas de dor ou desconforto).

Métodos terapêuticos não são invenções, a teor do quanto dispõe o artigo 10, inciso VIII, da LPI. Entretanto, os métodos não terapêuticos são considerados patenteáveis desde que apresentem caráter técnico, não sejam essencialmente biológicos (processos biológicos naturais) e não sejam de uso exclusivamente individual. Portanto, as reivindicações devem estar limitadas a métodos não terapêuticos.

Quanto aos métodos diagnósticos, o item 2.37 entende se tratarem daqueles que diretamente concluem sobre o estado de saúde do paciente, como resultado da técnica utilizada. Da mesma forma, os métodos diagnósticos não são patenteáveis no Brasil, tendo em vista o mesmo dispositivo legal acima indicado.

Os métodos de diagnóstico são constituídos por 3 etapas distintas: (a) a primeira, que se refere ao exame do paciente; (b) a segunda, que envolve a realização de testes clínicos no paciente; e (c) por fim, a comparação dos dados obtidos nos testes com valores normais (fase médica dedutiva). 
Contudo, não estando presente a última etapa, não se pode falar em método diagnóstico, mas sim em simples método de levantamento de dados (uma vez que neste caso não se conclui o estado de saúde do paciente). Portanto, os métodos de obtenção de informações via de regra podem ser considerados patenteáveis, desde que representem um resultado intermediário que, por si só, não é suficiente para uma decisão quanto ao tratamento adequado.

A respeito de referidas diretrizes, a Associação Brasileira de Propriedade Intelectual (ABPI) editou e apresentou ao INPI a Resolução 52/2003, contendo propostas de alterações à redação de alguns itens para os casos por eles tratados, dentre os quais importa destacar os seguintes:

(a) Entende a ABPI que poderia haver controvérsia na interpretação de reivindicações de métodos de diagnósticos conclusivos e não conclusivos com relação ao item 2.37.3 ${ }^{221}$ das Diretrizes para exame de pedidos de patente nas áreas de biotecnologia e farmácia, pois não está claramente definida no referido item a diferença entre tais métodos.

(b) O INPI já vem aceitando reivindicações de material químico-biológico isolado da natureza cuja novidade reside em grau de pureza e/ou aspectos morfofuncionais diferenciados, além do que o TRIPS não prevê qualquer restrição de patenteabilidade de material isolado da natureza, excetuando aqueles que não preenchem os requisitos de patenteabilidade. Por esse motivo, a ABPI sugere a inclusão de um novo subitem nas Diretrizes para o reconhecimento de patentes para material químico-biológico isolado da natureza, cuja novidade e a atividade inventiva residem em grau de pureza e/ou aspectos morfofuncionais diferenciados.

(c) A novidade e a atividade inventiva de uma sequência genética já conhecida pode estar no ato de sua inserção em um novo conjunto de sequências genéticas, de modo que um novo subitem deveria ser acrescentado nas Diretrizes para o reconhecimento de

\footnotetext{
${ }^{221}$ Em geral, métodos de obtenção de informações do corpo humano ou animal são patenteáveis, desde que os dados coletados representem meramente um resultado intermediário que por si só não são suficientes para uma decisão quanto ao tratamento adequado.
} 
patentes para sequências genéticas já conhecidas, porém inseridas em um novo conjunto de sequências genéticas.

Em dezembro de 2012, o INPI abriu a Consulta Pública $n^{\circ}$ 004/2012, com o intuito de discutir diretrizes de exame de pedidos de patente na área de biotecnologia. Os interessados tiveram um prazo de 60 dias para enviar suas sugestões.

Analisando o conteúdo das diretrizes, verifica-se que muitas das recomendações da ABPI não foram adotadas, eis que as novas diretrizes colocadas em discussão apontam para o não reconhecimento da patenteabilidade de produtos biológicos nos seguintes termos:

\section{“4.2.1.1 Produtos biológicos}

O todo ou parte de materiais biológicos, ainda que isolados, ou produzidos de forma sintética que possuam correspondentes de ocorrência natural, não havendo como distingui-los, não serão considerados como invenção, de acordo com o art. 10 (IX) da LPI.

Cabe ressaltar que não é permitida a inclusão de uma limitação negativa (disclaimer) com o termo "não natural", uma vez que não superaria por si só a objeção quanto ao art. 10 (IX) da LPI. (...)

\subsection{Extratos}

Extratos são materiais biológicos isolados da natureza e, portanto, não são considerados invenção com base no art. 10 (IX). Assim, para composições contendo extratos, valem as mesmas considerações apontadas acima para os produtos naturais. (...)

\subsection{Extratos enriquecidos}

Extratos diferenciados de seu correspondente natural por estarem enriquecidos em algum(s) de seus componentes, somente serão passíveis de proteção quando apresentarem características não alcançáveis normalmente pela espécie e que sejam decorrentes de intervenção humana direta. (...) 
$O$ art. 10 (IX) da LPI aplica-se a reivindicações da categoria "produto”, não sendo considerada invenção o todo ou parte de seres vivos naturais e materiais biológicos encontrados na natureza, inclusive o genoma ou germoplasma de qualquer ser vivo natural. Para reivindicações da categoria “processo", como processos, métodos, usos, aplicações, entre outros, o art. 10 (IX) da LPI referese unicamente a processos biológicos naturais, dispondo que esses não são considerados invenção. Quando o processo reivindicado envolve todo ou parte de seres vivos naturais e materiais biológicos encontrados na natureza, inclusive o genoma ou germoplasma, mas não consiste em um processo biológico natural, não há nenhum impedimento para a sua patenteabilidade frente ao que é disposto pelo art. 10 (IX) da LPI. Dessa forma, o uso de um produto natural com um propósito novo, que tenha atividade inventiva e aplicação industrial, representa o resultado de uma intervenção inventiva humana e pode ser patenteado."

Já quanto ao requisito da novidade nas sequências de DNA, assunto que foi tratado já de forma detalhada nos Capítulos 3.5.1 e 3.5.4, as novas diretrizes que estão sob análise sugerem:

"O requisito de novidade, quando relacionado a sequências biológicas, segue o mesmo princípio geral, ou seja, para que uma sequência de aminoácidos ou de nucleotídeos não seja nova frente ao estado da técnica, todos os aminoácidos ou nucleotideos devem ser exatamente os mesmos e estar na mesma ordem da sequência conhecida na técnica. (...)

6.3.1.1 Modificação de sequência(s) por substituições, inserções ou deleções de nucleotídeos não-modificados

De forma geral, modificações de sequências biológicas naturais através da inserção de nucleotídeos não modificados na sequência (no meio ou nas extremidades) é considerada suficiente para adequação ao art. 10 (IX), desde que a sequência resultante formada também não seja de ocorrência natural. Caso a deleção de nucleotídeos ocorra no meio da sequência pleiteada, tal modificação é, a princípio, suficiente para diferenciá-la da molécula natural. Entretanto, caso o(s) nucleotideo(s) deletado(s) esteja(m) na extremidade da sequência, a modificação não é suficiente para adequação ao art. 10 (IX), uma vez que a sequência resultante continua sendo idêntica a parte da sequência natural (vide item 6.3.2). 
Em relação à substituição de nucleotídeos por outros nucleotídeos não modificados, considera-se que tal modificação é suficiente para fins de adequação ao art. 10 (IX), desde que não exista qualquer descrição de sequências naturais (por ex., em espécies relacionadas) contendo tal substituição”.

Quanto aos cDNAs, e seguindo o mais recente entendimento jurisprudencial americano, as diretrizes entendem que poderia estar superada a discussão invenção $x$ descoberta em se tratando de sequência que apresente somente éxons e, portanto, sua patenteabilidade poderia ser avaliada com base nos requisitos legais autorizadores da patente. A este respeito, veja-se item 6.3.6 das diretrizes em discussão:

“6.3.6 cDNA

Moléculas de cDNA representam sequências produzidas a partir de RNAs. No caso de cDNAs oriundos de RNA mensageiros (mRNA), se o gene proveniente possui introns, o cDNA será diferente do gene que codificou esse mRNA, uma vez que a sequência do cDNA apresentará somente a sequência dos exons. Dessa forma, nesses casos, não se pode considerar que uma molécula de cDNA seja igual a uma molécula natural, e sua patenteabilidade deverá ser avaliada com base nos requisitos de novidade, atividade inventiva e aplicação industrial.

Quando o cDNA se tratar de moléculas produzidas a partir de mRNAs de genes que não possuem introns, o dito cDNA terá constituição igual à fita de $D N A / g$ ene que serviu de molde para a sintese desse mRNA. Assim, nesses casos, o cDNA não é considerado invenção, com base no art. 10 (IX) da LPI.

Nos casos de cDNA obtido a partir de outros tipos de RNA (como por exemplo, tRNA, snRNA, rRNA), devem ser verificados se são idênticos ao DNA natural, situação esta em que não seriam considerados invenção art.10 (IX).

Além disso, o simples sequenciamento do cDNA sem a associação de uma função para o mesmo não é suficiente para garantir a aplicação industrial e fundamentação da matéria, estando em desacordo com os arts. 15 e 25 da LPI, respectivamente. 
Acertadamente, as diretrizes em discussão também rejeitam de plano o patenteamento das ESTs. Entretanto, compartilhamos apenas em parte da justificativa para tanto, uma vez que carece aplicação industrial - especialmente se considerado em seu aspecto mais amplo, qual seja, a "utilidade". Segue apreciação sugerida ao tema, a ser possivelmente adotado nas próximas revisões do INPI:

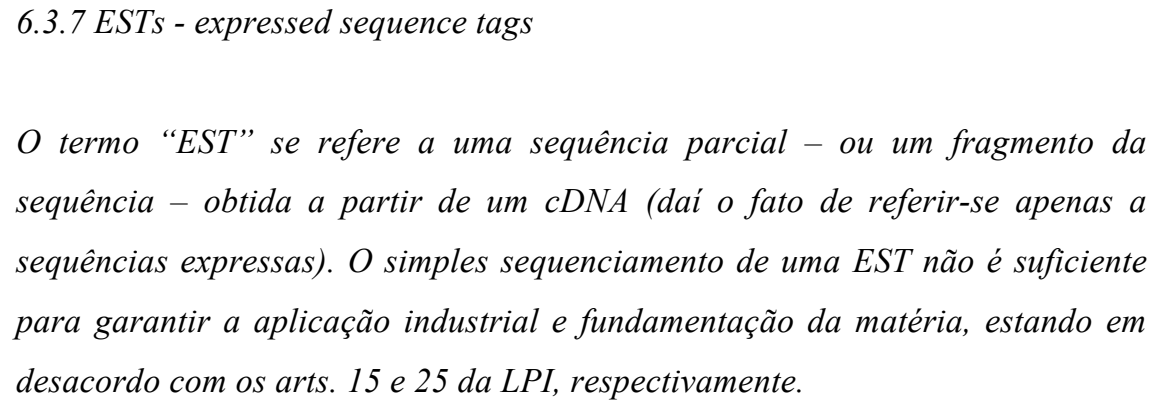

Por outro lado, quando se trata de sequências provenientes de genes que não possuem introns, qualquer EST é considerada um fragmento de uma sequência biológica natural (vide também item 6.3.2)".

Pelo que se pode depreender das propostas apresentadas, esta possível nova interpretação do INPI pode conferir importantes avanços à análise de patentes que envolvam a proteção de genes humanos. Entretanto, há ainda aspectos que devem ainda ser mais profundamente discutidos e avaliados.

\subsubsection{Normas Complementares editadas pelo INPI}

Além das diretrizes editadas para regulamentar a concessão de patentes, inclusive aquelas relativas às invenções biotecnológicas, o INPI editou diversos atos normativos que regulamentam a matéria. 
O Ato Normativo INPI 127/1997 foi o primeiro deles a ser editado. Referido instrumento normativo estabelece, em seu item 16, disposições específicas da área de biotecnologia - em especial no que tange ao depósito de material biológico.

Segundo tal ato normativo, o depósito de material biológico deve ser feito em instituições localizadas no Brasil devidamente autorizadas pelo INPI, ou, na inexistência delas e de instituição indicada em acordo internacional vigente, o depósito pode ser efetuado em qualquer autoridade de depósito internacional reconhecida pelo Tratado de Budapeste sobre o Reconhecimento Internacional do Depósito dos Microrganismos para fins de Instauração de Processos em Matéria de Patentes.

Nada obstante, o Ato Normativo INPI 127/1997 estabelece de forma expressa que o relatório descritivo do pedido de proteção de patente biotecnológica deve conter, além das especificações gerais, as propriedades imprescindíveis da matéria viva, complementarmente à sua descrição.

Já o item 16.3 versa sobre a listagem de sequências biológicas. Os pedidos de patente que descrevam uma sequência de nucleotídeos ou aminoácidos devem conter a listagem de sequências, além do relatório descritivo, reivindicações, desenho e resumo. A listagem deve conter informações gerais quanto ao pedido de patente, quanto à sequência e todas as sequências, ou parte de sequências, descritas no pedido, marcadas por um número identificador.

A descrição das sequências, por sua vez, deve considerar a seguinte metodologia: (a) uma sequência de nucleotídeos é uma sequência de 10 ou mais nucleotídeos (item 16.3.4.1); e (b) uma sequência de aminoácidos é uma sequência de 4 ou mais aminoácidos (item 16.3.4.2). A parte não codificadora (incluindo íntrons) deve ser listada em grupos de 10 bases e a parte codificadora, em grupos de 3 bases (códons).

Este assunto foi posteriormente melhor regulamentado pela Resolução INPI 228/2009, que estabeleceu um procedimento para a apresentação de "Listagem de Sequências" para complementação do relatório descritivo, bem como regras para a representação das sequências de nucleotídeos nela contidas. 
Para esta finalidade, o mencionado ato normativo prevê em seu artigo $2^{\circ}$ que as sequências de nucleotídeos e/ou aminoácidos, fundamentais para a descrição da invenção e que estejam contidas no objeto do pedido de patente, devem ser representadas em uma "Listagem de Sequências", para aferição de suficiência descritiva, em observância ao disposto no artigo 24, da $\mathrm{LPI}^{222}$.

Essa "Listagem de Sequências" deve ser apresentada ao INPI como instrumento complementar ao relatório descritivo, no formato de arquivo eletrônico (a teor do que dispõe seu artigo $3^{\circ}$ ), seguindo o padrão OMPI ST.25 (de acordo com as regras do anexo à Resolução - Anexo: Regras para Apresentação e Representação de Sequências de Aminoácidos e de Nucleotídeos (artigo $4^{\circ}$ ).

Foi expedida pelo INPI também nesse ano a Resolução INPI 207/2009, que disciplina os procedimentos relativos ao requerimento de pedidos de patentes de invenção cujo objeto tenha sido obtido em decorrência de acesso a amostra de componente do patrimônio genético nacional.

Em seguida, veio a Resolução INPI 283/2012, que versa sobre o exame prioritário de pedidos de Patentes Verdes, ou seja, aquelas patentes com foco em tecnologias ambientalmente amigáveis ou tecnologias verdes - que são dispostas e apresentadas em inventário publicado pela OMPI. Em que pese a sua importância, tal resolução é irrelevante para os propósitos do presente estudo e será desconsiderada.

Também no ano de 2012 foi publicada a Resolução INPI 286/2012, que regulamenta o formato de apresentação das sequências biológicas. Em seu artigo $16, \S 3^{\circ}$, tal resolução estabelece que os responsáveis por pedidos depositados antes de 8 de fevereiro de 2010, e que se refiram a sequências biológicas, podem apresentá-las no padrão da "Listagem de Sequências" em formato eletrônico (de acordo com Resolução INPI 228/2009), por intermédio de formulário no modelo de Opinião Preliminar sobre a Patenteabilidade (modelo 1.14, Anexo I, Resolução 286/2012), para que se permita a realização de busca mais completa.

\footnotetext{
${ }^{222}$ Resolução INPI 228/2009, artigo 20: "O requerente de pedido de patente que contenha em seu objeto uma ou mais sequências de nucleotídeos elou de aminoácidos, que sejam fundamentais para a descrição da invenção, deverá representá-las em uma 'Listagem de Sequências', com vistas à aferição da suficiência descritiva do pedido de patente, de que trata o art. 24, da Leu 9.279, de 14 de maio de 1996".
} 


\subsubsection{Propostas de Modificações na Lei de Propriedade Intelectual em Biotecnologia}

\subsubsection{Projeto de Lei 2.695/2003}

Em 2003, houve uma tentativa de reforma legislativa que pretendeu o reconhecimento expresso da patenteabilidade dos materiais biológicos e das sequências de DNA retirados do seu meio natural, sob a condição de que tenham aplicação industrial. Esta pretensão foi formalizada pela apresentação do Projeto de Lei 2.695/2003, de autoria do então Deputado Wilson Santos, que pretendeu atribuir ao artigo 10, inciso IX, da LPI, a seguinte redação:

\footnotetext{
"o todo ou parte de seres vivos naturais, os materiais biológicos encontrados na natureza e os processos biológicos naturais, exceto sequências totais ou parciais de ácido desoxirribonucleico e materiais biológicos isolados de seu entorno natural ou obtidos por meio de procedimento técnico, cujas aplicações industriais sejam comprovadas clara e suficientemente no pedido de patente".
}

Segundo entendimento do autor de referido projeto de lei, existiria uma proibição no inciso IX do artigo 10, da LPI, em desacordo com a posição da maioria dos países, que concede patente a material genético biológico purificado e isolado de seu entorno natural, desde que o material tenha aplicação industrial.

A nova redação visaria a promover a ciência e a biotecnologia e, ao mesmo tempo, manteria a restrição à patenteabilidade quanto a seres vivos naturais, materiais biológicos encontrados na natureza e processos naturais, de modo que não haveria qualquer ofensa ao ordenamento vigente.

Em dezembro de 2004, o então Deputado Paulo Baltazar houve por bem requerer a inclusão da Comissão do Meio Ambiente e Desenvolvimento Sustentável (CMADS) para manifestar-se sobre o Projeto de Lei 2.695/2003, por entender que se trataria de matéria afeta à área de atuação da Comissão. 
Neste mesmo ano, a ABPI, por meio da edição de sua Resolução 53/2003, recomendou ao governo brasileiro que assegurasse a introdução de medidas previstas na MP 2.186-16/2001 nas negociações internacionais.

De acordo com a ABPI, as sequências isoladas do ambiente natural seriam obtidas por descoberta e não invenção, ao contrário de organismos geneticamente modificados não havendo espírito criativo no desenvolvimento de algo novo (atividade inventiva - art. $8^{\circ}$ ) a ser protegido.

Ainda sobre o Projeto de Lei 2.695/2003, em 21/10/2004 foi emitida a Resolução ABPI 61/2004, que traz novos elementos à discussão em pauta e sugere a sua aprovação com modificações à nova redação do artigo 10, inciso IX, da LPI.

Para tanto, a ABPI levantou, em primeiro lugar, que o TRIPS não prevê restrições à patenteabilidade de material isolado da natureza, desde que preencha todos requisitos estabelecidos pelas jurisdições locais.

Nada obstante, leva também em consideração que existe, realmente, uma tendência mundial direcionada ao reconhecimento de patentes de material biológico purificado ou isolado, desde que tenha aplicação industrial, e que a biodiversidade brasileira apresenta grande potencial de desenvolvimento biotecnológico.

Neste contexto, a atual redação poderia levar a interpretações mais restritivas, de forma que o artigo 10, inciso IX, da LPI, poderia representar um entrave ao desenvolvimento científico e tecnológico. E que, ao lado disso, o INPI já aceita, pelas Diretrizes de Exame, reivindicações de material isolado cuja novidade reside no grau de pureza e/ou aspectos morfofuncionais diferenciados. E assim, oferece uma nova proposta de redação, que estabeleceria o seguinte:

"IX - o todo ou parte de seres vivos naturais, os materiais biológicos encontrados na natureza e os processos biológicos naturais, exceto sequências totais ou parciais de ácido desoxirribonucleico e materiais biológicos isolados 
de seu entorno natural ou obtidos por meio de procedimento técnico, cujas aplicações industriais sejam descritas de forma clara no pedido de patente."223

Esta nova redação sugerida mantém a não patenteabilidade de seres vivos naturais, materiais biológicos encontrados na natureza e processos naturais, porém, permite o patenteamento de materiais biológicos retirados do meio natural e sequências de DNA, desde que tenham aplicação industrial - restringindo assim o patenteamento indiscriminado, por requerer a comprovação clara e suficiente da aplicação industrial no pedido de patente.

Muito embora esta resolução não tenha sido tratada em nenhum dos pareceres apresentados na tramitação do Projeto de Lei em questão, o então Deputado Edson Duarte menciona expressamente a Resolução 53, da ABPI. De acordo com o Presidente da ABPI, que enviou correspondência aos deputados em 4 de outubro de 2005, a Resolução ABPI 53 foi citada fora de contexto e que o parecer não mencionou a Resolução ABPI 61, esta sim objeto do Projeto de Lei 2.695/2003. E, em razão disso, ressalta que o parecer equivocadamente não entendeu que o texto do PL representava uma exceção da exceção ou seja, que o PL propõe a permissão do patenteamento de substâncias naturais isoladas da natureza e não o patenteamento de substâncias tais como existem na natureza (pois, nesse caso, haveria descoberta, que não é patenteável) ${ }^{224}$.

Em 2005, o Deputado Edson Duarte, ao avaliar e discutir a respeito da exceção à restrição prevista no artigo 10 , da LPI, entendeu que ela viola os princípios da CDB, a Medida Provisória 2.186-16, de 2001, segundo a qual a utilização de recursos genéticos e dos conhecimentos tradicionais deveria atender à repartição justa e equitativa dos benefícios - repartição esta que não ocorreria entre o detentor da patente e os detentores da biodiversidade (União) ou dos conhecimentos associados (população tradicional).

\footnotetext{
223 "No entanto, o texto original do PL pode ainda restringir patenteamento de algumas substâncias naturais isoladas da natureza ao exigir que se COMPROVE clara e suficientemente a aplicação industrial de uma invenção no pedido de patente" (Resolução $\mathrm{n}^{\circ}$ 61/2004). Assim, troca-se o termo "comprovadas" por "descritas". Texto original do PL: "IX - o todo ou parte de seres vivos naturais, os materiais biológicos encontrados na natureza e os processos biológicos naturais, exceto sequências totais ou parciais de ácido desoxirribonucleico e materiais biológicos isolados de seu entorno natural ou obtidos por meio de procedimento técnico, cujas aplicações industriais sejam comprovadas clara e suficientemente no pedido de patente."

${ }^{224}$ A íntegra da correspondência encontra-se no Boletim da ABPI, n. 69, set/2005, p. 7, disponível em http://www.abpi.org.br/materiais/boletim/Bol69.pdf. Acesso em 11/12/14.
} 
Sob este contexto, entendeu que o artigo 31, da MP 2.186-16/2001, regulamentador do artigo $225, \S 1^{\circ}$, inciso II, $\mathrm{CF} / 88$, permitiria a utilização comercial de processos e produtos derivados do patrimônio genético, mas não do material genético em si, que é matéria prima para o desenvolvimento de produtos e processos - garantindo, assim, estrita observância aos princípios da CBD. Ato contínuo, o patenteamento de DNA causaria prejuízos à pesquisa científica, pois o desenvolvimento de novas pesquisas dependeria da concordância do detentor da patente, com possibilidade de pagamento de royalties.

O deputado apresentou seu voto, contrário à aprovação do Projeto de Lei, por considerar que a exceção prevista no projeto seria contrária: (a) à regulamentação do art. $225, \S 1^{\circ}, \mathrm{II}, \mathrm{CF} / 88$; (b) à CDB; (c) à recomendação da $\mathrm{ABPI}$; e (d) à condição de invenção, inerente a qualquer patente.

Em 10 de agosto de 2005, a CMADS, rejeitou o projeto, nos termos do parecer do Relator Deputado Edson Duarte. Não foram apresentadas emendas ao projeto por esta comissão.

A Comissão de Desenvolvimento Econômico, Indústria e Comércio (CDEIC), por sua vez, em 2006, embasada no voto de relatoria do Deputado Leo Alcântara, entendeu que as patentes: (a) por um lado ampliariam o grau de apropriabilidade de uma invenção, garantindo a fruição dos benefícios econômicos pelo titular e fomentando o investimento; (b) por outro, confeririam direito de uso exclusivo ao titular, sendo que se pode gerar monopólio, que provoca ineficiência econômica; e (c) gerariam efeitos ambíguos sobre a difusão do conhecimento - a disponibilização de dados da inovação (artigos 24 a 26, LPI) facilita o acesso à informação, em comparação com o trade secret, mas a possibilidade de novas invenções depende do escopo/abrangência da proteção conferida (se for muito amplo, pode deixar de existir o "transbordamento tecnológico" - externalidades positivas , tornando-se uma barreira à difusão tecnológica).

E, de acordo com os artigos 10, inciso IX, e 18, ambos da LPI, podem ser patenteáveis, como invenções ou modelos de utilidade: (a) os processos de isolamento de materiais biológicos e DNA; (b) os processos de utilização de materiais biológicos e DNA; e (c) produtos não naturais que contenham produtos biológicos naturais. Haveria, portanto, possibilidades de patenteamento na área de biotecnologia, com uma abrangência que 
incentiva investimentos de pesquisas, com razoável garantia de apropriabilidade dos benefícios, e que não permite o surgimento de "patentes guarda-chuva", que bloqueiam a exploração econômica de inovações correlatas por terceiros, razão pelo qual votou pela rejeição do projeto de lei.

O projeto de lei foi finalmente arquivado sob o fundamento de que violaria a regulamentação do inciso II do $\S 1^{\circ}$ do artigo 225 da $\mathrm{CF} / 88$, bem como a $\mathrm{CDB}$ (da qual o Brasil é signatário), cujo objetivo principal seria assegurar a manutenção do acervo genético sob o domínio público.

\subsubsection{Projeto de Lei 4.961/2005}

Da mesma forma, o Projeto de Lei 4.961/2005, de autoria do então deputado Antônio Carlos Mendes Thame (PSDB/SP), pretendeu alterar dispositivos da LPI para fins de regulamentar aspectos relacionados à patente biotecnológica.

Neste contexto, teve por objetivo a propositura de novas redações ao inciso IX do artigo 10, e ao inciso III do artigo 18, da LPI, cujas redações sugeridas eram as seguintes:

“IX - o todo ou parte de seres vivos naturais e materiais biológicos encontrados na natureza, inclusive o genoma ou germoplasma de qualquer ser vivo natural e os processos biológicos naturais, exceto substâncias e materiais biológicos obtidos, extraídos ou isolados da natureza que atendam aos requisitos de patenteabilidade previstos no art. $8^{o,}$

"III - o todo ou parte de seres vivos, exceto os microrganismos transgênicos e as substâncias e materiais biológicos obtidos, extraídos ou isolados da natureza previstos no inciso IX do art. 10, que atendam aos requisitos de patenteabilidade previstos no art. $8^{\circ}$ e que não sejam mera descoberta."

Em 14 de dezembro de 2004, o Relator da CMADS, Dep. Jorge Pinheiro (PL-DF), opinou pela sua rejeição, por entender que esta alteração legislativa permitiria a exploração comercial de processos ou produtos originados do patrimônio genético que pertenceriam a coletividade e estariam privilegiando meras descobertas da natureza, o que implicaria num 
entrave ao desenvolvimento da pesquisa científica. Relevante destacar de seu voto o seguinte trecho:

“(...) Todo o desenvolvimento de pesquisas com material patenteado, quer essas tivessem motivação comercial ou apenas acadêmica, ficaria dependente de concordância do detentor da patente, provavelmente vinculada ao pagamento de royalties, o que preocupa sobremaneira o Governo brasileiro (...)

Cumpre ainda ressaltar que é requisito incontestável ao registro de uma patente o caráter de invenção, ou seja, de envolvimento do espírito criativo no desenvolvimento de algo novo. Por conseguinte, a mera descoberta de um produto biológico, na condição em que ele se encontra naturalmente, não permite seu patenteamento. Toda substância extraída de seres vivos naturais (ou seja, não geneticamente modificados) só pode, por definição, ser descoberta, e não "inventada". 225

Em abril de 2006, contudo, o deputado Hamilton Casara (também da CMADS), apresentou voto contrário concluindo que "a redação atual da nossa Lei de Propriedade Industrial está em contradição com os preceitos aplicáveis ao tema instituídos pelo Acordo TRIPS e destoa de princípios legislativos vigentes em países industrializados, em particular integrantes da União Européia"226.

Logo em seguida, em novembro daquele mesmo ano, o Dep. Jorge Pinheiro reviu o seu entendimento inicial, alinhando-o ao do Dep. Hamilton Casara, e passou a buscar aprovação sem restrições do projeto de lei.

No âmbito da discussão de referido projeto de lei, cabe ainda destacar convergência existente entre a presente Proposição da lavra do deputado Antonio Carlos Mendes Thame e a opinião manifestada pela Confederação Nacional da Indústria (CNI), na Agenda Legislativa da Indústria 2006, Brasília, p. 20, que transcrevemos:

\footnotetext{
${ }^{225}$ BRASIL. Câmara dos Deputados. Portal da Câmara. Voto do Dep. Jorge Pinheiro sobre o Projeto de Lei $\mathrm{n}^{\text {o }} \quad 4.961 / 05$. Disponível em: http://www.camara.gov.br/proposicoesWeb/prop_mostrarintegra?codteor $=364394 \&$ filename $=$ TramitacaoPL+4961/2005. Acesso em: ?

${ }^{226}$ BRASIL. Câmara dos Deputados. Portal da Câmara. Voto em Separado do Dep. Hamilton Casara sobre o Projeto de Lei $\quad \mathrm{n}^{\circ} \quad 4.961 / 05$. http://www.camara.gov.br/proposicoesWeb/prop mostrarintegra?codteor $=387098 \&$ filename $=$ TramitacaoPL+4961/2005. Acesso em:?
} 


\begin{abstract}
"As restrições à patenteabilidade de inventos relacionados a usos e aplicações de matérias obtidas de organismos naturais desestimulam investimentos públicos e privados direcionados ao conhecimento e ao aproveitamento econômico da flora e da fauna brasileiras. A impossibilidade do patenteamento de materiais biológicos, mesmo que retirados da natureza ou separados do seu entorno, está em desacordo com a postura adotada pela maioria dos países de conceder patente a material biológico purificado e isolado de seu entorno, desde que este material tenha aplicação industrial. ${ }^{, 227}$
\end{abstract}

Em 12 de setembro de 2008, foi apresentado o parecer rejeitando a proposta pelo Dep. Germano Bonow, por entender que seria "contrária à regulamentação do inciso II do $\S 1^{\circ}$ do art. 225 da Constituição, à Convenção sobre Diversidade Biológica, à recomendação da ABPI e à condição de invenção, imprescindivel ao registro de qualquer patente, e que a proposição apensada traria enormes prejuízos às pesquisas com organismos geneticamente modificados, realizadas atualmente ao abrigo das Leis $9.279 / 96$ e $11.105 / 05^{, 228}$.

Contudo, em Setembro de 2009, o Dep. Germano Bonow apresentou complementação ao seu parecer, reconhecendo a necessidade de políticas de aproveitamento da biodiversidade e sua vinculação à inovação científica e tecnológica, passando a defender a aprovação do Projeto de Lei 4.961/05, na forma do substitutivo que prevê a possibilidade de patenteamento de "substâncias e materiais biológicos obtidos, extraídos ou isolados da natureza", desde que atendidos aos requisitos de patenteabilidade previstos no artigo $8^{\circ}$, da LPI, sendo necessário também que sejam "atendidas as disposições previstas na legislação de acesso aos recursos genéticos". Também se posicionou pela rejeição do Projeto de Lei 654/07.

Em 29 de agosto de 2013, foi apresentado o parecer do Dep. Newton Lima, designado relator pela CCTCI, que foi pela rejeição deste e do PL 654/2007, apensado -

\footnotetext{
${ }^{227}$ BRASIL. Câmara dos Deputados. Portal da Câmara. Voto do Dep. Jorge Pinheiro sobre o Projeto de Lei $\mathrm{n}^{\circ} \quad 4.961 / 05$. Disponível em: http://www.camara.gov.br/proposicoesWeb/prop mostrarintegra?codteor=425996\&filename=TramitacaoPL+4961/2005. Acesso em: ?

${ }^{228}$ BRASIL. Câmara dos Deputados. Portal da Câmara. Voto do Dep. Germano Bonow sobre o Projeto de Lei $\quad \mathrm{n}^{\circ} \quad 4.961 / 05 . \quad$ Disponível em: http://www.camara.gov.br/proposicoesWeb/prop mostrarintegra?codteor $=597984 \&$ filename $=$ TramitacaoPL+4961/2005. Acesso em: ?
} 
justificando seu voto na decisão da Suprema Corte Americana, que recentemente negou o status de invenção patenteável aos genes isolados ${ }^{229}$.

Mais recentemente, no dia 27 de agosto de 2014, o Dep. Valdivino de Oliveira, apresentou parecer favorável à aprovação Projeto de Lei 4.961/05, na forma do Substitutivo originado do parecer do Dep. Germano Bonow, relator da CMADS, e pela rejeição do PL 654/2007:

\begin{abstract}
"Por representar um avanço no marco regulatório sobre o patenteamento de substâncias ou matérias extraidas de ser vivo natural, obtidas ou isoladas, que apresentem os requisitos de patenteabilidade e criar incentivos para a pesquisa brasileira em biotecnologia, com a possibilidade de instituições, empresas e pesquisadores nacionais patentearem o resultado de seus atos inventivos, e que a proposição apensada traria enormes prejuizos às pesquisas com organismos geneticamente modificados, realizadas atualmente de acordo com as Leis 9.279/1996 e 11.105/2005 é que recomendamos a APROVAÇÃO do Projeto de Lei $n^{\circ} 4.961$ de 2005, NA FORMA DO SUBSTITUTIVO aprovado na COMISSÃO DO MEIO AMBIENTE E DESENVOLVIMENTO SUSTENTÁVEL, $e$ pela REJEIÇÃO do Projeto de Lei $n^{\circ} 654 / 2007^{, 230}$.
\end{abstract}

Atualmente, de sua última atualização feita em 29/10/2014, o projeto consta como “Aguardando Parecer do Relator na Comissão de Desenvolvimento Econômico, Indústria e Comércio (CDEIC)". O relator designado é o Dep. Laercio Oliveira.

\title{
5.1.5 Políticas de Apoio à Inovação Biotecnológica
}

Recentemente foram lançadas políticas de apoio à inovação biotecnológica, como é o caso da Política Industrial, Tecnológica e de Comércio Exterior (PITCE), que foi lançada em 2003 com o objetivo de promoção da inovação e fortalecimento da capacidade inovativa.

\footnotetext{
${ }^{229}$ BRASIL. Câmara dos Deputados. Portal da Câmara. Voto do Dep. Newton Lima sobre o Projeto de Lei n ${ }^{\circ}$ 4.961/05. Disponível em: http://www.camara.gov.br/proposicoesWeb/prop_mostrarintegra?codteor $=1123053 \&$ filename $=$ TramitacaoPL+4961/2005. Acessso em: ?

${ }^{230}$ BRASIL. Câmara dos Deputados. Portal da Câmara. Voto do Dep. Valdivino de Oliveira sobre o Projeto de Lei $\quad \mathrm{n}^{\circ}$ 4.961/05. Disponível em: http://www.camara.gov.br/proposicoesWeb/prop mostrarintegra?codteor $=1275429 \&$ filename $=$ TramitacaoPL+4961/2005. Acesso em: ?
} 
Neste contexto, foram editados os seguintes instrumentos jurídicos: (a) Lei 10.973/2004 (Lei da Inovação), (b) Lei 11.196/2005 (Lei do Bem) e (c) Decreto 6.041/2007. Há também outros instrumentos que os complementam.

Em 2004, entrou em vigor a chamada Lei de Inovação (Lei 10.973/2004), que teve como objetivo flexibilizar a articulação público-privada, incluindo medidas de incentivo, com a regulamentação da titularidade da propriedade intelectual e estímulo à cooperação entre instituições públicas e privadas, por meio, dentre outros, da dispensa de licitação para o licenciamento de propriedade intelectual.

Em seguida, foi editada a Lei do Bem, que regulamenta um conjunto de incentivos às atividades de $\mathrm{P} \& \mathrm{D}$, inclusive a concessão de subvenção, pelas agências de fomento, para a remuneração de pesquisadores empregados em atividades de inovação tecnológica sem, contudo, referir-se especificamente às inovações biotecnológicas.

Por meio do Decreto 6.041/2007, foi também neste mesmo ano criado o Centro Nacional de Biotecnologia (CNB) e instituída a Política de Desenvolvimento da Biotecnologia (PDB), visando ao estabelecimento de um ambiente nacional adequado ao desenvolvimento de produtos e processos biotecnológicos inovadores, bem como de aumento da eficiência e capacidade de inovação das empresas brasileiras - com foco em saúde humana, agropecuária, indústria e meio ambiente.

A PDB teve como objetivo a criação de um ambiente favorável no Brasil a fim de promover mais investimentos em $\mathrm{P} \& \mathrm{D}$, aumento no número de depósitos de patentes e metas de exportação dos novos produtos nas áreas genômica, pós-genômica, proteômica, nano biotecnologia, células-tronco e neurociência.

Além disso, estabeleceu como objetivo a implantação de um Centro Depositário de material biológico para fins patentários e a agilização dos procedimentos de concessão de patentes de biomateriais. Nada obstante, apresenta também o objetivo de estimular a prospecção de patentes em métodos, substâncias, marcadores e testes para uso em kits diagnósticos. 
Foi também lançado em 2007 o Plano de Ação em Ciência, Tecnologia e Inovação para o Desenvolvimento Nacional (PACTI), que possui segmento voltado à Pesquisa, Desenvolvimento e Inovação (PD\&I) dentro do qual se insere a Rede Nacional Genômica, que tem por objetivo a definição de iniciativas, ações e programas de apoio ao sistema CT\&I, em busca de aprimoramento dos marcos regulatórios de biossegurança, biodiversidade, propriedade intelectual e outros para adequação aos processos inovadores na área de biotecnologia.

Há, ainda, o programa Competitividade em Biotecnologia, cuja finalidade reside no incentivo de ações voltadas ao desenvolvimento e à inovação em setores estratégicos de aplicação da tecnologia.

Em 2008, a PITCE foi substituída pela Política de Desenvolvimento Produtivo (PDP), criando novos instrumentos para política industrial; dentre as dificuldades inerentes ao desenvolvimento de seu programa encontra-se o aumento dos investimentos públicos e privados, o desenvolvimento nacional de produtos e processos em áreas estratégicas e o estabelecimento de ambiente regulatório capaz de induzir atividade inovadora na área da biotecnologia.

Em 2011, a PDP foi substituída pelo Plano Brasil Maior (que permaneceu vigente durante os anos de 2011 a 2014), que teve como foco principal o estímulo à inovação e à produção nacional visando ao aumento da competitividade nacional nos mercados interno e externo; os incentivos à inovação a biotecnológica, contudo, não foi um dos segmentos diretamente contemplados pelo Plano Brasil Maior.

A Estratégia Nacional de Ciência, Tecnologia e Inovação (ENCTI) veio em 2011 para substituir o PACTI, estabelecendo diretrizes que buscam consolidar um sistema nacional de Ciência, Tecnologia \& Inovação (CT\&I) capaz de conjugar esforços em todos os âmbitos - federal, estadual, municipal, público e privado - durante os anos de 2012 a 2015, relacionadas aos setores considerados mais de vanguarda na área de ciência e tecnologia, "preparando o Brasil para a economia do conhecimento e da informação, auxiliando na transição para uma economia verde e criativa e contribuindo para a inclusão produtiva". 
Dentre os programas considerados prioritários para a ENCTI, destacam-se as tecnologias da informação e comunicação, fármacos e complexo industrial da saúde, petróleo e gás, complexo industrial da defesa, aeroespacial, nuclear e áreas relacionadas com a economia verde e o desenvolvimento social ${ }^{231}$.

\subsection{Legislações Internacionais}

$\mathrm{O}$ arcabouço jurídico internacional relativo à biotecnologia é altamente complexo e fragmentado, uma vez que cada regime constitutivo foi criado em períodos históricos distintos e com finalidades distintas, muitas vezes não abordando prioritariamente a governança da propriedade intelectual.

No plano internacional, importam ao presente estudo tratados/convenções dos quais o Brasil é signatário: (a) o Tratado de Cooperação Patentária (PTC); (b) o Acordo sobre Aspectos dos Direitos de Propriedade Intelectual Relacionados ao Comércio (TRIPS); (c) a Convenção de Paris (CUP); (d) a Convenção Sobre Diversidade Biológica (CDB).

Além dos acordos/tratados internacionais acima mencionados, importa dizer que há ainda outros que regulam aspectos biotecnológicos em relação à propriedade intelectual, tais como a International Union for the Protection of New Varieties of Plants (UPOV) e a Tirfaa-FAO; entretanto, por se referirem especificamente a recursos genéticos relacionados a plantas, não integram o presente estudo.

\subsubsection{PCT}

O Brasil é signatário do PCT desde 1978. Ao contrário do que se pode imaginar, referido acordo não fere a soberania dos países signatários, na medida em que ele não cria uma patente internacional. Trata-se de um processo que permite o depósito de reivindicações patentárias simultaneamente em qualquer país signatário do PCT.

${ }^{231}$ BRASIL. Ministério da Ciência, Tecnologia e Inovação (MCTI). Estratégia Nacional de Ciência, Tecnologia e Inovação 2012 - 2015 Balanço das Atividades Estruturantes - 2011. Disponível em: http://www.mct.gov.br/upd_blob/0218/218981.pdf. Acesso em 26/10/2014, p. 24-25. 
O processo, gerenciado pela Organização Mundial de Propriedade Intelectual (OMPI), envolve uma fase internacional, que verifica a possibilidade de patenteamento do objeto da reivindicação nos países indicados no respectivo requerimento. Em seguida, tem início a fase nacional, a ser realizada em cada um dos países, de acordo com seus próprios procedimentos e regras.

Uma das grandes vantagens deste acordo é a redução de custos e tempo necessários à obtenção da proteção patentária de forma individual, em cada uma das jurisdições pretendidas pelo inventor.

\subsubsection{CUP}

O Brasil é também signatário da CUP, que estabeleceu uma das primeiras legislações internacionais sobre propriedade industrial. Referido texto legal foi objeto de 02 revisões: em 1929, por meio da Revisão de Haia, promulgada no Brasil por meio do Decreto 19.056/1929; e em 1975, por meio da Revisão de Estocolmo, integrada ao ordenamento jurídico nacional por meio do Decreto 75.572/1975.

A CUP apresenta um padrão mínimo de proteção dos direitos imateriais e de tratamentos igualitários ente as nações, que deve ser assimilado por todos os países membros. Por meio dela foram também instituídas regras fundamentais, tais como o direito de prioridade e a regra de independência da patente. $\mathrm{O}$ direito da prioridade parece ser a mais importante contribuição da CUP, pois ela autoriza àqueles que depositarem pedido de proteção de direito de propriedade intelectual em determinada jurisdição a sua posterior extensão para outros países membros, garantindo-se a data do depósito original.

Neste sentido, a CUP determinou também uma forma de padronização dos procedimentos, por meio do estabelecimento de serviços nacionais de propriedade industrial e de um escritório central para a comunicação das patentes concedidas.

Entretanto, muito embora exista uma busca pela padronização de regras e procedimentos, isso não evita ou substitui a obrigatoriedade de que cada reivindicação seja 
recebida, processada e analisada individualmente em cada país membro, de acordo com seus respectivos trâmites formais e de acordo com suas próprias leis.

\subsubsection{TRIPS}

No ano de 1994, o TRIPS foi promulgado pelo Decreto 1.355/1994, incorporando ao ordenamento jurídico pátrio os Resultados da Rodada Uruguai de Negociações Comerciais Multilaterais do GATT (incluindo o TRIPS). No entanto, após uma mudança de posicionamento do Superior Tribunal de Justiça (STJ) ${ }^{232}$, o TRIPS passou a ter aplicabilidade somente a partir de $1^{\circ}$ de Janeiro de 2000 no Brasil.

O TRIPS estabeleceu padrões mínimos a que os membros signatários deverão estar adstritos, a fim de promover a universalização das regras e diretrizes que devem nortear a tutela dos direitos de propriedade intelectual. Para tanto, prevê o TRIPS a obrigatoriedade da adequação de seus ordenamentos jurídicos internos pela incorporação de suas regras.

O seu artigo 27 estabelece que qualquer invenção, em todos os setores tecnológicos, poderá ser patenteada, desde que cumpridos os requisitos de novidade, passo inventivo e aplicação industrial.

Tais requisitos admitem diferentes interpretações nas diversas jurisdições; da mesma forma, os Estados Membros podem também considerar como não patenteáveis as invenções cuja exploração seja necessária evitar por razões de ordem pública ou moralidade, bem como para se proteger o meio ambiente, as plantas e os animais (exceto os microrganismos e processos essencialmente biológicos para a produção de plantas e animais, excetuando-se os processos não-biológicos e microbiológicos).

\footnotetext{
${ }^{232}$ Da ementa (REsp no 642213 / RJ (2004/0003826-7): “3. Mesmo que vigente o TRIPs desde $1^{\circ}$ da janeiro de 1995 em face de sua ratificação e promulgação, a regra prescrita no seu art. 65, 2 - "Um país em desenvolvimento Membro tem direito a postergar a data de aplicação das disposições do presente Acordo, estabelecida no parágrafo $1^{\circ}$, por um prazo de quatro anos, com exceção dos Artigos 3, 4 e 5" -, por se constituir uma reserva concedida ao Brasil, sintetiza direito norteador de amparo ao reconhecimento de que a entrada em vigor no Acordo veio a ocorrer somente em $1^{\circ}$ de janeiro de 2000, inibindo, portanto, sua plena incidência a partir da publicação oficial. 4. Por não gerar o TRIPs obrigações relativas a atos ocorridos antes de sua data de aplicação para o respectivo Membro (art. 70, I), em harmonia com o direito de preterir os períodos de incidência do Acordo (art. 65), é manifesta a inexistência de imposição da sua observância no tocante a privilégios de invenção anteriormente concedidos, uma vez que não patenteado nenhum propósito de sua auto-aplicabilidade ou de sua aptidão para abarcar relações jurídicas afora aquelas que somente convergem para os seus Membros, tampouco qualquer comando preceptivo que permita a extensão do prazo de vigência da patente deferido com suporte na Lei $n$. 5.772/71."
} 
O TRIPS igualmente permite aos países signatários a exclusão do âmbito de proteção patentária dos métodos diagnósticos, terapêuticos e cirúrgicos, bem como autoriza os governos dos países signatários a negar patentes a qualquer invenção, a fím de proteger a saúde e a vida humana.

No TRIPS não há uma definição para o termo “invenção" e, portanto, os produtos que ocorrem naturalmente - como as proteínas - não estariam a priori excluídos de patenteabilidade no âmbito do tratado. Se o isolamento do produto natural for realizado com esforço técnico e intelectual, e se este produto possuir alguma característica que o possa distinguir da forma em que se encontra na natureza, este produto seria objeto de proteção patentária. Entretanto, como já discutido, este produto pode contar com uma forma materialmente diversa, porém codificar a mesma função biológica, o que levou algumas jurisdições a não recepcionarem os genes isolados de seus meios naturais como matéria passível de patenteamento.

Com base no TRIPS, há portanto quatro posicionamentos possíveis de adoção pelos Estados Membros, com relação às matérias biológicas: (a) conceder patentes a toda e qualquer espécie de invenção, incluindo-se plantas, animais e processos biológicos; (b) excluir, plantas, animais e processos biológicos, mas não as variedades de plantas; (c) excluir também as variedades de plantas, mas introduzir um regime sui generis para sua proteção; (d) não excluir as variedades de plantas e oferecer além do patenteamento, um regime sui generis.

O artigo 31 do TRIPS, por sua vez, prevê também a possibilidade de se ignorarem patentes na área de saúde por meio da concessão de licenças compulsórias para que terceiros produzam versões do bem patenteado. A licença compulsória permite ao estado a concessão do direito de exploração do bem patenteado por terceiros sem o prévio consentimento do proprietário da patente.

Há, por fim, inconsistências na relação entre TRIPS e CDB, pois aquele não exige que os requerentes de patentes para invenções que incorporem material genético ou conhecimentos tradicionais cumpram as obrigações acordadas na CDB. Os países em subdesenvolvimento, em geral, defendem a emenda do Acordo no Conselho TRIPS, 
enquanto os desenvolvidos apoiam soluções alternativas no âmbito da OMPI, que possuiria o conhecimento técnico para oferecer a solução, além de a agenda da Rodada Doha na OMC já estar sobrecarregada.

\subsubsection{CDB}

A CDB está estruturada sobre os seguintes pilares: (a) conservação da diversidade biológica; (b) o uso sustentável da biodiversidade; e (c) a repartição justa e equitativa dos benefícios provenientes da utilização dos recursos genéticos.

A CDB tem por objetivo a identificação, a catalogação, o armazenamento, a conservação e o uso sustentável da biodiversidade e a proteção do conhecimento tradicional, reconhecendo-se seu valor com a regulação de uso e acesso. E, desta forma, proclama a soberania dos países sobre os recursos biológicos encontrados em seus territórios, o que assegura aos países detentores de recursos biológicos e responsáveis pela manutenção de tais recursos- historicamente desprovidos da tecnologia e recursos financeiros necessários para uma adequada exploração, a possibilidade de participarem dos resultados econômicos eventualmente advindos de tais recursos.

Na Conferência das Partes, em Nagoya (2010), aprovou-se Protocolo segundo o qual os países têm soberania sobre recursos genéticos de sua biodiversidade, que se podem acessar apenas com o consentimento daqueles - além disso, caso o acesso resulte em lucros de produção e comercialização, estes devem ser compartilhados com o país de origem. No entanto, o Protocolo de Nagoya não garantiu o acesso facilitado aos Judiciários nacionais nem negou o patenteamento no exterior de recursos genéticos e conhecimentos tradicionais associados obtidos sem a anuência dos titulares (países e comunidades).

É um dos acordos internacionais com maior número de membros, e o Brasil é parte da CDB desde 1994. No entanto, ainda não foi ratificada pelos EUA, segundo o qual a Convenção ameaça direitos de propriedade garantidos no país e no TRIPS. 


\subsection{Evolução legislativa e jurisprudencial em matéria de biotecnologia nos EUA}

Os EUA participam de 53\% das 50 principais regiões em depósitos de patentes via acordos de cooperação em biotecnologia (das quais 49 localizam-se em mercados desenvolvidos). Além disso, participa de $41,5 \%$ do total de patentes submetidas no sistema PCT, enquanto UE e Japão, somados, participam de 39,4\% das patentes submetidas. Favorecem as empresas de biotecnologia a presença de mão de obra qualificada e de firmas de venture capital.

Originalmente, a lei americana proibia o patenteamento em invenções na área de saúde. Durante os 150 primeiros anos de história americana, o USPTO não concedeu patentes para métodos usados para diagnosticar e tratar pacientes. Àquela época, tais patentes não eram concedidas, pois não se tratava de invenções tangíveis.

Entretanto, como será identificado nos Capítulos seguintes, a lei de propriedade intelectual e a orientação jurisprudencial americanas têm propiciado um ambiente de fomento à inovação e ao progresso tecnológico por "encorajar o desenvolvimento de novos produtos e descobertas, novos usos para antigos produtos" ${ }^{, 233}$, especialmente na área de biotecnologia - sendo tal afirmação corroborada por uma das mais importantes e pioneiras decisões relativas a invenções biotecnológicas, exaradas no caso Diamond $v$. Chakrabarty ${ }^{234}$, segundo a qual "qualquer coisa produzida pelo homem pode ser patenteável".

Há na legislação americana atual, pois, uma preocupação especial com tecnologias de manipulação genética, dentre elas tecnologias de DNA e RNA recombinantes, além de um controle de testes e procedimentos específicos para cada caso. Além da manutenção de bancos de dados sobre sequências de nucleotídeos e aminoácidos, há aprimoramento de recursos e estrutura para armazenamento das informações biotecnológicas.

\footnotetext{
${ }^{233}$ Cf. "Estudo Comparativo dos Critérios de Patenteabilidade para Invenções Biotecnológicas em Diferentes Países", publicado pelo INPI em julho de 2007, p. 36.

${ }^{234}$ Este caso americano é objeto de estudo específico, conforme se pode depreender do Capítulo 5.3.4.6.
} 


\subsubsection{Legislação de patentes e proteção biotecnológica nos EUA}

A atual Constituição Americana estabelece que o fundamento da lei de patentes é a promoção do progresso da ciência e das artes úteis, pela concessão de exclusividade de exploração de referidas invenções e descobertas por determinado período de tempo.

A atual base legal americana, no que diz respeito especificamente às invenções biotecnológicas e suas possíveis formas de proteção, é encontrada nos seguintes dispositivos: (a) título 35 do Código dos Estados Unidos (USC); (b) título 37 do USC; (c) orientações/diretrizes do USPTO; e (d) jurisprudência.

À parte disso, há outros 2 importantes textos legais, a saber: há o Manual of Patent Examining Procedure (MPEP) - Capítulos 2400 (Biotechnology) e 2100, Seção 2105 (Patentable Subject Matter - Living Subject Matter), e o General Information About 35 USC 161 Plant Patents.

O título 35 do USC, em sua seção 101, assim descreve as invenções passíveis de patenteamento: qualquer invenção ou descoberta nova e útil, relativa a um processo, uma máquina, uma manufatura, ou composição da matéria, além de qualquer desenvolvimento útil deles originados, poderá ser objeto de proteção patentária ${ }^{235}$.

E tais matérias passíveis de patenteamento, para que efetivamente encontrem guarida na legislação norte-americana, deverão ainda observar as duas condições previstas nas seções 102 (novidade) e 103 (utilidade e não obviedade), ambas pertencentes ao título 35 do USC, ora em comento. Sendo assim, de forma semelhante aos requisitos brasileiros, para que uma patente seja considerada patenteável, o requerente deve demonstrar que se trata de uma "invenção" dotada de: (a) novidade (invenção não compreendida no estado da técnica); (b) não obviedade (a invenção não decorre de maneira evidente ou óbvia do estado da técnica - equivalente à atividade inventiva); e (c) utilidade.

${ }^{235}$ Título 35, seção 101, do USC: “Whoever invents or discovers any new and useful process, machine, manufacture, or composition of matter, or any new and useful improvement thereof, may obtain a patent therefore, subject to the conditions and requirements of this title". 
Ademais, referida lei americana exige que reivindicação da patente deve gozar de suficiência descritiva clara e não ambígua, que inclua o método preferido e de execução, e seja reproduzível por técnico no assunto (seção 112 do título 35 da USC). A reivindicação, portanto, deve ser clara e detalhar/descrever completamente a invenção, de modo a permitir que qualquer profissional qualificado na área técnica correspondente reproduza tal invenção, sendo certo que este requisito passou a ter crescente relevância na análise e concessão de invenções biotecnológicas, notadamente no que diz respeito aos genes humanos, como será visto oportunamente.

A lei americana não dispõe explicitamente que as descobertas não seriam matéria patenteável - prioriza-se o que se pode patentear. Mesmo a exceção de patenteamento de humanos não é estatuída legalmente. Entretanto, a legislação americana estabelece que não são patenteáveis reivindicações de patentes relativas a (a) artigos de ocorrência natural como sequências de DNA nativo ${ }^{236}$, e (b) plantas de reprodução de tubérculos e plantas silvestres (descobertas em estado não cultivado) ${ }^{237}$.

Nada obstante, verifica-se nos EUA que a proteção patentária de proteínas e genes purificados e isolados de sua ocorrência natural vinha sendo permitida há décadas, de forma indiscriminada. Porém, as diretrizes do USPTO para concessão de patentes desta natureza e as decisões judiciais evoluíram substancialmente nos últimos anos ${ }^{238} \mathrm{e}$, se por um lado, apontam no sentido de que a reivindicação de descoberta de um fenômeno natural ou produtos da natureza não pode por si só ser objeto de patente (por não ser cumprido o requisito da novidade), por outro, têm buscado incentivar uma intervenção humana técnica substancial capaz de justificar que seus resultados, mesmo quando originados de tais

\footnotetext{
${ }^{236}$ MPEP, Capítulo 2106: "Non-limiting examples of claims that are not directed to one of the statutory categories: (...) ii. a naturally occurring organism, Chakrabarty, 447 U.S. at 308, 206 USPQ at 197; (...)" (Disponível em: http://www.uspto.gov/web/offices/pac/mpep/s2106.html. Acesso em: ?). E "The rule against patents on naturally occurring things is not without limits, however, for 'all inventions at some level embody, use, reflect, rest upon, or apply laws of nature, natural phenomena, or abstract ideas,' and 'too broad an interpretation of this exclusionary principle could eviscerate patent law.' 566 U. S., at __(slip op., at 2) (...) It is undisputed that Myriad did not create or alter any of the genetic information encoded in the BRCA1 and BRCA2 genes." (Suprema Corte dos Estados Unidos. Association for Molecular Pathology et al. v. Myriad Genetics, inc., et al).

${ }^{237}$ Título 35, seção 161, do USC: "Patent for plants. Whoever invents or discovers and asexually reproduces any distinct and new variety of plant, including cultivated sports, mutants, hybrids, and newly found seedlings, other than a tuber propagated plant or a plant found in an uncultivated state, may obtain a patent therefor, subject to the conditions and requirements of this title [35 USCS Sects. 1 et seq.]. The provisions of this title [35 USCS Sects. 1 et seq.] relating to patents for inventions shall apply to patents for plants, except as otherwise provided".

${ }^{238}$ A evolução do entendimento do USPTO, evidenciado por suas diretrizes e subsequentes revisões, é objeto do Capítulo 5.3.3.
} 
objetos - em princípio excluídos da proteção - venham a se tornar novas patentes. E é neste contexto que se inserem os cases analisados a seguir.

\subsubsection{Evolução Legislativa nos EUA}

Nos EUA, a partir de 1789 foi outorgado poder ao Congresso Nacional para promover progresso técnico-cientifico por meio da concessão de direitos de propriedade por prazo determinado, que assegura aos seus criadores o direito exclusivo às suas invenções.

Já no ano seguinte foi publicada a primeira lei de patentes, que tinha por objetivo promover o progresso das "técnicas úteis". Referido texto legal foi substituído logo em 1793, já um pouco mais robusto, e definiu as características básicas para se determinar uma matéria patenteável nos EUA, que se assemelham em muito aos requisitos atuais de patenteabilidade: "qualquer técnica, máquina, produto ou composição útil, bem como qualquer melhoramento de técnica, máquina ou composição nova e útil”,239.

Em 1836 foi criado o USPTO, que se tornou o órgão responsável pelo exame da novidade da invenção que se pretendia patentear. Em 1952, houve uma reforma na lei de patentes que teve como uma de suas principais mudanças a inclusão do requisito de nãoobviedade. Esta novidade veio a consagrar a jurisprudência americana que já havia se consolidado neste sentido.

Isso se deu por meio da edição do Patent Act of 1952, que tem como uma das principais alterações a inclusão do requisito de não obviedade (non-obviousness). Este requisito, de acordo com a regra 65 , do PCT, seria equivalente ao requisito de passo inventivo (inventive step).

Já na década de 1980, os resultados decorrentes da decisão no caso Diamond $v$. Chakrabaty $^{240}$ e o estabelecimento do Bayh-Dole Act (que passou a permitir a obtenção da titularidade sobre patentes desenvolvidas com recursos públicos em ambiente acadêmico

\footnotetext{
${ }^{239} 35$ U.S.C. 101 - Inventions patentable: "Whoever invents or discovers any new and useful process, machine, manufacture, or composition of matter, or any new and useful improvement thereof may obtain a patent therefor, subject to the conditions and requirements of this title."

${ }^{240}$ Para maiores informações a respeito deste caso, vide Capítulo 5.3.4.6.
} 
ou em acordos de pesquisa colaborativa mista) levaram a um processo de liberação de recursos e produtos de pesquisa dos institutos de pesquisa e centros universitários para o setor empresarial privado dos EUA.

Em 2002 foi apresentado um projeto que pretendia isentar provedores de saúde que realizassem testes genéticos do pagamento de royalties aos detentores das patentes de gene. Este projeto partia justamente da premissa de que as leis de propriedade intelectual e transferência de tecnologia estimulariam o desenvolvimento de inovações genéticas por atraírem investimentos, mas que, por outro lado, poderiam inibir o compartilhamento de informações, e, consequentemente, a inovação ${ }^{241}$.

Atualmente, o Título 35 do USC, em sua seção 101, descreve as invenções passíveis de patenteamento:

\footnotetext{
"Whoever invents or discovers any new and useful process, machine, manufacture, or composition of matter, or any new and useful improvement thereof, may obtain a patent therefore, subject to the conditions and requirements of this title."
}

Além disso, outras 2 condições para a obtenção de patente estão nas seções $102 \mathrm{e}$ 103: "Novelty/Prior Art" ${ }^{, 42}$ e "non-obvious subject matter"243. Sendo assim, de forma

241 "In 2002 Representative Lynn Rivers (D-MI) introduced into Congress the Genomic Research and Diagnostic Accessibility Act ("GRDAA"), a bill that would have provided limited exemptions from liability for certain uses of patented genetic sequences and genetic sequence information in the context of basic research and genetic diagnostic testing. Importantly, the GRDAA would not have affected the patentability of genetic inventions, the approach taken in a more recent legislative initiative discussed below" (HOLMAN, Christopher M., Recent Legislative Proposals Aimed At The Perceived Problem Of Gene Patents. American Bar Association, 2008, p. $\quad 2 . \quad$ Disponível em http://www.americanbar.org/content/dam/aba/migrated/scitech/biotech/pdfs/recent_legislative_chris_holman. authcheckdam.pdf).

242 "35 U.S. Code $\$ 102-$ Conditions for patentability; novelty.

(a) Novelty; Prior Art - A person shall be entitled to a patent unless -

(1) the claimed invention was patented, described in a printed publication, or in public use, on sale, or otherwise available to the public before the effective filing date of the claimed invention; or

(2) the claimed invention was described in a patent issued under section 151, or in an application for patent published or deemed published under section 122 (b), in which the patent or application, as the case may be, names another inventor and was effectively filed before the effective filing date of the claimed invention."

243 "35 U.S.C. 103 - Conditions for patentability; non-obvious subject matter.

A patent for a claimed invention may not be obtained, notwithstanding that the claimed invention is not identically disclosed as set forth in section 102, if the differences between the claimed invention and the prior art are such that the claimed invention as a whole would have been obvious before the effective filing date of the claimed invention to a person having ordinary skill in the art to which the claimed invention pertains. Patentability shall not be negated by the manner in which the invention was made." 
semelhante aos requisitos brasileiros, tais condições são: (a) novidade (invenção não compreendida estado da técnica); (b) não obviedade (critério equivalente à atividade inventiva); e (c) utilidade.

\subsubsection{A Evolução do USPTO no tratamento das patentes biotecnológicas}

As primeiras patentes de método sobre invenções biotecnológicas com DNA recombinante foram reconhecidas pelo USPTO na década de 1970. Nesta mesma linha, em 1980, o USPTO concedeu às Universidades de Stanford e da Califórnia, após 6 anos de análise, patente sobre a método de DNA recombinante, que permite a manipulação de material genético (as patentes Cohen-Boyler).

No ano de 1987, a USPTO concedeu patente sobre o PCR, essencial à biotecnologia por admitir a amplificação seletiva de fragmentos de DNA (US4683195), permitindo a detecção rápida e fiel dos marcadores genéticos de doenças infecciosas ou genéticas $^{244}$.

Neste mesmo ano, o USPTO declarou que passaria a considerar matéria patenteável, nos termos da seção 101 do título 35, do USC, os organismos multicelulares vivos não humanos, que não tenham ocorrência natural - incluindo animais, bem como os processos de produção de referidos organismos multicelulares e de seus possíveis usos em testes e processos de síntese proteica (Animals - Patentability, 1077 O.G. 24, April 21, 1987).

Já no ano de 1988, o USPTO concedeu a primeira patente sobre um animal transgênico, um camundongo, utilizado em pesquisas sobre o câncer (oncomouse), sendo este um marco de grande importância, a partir do qual diversos outros se desenvolveram ${ }^{245}$..

Em 1993, o USPTO inseriu, por meio da $15^{\mathrm{a}}$ Revisão, o Capítulo 2400 na $5^{\text {a }}$ edição do MPEP, tratando basicamente das regras sobre o depósito de material biológico e requisitos em relação às sequências de nucleotídeos e aminoácidos.

\footnotetext{
${ }^{244}$ Para maiores informações a respeito do PCR, vide Capítulo 2.2.3.

${ }^{245}$ Em seguida, foram concedidas patentes sobre diversos animais transgênicos, como galinhas (US5656479), vacas (US5750176), cachorros (US6498791), porcos (US6498285), coelhos (US5675063), macacos (US5489524) e ovelhas (US5763739).
} 
Em 1995, na esteira das revisões realizadas em 1993, a USPTO editou as Utility Examination Guidelines, tratando principalmente da área biotecnológica. Nesta oportunidade, o USPTO esclareceu que o requisito da "utilidade" seria atestado se tivesse credibilidade ou, caso não a possuísse, se fosse bem estabelecida.

O resultado desta interpretação foi um ambiente mais livre para a concessão de patentes biotecnológicas, o que foi algo de diversas críticas e controvérsias e acabou por gerar uma nova revisão no ano de 1999. Por meio desta revisão, o USPTO buscou estabelecer dois testes para se verificar a utilidade: o primeiro, de acordo com os standards de 1995, se a invenção tiver uma "utilidade bem estabelecida"; e o segundo, se a invenção tem uma utilidade específica, substancial e com credibilidade (não bastando apenas a credibilidade, como previsto nos standards de 1995).

Neste ínterim, no ano de 1998, o USPTO concedeu patente sobre células-tronco embrionárias de primatas (incluindo, portanto, humanos) ${ }^{246}$. Esta patente foi seguida de uma segunda, limitada às células-tronco humanas, concedida em $2001^{247}$. O estudo das células tronco é de grande interesse em razão de sua possibilidade de se desenvolver de formas distintas, podendo originar quaisquer tecidos ou órgãos, de modo que o domínio e manipulação genética poderiam ser de grande importância médica.

Há diversos questionamentos a respeito da amplitude de referidas patentes, em especial a primeira delas, cuja reivindicação reside na preparação de células embrionárias de primatas purificadas que é capaz de: (a) se desenvolver em cultura in vitro por mais de 1 ano, (b) manter um cariótipo em que as características cromossômicas das espécies primatas estão presentes e não são alteradas substancialmente por meio de uma cultura prolongada, (c) manter seu potencial de se diferenciar em derivados de tecidos endodérmicos, mesodérmicos e ectodérmicos durante a cultura, e (d) não se diferenciar quando cultivados por meio camadas alimentadores de fibroblastos.

Mostra-se realmente amplo, especialmente por não apresentar qualquer função ou utilidade prática distinta daquela que se verifica no desenvolvimento natural das células-

\footnotetext{
${ }^{246}$ Patente US5843780, USPTO.

${ }^{247}$ Patente US6200806, USPTO.
} 
tronco dentro do organismo. Tais patentes (juntamente com uma terceira, a patente 7029913, concedida pelo USPTO em 18 de abril de 2006) formam o monopólio ${ }^{248}$ de exploração das células-tronco nos Estados Unidos pelo Wisconsin Alumni Research Foundation (WARF), organização associada à Universidade de Wisconsin.

No ano 2000, o USPTO concedeu patente sobre o gene humano relativo aos cânceres de ovário e de mama BRCA1 (Patent US6162897) e BRCA2 (Patent US5837492), que são o foco central de uma das mais importantes discussões judiciais sobre o tema, e será oportunamente discutida em Capítulo específico deste trabalho.

Até o início do ano 2000, o USPTO entendia que o material genético humano isolado por si só teria caraterísticas diferentes da forma encontrada nos seres humanos e, portanto, poderia ser considerado patenteável. Apesar de possuir uma estrutura idêntica àquela do material encontrado na natureza, ele seria resultado de um processo técnico que a natureza não seria capaz de reproduzir sozinha.

De acordo com este entendimento, a simples "descoberta" de uma determinada sequência de genes seria passível de proteção patentária e, por conseguinte, impossibilitaria a exploração do EST correspondente por qualquer outra pessoa sem a permissão do detentor de tal direito de propriedade. Tal entendimento poderia inviabilizar a realização de pesquisas de base que darão origens a novos medicamentos e tratamentos, pois o custo das pesquisas subsequentes seria extremamente elevado, situação esta que poderia trazer ineficiências de mercado, prejudicando tanto o detentor da patente quanto os seus usuários.

Por essa razão, o USPTO publicou em 2001 as Utility Examination Guidelines Comments and Responses, contemplando propostas de revisões para as diretrizes que norteavam a concessão de patentes sobre sequências de DNA desacompanhadas de sequer ao menos uma função biológica que possam por elas ser desempenhadas. Assim, muito embora fosse reconhecido à época que as moléculas de DNA que tenham a mesma

\footnotetext{
${ }^{248}$ Por força de referida patente, o WARF tem o poder de impedir que quaisquer terceiros explorem economicamente tais patentes nos EUA.
} 
sequência daquelas que ocorrem naturalmente são patenteáveis ${ }^{249}$, seja porque o DNA em sua forma pura não ocorre isolado na natureza, seja porque a forma sintética difere estruturalmente do componente natural, a sua simples descrição/identificação não seria suficiente para se garantir o seu patenteamento ${ }^{250}$.

Daquele momento em diante, as concessões dessas patentes passaram a ser submetidas a uma análise mais criteriosa, envolvendo a verificação dos cumprimentos de utilidade e descrição das patentes, que passou a exigir do inventor a especificação, de forma mais articulada e pormenorizada, do uso da invenção - em substituição às mais antigas e amplas reivindicações, que cobriam grande variedade de usos, indistintamente.

A análise do padrão de utilidade nos pedidos de patentes de ESTs passou então a rejeitar reivindicações amplas associadas a genes e proteínas por 2 motivos, basicamente: (a) um fragmento de DNA não é útil como probe ${ }^{251}$ para um gene sem que seja especificada a sua finalidade/motivo pelo qual este fragmento de DNA está sendo buscado; e (b) não pode ser utilizado para o isolamento de proteínas sem que seja especificado o uso da proteína "no mundo real".

Para se satisfazer a todos os elementos de patenteabilidade, o inventor deverá descrever ao menos um uso para a invenção, bem como demonstrar que ela é nova, não óbvia e suficientemente descrita de forma a permitir a sua reprodução sem qualquer necessidade de experimentação.

\footnotetext{
249 "A patent claim directed to an isolated and purified DNA molecule could cover, e.g., a gene excised from a natural chromosome or a synthesized DNA molecule. An isolated and purified DNA molecule that has the same sequence as a naturally occurring gene is eligible for a patent because (1) an excised gene is eligible for a patent as a composition of matter or as an article of manufacture because that DNA molecule does not occur in that isolated form in nature, or (2) synthetic DNA preparations are eligible for patents because their purified state is different from the naturally occurring compound." (http://www.gpo.gov/fdsys/pkg/FR-200101-05/html/01-322.htm)

${ }^{250}$ Comentário 3: "Thus, the intent of Congress with regard to patent eligibility for chemical compounds has already been determined: DNA compounds having naturally occurring sequences are eligible for patenting when isolated from their natural state and purified, and when the application meets the statutory criteria for patentability. The genetic sequence data represented by strings of the letters $A, T, C$ and $G$ alone is raw, fundamental sequence data, i.e., nonfunctional descriptive information. While descriptive sequence information alone is not patentable subject matter, a new and useful purified and isolated DNA compound described by the sequence is eligible for patenting, subject to satisfying the other criteria for patentability" (http://www.uspto.gov/web/offices/com/sol/og/2001/week05/patutil.htm).

${ }^{251}$ O termo "probe" designa a utilização de uma sequência complementar de DNA como uma espécie de sonda utilizada para identificar e marcar genes específicos que se pretende determinar.
} 
E assim o entendimento do USPTO evoluiu: até então era considerado patenteável um gene, ou outra molécula biológica natural, que tivesse sido isolado dos tecidos naturais e possuísse utilidade industrial; porém, o requisito da utilidade passou a assumir uma maior importância na análise e concessão de patentes relativas a genes, devendo as respectivas reivindicações ser especificadas de forma mais articulada e pormenorizada, em substituição às mais antigas e amplas reivindicações, que cobriam grande variedade de usos.

A patente nestes casos deve ser conferida, segundo o USPTO, se houver pelo menos uma utilidade específica (specific), substancial (substantial) e com credibilidade (credible) ou, alternativamente, se houver uma utilidade bem estabelecida - salienta-se que a utilidade do DNA objeto do pedido não necessariamente depende da função do produto codificado no gene.

Finalmente, no ano de 2014, a USPTO editou o Guidance for Determining Subject Matter Eligibility of Claims Reciting or Involving Laws of Nature, Natural Phenomena \& Natural Products ${ }^{252}$, tendo em vista as decisões da Suprema Corte nos casos Myriad e Mayo v. Prometheus, que em virtude de sua importância para o tema aqui tratado são analisados de forma mais pormenorizada neste trabalho.

Este "guia" estabelece critérios para se determinar a diferenciação entre o objeto da patente reivindicada daquele objeto que ocorre naturalmente - ou seja, se há algo significativamente diferente -, tornando a análise mais criteriosa. Estas diretrizes devem ser aplicadas a todas e quaisquer reivindicações de patentes que de qualquer forma envolvam produtos da natureza, leis da natureza ou fenômenos naturais - porém, não ideias abstratas -, a fim de auxiliar no exame da novidade de tais objetos que se pretendem a proteção patentária.

De acordo com tais diretrizes, primeiramente deve ser identificado se existe alguma exceção legal à patenteabilidade do objeto pretendido (a saber, ideias abstratas, leis da natureza, fenômenos naturais e produtos naturais).

${ }^{252}$ Cf. íntegra de tais diretrizes em http://www.uspto.gov/patents/law/exam/myriad-mayo_guidance.pdf. 
Verificando-se a ocorrência desta hipótese (ou havendo dúvidas a respeito, o que envolverá necessariamente reivindicações que estejam acompanhados dos termos "isolados", "recombinantes", sintéticos" e afins), deve então o examinador identificar se haverá algo substancialmente distinto em relação à simples ocorrência de tais situações espontâneas, o que deve ser feito de acordo com determinadas regras - haja vista o seu alto grau de subjetividade.

Para tanto, o USPTO esclarece que a conclusão pela existência ou não de algo significativamente diferente em relação a produtos ou princípios naturais deve ser baseada em análise que envolverá múltiplos aspectos, estabelecendo fatores (não exaustivos) que deverão apontar para a patenteabilidade do objeto reivindicado.

E, assim, os fatores que deverão pesar em favor da elegibilidade, por demonstrar a existência de um objeto significativamente diferente, são os seguintes:

(a) A reivindicação de produto menciona algo que inicialmente aparenta ser de ocorrência natural, porém após análise verifica-se não ser reproduzível espontaneamente e a sua estrutura física se mostra substancialmente diferente em relação àquela similar verificada em ambiente natural;

(b) A reivindicação adiciona ao objeto, que originalmente se enquadrava nas limitações legais, determinados passos ou elementos adicionais de forma a delimitar de forma clara e objetiva o objeto da proteção patentária, não impedindo terceiros de utilizar tais produtos e processos naturalmente ocorrentes;

(c) A reivindicação indica passos ou elementos adicionais que sejam centrais, importantes e significantes em relação ao objeto que originalmente se enquadra nas limitações legais, de modo suficiente a configurar uma exceção à exceção;

(d) A reivindicação indica passos ou elementos adicionais que sejam mais do que sua mera descrição, acompanhada de instruções gerais/genéricas relacionadas às possíveis formas de uso ou aplicação; 
(e) A reivindicação indica passos ou elementos adicionais à exceção legal, que envolvem utilização de determinada máquina ou resultam na transformação de determinada matéria ou substância que alterem seu estado, por meio da qual referida máquina/transformação implementa um ou mais elementos e/ou processos naturais ou os integram a uma aplicação que possua aplicação prática ou uso específico e diferente;

(f) A reivindicação indica passos ou elementos adicionais à exceção legal que adicionam uma característica não convencional, óbvia ou rotineira em seu respectivo campo de aplicação.

Assim, se o conjunto de fatores favoráveis à elegibilidade do objeto ao qual se busca proteção patentária não apontar para uma marcante diferença em relação a produtos e processos da natureza, tais diretrizes recomendam a rejeição preliminar da reivindicação apresentada, nos termos da nova redação dada ao parágrafo 7.05.13, com fulcro na seção 35, título 101, do USC.

\subsubsection{Evolução jurisprudencial americana em matéria de proteção biotecnológica}

Ao contrário da realidade brasileira, cujo ambiente jurídico envolvendo a matéria ainda se mostra pouco evoluído, o histórico jurisprudencial americano a respeito do tema é bastante rico, tendo amadurecido bastante no último século.

Diversas são as discussões judiciais reivindicando direitos proprietários sobre invenções biotecnológicas, inclusive sequências de DNA humano. Antigamente, as cortes americanas entendiam que os materiais puros necessariamente diferenciam-se dos materiais menos puros e impuros e, se os últimos forem os únicos existentes e disponíveis como padrão de referência, então, os materiais puros seriam novos e relação a estes. E tal entendimento fundamentou por anos a concessão de genes humanos reivindicados de forma simples e desacompanhada da descrição de qualquer aplicação útil.

Houve, contudo, uma grande evolução no entendimento jurisprudencial americano acerca da matéria. Abaixo segue uma análise dos antecedentes jurisprudenciais mais 
relevantes ao tema objeto do presente estudo, por fornecerem instrumentos e mecanismos de interpretação interessantes e capazes de subsidiar aspectos relevantes das conclusões deste estudo.

\subsubsection{Ex parte Latimer (Dec. Comm'r Pat.)}

As decisões emanadas pelas cortes americanas a respeito da proteção biotecnológica remontam a cases datados desde o ano de 1889. Nesta oportunidade, é interessante mencionar a discussão travada em Ex parte Latimer, por meio do qual o requerimento de patente sobre o núcleo fibroso de um pinheiro foi negado pela Comissão de Patentes (Comissioner of Patents) em 12 de março daquele ano.

Neste caso, entendeu-se que um produto da natureza (a fibra de um pinheiro) obtido por um processo novo a que se conferiu patente, ainda que valioso e útil, não deve ser considerado uma invenção patenteável. Isso se deve ao fato de que o produto não teria sido afetado, mudado ou alterado pelo processo - a invenção reside no processo e não no produto, que é natural. A fibra, com todas as suas características, é um produto da natureza e não do processo que a retirou da folha.

A fibra resultante do processo de extração não se torna algo novo ou diferente de sua estrutura natural, de modo que a invenção se encontra apenas no referido processo de obtenção da fibra isoladamente.

Entendeu-se que a fibra não seria nova por já existir na natureza, e por se tratar de um produto da natureza não poderia ser objeto de patentes em seu estado natural, ainda que isolado do ambiente em que normalmente ocorre, e como tal foi considerada matéria não patenteável (unpatentable subject matter).

\subsubsection{Parke-Davis v. Mulford}

Foi apenas em 1906 que se verificou a concessão da primeira patente sobre um produto de origem humana: a forma purificada de adrenalina. 
No ano de 1911, no Caso Parke-Davis v. Mulford (C.C.S.D.N.Y.), tal patente foi questionada quando o titular buscou penalizar sua utilização indevida. Nesta ocasião, o magistrado Learned Hand concluiu que produtos da natureza, isolados ou purificados, que tenham utilidade poderiam ser patenteados ${ }^{253}$. Isso se deveria ao fato de que tal procedimento levaria à existência de um novo produto, e não obstante inexistiria regra que excluiria tais produtos do patenteamento.

O ponto interessante na seara biotecnológica é que a decisão considerou patenteável um produto natural purificado e isolado (a adrenalina), criando uma exceção à não patenteabilidade dos produtos da natureza. Justificativa disso é verificação de uma distinção não só em grau, mas também na qualidade do produto isolado - além disso, justifica ainda que a mera extração de um produto natural, sem que houvesse qualquer mudança marcante originada desta intervenção humana, não deveria determinar não patenteabilidade, por inexistência de norma legal proibitiva expressa. Permite-se, assim, a proteção sobre produtos que ocorrem naturalmente e que não foram inventados pelo homem.

O entendimento exarado pelo magistrado Learned Hand nesta oportunidade foi contra a anterior jurisprudência que estabelecia a não patenteabilidade de produtos naturais que não fossem diferentes dos produtos encontrados na natureza, a exemplo de Ex parte Latimer (acima mencionado), e veio a ser muito criticada posteriormente - principalmente pelas implicações futuras no campo da biotecnologia, quando foi retomada no caso Merck\&Co. v. Olin Mathieson Chemical Corp (a seguir discutida), que reconheceu a vitamina B12 como um composto patenteável.

\subsubsection{American Fruit Growers, Inc. v. Brogdex Co}

Mais adiante, em 02 de março de 1931, a Suprema Corte Americana julgou o caso American Fruit Growers, Inc. v. Brogdex Co, por meio do qual se entendeu que produtos da natureza não poderiam constituir matéria patenteável se não houver uma mudança que resulte em criação de um produto fundamentalmente novo.

${ }^{253}$ Circuit Court, S.D., New York, em 28 de Abril de 1911. 
Este caso discutia a patente relacionada ao processo de preparar frutas com uma solução de borato de sódio, mineral que possui propriedades fungicidas. As frutas resultantes deste processo de preparação - cujas cascas estavam impregnadas com pequenas quantidades dessa substância - não demonstrava a existência de um novo processo e, portanto, o produto encontrava-se fora dos limites da lei patentária.

A simples imersão da laranja em uma solução não configura uma manufatura ou resulta em um artigo manufaturado, no sentido da lei de patentes. Dessa forma, continua a laranja sendo um produto natural - não havendo mudança no nome, aparência ou caráter geral da fruta. Deve haver uma transformação - um novo e diferente artigo precisa surgir, com nome, caráter ou uso distinto -, para que haja uma invenção patenteável, o que não ocorreu neste caso.

\subsubsection{Funk Brothers Seed Co. v. Kalo Inoculant Co.}

Neste mesmo sentido, no ano de 1948, a Suprema Corte também decidiu o caso Funk Brothers Seed Co. v. Kalo Inoculant Co. não garantindo proteção patentária a uma mistura de bactérias que resultou na potencialização de seus efeitos, por entender que não haveria distinção suficiente em relação ao que ocorria naturalmente.

A patente sobre esta cultura de bactérias, relacionadas a plantas leguminosas, foi considerada inválida, por ter-se entendido, à época, que a mera descoberta de que espécies de bactérias podiam ser misturadas sem que houvesse efeitos nocivos às propriedades de cada uma delas não é patenteável.

Isso porque se trata de uma mera descoberta de um fenômeno da natureza. Não houve uma invenção nos termos das leis patentárias, mas sim a mera manifestação de um fenômeno natural. Seria possível uma invenção apenas quanto à aplicação da lei da natureza a um fim novo e útil, o que não ocorrera no caso em análise. 


\subsubsection{Merck\&Co. v. Olin Mathieson Chemical Corp.}

Em 03 de março de 1958, o United States Court of Appeals - Fourth Circuit, ao julgar o caso Merck\&Co. v. Olin Mathieson Chemical Corp. tratou da patenteabilidade da vitamina B12. Nesta oportunidade, a vitamina B12 foi considerada patenteável por ter sido identificada a inexistência do produto na natureza na mesma forma em que foi produzida por meio da intervenção humana.

A vitamina B12 foi considerada nova e útil pelo tribunal americano, tendo em vista que o processo aplicado transformou um composto natural sem utilidade em um produto com grande valor médico e comercial. Uma vez caracterizada como composição nova e útil, distinta do produto anterior, entendeu-se ser passível de proteção patentária.

Deste modo, mesmo em se tratando de um produto da natureza, restou esclarecido que se forem preenchidos os requisitos de patenteabilidade, o composto deve ter sua patente concedida.

Retomou-se, nesse ponto, o argumento do magistrado Learned Hand, no caso Parke-Davis v. Mulford, segundo o qual foi sustentado que na verificação de distinção de qualidade (e não só de quantidade), seria possível o patenteamento - e, ainda que haja apenas a purificação do composto naturalmente ocorrente sem mudanças, não haveria restrição legal ao seu patenteamento.

\subsubsection{Diamond v. Chakrabarty}

No início dos anos 1980, no caso Diamond v. Chakrabarty, discutiu-se se um organismo vivo poderia ser excluído da possibilidade de patenteamento pelo simples fato de que estaria vivo, ainda que cumprisse os requisitos de patenteabilidade. Entretanto, a Suprema Corte Americana decidiu que a distinção relevante não se daria no âmbito de objetos vivos ou inanimados, mas sim na análise a respeito de se tratar o objeto de um produto da natureza - vivo ou não - e criações humanas. 
A Suprema Corte entendeu nesta ocasião que organismos vivos criados pelo homem (criações humanas, em oposição a produtos da natureza), por meio de engenharia genética, são patenteáveis. Assegurou-se assim a patente sobre uma bactéria, criada por engenharia genética, que é capaz de quebrar/digerir moléculas de petróleo em derramamentos, uma propriedade que nenhuma outra bactéria existente possui, outorgando-se, assim, a primeira patente sobre um organismo vivo criado.

O USPTO originalmente negou sua concessão em âmbito administrativo com base no argumento de que organismos vivos não seriam uma matéria patenteável (patentable subject matter). Entretanto, a bactéria criada não se enquadrava nos fenômenos naturais, mas sim no grupo das manufaturas e composições que não ocorrem naturalmente - é um produto do engenho humano, tendo nome, caráter e uso distintos ${ }^{254}$.

Referida decisão descreveu a matéria patenteável como “anything under sun made by man", mas na jurisprudência fica claro que fenômenos naturais, processos mentais e conceitos intelectuais abstratos não são patenteáveis. Foi a partir dessa decisão que houve grande crescimento na concessão de patentes em biotecnologia.

\subsubsection{Ex parte Allen}

Em 03 de Abril de 1987, o Board of Patent Appeals and Inferences analisou o caso Ex parte Allen e reverteu-se a rejeição de patentes sobre ostras desenvolvidas por engenharia genética, por não haver qualquer evidência de que referidas ostras ocorriam naturalmente, sem a interferência humana.

Discutiu-se neste caso a rejeição de patente a ostras geneticamente modificadas pelo USPTO, que entendeu se tratar de matéria que ocorreria naturalmente e de modo

\footnotetext{
254 "The key discovery in Chakrabarty's research was that "plasmids" control the oil degradation abilities of certain bacteria. Plasmids are transmittable, non-nuclear segments of DNA. Chakrabarty developed a process by which multiple plasmids capable of degrading different hydrocarbon components could be incorporated within a particularly "hardy" single bacterium. This genetically engineered bacterium was capable of breaking down oil spills at a much faster rate than naturally occurring bacteria. As importantly, it was not affected by varying environmental conditions" (ROBINSON, Douglas; MEDLOCK, Nina. Diamond v. Chakrabarty: A Retrospective on 25 Years of Biotech Patents. Intellectual Property \& Technology Law Journal, Vol. 17, N. 10. Out. 2005, p. 12).
} 
óbvio, sendo este o fundamento para rejeição do pedido de patente (não atendimento do requisito de não obviedade).

No entanto, rejeitou-se o argumento de que se tratava de matéria que ocorre naturalmente, reforçando a possibilidade de patenteamento de organismos vivos.

Em seguida, o USPTO editou uma declaração de que organismos multicelulares vivos não humanos, que não tenham ocorrência natural, incluindo animais, são matéria patenteável de acordo com o 35 USC 101 e de que a decisão no caso Ex parte Allen não afeta esse princípio ${ }^{255}$.

\subsubsection{Moore v. Regents of the University of California}

Em 9 de Julho de 1990, a Supreme Court of California julgou o caso Moore v. Regents of the University of California, no qual um paciente (Moore) reivindicou a propriedade de uma linha celular, usada para pesquisa sobre o câncer, desenvolvida por pesquisadores da Universidade da Califórnia a partir de suas células.

As células de um paciente, portador de um tipo incomum de leucemia, foram utilizadas por médicos da Universidade da Califórnia em pesquisas genéticas, e não apenas para o tratamento médico - houve o desenvolvimento de uma linhagem de células a partir daquelas que haviam sido extraídas do paciente, que foi patenteada pelos médicos (a patente tinha como objeto a linhagem de células e os produtos dela derivados).

Entendeu-se neste caso que não houve "apropriação indébita" (conversion), pois o paciente não tinha a propriedade ou a posse sobre suas células, sendo reconhecido que, uma vez dissociados do corpo humano, os tecidos e os genes deixam de pertencer à pessoa que os gerou.

\footnotetext{
255 "Shortly after the Allen decision, the Commissioner of Patents and Trademarks issued a notice (Animals Patentability, 1077 O.G. 24, April 21, 1987) that the Patent and Trademark Office would now consider nonnaturally occurring, non-human multicellular living organisms, including animals, to be patentable subject matter within the scope of 35 U.S.C. 101." (EUA. USPTO. 2105 - Patentable Subject Matter — Living Subject Matter [R-08.2012]. Capítulo 2100 do MPEP. Disponível em: http://www.uspto.gov/web/offices/pac/mpep/s2105.html. Acesso em: 27/10/2014)
} 
A justificativa está no fato de que a matéria objeto da patente sequer poderia ser propriedade de alguém, além da limitação do interesse do paciente em células retiradas. No entanto, houve a condenação do médico por não cumprimento de suas obrigações de divulgação, por não ter comunicado que possuía interesses outros além dos terapêuticos.

\subsubsection{Amgen, Inc. v. Chugai Pharmaceutical Co.}

No ano de 1991, foi decidido pelo United States Court of Appeals, Federal Circuit no Amgen, Inc. v. Chugai Pharmaceutical Co. que a patente sobre uma sequência de DNA isolado e purificado (que consistia basicamente em uma sequência de DNA codificador de um proteína - eritropoietina) era válida e, portanto, passível de ser infringida (a infração da patente era o objeto principal da lide).

As patentes em questão tinham como objeto a proteína eritropoietina, bem como o método de se purificar a eritropoietina humana - discutiu-se apenas a patente sobre o produto, ou seja, sobre a proteína. Ao final, concluiu-se que a patente, que se constituía basicamente em uma sequência de DNA codificador de um proteína, era válida.

\subsubsection{Mayo v. Prometheus}

Em 2012, a Suprema Corte Americana tratou da questão da patenteabilidade dos métodos diagnósticos e terapêuticos; trata-se do caso Mayo v. Prometheus. Em referida discussão, entendeu-se que o mero sequenciamento de genes se resume a coleta de dados, o que não é central para fundamentar tais reivindicações de patentes.

O caso Mayo v. Prometheus é importante, pois considerou que simples métodos diagnósticos não poderiam ser patenteados, sendo necessário mais do que simples coleta, análise e comparação de dados para que um método ou produto genético seja reconhecido como patenteável. Apesar de leis da natureza, fenômenos naturais e ideias abstratas não serem patenteáveis, uma aplicação da lei da natureza a uma estrutura ou processo pode merecer proteção patentária - para tanto, deve haver a limitação a uma aplicação particular e inventiva da lei. 
No caso, os processos sobre os quais há reivindicação de patente representam as descobertas que identificam, com precisão, as correlações entre níveis metabólicos e possíveis efeitos danosos ou ineficácia. Os processos envolvem: (a) etapa de administração (instrução do médico a administrar o remédio); (b) etapa de determinação (medida dos níveis metabólicos resultantes); (c) etapa de descrição das concentrações metabólicas acima das quais há probabilidade de efeitos colaterais prejudiciais e abaixo das quais é provável que haja ineficiência do medicamento).

Mayo utilizava os métodos diagnósticos acima, patenteados por Prometheus. Contudo, no ano de 2004, Mayo anunciou o desenvolvimento e exploração de seu próprio método diagnóstico e, por tal motivo, veio a ser processado por Prometheus por infração de sua patente.

A District Court considerou referidos métodos não patenteáveis, por tratarem de leis da natureza ou fenômenos naturais - a correlação entre os níveis metabólicos de tiopurina e a toxicidade e eficácia do medicamento. Muito embora o District Court tenha considerado que o teste desenvolvido por Mayo infringiria a patente sobre os processos acima, em que Prometheus figurava como única titular, entendeu em julgamento sumário que o objeto das patentes tratava de leis naturais ou fenômenos naturais (correlação entre os níveis de tiopurina e a toxicidade ou eficácia das dosagens) e, portanto, não era patenteável.

Em apelação, o Federal Circuit reformou a sentença, uma vez que os processos incluíam as etapas de administração e determinação de níveis, que tratam de uma transformação no corpo humano, passando no teste machine-or-transformation ${ }^{256}$. Fundamentou sua decisão com base nos seguintes argumentos:

(a) Não sendo as leis da natureza patenteáveis, os processos apenas podem ser patenteáveis se tiverem elementos adicionais que garantam que os processos são aplicações

\footnotetext{
${ }^{256} \mathrm{O}$ teste machine-or-transformation refere-se a método pelo qual uma reivindicação de patente é submetida para que sejam aferidas evidências acerca de sua patenteabilidade. Referido teste busca verificar se a invenção foi implementada por meio de modo não trivial e não convencional, ou se ela transforma uma matéria de um estado para outro (física ou quimicamente). Muito embora a jurisprudência americana já tenha estabelecido que a utilização deste teste não deva ocorrer de forma única exclusiva, ele vem sendo um importante instrumento para se apontar pela patenteabilidade de patentes biotecnológicas que vêm sendo reivindicadas.
} 
genuínas das leis, e não esquemas para monopolizar as correlações. Os três passos dos processos (acima descritos) nada adicionam às leis da natureza.

(b) Apesar da recompensa com patentes àqueles que descobrem leis da natureza potencialmente encorajar sua descoberta, a proteção patentária ampla e irrestrita pode inibir inovações futuras, principalmente quando o processo patenteado não é nada além de uma instrução geral de aplicação da lei natural, uma vez que leis e princípios são as ferramentas básicas do trabalho científico e tecnológico.

O caso foi então levado à apreciação da Suprema Corte Americana. Segundo a Corte, haveria a importante exceção jurisprudencial à regra do patenteamento relativa às leis da natureza, fenômenos naturais e ideias abstratas, que não são patenteáveis. Essas descobertas são manifestações da natureza, livres a todos os homens e reservadas a nenhum deles (citando Chakrabaty, em que se faz também referência ao caso Funk Brothers), sendo as ferramentas básicas aos trabalhos tecnológicos e científicos ${ }^{257}$.

Essa exclusão, contudo, se interpretada muito amplamente, poderia levar à mitigação da força e objetivos buscados pela lei de patentes, já que todas as invenções, em alguma medida, se relacionam a leis da natureza, fenômenos naturais e ideias abstratas. Por esse motivo, o fato de a invenção simplesmente conter um desses elementos não é suficiente para determinar sua impossibilidade de patenteamento, pois a aplicação, nova e útil, de uma lei da natureza ou de uma fórmula matemática pode merecer a proteção patentária.

As patentes têm como objeto as descobertas das correlações entre níveis metabólicos dos pacientes e sua efetividade e produção de efeitos colaterais. Os processos incluem a administração do remédio e determinação da concentração no organismo, com subsequente análise dos resultados.

\footnotetext{
${ }^{257}$ Trata-se de questão de extrema relevância por referir-se à patente como mecanismo de fomento à inovação (bio)tecnológica, assunto tratado mais detidamente no Capítulo 2.3. Por um lado, a proteção patentária na biotecnologia se mostra importante para se promover investimentos em pesquisas e desenvolvimento; de outro, amplas regras de patenteabilidade pode eventualmente limitar o desenvolvimento tecnológico por resultar em um grande número de direitos de exclusividade sobre o uso de dados científicos essenciais, que devem permanecer amplamente disponíveis.
} 
Os processos em questão aplicam leis naturais na descrição de relações entre a concentração metabólica de tiopurina e a possibilidade de que a dosagem ministrada seja ineficiente ou induza efeitos colaterais nocivos. Conclui-se disso que os processos não transformaram as leis naturais em aplicações patenteáveis dessas leis, sendo, portanto, não patenteáveis. Além disso, a proteção da patente poderia dificultar o uso das leis naturais subjacentes, inibindo seu uso em futuras descobertas. Entendeu-se, assim, que as patentes simplesmente descrevem a relação que estabelece uma lei natural.

O processo, para ser patenteável, deve ter características adicionais que garantam que não é um mero esforço para monopolizar a lei da natureza em si. E as 3 etapas adicionais descritas, embora não sejam leis naturais, envolvem atividades bem conhecidas, rotineiras e convencionais e, portanto, não são suficientes para transformar a natureza do pedido - apenas determinam a coleta de dados que permitem uma inferência acerca de correlações, sendo que o conjunto não adiciona nada de relevante em relação às etapas separadas. A este respeito, transcrevemos o seguinte trecho de tal decisão:

"Although "laws of nature, natural phenomena, and abstract ideas" are not patentable subject matter under $\$ 101$ of the Patent Act, Diamond v. Diehr, 450 U. S. 175, 185, "an application of a law of nature... to a known structure or process may [deserve] patent protection," id., at 187. But to transform an unpatentable law of nature into a patent-eligible application of such a law, a patent must do more than simply state the law of nature while adding the words “apply it." See, e.g., Gottschalk v. Benson, 409 U. S. 63, 71-72. It must limit its reach to a particular, inventive application of the law. (...)

Because the laws of nature recited by Prometheus' patent claims - the relationships between concentrations of certain metabolites in the blood and the likelihood that a thiopurine drug dosage will prove ineffective or cause harmare not themselves patentable, the claimed processes are not patentable unless they have additional features that provide practical assurance that the processes are genuine applications of those laws rather than drafting efforts designed to monopolize the correlations. (...)

This Court has repeatedly emphasized a concern that patent law not inhibit future discovery by improperly tying up the use of laws of nature and the like. See, e.g., Benson, 409 U. S., at 67, 68. Rewarding with patents those who discover laws of nature might encourage their discovery. But because those laws 
and principles are 'the basic tools of scientific and technological work', id., at 67, there is a danger that granting patents that tie up their use will inhibit future innovation, a danger that becomes acute when a patented process is no more than a general instruction to 'apply the natural law', or otherwise forecloses more future invention than the underlying discovery could reasonably justify",258 (grifo nosso)

Atividades convencionais ou óbvias não são normalmente suficientes para transformar uma lei da natureza não patenteável em uma aplicação patenteável dessa lei. São dois os principais casos que reforçam a conclusão pela não patenteabilidade: Diamond v. Diehr, 450 U.S. 175 (1981) e Parker v. Flook, 437 U.S. 584 (1978).

O caso Diehr tratava de um método de moldagem de borracha bruta em outros produtos, usando uma equação matemática conhecida para determinar o momento de abertura da prensa. O processo inclui as etapas de monitoramento, alimentação de um computador com os números resultantes e configuração do computador para que, no momento apropriado, acione o mecanismo para abrir a prensa. O processo foi considerado patenteável por se considerar a existência de etapas adicionais integradas à equação que não eram óbvias, já em uso ou convencionais. Houve a transformação do processo em uma aplicação inventiva da fórmula.

A discussão travada em Flook referia-se a um método para ajustar limites em conversões catalisadas de hidrocarbonetos, incluindo as etapas de mensuração dos níveis das variáveis, uso de um algoritmo matemático para o cálculo dos limites e ajuste do sistema para refletir os novos limites de alarme. Não foi considerado patenteável, por não acrescentar nada de relevante à fórmula matemática - não havia nenhum conceito inventivo na aplicação da fórmula reivindicada.

O processo apresentado no caso Mayo v. Prometheus é assemelhado ao processo do caso Flook, por não acrescentar nada de específico às leis da natureza além de atividade bem conhecida, rotineira e convencional. Outros casos também corroboram o entendimento de que apenas etapas convencionais anexas, especificadas em um alto nível de generalidade, não torna leis da natureza, fenômenos naturais e ideias patenteáveis.

\footnotetext{
${ }^{258}$ Supreme Court of the United States. Mayo v. Prometheus, julgado em 20/03/2012. Disponível em: http://www.supremecourt.gov/opinions/11pdf/10-1150.pdf. Acesso em:?
} 
Há, na decisão da Suprema Corte, constante menção à preocupação de que a lei patentária não iniba futuras descobertas ao dificultar o uso futuro de leis da natureza, uma vez que essas leis e princípios são as ferramentas básicas do trabalho científico e tecnológico. E considerando-se que as etapas adicionais dos processos não acrescentam de modo significante às leis naturais em si, não se restringindo a aplicações particulares destas, reforça-se a conclusão pelo não patenteamento dos processos.

Outro argumento considerado foi a possibilidade de patenteamento de um processo englobando leis da natureza específicas e de abrangência restrita. Haveria, assim, uma distinção das leis da natureza com base na interferência que se poderia verificar nas inovações em outros campos, no presente ou futuro. Contudo, entendeu-se que mesmo uma lei da natureza limitada poderia inibir pesquisas futuras - na jurisprudência, não se distinguem as leis da natureza de acordo com sua amplitude (o que se interpretou claramente foi a proibição do patenteamento de leis da natureza, fórmulas matemáticas e assemelhados).

Por tais motivos, concluiu-se que os pedidos de patente em questão reivindicam as leis da natureza em si, sendo, portanto, consideradas inválidas.

\subsubsection{Association for Molecular Pathology v. Myriad Genetics}

Por fim, no dia 13 de junho de 2013, a Suprema Corte Americana decidiu o caso Association for Molecular Pathology v. Myriad Genetics, entendendo que os genes humanos isolados e purificados não seriam patenteáveis; contudo, reconheceu pela possibilidade de se patentear as sequências de cDNA sintetizadas em laboratório, em razão da criação humana envolvida e por não existirem na natureza.

Trata-se acirrada disputa de patentes por determinadas sequências isoladas do DNA humano, mais especificamente a respeito da possibilidade de se patentear: (a) os genes isolados contendo sequências inteiras ou porções dos genes BRCA-1 e BRCA-2; e (b) métodos de comparação e análise das sequências genéticas para identificar a presença de 
mutações correlacionadas à predisposição a câncer de mama ou de ovário, a partir de tais genes isolados.

As mutações nos genes BRCA se correlacionam ao aumento do risco de cânceres de ovário e de mama. Mulheres com as mutações no BRCA têm um risco de 50\%-80\% de desenvolver câncer de mama e de 20\%-50\% de desenvolver câncer de ovário. Dessa forma, o teste diagnóstico é um importante instrumento para os cuidados clínicos quanto aos cânceres supramencionados - podendo ser um fator a ser considerado na análise acerca de medidas profiláticas, inclusive cirúrgicas ${ }^{259}$, bem como auxiliando a estruturação de um tratamento apropriado.

Estudos científicos identificaram a base genética dos cânceres relacionados aos genes BRCA-1 e BRCA-2 por meio da análise positional cloning. A análise baseia-se em um banco de amostras de DNA de famílias em que se verificou a hereditariedade do câncer, correlacionando a ocorrência deste com certas sequências de DNA, permitindo a identificação da localização dos genes BRCA no genoma humano, o seu isolamento e a determinação de sua sequência de nucleotídeos.

A Myriad depositou pedidos de patente pela primeira vez em 1994, tendo como objeto o gene BRCA-1 isolado e métodos diagnósticos associados. A primeira patente foi concedida em 1997. O primeiro depósito quanto ao gene BRCA-2 e métodos diagnósticos associados ocorreu em 1995 - e a primeira concessão, em 1998.

A Myriad, em 1998, tornou disponível a algumas instituições a licença colaborativa, embora limitasse os testes que poderiam ser realizados. Também declarou publicamente que, por possuir os direitos de patente sobre os genes BRCA e métodos para detectar mutações, todos que realizassem testes à época deveriam interrompê-los, até que se acordasse a licença. Contudo, foi estabelecida a exceção quanto aos testes realizados com o propósito de programas de pesquisa não comerciais, nos quais não se poderia fornecer o resultado ao paciente nem receber remuneração deste. Assim, a Myriad tornou-

\footnotetext{
${ }^{259}$ Caso da atriz americana Angelina Jolie, que optou por realizar cirurgia de remoção dos seios após ter sido diagnosticado que teria predisposição para desenvolvimento de câncer de mama. ("Breast cancer test 'Angelina Jolie effect' found", BBC, 19/09/2014. Disponível em: http://www.bbc.com/news/health29251765. Acesso em: 18/12/2014).
} 
se o único prestador de tais testes nos EUA e ajuizou diversas ações judiciais por infrações às suas patentes.

À luz de tal situação a American Civil Liberties Union Foundation e a Association for Molecular Pathology ajuizaram demanda judicial contra Myriad Genetics e a Universidade de Utah (na qualidade de depositantes de tal pedido de patente), e o USPTO, com o objetivo buscar o reconhecimento de nulidade de referidas patentes.

Tal requerimento baseia-se no princípio de que o DNA representa a corporificação física de informação biológica e seu isolamento não alteraria essa qualidade fundamental nem as informações nele codificadas - dessa forma, não se poderiam conceder patentes sobre sequências de DNA encontradas na natureza. Além disso, a comparação das sequências de DNA não seria patenteável por se tratar de um processo mental abstrato, que também é matéria não patenteável (35 USC §101).

As 7 patentes que integram o objeto da lide em questão (objeto de 15 reivindicações) podem ser alocadas em 2 tipos: (a) patentes de produtos; e (b) patentes de processos e métodos.

Alguns dos pedidos de patente dizem respeito a múltiplas sequências de DNA que são relativas a uma proteína (em decorrência da multiplicidade de códons que podem se relacionar a um mesmo aminoácido) e outros dizem respeito a uma sequência específica. Há também os que se referem a pequenos fragmentos ou mutações. Dessa forma, os pedidos de patentes de produtos são muito amplos, atingindo qualquer DNA BRCA-1 e BRCA-2 isolado.

Há também patentes de processo, em geral tratando da análise de sequência de DNA em comparação com certas mutações específicas - ou seja, tratam da comparação de sequências genéticas. 


\subsection{Decisão de $1^{a}$ instância}

Para delimitar a parte da decisão que interessa ao presente estudo, a corte de $1^{\text {a }}$ instância partiu da análise da aplicabilidade e escopo da seção 101, do título 35, do USC, ao caso sub judice.

Com base nessas premissas daí obtidas, desenvolveu-se toda a fundamentação jurídica para justificar a invalidade das reivindicações das patentes de produto e de processos pela Myriads, e concedidas pelo USPTO. É o que se passa a analisar em seguida.

\subsection{Reivindicações de produto são inválidas}

Uma primeira divergência importante analisada pela corte de $1^{\mathrm{a}}$ instância reside na definição de DNA para fins de enquadramento no conceito de matéria patenteável ou não, tema central do presente estudo.

A este respeito, os autores entendem o DNA ser uma sequência de ácidos nucleicos, constituindo uma sequência de nucleotídeos ou um poli nucleotídeo, caracterizada pelo seu conteúdo informacional.

A Myriad, por sua vez, define DNA como uma molécula real e tangível, uma composição química de ácido desoxirribonucleico e base de fósforo - ou seja, DNA não seria a mera informação: o DNA se refere a uma manifestação física do ácido desoxirribonucleico - ou seja, é um componente químico tangível.

Já o DNA isolado é definido pelos autores como um fragmento de DNA substancialmente separado de outros componentes celulares e outros fragmentos de DNA. A Myriad novamente rejeita essa definição, que levaria ao equivocado entendimento de que os fragmentos existem livremente na célula, separadamente dos demais componentes; entretanto, o DNA isolado seria uma molécula substancialmente separada de outros componentes celulares que naturalmente acompanha a sequência humana, incluindo DNAs isolados recombinantes ou clonados, bem como análogos sintetizados quimicamente ou biologicamente por sistemas heterólogos. O DNA isolado, portanto, se referiria a um 
segmento de nucleotídeos existente em separado de outros componentes celulares normalmente associados a DNA, incluindo proteínas e outras sequências de DNA no remanescente do genoma.

A análise acerca da patenteabilidade do DNA pela District Court se deu com base em uma verificação preliminar da seção 101 do título 35, USC, a partir da qual se entende que deve haver determinação sobre os seguintes aspectos: (a) se a invenção reivindicada é dotada de utilidade e (b) se a invenção reivindicada constitui matéria patenteável ou se recai sobre a exceção judicialmente criada de "produtos da natureza" - leis da natureza, fenômenos naturais e ideias abstratas.

Os princípios científicos e leis da natureza, mesmo que pela primeira vez descobertos, têm existência perene, não devendo ser objeto de direitos patentários. A descoberta de lei da natureza não é um invento que permite a proteção (Parker v. Flook, 437 U. S. 1978), sendo certo que fenômenos da natureza, processos mentais e conceitos abstratos são ferramentas básicas de trabalho científico e tecnológico, não sendo patenteáveis (Gottschalk v. Benson, 409 U.S. 1972).

A razão de existência desta exclusão, segundo defende a corte de primeira instância, reside no fato de que, por vezes, a excessiva proteção patentária pode impedir o progresso científico ${ }^{260}$. Deste modo, a determinação do tipo de descoberta que se pretende patentear deve preceder à avaliação a respeito de sua novidade e não-obviedade, que se encontram nas seções 102 e 103 do título 35, do USC - diferindo estes, portanto, do requisito de patenteabilidade do produto ou processo que está previsto na seção 101 .

A este respeito, esta decisão recorda que a Suprema Corte já estabeleceu em outras oportunidades que produtos da natureza não constituem matéria patenteável se não houver uma mudança que resulte na criação de um produto fundamentalmente novo ${ }^{261}$. A Suprema Corte neste mesmo sentido já decidiu também que uma mistura de bactérias não constituiria matéria patenteável, como já descrito no caso Funk Brothers.

\footnotetext{
${ }^{260}$ A este respeito, refere-se ao caso Lab. Corp. of Am. Holdings v. Metabolite Labs., Inc., 548 U.S. 2006.

${ }^{261}$ American Fruit Growers 283 U.S.: "there must be transformation; a new and different article must emerge having a distinctive name, character, or use" (Anheuser-Busch Brewing Ass'n v. United States, 207 U.S. 1908).
} 
Da mesma forma, a Suprema Corte, ao analisar a aplicação da seção 101 USC no caso Diamond v. Chakbarty, considerou patenteável uma bactéria criada por entender que seria notadamente diferente de qualquer outra encontrada na natureza. Esse requisito de características notadamente diferentes, quanto à seção 101, significa que a invenção deve ter forma, qualidade ou propriedade nova ou distintiva; ou seja, a mera purificação de materiais conhecidos não resultaria em um produto patenteável ${ }^{262}$.

Neste contexto, discute-se a patenteabilidade ou não de matéria originada da purificação de componentes que ocorrem naturalmente e não existem na natureza em sua forma pura, sendo trazida pela Myriad o entendimento do magistrado Learned Hand no caso Parke-Davis \& Co. v. H.K. Mulford Co., 189 F.2d 95 S.D.N.Y. 1911, que - em tese estabeleceria que a purificação de um componente natural, por si só, possibilitaria a patenteabilidade. Contudo, a questão, nesse caso, era relativa à novidade (regulamentada pelo parágrafo 102) e não à patenteabilidade da matéria (objeto do parágrafo 101). O outro precedente discutido em tal decisão foi o caso Merck \& Co., Inc. v. Olin Mathieson Chem. Corp., 253 F.2d 156, em que se considerou pela possibilidade de patenteamento da composição da vitamina B12, por ser esta mais que uma mera purificação de um produto conhecido. Em outras palavras: para que algo derivado de um produto da natureza seja patenteável, deve possuir forma, qualidade ou propriedade nova ou distintiva.

Dessa forma, entende o órgão julgador que a purificação de um produto não o transforma em matéria patenteável - é preciso que o produto purificado possua características marcadamente distintas para que se caracterizem os requisitos da seção 101 . Sob este prisma, a questão controversa apresentada diz respeito à existência ou não de características marcadamente distintas no DNA isolado reivindicado pela Myriad, em relação a um produto da natureza. E, segundo a decisão ora em análise, nenhuma das diferenças apontadas pela Myriad seria hábil para estabelecer a patenteabilidade dos genes BRCA-1 e BRCA-2.

\footnotetext{
${ }^{262}$ In re Merz, 97 F.2d C.C.P.A - Court of Customs and Patent Appeals - 1935; The American Wood-Paper Co. v. The Fibre Disintegrating Co., 90 U.S. 1874: "A process to obtain it from a subject from which it has never been taken may be the creature of invention, but the thing itself when obtained cannot be called a new manufacture"; Cochrane v. Badische Anilin \& Soda Fabrik, 111 U.S. 1884; In re Marden, 47 F.2d C.C.P.A. 1931.
} 
A premissa básica do argumento da Myriad foi no sentido de que as moléculas de DNA isoladas não devem ser tratadas de forma diferente em relação a outros componentes químicos e que a diferença nas propriedades estruturais e funcionais do DNA isolado o tornam uma matéria patenteável. Contudo, segundo sugere esta decisão, o argumento em questão não leva em conta as características específicas do DNA: além de molécula, é também um carreador de informações (sendo essas informações a codificação de proteínas), tornando-o muito diferente de outras moléculas.

$\mathrm{O}$ argumento de que todos os compostos químicos carregam informações ignora o fato de que as informações do DNA são as únicas que dizem respeito à síntese de outras moléculas no corpo (as proteínas). O DNA, nesse sentido, seria uma corporificação das leis da natureza que regem o funcionamento do corpo humano. Dessa forma, a comparação com outros compostos químicos que foram objeto de patentes não substitui a discussão sobre as características distintivas do DNA.

Tendo em vista as qualidades únicas do DNA, chega-se à conclusão de que não há diferenças marcantes entre o DNA isolado e o DNA nativo, dada a importância da sequência de nucleotídeos para as funções em ambos os casos. A preservação dessa característica fundamental (codificação de proteínas pela sequência de nucleotídeos) levou ao entendimento exarado pelas cortes inferiores de que o DNA isolado se tratava de produto da natureza não patenteável.

A respeito da alegação da Myriad no sentido de que a análise da seção 101 deve levar em conta apenas as diferenças entre o DNA nativo e isolado, e não as similaridades existentes entre os dois (por exemplo, as mesmas sequências codificadoras de proteínas), também foi refutada.

Nenhum dos argumentos da Myriad estabelece a natureza distinta do DNA reclamado, segundo a decisão exarada em $1^{a}$ instância. $O$ argumento de que a associação de proteínas com DNA nativo estabeleceria uma diferença quanto ao DNA isolado parte de uma comparação incorreta entre DNA isolado e cromatina - que são diferentes, uma vez que a cromatina inclui proteínas normalmente associadas ao DNA. A comparação correta deve se dar entre DNA isolado e o DNA nativo correspondente, sendo que ambos não incluem proteínas. 
$\mathrm{O}$ argumento da Myriad de que as diferenças funcionais entre o DNA nativo e isolado fazem com que sejam marcadamente diferentes baseia-se no fato de que o DNA isolado pode ser aplicado em situações em que o DNA nativo é imprestável, em especial testes diagnósticos, processos biotecnológicos e tratamentos médicos. Assim, a utilidade do DNA isolado como um padrão advém de sua habilidade de identificar e interagir com outras moléculas de DNA, ou seja, de se ligar a uma sequência específica de DNA.

No entanto, essa utilidade decorre do fato de que o DNA isolado possui uma sequência de nucleotídeos idêntica à sequência buscada, ou seja, refere-se à identidade entre o DNA nativo e isolado. Dessa forma, a utilidade do DNA isolado depende da preservação da sequência de nucleotídeos do DNA nativo - que também é a premissa dos testes genéticos da Myriad. Se as sequências BRCA-1 e BRCA-2 fossem significativamente diferentes de alguma forma, o sentido de seu uso (produção de proteínas BRCA1/2) seria mitigado.

A purificação do DNA nativo não altera sua característica essencial, ou seja, sua sequência de nucleotídeos, definida pela natureza e essencial para sua função biológica e sua utilidade em laboratórios. A necessidade do isolamento diz respeito apenas a uma limitação tecnológica quanto ao uso do DNA, permanecendo a sequência de nucleotídeos como a característica definidora do DNA isolado que permite seu uso nas diversas aplicações citadas pela Myriad.

Neste aspecto, a corte entende que as patentes relativas ao DNA isolado BRCA-1 e BRCA-2 comporta uma comparação com a mistura de bactérias do caso Funk Brothers 33 U.S. A mistura não pode ser patenteada, pois se entendeu que a "invenção" foi uma descoberta de que algumas bactérias podem ser misturadas sem efeitos prejudiciais às propriedades de cada uma - ou seja, descobriu-se a qualidade de não inibição.

A identificação de segmentos específicos dos cromossomos 13 e 17, relacionados com os cânceres de mama e de ovário, seguida pelo isolamento dessas sequências de outro DNA genômico e componentes celulares, como no caso Funk Brothers, foi uma descoberta de fenômeno da natureza (ou seja, o efeito natural de certas mutações em um segmento particular do genoma humano). O isolamento, por sua vez, é a simples aplicação de técnicas bem conhecidas por todos os técnicos da área. 
Com relação ao fato de que no DNA nativo há íntrons que não se verificam no caso dos genes BRCA-1 e BRCA-2 sintetizados em laboratórios (cDNA), sustentou a corte que o simples fato de não conterem os introns não faz com que as moléculas de cDNA de BRCA-1 e BRCA-2 sejam marcadamente diferentes dos nativos - as variantes representadas por esses cDNAs são resultados naturais da formação do mRNA. Assim, as sequências contidas no DNA em questão são idênticas às encontradas no DNA nativo e resultado de fenômenos naturais.

A identificação das sequências dos genes BRCA-1 e BRCA-2 é uma grande realização científica, mas isso não significa que seja algo suscetível de proteção patentária. Por não ser marcadamente diferente do DNA nativo existente na natureza, o DNA isolado constitui uma matéria não patenteável, de acordo com o título 35, seção 101, do USC.

\subsection{Reivindicações de método são inválidas}

Apesar de não serem patenteáveis os fenômenos da natureza, os processos intelectuais e os conceitos abstratos, a aplicação de uma lei da natureza ou de uma fórmula matemática a uma estrutura ou processo pode ser objeto de patente.

No caso Bilski v. Kappos, 130 S. Ct. 3218 , 3225 (2010), definiu-se um teste para se analisar se um processo incorpora apenas uma aplicação particular do princípio ou se representa o princípio em si, denominado machine or transformation. Um processo é patenteável, pela seção 101, se: (a) vincula-se a uma máquina ou equipamento; ou (b) transforma um artigo em particular em outra coisa ou estado, sendo a transformação crucial ao objetivo do processo em questão. Muito embora se trate de um teste válido, reconheceu-se que ele não é suficiente para determinar a patenteabilidade em casos desta natureza.

Os processos de análise e comparação das sequências de DNA em questão, quanto à identificação de mutações nos genes BRCA-1 e BRCA-2, não se limitam a um método particular nem delimitam as atividades de análise; da mesma forma, para os processos de comparação visando a identificar possíveis diferenças, não se especificam quaisquer limitações no método utilizado. 
Para a Myriad, não se tratariam de processos intelectuais, pois incorporam uma etapa de transformação, encaixando-se no segundo critério da seção 101, acima mencionado. Para isso, baseia-se no precedente de Prometheus, no qual se discutiu a patente sobre métodos de calibração da dosagem devida de determinado medicamento para desordens gastrointestinais, por meio da medida de metabólitos (uma vez que os níveis destes se relacionam à eficiência de uma certa dose de remédio).

Como já acima analisado, os depositantes neste caso reivindicavam patente sobre os referidos métodos de aperfeiçoar a eficiência terapêutica e minimizar os efeitos colaterais, por meio da determinação dos níveis de metabólitos e da identificação de necessidades de ajustes nas dosagens. Como a sentença de $2^{\mathrm{a}}$ instância neste caso considerou que haveria etapa de transformação (de determinação dos níveis, que não era meramente de inspeção e envolvia uma transformação), entendeu-se que o teste machine or transformation teria sido satisfeito. E assim como o ato de determinação dos níveis de metabólitos foi considerado patenteável, a Myriad alegou que também o mesmo critério deveria ser aplicado à análise e comparação das sequências dos genes BRCA-1 e BRCA-2, que incluem etapas de transformação física (o isolamento e sequenciamento de DNA), que são centrais ao objetivo dos processos.

No entanto, ao analisar a similaridade do caso Prometheus para eventual aplicação, o juízo de primeira instância entendeu que a determinação dos níveis de metabólitos foi considerada transformadora, pois envolvia a extração e mensuração de concentrações - o que não deve ser considerado como mera determinação dos níveis. Além do mais, esta decisão da $2^{\mathrm{a}}$ instância foi reformada pela Suprema Corte Americana, sendo tais patentes de processos invalidadas.

Não obstante, entendeu-se que os métodos em questão na presente demanda direcionam-se somente aos processos intelectuais abstratos de análise e comparação das sequências dos genes - o que não seria suficiente para assegurar a sua patenteabilidade, mesmo em vista da alegação da Myriad no sentido de que se comparam moléculas de DNA e não sequências de DNA, o que faria incluir uma etapa transformadora central no processo (isolamento e sequenciamento de DNA). 
Foi ainda trazido à discussão o caso Grams Fed. Cir., em que se discutiu a patente sobre um método de diagnóstico de condições anormais em um indivíduo, sendo considerada inválida pelo fato de que a essência do que estava sendo pedido era um algoritmo matemático para analisar dados clínicos e que o processo físico (teste laboratorial) era apenas para obter dados clínicos. Os processos relativos ao BRCA-1 e BRCA-2 apresentam uma situação análoga, uma vez que a essência do pedido de patente é a identificação de predisposição ao câncer de mama com base na análise e comparação de tais sequências de genes. Isso representaria apenas uma etapa de coleta de dados para se obter a informação da sequência de DNA sobre a qual se realizam a análise e a comparação.

Além disso, não há qualquer especificação do método para o isolamento e sequenciamento de DNA e, assim, ainda que incluíssem transformações físicas, não passariam no teste machine or transformation quanto à patenteabilidade.

Uma das patentes em discussão diz respeito à comparação das taxas de crescimento das células na presença e ausência de uma potencial terapia para o câncer. Por meio da utilização de um gene BRCA-1 alterado, o efeito do tratamento é medido com base nas taxas de crescimento. Esse processo tem etapas transformadoras, mas sua essência diz respeito a um ato de comparação do crescimento das células, sendo, na verdade, um método científico, relacionado ao princípio científico de que uma taxa de crescimento menor significa que o componente pode ser uma terapia para o câncer.

Tendo em vista todos os aspectos tratados, foi decidido em primeira instância que os processos de análise e comparação de sequências de DNA seriam inválidos.

\subsection{Sentença de $1^{a}$ instância: conclusões}

No caso em análise, inexistia controvérsia acerca da utilidade dos produtos e métodos e, portanto, a principal tarefa do juízo de primeira recaía sobre a análise a respeito de se tratar o DNA isolado contendo sequências que ocorrem naturalmente matéria patenteável, ou se deveria ele ser encaixado na exceção legal dos produtos da natureza. 
Assim, no que tange às patentes de produto, entendeu-se que as moléculas de DNA isolado se enquadram na exceção de produtos da natureza, por não serem marcadamente diferentes do DNA nativo. Sob este aspecto, a decisão se baseou no fato de que DNA é a corporificação física de informação, que é essencial para sua utilidade enquanto ferramenta molecular.

Quanto às patentes de processo, por meio da aplicação do teste "machine-ortransformation" foram tais reivindicações consideradas não patenteáveis. Entendeu-se que os pedidos de patentes cobririam a análise e comparação de sequências de DNA por qualquer método, tratando, pois, de processos mentais independentes de quaisquer transformações físicas.

A Corte ainda salientou, alternativamente, que, mesmo se a análise considerasse que os processos incluíam transformações associadas ao isolamento e sequenciamento do DNA humano, essas transformações não seriam nada mais que etapas preparatórias de coleta de dados. Por fim, a Corte entendeu que o processo de comparar a taxa de crescimento das células trataria de um princípio científico básico, sendo as etapas transformativas apenas coletas de dados preparatórias.

\subsection{Reforma da Decisão de Primeira Instância}

Tendo em vista a decisão favorável à nulidade das patentes, a Myriad e os diretores da Universidade da Utah Research Foundation apelaram da decisão da corte distrital, sobre a validade de suas patentes.

E, em 29 de julho de 2011, o Tribunal do Distrito Sul de Nova York ${ }^{263}$ decidiu em $^{2}$ favor da indústria farmacêutica. Referido acórdão reformou parcialmente a decisão obtida em primeira instância, por maioria de votos. Abaixo são analisados os principais aspectos tratados e argumentos mais relevantes à reforma da decisão de primeira instância, acima discutida.

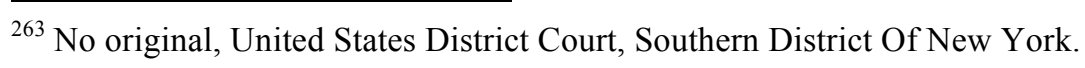




\subsection{Conceito de matérias patenteáveis}

Segundo entendimento do tribunal, fundamentado em antecedentes da Suprema Corte Americana, o título 35, seção 101, USC, deve ser interpretado amplamente, dado o termo "any" que existe no dispositivo (devendo-se dar largo escopo às leis patentárias). No entanto, ainda que amplo, referido texto legal não é ilimitado, havendo 3 exceções criadas judicialmente: leis da natureza, fenômenos físicos e ideias abstratas.

Também se incluem nessas exceções os fenômenos da natureza, processos mentais e produtos da natureza, sendo relevante a distinção do $§ 101$ entre produtos da natureza e invenções humanas, de modo que a matéria incluída nessas exceções deve ser parte do repositório de conhecimento de toda a humanidade, livre para todos os homens e reservado exclusivamente a nenhum.

\subsection{Reivindicações de moléculas de DNA isoladas}

De acordo com a Myriad, a corte distrital teria chegado à conclusão de que as moléculas de DNA isolado não seriam patenteáveis por: (a) não ter aplicado corretamente o precedente da Suprema Corte que exclui a patenteabilidade de todos os produtos da natureza, exceto os marcadamente diferentes das formas naturais; e (b) ter focado incorretamente não nas diferenças entre o DNA isolado e o DNA nativo, mas sim na similaridade entre eles (seu conteúdo informacional).

Para a Myriad, uma molécula de DNA isolado seria patenteável por ser uma composition of matter que não ocorre naturalmente, com nome, caráter e uso distintivos o DNA isolado não existe na natureza e pode ser usado como padrão e prova em diagnósticos de câncer, ao contrário do DNA nativo. E, caso a exceção "produtos da natureza” seja categórica, todas as matérias serão, em algum nível, compostas de materiais naturais, indo contra os precedentes judiciais, o USPTO's 2001 Utility Examination Guidelines e o papel do Congresso em editar leis patentárias.

Os autores, por sua vez, afirmam que as patentes sobre moléculas de DNA isolado incluem fenômenos naturais e produtos da natureza. O produto da natureza não seria 
patenteável mesmo se tivesse passado por uma mudança altamente útil em sua forma natural; para que seja patenteável, deve ter um nome, caráter e uso distintos, fazendo-o marcadamente diferente em relação ao produto natural. Por manter a mesma sequência de nucleotídeos do DNA nativo, o DNA isolado não teria características marcadamente diferentes. Além disso, as patentes teriam o efeito de excluir qualquer pessoa da possibilidade de trabalhar com genes BRCA.

O governo, enquanto amicus curiae, não defende a posição adotada pelo USPTO à época, de que moléculas de DNA isolado são patenteáveis, sugerindo um "meio termo": as moléculas de DNA criadas pelo homem, tais como o cDNA, seriam patenteáveis porque não ocorrem na natureza, isoladas ou em sequências contíguas em um cromossomo. De outro lado, DNA genômico não modificado e isolado não seria patenteável, por se tratar de produto da natureza.

Neste contexto, propõe o teste do magic microscope: se um microscópio imaginário pudesse focalizar a molécula de DNA que se pretende patentear no corpo humano, tratarse-ia de matéria não patenteável. Dessa forma, os genes BRCA-1 e BRACA-2 não são patenteáveis, mas a sequência de cDNA seria, já que é sintetizada pelo homem, contendo apenas as sequências codificadoras não contíguas (éxons), que não podem ser identificadas na natureza.

Ao final, o Federal Circuit reconhece a validade dos argumentos trazidos pela Myriad e conclui que as patentes relativas a DNA isolado, limitadas ou não a cDNA, são patenteáveis pelo título 35, seção 101, do USC.

Ao lado disso, durante a revisão da decisão exarada em primeira instância, o tribunal buscou novamente amparo nas decisões da Suprema Corte relativas aos caos Chakrabarty e Funky Brothers, porquanto fornecem as bases para se decidir a respeito da patenteabilidade de moléculas de DNA isolado ${ }^{264}$.

\footnotetext{
${ }^{264}$ A bactéria desenvolvida por engenharia genética em Chakrabarty é comparada com as bactérias não patenteáveis de Funk Brothers, de acordo com o §101, pois, neste caso, apenas se descobriu que a associação de certas bactérias não levava à inibição mútua - por essa característica, essa cultura poderia se associar a uma gama maior de leguminosas. Considerou-se que esta fora uma descoberta de um work of nature, sendo que não se adquiriram novas propriedades ou usos, em oposição à bactéria em Chakrabarty, que teria características marcadamente diferentes.
} 
A distinção entre o que é um produto da natureza e uma invenção humana pelo $\S 101$ se dá em comparação ao que existe na natureza. Aplicando-se esse teste ao caso em questão, conclui-se que o DNA isolado é uma matéria patenteável por se tratar de moléculas marcadamente diferentes (identidade química e natureza distintivas) das que existem na natureza (ou seja, do DNA nativo).

Cada molécula de DNA é uma parte de uma estrutura mais complexa (cromossomo), em que a molécula de DNA se anexa a proteínas, formando uma estrutura denominada cromatina, ao passo que o DNA isolado seria uma porção livre de uma molécula de DNA nativo, tendo suas ligações covalentes quebradas ou sendo sintetizado para tanto. Dessa forma, a intervenção humana em clivar ou sintetizar fornece ao DNA isolado uma identidade química diversa da possuída pelo DNA nativo - há uma manipulação química para se produzir uma molécula marcadamente diferente.

Esse processo difere da simples purificação: nestes casos, um componente é purificado de uma mistura que o contém - o DNA isolado, ao contrário, não existe na natureza como uma mistura física a ser purificada. Na natureza, o DNA isolado está unido por ligações covalentes a outros materiais - ao se quebrarem essas ligações, não se obtém uma forma purificada de um produto natural, mas sim uma entidade química distinta. Além disso, o DNA isolado nem mesmo requer purificação, uma vez que pode ser sintetizado diretamente como moléculas isoladas.

E, tendo-se em vista que as ligações covalentes separam uma espécie química de outra, os autores/apelados alegam que pelo DNA isolado manter a mesma sequência de nucleotídeos do DNA nativo, ele não teria características marcadamente diferentes. Essa abordagem, segundo o tribunal, não se pautaria pela diferença marcante, mas sim pela similaridade existente, qual seja, o conteúdo de informação da sequência de nucleotídeos do DNA nativo e do DNA isolado.

Sob esta perspectiva, a corte distrital concluiu pela não patenteabilidade de moléculas de DNA isolado pelo fato de sua função genética ser transmitir informações. A Court of Appeals discorda dessa conclusão por ser a patenteabilidade determinada pela composição (composition of matter). 
Segundo o tribunal, o uso das substâncias químicas poderia ser relevante na análise da não obviedade dos produtos ou métodos que incorporem tais usos, mas isso não significa que a patenteabilidade do DNA isolado seja negada pelo simples fato de ter propriedades informacionais semelhantes a um material natural (DNA natural). O DNA isolado é distinto de sua existência natural enquanto porções de entidades maiores, sendo seu conteúdo informacional irrelevante para tanto.

Pela existência de estrutura química marcadamente diferente, em comparação com o DNA nativo, rejeita-se o "teste do microscópio mágico" proposto pelo governo, pois não leva em consideração a existência de moléculas como entidades químicas separadas. Esse teste poderia focalizar porções de qualquer molécula complexa, tornando-a não patenteável, ainda que essa porção nunca tenha existido enquanto molécula separada. Isso poderia desencorajar investimentos em inovações.

Durante o processo, sugeriu-se que a possibilidade de patenteabilidade de DNA isolado abriria portas a muitos outros pedidos de patentes, como elementos químicos, minerais, partículas atômicas, e até mesmo órgãos. No entanto, não se pode afirmar, no julgamento, se nestes casos há ou não uma composição marcadamente diferente da que existe na natureza. Pelo contrário, uma porção da molécula de DNA nativo (DNA isolado) tem uma natureza química marcadamente diferente do DNA nativo, sendo, portanto, patenteável - cria-se uma nova entidade química.

O Tribunal também refuta a alegação dos autores no sentido de que a amplitude de algumas patentes fundamentaria a rejeição da patenteabilidade, por entender que inexiste base que justifique rejeição ou invalidação por esse motivo.

Ademais, a decisão pela patenteabilidade de moléculas de DNA isolado é congruente à prática comum do USPTO, sendo que a Suprema Corte já entendeu que a mudança de práticas comuns deve ocorrer pelo Congresso, não pelos tribunais ${ }^{265}$. Nesse caso, o USPTO concedeu patentes para moléculas de DNA por cerca de 30 anos, sendo a primeira concedida na década de 1980 - o Congresso nunca indicou que a posição do

\footnotetext{
${ }^{265}$ No caso J.E.M. Ag Supply, Inc. v. Pioneer Hi-Bred International, Inc., entendeu-se que não se poderiam excluir plantas do escopo do §101 uma vez que o USPTO concedeu patentes sobre plantas por 16 anos e nunca foi sinalizado pelo Congresso ou agências especializadas, que isso seria inconsistente com a lei.
} 
USPTO seria inconsistente com o $§ 101$. Por tal motivo, a exclusão da patenteabilidade de genes deverá ocorrer por mudança legislativa.

\subsection{Reivindicações de processos}

Com relação aos processos, a Court of Appeals conclui que, à exceção de um, todos os demais deveriam ser invalidados por se tratarem de processos mentais abstratos, não passando no teste machine-or-transformation.

\subsubsection{2.3.1 Métodos para comparação ou análise de sequências}

A Myriad argumenta que seus métodos de comparação e análise de sequências BRCA satisfazem o teste machine or transformation, pois é necessária uma transformação: a extração e o sequenciamento das moléculas de DNA antes que estas sejam comparadas ou analisadas.

E, de acordo com a empresa, a corte distrital não teria reconhecido a natureza transformadora por (a) ter interpretado de forma incorreta o termo sequência como uma informação (e não como uma molécula); e (b) concluir, alternativamente, que as transformações seriam apenas etapas coletoras de dados, e não o cerne do processo.

Para os autores/apelados, esses processos correspondem à ideia abstrata de comparar sequências, englobando um fenômeno da natureza (correlação entre mutações genéticas e a predisposição ao câncer) - mesmo a limitação do processo a um campo específico (sequências do gene BRCA) é insuficiente para caracterizar a patenteabilidade.

Além disso, não se satisfaria o teste machine or tranformation por só se incluírem no processo a comparação e análise de sequências dos genes. E, muito embora o teste machine or transformation não seja o único para se determinar se uma invenção é patenteável pelo $\S 101$, os pedidos de patente relativos à análise e à comparação de duas sequências genéticas não se enquadrariam no escopo do $§ 101$ por se tratarem apenas de processos mentais abstratos. Logo, tais processos não seriam patenteáveis. 
A aplicação de uma fórmula ou ideia abstrata em um processo pode descrever uma matéria patenteável; contudo, a Myriad não aplica a comparação em um processo: a comparação é a completude do processo reivindicado. Para tentar se enquadrar nesta situação, a Myriad busca identificar etapas transformativas em seu processo: a extração de DNA de uma amostra e o sequenciamento da molécula do DNA BRCA, alegando que ambas as etapas necessariamente precedem a comparação.

Os pedidos de patente, contudo, não incluem essas etapas, dizendo respeito apenas à etapa de comparação e análise. A Myriad alega que comparar e analisar devem ter seu sentido obtido de acordo com as especificações da patente - nas especificações, "sequência" não se refere à informação e sim a uma molécula física de DNA, cuja sequência deve ser determinada previamente (ou seja, trata da sequência linear de bases de nucleotídeos).

Foi reconhecido pelo tribunal que os processos da Myriad não incluem uma etapa determinadora da sequência dos genes BRCA ou qualquer outra etapa transformativa. A comparação entre duas sequências trata da mera inspeção. Dessa forma, os métodos de comparar e analisar sequências de nucleotídeos não satisfazem o teste machine-ortransformation e são direcionados a processos mentais abstratos de comparação de duas sequências de nucleotídeos.

\subsection{2 Método terapêutico de triagem para predisposição a câncer}

Esse método se dá pelas mudanças nas taxas de crescimento das células. Como mencionado, os autores alegam se tratar de uma ideia abstrata de comparar a taxa de crescimento de dois grupos de células e de um princípio científico básico (que a menor taxa de crescimento na presença de um potencial componente terapêutico sugere que esse componente é uma terapia ao câncer).

O tribunal ao rever tal questão, pela aplicação do machine or transformation conclui que se incluem etapas transformativas no processo, a saber: (a) o crescimento das células transformadas com um gene BRCA-1 alterado, na presença ou ausência do 
potencial medicamento ao câncer; (b) a determinação da taxa de crescimento; e (c) a comparação das taxas de crescimento.

Depreende-se de tal análise que o método possui mais do que etapas abstratas de comparação, por incluir as etapas de crescimento celular (que envolve a manipulação de células e sua média de crescimento) e de determinação da taxa de crescimento, que também envolve manipulação física das células, sendo tais etapas centrais ao processo. Ademais, o processo não trata de um princípio científico, porque diz respeito apenas a específicas células transformadas por genes específicos e que crescem na presença ou ausência de um tipo determinado de medicamento.

Diante de tais argumentos, o tribunal considera que o método apresenta aplicações funcionais e palpáveis no campo da biotecnologia, julgando favoravelmente à possibilidade de sua proteção pela via patentária, nos termos do §101 da seção 35 do USC.

\subsection{Conclusões: Acórdão de $2^{\mathrm{a}}$ instância}

Ao cabo de tudo o quanto discutido em sede de apelação, e após confirmar a decisão da corte distrital de exercer jurisdição declaratória no caso em tela, o tribunal reverteu a decisão de que as patentes de produto da Myriad relativas às moléculas de DNA isolado enquadrar-se-iam nos produtos da natureza, sendo não-patenteáveis pelo 35 USC, por entender que essas moléculas não existem na natureza.

Reverte-se também a decisão relativa ao pedido de patente do método de analisar possíveis terapias contra o câncer pela mudança nas taxas de crescimento das células, que segundo decidido pelo juízo de $1^{\mathrm{a}}$ instância estaria relacionado a um princípio científico não patenteável. Contudo, mantém-se a decisão de que as patentes de método de comparação ou análise de sequências de DNA não são patenteáveis, pois não incluem etapas transformativas e cobrem apenas etapas mentais e abstratas, que não são patenteáveis.

Como mencionado, o acórdão foi decidido por maioria, sendo que os votos dos magistrados Lourie e Moore foram favoráveis à patenteabilidade dos genes, mas por razões 
diversas: este considerou não ser suficiente a diferença química entre DNA isolado e o DNA natural, mas levou em conta também o costume do USPTO de conferir essas patentes e os interesses legítimos (reliance interests) dos detentores das patentes; aquele, por sua vez, entende que o isolamento rompe as ligações entre as cadeias duplas que existem na molécula de DNA natural, sendo o DNA sintetizado apenas uma fração deste e uma molécula que não ocorre naturalmente, ainda que não haja mudança na característica do DNA de transmitir informações.

O magistrado Bryson, contudo, entende que o DNA isolado não é patenteável, por entender que a mera separação das cadeias é irrelevante e a sequência de nucleotídeos das moléculas em questão é a mesma da sequência de nucleotídeos nos genes humanos que ocorrem naturalmente.

Entretanto, todos os 3 magistrados concordaram que os pedidos de patente relativos ao cDNA preenchem os requisitos de patenteabilidade do $§ 101$, uma vez que deve ser criado em laboratório, já que os íntrons normalmente encontrados no gene nativo são removidos do segmento de cDNA.

A questão principal discutida foi se o ato de isolar o DNA (separar um gene específico ou uma sequência de nucleotídeos do restante do cromossomo) é uma atividade inventiva que enseja o direito de patente.

Houve grande divergência entre os juízes, inclusive na fundamentação das decisões. Tendo-se em vista tais divergências de opiniões existentes, mesmo entre aqueles que julgaram no mesmo sentido, passa-se em seguida a avaliar cada um dos argumentos trazidos à colação, a fim de enriquecer ainda mais o debate.

\subsection{Votos dos Magistrados}

\subsection{1 LOURIE e MOORE, Circuit Judges}

$\mathrm{O}$ votos dos magistrados Lourie e Moore são convergentes quanto à questão da patenteabilidade dos processos em questão, bem como quanto aos pedidos direcionados às 
sequências de cDNA isolado, concordando com o julgamento relativo às demais sequências.

Pelo 35 USC §101, requer-se que uma invenção seja nova e útil, dentre uma das quatro categorias: processo, máquina, manufatura ou produto. Apesar de o legislativo não ter inserido nenhuma outra limitação ao escopo do $\S 101$, os precedentes judiciais forneceram três exceções aos largos princípios de patenteabilidade do §101: leis da natureza, fenômenos físicos e ideias abstratas.

O magistrado Lourie não considerou ser suficiente a diferença química entre DNA isolado e o DNA natural, mas levou em conta também o costume do USPTO de conferir essas patentes e os interesses legítimos (reliance interests) dos detentores das patentes. Faz referência a cases para demonstrar como os tribunais americanos mostram uma postura flexível de análise de patente sobre o DNA isolado, que basicamente parte da verificação acerca da existência ou não de características marcadamente distintas com potencial de utilidade significativa.

E segue neste contexto dizendo que a análise seria relativamente fácil se a invenção existisse previamente na natureza, exatamente como consta no pedido de patente. No entanto, o simples fato de não existir exatamente como se descreve no pedido não significa, automaticamente, ser uma matéria patenteável.

Moore busca desenvolver alguns conceitos de caráter mais químico e biológico que considera importantes para a análise do caso, de forma a categorizar os pedidos de patente relativos ao DNA isolado da seguinte forma: (a) sequências idênticas a sequências que ocorrem naturalmente (tanto do gene inteiro quanto de frações menores); e (b) sequências que são diferentes das sequências genéticas naturais (incluindo cDNA).

As sequências de cDNA apresentam uma análise mais fácil, o que é compartilhado também por Lourie. Apesar de a corte distrital ter considerado que se enquadravam entre as leis da natureza, Moore considera tal entendimento incompatível com o fato de que essas sequências de cDNA simplesmente não existem na natureza. O cDNA é inspirado na natureza (uma vez que obtido a partir do RNA), mas tem uma sequência de nucleotídeos e estrutura química diversas. Dessa forma, o cDNA tem nome, caráter e uso distintos, com 
características marcadamente distintas do RNA e da sequência contínua de DNA encontrada no cromossomo. Logo, são criações humanas.

De outro lado, no entendimento de Moore, as sequências de DNA que têm a mesma sequência de bases de um gene natural, no todo ou em parte, representam um assunto de maior complexidade. Apesar de a diferente estrutura química sugerir que o DNA isolado não seja um produto da natureza, não se considera que essa diferença, sozinha, seja necessariamente suficiente para se caracterizar o DNA isolado de como marcadamente distinto do DNA cromossômico para que se tenha uma matéria patenteável.

As moléculas de DNA isolado são partes, com fins diferentes, do DNA natural, não sendo naturalmente produzidas sem a intervenção humana e, por tal motivo, imperioso se faz avalizar existência ou não de nova utilidade que faz com que sejam marcadamente distintas da natureza.

As pequenas sequências isoladas, de até 15 nucleotídeos, têm uma grande variedade de aplicações e usos que são novas e distintas, se comparadas com as sequências que ocorrem na natureza (por exemplo, podem ser usadas como padrão para identificar mutações em genes). A possibilidade de usar moléculas de DNA isolado como bases para testes diagnósticos genéticos é um claro aumento da sua gama de utilidades - essas novas possibilidades de aplicação se baseiam em propriedades físicas decorrentes da natureza, especialmente a de se ligar a uma cadeia complementar. $O$ teste diagnóstico, contudo, não é uma utilidade natural - assim, o DNA em questão não serve ao fim que tinha originalmente; pelo contrário, as sequências isoladas têm características marcadamente distintas, que são responsáveis por sua nova e significante utilidade.

A conclusão sobre a patenteabilidade do gene isolado depende do valor que se atribui à diferença de estruturas em comparação com a similaridade de funções. Caso não se analisasse o contexto, talvez se considerasse que o gene ou sua grande parte não seria patenteável, dada a não existência de uma nova utilidade, tendo o mesmo fim que na natureza (codificar uma proteína).

No entanto, esse caso tem que ser analisado com seu histórico. E, nesta esteira, avalia que o Congresso americano vem, por longos anos, autorizando um escopo 
expansivo das matérias patenteáveis. Dessa forma, o USPTO tem concedido patentes para sequências de DNA isoladas e, mais genericamente, para produtos naturais purificados. Além disso, deve-se evitar a expansão da exceção jurisprudencial às matérias patenteáveis, uma vez que se envolvem tanto expectativas quanto direitos de propriedade intelectual. Dessa forma, a patenteabilidade da totalidade do gene ou de sua grande parte é reconhecida.

Por tal motivo, as expectativas da indústria de biotecnologia também devem ser levadas em conta, pois há investimento significativo de tempo e dinheiro para a obtenção de direitos de propriedade intelectual relacionados às sequências de DNA. A não proteção das patentes destruiria as legítimas expectativas dos inventores que as $\operatorname{detêm}^{266}$, e a perturbação às expectativas da indústria biotecnológica pode levar ao impedimento - e não promoção - de inovação. A manutenção dessas expectativas é importante em razão do grande número de direitos de propriedade intelectual envolvidos - tanto DNA isolado quanto produtos naturais purificados em geral.

A indústria de biotecnologia está entre as mais inovadoras e as patentes sobre genes isolados, incluindo as patentes em questão, existiu por décadas sem qualquer evidência de efeitos nocivos na inovação. Mudar o curso das práticas depois de vários anos apenas servirá para punir as companhias que decidiram investir grandes quantidades de tempo e dinheiro na identificação, isolamento e caracterização de genes, afrontando as expectativas da indústria biotecnológica e impedindo o avanço das ciências e artes.

Não obstante seja essa política do USPTO antiga e recorrente, os EUA, como amicus curiae, postularam ser as diretrizes do USPTO incorretas e deturpadoras da lei, defendendo a aplicação do teste do microscópio na análise do $\S 101$, pelo qual se conclui pela não patenteabilidade. No entendimento de Moore, o uso de um "microscópio mágico" não permitiria a visualização das moléculas em questão no caso, uma vez que a molécula de DNA isolado tem diferentes ligações químicas em comparação com a sequência não isolada. Por mais que se possam ver os nucleotídeos no cromossomo, o fragmento de DNA isolado é uma molécula diferente.

\footnotetext{
${ }^{266}$ Sobre este assunto, vide Festo Corp. v. Shoketsu Kinzoku Kogyo Kabushiki Co., 535 U.S. 722, 739 (2002).
} 
Deste modo, considera que o novo teste proposto pelo governo muda mais de um século de precedentes e a prática do USPTO nas áreas farmacêutica e biotecnológica. Esse teste é meramente mecânico e não leva em conta a possibilidade de mudanças químicas nas sequências de DNA isolado, em comparação com seu estado natural, levarem a usos marcadamente diferentes. Esse teste colocaria em questão a validade de um número desconhecido de patentes e pedidos de patente.

Tal entendimento, por configurar uma possível negação da proteção patentária existente por anos, capaz de eliminar um grande número de direitos de propriedade intelectual, deveria ser aplicado por intermédio de uma mudança legislativa - e, por essa razão, a utilização da via do judiciário para tal manobra não seria aceitável, especialmente porque traz à tona questões de natureza ética e moral. Qualquer exceção à linguagem ampla do $§ 101$ deve ser aplicada com muito cuidado, tendo-se em vista a promoção das ciências e das artes.

Assim, até que o Congresso atue, os tribunais devem considerar a linguagem do $\S 101$ como ela se encontra - que, segundo seu entendimento, é ampla o suficiente para incluir as patentes sobre DNA isolado em questão, que no caso em tela deve ser considerada uma criação de novas moléculas de DNA, com novas características e utilidade nova, incluindo a possibilidade de ser usado como padrão em testes genéticos.

$\mathrm{Na}$ verdade, o Congresso, pelo menos implicitamente, aprovou a política do USPTO de conceder patentes sobre genes e DNA isolado. Por se tratar de uma discussão que deve ser feita no Congresso, não se estende a exceção de leis da natureza para incluir as sequências de DNA isolado.

\subsection{2 BRYSON, Circuit Judge}

Bryson concorda com o julgamento da corte no que tange à patenteabilidade dos pedidos de cDNA e à patenteabilidade dos pedidos de processo. No entanto, discorda quanto à decisão de que os pedidos relativos ao gene BRCA isolado seriam patenteáveis. Tratar-se-ia de matéria não patenteável, sendo que a decisão da corte teria consequências 
mais amplas, como a apropriação privada de métodos para o sequenciamento do genoma como um todo.

Em linhas gerais, a questão posta é se um indivíduo pode obter direitos patentários sobre um gene humano. O argumento da Myriad reside no fato de que não houve o patenteamento de um gene humano, mas algo bem diferente: um gene humano isolado, que difere do gene nativo porque o processo de extração resulta em mudanças em sua estrutura molecular (embora não altere o código genético). Dessa forma, deve-se decidir se um processo de isolamento do material genético a partir da molécula de DNA humano faz do material isolado uma invenção patenteável. A corte concluiu que sim; o magistrado Bryson, contudo, concluiu que não.

A Myriad não foi a primeira a mapear o gene BRCA em sua localização cromossômica (isso foi feito por uma equipe de pesquisadores liderados pela Dra. MaryClaire King) e também não inventou um novo método de sequenciamento de nucleotídeos. Pelo contrário, aplicou técnicas conhecidas para identificar a ordem dos nucleotídeos nos genes BRCA. A descoberta das sequências de DNA teve importante aplicação no combate ao câncer de mama - mas a descoberta de sequências é um fato não protegido (assim como a descoberta da localização no cromossomo).

Para Bryson, a Myriad pode patentear aplicações originadas da descoberta. No entanto, algumas das patentes da Myriad acabam por se apropriar de qualquer tentativa de sequenciar os genes BRCA, incluindo o sequenciamento do genoma como um todo. E assim conclui por sua não patenteabilidade, considerando que pode haver efeitos adversos na pesquisa e tratamento caso se considere pela patenteabilidade.

Em seu entendimento, há 3 categorias de pedidos de patente a serem analisados no âmbito desta demanda: (a) pedido que cobrem os genes BRCA isolados; (b) pedidos que cobrem apenas o cDNA BRCA; e (c) pedidos que cobrem porções dos genes BRCA e cDNA com apenas 15 nucleotídeos.

Relativamente aos genes BRCA isolados, Bryson considera que recairiam na matéria não patenteável, por entender que Myriad está reivindicando os próprios genes, 
que aparecem na natureza, nos cromossomos de seres humanos. A única mudança feita é a mudança necessariamente incidental à extração dos genes de seu ambiente natural.

Apesar de entender que o processo de extração pode ser patenteável, os genes isolados não são materialmente diferentes dos genes nativos. Os genes seriam análogos a um novo mineral descoberto ou a uma nova planta encontrada na natureza.

Os genes humanos podem ser dificilmente extraídos de seu ambiente natural e, como os minerais, podem ser usados com propósitos que seriam inatingíveis caso permanecessem em seu estado natural. O processo de extrair minerais ou plantas, assim como o processo de isolamento do material genético, pode resultar em mudanças físicas ou químicas à substância natural - mas isso não torna minerais ou plantas patenteáveis, sendo que o mesmo deve ocorrer no caso dos genes. A mera extração não intitula ao extrator o direito de patente sobre os produtos extraídos.

A maioria dos juízes considerou que a quebra das ligações químicas dos genes BRCA tornaria os genes isolados materiais diferentes. A ligação química, contudo, é uma mera força entre dois átomos ou um grupo de átomos forte o suficiente para que se torne conveniente analisar o agregado como uma espécie molecular independente.

Para se isolar o gene BRCA, é necessário quebrar ligações químicas que unem o gene em seu lugar no corpo, mas a sequência genética codificadora, que é o objeto dos pedidos sobre o gene BRCA, mantém-se a mesma, quer o gene esteja no corpo humano, quer esteja isolado. A maioria, contudo, não concorda que esses casos seriam análogos, entendendo que átomos isolados não são patenteáveis, mas moléculas isoladas o são.

A opinião majoritária do tribunal ao julgar este caso entendeu que deve haver deferência à prática do USPTO em conceder as patentes. No entanto, segundo Bryson, deve ser levado em consideração que à prática e às diretrizes do USPTO não deve ser conferido um peso significativo, pois este não tem competência legislativa quanto a assuntos como a patenteabilidade. Além disso, qualquer força que a posição do USPTO tenha tido no passado acabou sendo minada pela posição tomada pelo governo no caso. 
O Departamento de Justiça, em nome dos EUA, posicionou-se no sentido da não patenteabilidade dos pedidos da Myriad relativos a genes (exceto os relativos a cDNA). Como o Departamento de Justiça fala em nome do Executivo e o USPTO faz parte deste, é razoável assumir que o Executivo mudou sua posição em relação à tomada pelo USPTO em suas diretrizes de 2001 .

Os pedidos de patente de produto da Myriad não são definidos por uma fórmula química - dessa forma, cobrem uma grande gama de composições, inclusive variações moleculares ainda não descobertas e que não poderiam ser quimicamente descritas pela Myriad. Tais variações compartilhariam apenas a característica de codificar a mesma proteína que o gene BRCA naturalmente ocorrente. Pela perspectiva genética, a matéria do pedido (gene BRCA) é idêntico ao gene BRCA natural, tendo a mesma sequência, codificando as mesmas proteínas e representando as mesmas unidades de hereditariedade.

A única diferença é que o DNA isolado foi isolado de acordo com os limites predefinidos pela natureza, nos pontos em que se preserva a capacidade do gene de expressar a proteína que é codificada. Dessa forma, extrair um gene seria como retirar uma folha de uma árvore.

A maioria considera que as porções codificadoras reivindicadas dos genes BRCA nativos são parte de uma molécula maior e que os genes isolados, por serem extraídos de outra molécula, são invenções humanas. Esse argumento, contudo, não seria sustentável, pois uma partícula subatômica seria, nesse sentido, patenteável, por ter sido parte de uma estrutura maior.

De outro lado, sugerir que algo isolado ou extraído de um ambiente natural sempre permanece um produto natural e, por isso, não patenteável, seria simplificar demais o problema, segundo o magistrado ${ }^{267}$. Casos envolvendo a purificação de uma substância natural também devem levar em conta uma análise semelhante - a mera purificação não enseja a patenteabilidade, a menos que resulte em uma mudança de funcionalidade (ou

\footnotetext{
${ }^{267}$ A esse respeito, utiliza como exemplo o desenvolvimento de um bastão de baseball, em que o resultado é um produto com uma função completamente diversa daquela que apresenta a matéria-prima, resultando em uma manufatura humana.
} 
seja, se dela resultar um produto com características que a tornem, para todos os fins práticos, uma nova coisa - comercial e terapeuticamente).

Ocorre que, segundo o entendimento do magistrado, no caso dos genes BRCA, a extração tem o objetivo de preservar a estrutura e a função que o gene possui no ambiente natural e, dessa forma, não resulta em uma invenção humana. As diferenças estruturais são irrelevantes à função dos genes e à sua utilidade na forma isolada; mais que isso, a Myriad não teria identificado novos usos para os genes BRCA isolados como padrões, sendo que a identidade de função do gene isolado é crucial para seu valor. O isolamento do material genético naturalmente ocorrente não torna patenteáveis os genes BRCA, porquanto não se verifica alteração suficiente exigida pelo standard estabelecido no caso Chakbaraty.

Por outro lado, concorda Bryson que o cDNA BRCA é patenteável, uma vez que não pode ser isolado da natureza, devendo ser sintetizado em laboratório. É uma invenção humana com estrutura distinta - pois os íntrons encontrados no DNA nativo são removidos do segmento de DNA. Além disso, o cDNA tem uma utilidade não compartilhada pelo DNA natural e pelo mRNA, já que pode ser inserido em uma célula não humana para produzir proteínas.

\subsection{A Decisão da Suprema Corte Americana}

Após essa reviravolta no caso, foi este então finalmente colocado à apreciação da Suprema Corte Americana. Em que pese se ter pretendido devolver à apreciação da Suprema Corte outras matérias já tratadas em instâncias inferiores, foi reconhecido que sua decisão seria limitada a responder unicamente à seguinte questão: seriam os genes humanos considerados matéria patenteável?

O caso requer que se resolva sobre a patenteabilidade de um segmento de DNA que ocorre naturalmente pelo 35 USC $§ 101$, em virtude de seu isolamento do restante do genoma humano. Também se analisa a patenteabilidade do cDNA, que contém as mesmas informações que codificam proteínas encontradas no DNA natural, mas que exclui os segmentos de DNA não codificadores. 
Para tanto, a Suprema Corte Americana, definiu que os seguintes pontos deveriam ser avaliados: (a) verificar se os pedidos de patente da Myriad dizem respeito a algo novo e útil ou fenômenos que ocorrem naturalmente; (b) avaliar subsunção ou não dos pedidos de patente à regra de exceção da natureza, para o qual o caso Diamond v. Chakrabarty se mostra de grande utilidade; (c) definir se o cDNA, por não ser considerado um produto da natureza, poderia ser patenteável pela análise do §101, não apresentando os mesmos obstáculos à patenteabilidade que os segmentos de DNA isolados e que ocorrem naturalmente; (d) o caso não envolveu pedidos de patentes de métodos, patentes de aplicações do conhecimento relativo aos genes ou a patenteabilidade de DNA cuja ordem de nucleotídeos tenha sido alterada.

A Corte reconheceu que a Myriad teria descoberto a localização precisa e a sequência típica dos genes BRCA-1 e BRCA-2, cujas mutações podem aumentar os riscos de cânceres de ovário e de mama, e que o conhecimento da sequência de nucleotídeos teria lhe permitido o desenvolvimento de testes médicos para detectar mutações nos genes e analisar os riscos de câncer. Muito embora essa tenha sido uma importante descoberta, não se atendem aos requisitos do $§ 101$. Os pedidos de patente focariam unicamente as informações genéticas que são codificadas nos genes em questão.

Um segmento natural de DNA é um produto da natureza e não pode ser patenteado apenas por ter sido isolado, mas o cDNA é patenteável por não ocorrer naturalmente, criando-se algo novo quando a sequência de íntrons é excluída e o cDNA é sintetizado em ambiente laboratorial.

A decisão final, é portanto, no sentido de que um segmento de DNA que ocorre naturalmente não é patenteável apenas por ter sido isolado, mas o cDNA é patenteável por não ocorrer naturalmente. Dessa forma, mantém-se em parte e reverte-se em parte a decisão da Court of Appeals. 


\subsection{Evolução legislativa e jurisprudencial em matéria de biotecnologia na UE}

Os países da União Europeia (UE) são responsáveis por 28,5\% do total de patentes em biotecnologias submetidas no sistema PCT, em 2001 - sendo a Alemanha responsável por $25 \%$ do total da UE. Consolida-se o esforço unionista europeu como segundo principal player global em P\&D de biotecnologias, associado a ações práticas, como a participação no The bioeconomy to 2030: designing a policy agenda.

Há 2 fontes diversas de tutela às patentes biotecnológicas: (a) aquelas decorrentes de países da UE de forma independente (não unionista) e com exigibilidade e revocabilidade nacional, como a EPC (European Patent Convention) e o EPO; e (b) normas da própria UE, dentre as quais a mais relevante é a Diretiva 98/44/EC. A Diretiva não substitui ou exige a criação de um direito especial que substitua os direitos de patentes nacionais; entretanto, estabelece algumas diretrizes e orientações que devem ser adotadas/incorporadas nos ordenamentos locais.

Ademais, mister destacar como importante fonte complementar do direito também o "case law" das decisões do EPO, que oferecem diretrizes adicionais na análise da patenteabilidade de invenções biotecnológicas.

Por fim, existe ainda uma orientação geral de alinhamento com os acordos internacionais que pode ser reavaliada caso surjam conflitos ou dúvidas quanto à adequação de protocolos internacionais às orientações específicas dos ordenamentos patentários da UE - por exemplo, não necessariamente as disposições do TRIPS se sobrepujam às determinações da EPC, ou seja, não a vinculam.

As origens do direito patentário europeu remontam ao século XVIII, com o surgimento, na França, da lei de patentes durante a Revolução Francesa. Referido diploma legal tinha por objetivo permitir a inovação tecnológica e permitir o crescimento industrial. À época, apenas a distinção em relação a matérias vivas e inanimadas se mostrava 
relevante para que se determinasse a sua patenteabilidade, sendo as últimas caracterizadas pela intervenção do homem ${ }^{268}$.

Em Novembro de 1843, foi concedida na Finlândia patente que introduziu um novo método para a produção de culturas de levedura (Patente 3). Já no ano de 1869, a empresa BASF obteve patente de processo de biotecnologia destinado à sintetização do corante alizarina, derivado originalmente da raiz da garança. Logo em seguida, em Julho de 1873, o microbiologista Louis Pasteur patenteou seu método melhorado de produção de levedura no Escritório de Patentes Francês.

O próximo marco legislativo relevante foi a adesão da Europa ao UPOV, o que foi verificado apenas no ano de 1961.

Em 1973, ocorreu a Conferência Diplomática de Munique, para o estabelecimento do Sistema Europeu para Concessão de Patentes, em que se assinou a EPC, instituindo a Organização Europeia de Patentes, que tem como órgão executivo o Escritório Europeu de Patentes (EPO).

No mês de Outubro de 1977, entrou em vigor a EPC, que regula os procedimentos para concessão de patentes, e que tem como principal característica a autorização de proteção de invenções relacionadas à tecnologia genética e farmacológica.

De acordo com a EPC, em seu artigo 52(1), os requisitos básicos para concessão de patentes a invenções em qualquer ramo da tecnologia - inclusive as matérias biológicas serão a novidade, a atividade inventiva e aplicação industrial ${ }^{269}$. Já o artigo 52(2), por sua vez, esclarece que são ilícitas as patentes relacionadas a descobertas; e os artigos 52(4) e 53 estabelecem, respectivamente, a impossibilidade de patenteamento de processos cirúrgicos, diagnósticos e terapêuticos, bem como de processos biológicos relacionados a plantas e animais.

268 "Initially, patents only concerned inanimate matter and living things were excluded. A distinction existed between so-called natural products that is, those existing in nature, and man-made products, and only the latter could be covered by a right of intellectual property" (FRANCHITTO, N; GAVARRI, L; TELMON, N; ROUGÉ, D. Comment on the provisions of the French laws of 6 August 2004 and 8 December 2004 relative to the protection of genetic inventions. Med Law, vol 25, n. 2, Jun. 2006, p. 380).

${ }^{269}$ Artigo 52(1), EPC, in verbis: "European patents shall be granted for any inventions, in all fields of technology, provided that they are new, involve an inventive step and are susceptible of industrial application". 
A matéria viva, em geral, não é excluída de patenteabilidade na EPC - já se estabeleceu que plantas e sementes não devem constituir per se uma exceção à patenteabilidade, apenas por representarem matéria viva ou com base na ideia que recursos genéticos devem ser mantidos como "herança comum da humanidade"270.

O exame de um pedido de patente para uma sequência gênica deve estar sujeita, portanto, aos mesmos critérios de patenteabilidade vigentes em outras áreas de tecnologia (inclusive a aplicação industrial).

Em 1991, o EPO estabeleceu que as reivindicações de patente não mais poderiam ser baseadas em simples considerações técnicas; os relatórios descritivos de tais pedidos deveriam ser detalhados e suficientes para se demonstrar que o objeto é passível de ser patenteado, tendo em vista as consequências sociais que podem se originar do sistema de proteção patentária ${ }^{271}$. E, neste mesmo ano, em decisão inédita o EPO rejeitou oposição feita a pedido de patente de sequência de DNA humano, sustentando que a proteção patentária em questão não significaria o patenteamento da vida humana, por entender que seria "impossible to create a human being out of the total of all genes even if all genes of the human genome would be cloned and patented",272.

Em 1994, foi editada na França a Lei 94.654, que versa sobre a doação e uso de elementos e produtos originados do corpo humano e afins e proíbe expressamente a patenteabilidade do conhecimento total ou parcial do gene humano, bem como a clonagem. O seu artigo 3, em especial, modifica os artigos 16-1 a 16-9 do Código Civil Francês, a fim

\footnotetext{
${ }^{270}$ Conforme decisão do Board of Appeal do EPO de $\mathrm{n}^{\circ} \mathrm{T}$ 0356/93 (Plant cells), OJ 1995, “(a) As plant genetic resources were the heritage of mankind, they had to remain available to all without restriction and to be preserved intact for future generations. Permitting patent protection for genetically engineered plants was against these principles. Moreover, there were concerns about the dominion that was sought to be exercised over the natural world.". No entanto, "In the board's judgment, none of the claims of the patent in suit refer to subject-matter which relates to a misuse or destructive use of plant biotechnological techniques because they concern activities (production of plants and seeds, protection of plants from weeds or fungal diseases) and products (plant cells, plants, seeds) which cannot be considered to be wrong as such in the light of conventionally accepted standards of conduct of European culture."

271 "Already in 1991 the European Patent Office (EPO) announced, that the granting of patents no longer depends on purely technical considerations; from now on, applications will have to bear scrutiny in respects of their wider social implications. The utilization of the data received is at stake - and therewith a huge scientific as well economic potential" (SIMON, Jürgen. Patent Law \& Biotechnology: Current situation and future challenges from a European perspective. Revue Hellénique de Droit International, vol. 56, 2003, p. $352)$.

${ }^{272}$ SIMON, Jürgen. Patent Law \& Biotechnology: Current situation and future challenges from a European perspective. Revue Hellénique de Droit International, vol. 56, 2003, p. 352.
} 
de esclarecer que sobre o corpo humano, seus elementos e seus produtos não deveriam incidir direitos de propriedade. ${ }^{273}$

A preocupação da UE com relação à necessidade de harmonizar e aperfeiçoar a proteção de patentes biotecnológicas existe há décadas e teve como marco a Diretiva 98/44/EC. Por meio da publicação de referida diretriz, buscou-se uma proteção eficaz e harmonizada para preservar e incentivar os investimentos no domínio na área da biotecnologia, visando a evitar possíveis entraves comerciais e produtivos dentro da própria UE.

A Diretiva 98/44/EC foi incorporada como norma de aplicação subsidiária ao EPC por decisão dos estados-membros da $\mathrm{UE}^{274}$. Posteriormente, veio a ser implementada pelas legislações nacionais e por regras da EPC; além disso, o EPO criou as Diretrizes de Exame (Guidelines for Examination in the European Patent Office) ${ }^{275}$.

De acordo com Diretiva 98/44/EC, seriam patenteáveis as invenções que impliquem atividade inventiva e sejam suscetíveis de aplicação industrial, ainda que seu objeto contenha material biológico ou envolva processo que permita produzir, tratar ou utilizar determinado material biológico.

\footnotetext{
${ }^{273} \mathrm{http}$ ://legifrance.gouv.fr/affichTexte.do;jsessionid=E119A74CAE3D26DF88BBC860556021C8.tpdjo17v_ 3? cidTexte=JORFTEXT000000549619\&categorieLien $=\mathrm{id}$

274 "In Europe, a debate on biotechnology patents started in the late 1980s with the aim of clarifying the distinction between what is patentable and what is not, and harmonising EU member states' laws in this area. This led to the adoption on 6 July 1998 of EU Directive 98/44/EC on the legal protection of biotechnological inventions ('biopatent directive'). The directive has been implemented by all EU member states. As early as 1999, the EPC contracting states decided to incorporate the directive as secondary legislation into the Implementing Regulations to the EPC. Together with the EPC articles on substantive patent law, these rules now provide the basis for deciding on the patentability of biotechnology applications at the EPO. The incorporation of the EU directive into the EPC strengthened the practice of the EPO in biotechnology, whilst putting greater focus on ethical considerations." (European Patent Office. Patents on biotechnology. Disponível em: https:/www.epo.org/news-issues/issues/biotechnology.html. Acesso em: 08/12/14).

${ }^{275}$ A Diretiva influenciou diretamente a redação das diretrizes: "2a.1 "Biotechnological inventions" are inventions which concern a product consisting of or containing biological material or a process by means of which biological material is produced, processed or used. "Biological material" means any material containing genetic information and capable of reproducing itself or being reproduced in a biological system. In principle, biotechnological inventions are patentable under the EPC. For European patent applications and patents concerning biotechnological inventions, the relevant provisions of the Convention are to be applied and interpreted in accordance with the provisions of Rules 23b-e. European Union Directive 98/44/EC of 6 July 1998 on the legal protection of biotechnological inventions (OJ 2/1999, 101) is to be used as a supplementary means of interpretation. In particular the recitals (EU Dir. 98/44/EC, rec.) preceding the provisions of the Directive are also to be taken into account." (http://legis.obi.gr/ESPACEDVD/legal_texts/gui_lines/e/c_iv_2a_1.htm)
} 
Tal diretiva permite que tanto os produtos quanto os processos biotecnológicos sejam patenteáveis. Contudo, havia à época - e ainda há - preocupações éticas relacionas à questão do patenteamento de materiais biológicos ${ }^{276}$. Por tal motivo, acabou por ser incluída disposição no sentido de que as agências governamentais patentárias das jurisdições locais teriam que avaliar o impacto de tais invenções contra a ordem pública e os bons costumes. A Diretiva 98/44/EC, contudo, não estabelece um rol taxativo de invenções que se enquadrariam como contrárias à ordem pública e aos bons costumes; porém, foram listadas algumas diretrizes para nortear os serviços nacionais de patentes e o poder judiciário.

Em 2001, foi concedida à empresa Myriad Genetics a patente europeia do gene BRCA1, relacionado ao câncer de mama, que cobre todos os métodos terapêuticos e $\operatorname{diagnósticos}^{277}$, fato este que gerou muitas polemicas em especial em França ${ }^{278}$.

A Lei de 6 de Agosto de 2004, da França, leva a uma interpretação restritiva das diretrizes da Diretiva Europeia. A referida lei rejeita o modelo de patente de produto, permitindo a proteção por patentes apenas de invenções que se constituam na aplicação técnica de uma função de um elemento do corpo humano, conforme estabelece o seu artigo 17, a seguir reproduzido:

"Art. 17. (...) Only an invention constituting the technical application of a function of an element of the human body may be protected by a patent (...)".

Nessas condições, o elemento somente poderia ser protegido caso seja um requisito para a utilização de uma aplicação específica, que deverá ser descrita de forma concreta e precisa na reivindicação da patente. Referido dispositivo legal mostra-se de grande

\footnotetext{
276 "Biotechnological inventions are general patentable. Anyhow, ethical aspects have to be considered within the proceedings of granting a patent. The ethical evaluation is carried out by the Commissions European Group on Ethics in Science and New Technologies, Article 7 of the directive" (SIMON, Jürgen. Patent Law \& Biotechnology: Current situation and future challenges from a European perspective. Revue Hellénique de Droit International, vol. 56, 2003, p. 356).

277 "'SS] even years after Myriad Genetics first identified the sequence of brcal, the European Patent Office (EPO) granted the company three patents covering all potential diagnostic and therapeutic applications based on the gene's sequence." (LECRUBIER, Aude. Patents and public health. EMBO reports, vol. 3, n. 12, 2002, p. 1120).

278 "Moreover, geneticists in France can offer genetic tests for breast cancer for less than the US\$2,680 fee per test that is charged by Myriad. It is both the breadth of Myriad's BRCA1 patent and the company's refusal to grant licenses for BRCA1-mutation detection that has led to concerted and international opposition" (ANDREWS, Lori B. Genes and patent policy: rethinking intellectual property rights. Nature Reviews - Genetics, vol. 3, Out. 2002, p. 804).
} 
importância por buscar um balanceamento no âmbito de proteção patentária, ao limitar a proteção apenas à aplicação reivindicada, porquanto tal prática deixa de constituir entrave aos desenvolvimentos biotecnológicos subsequentes ${ }^{279}$.

No mesmo sentido, foi também editada em França a Lei de 8 de Dezembro de 2004, que também limita o escopo das patentes biotecnológicas, ao definir precisamente a invenção genética. Os direitos conferidos pela patente apenas irão cobrir uma aplicação técnica em particular que seja devidamente explicitada, e a sequência genética em que a invenção é baseada pode levar a novas patentes se novas aplicações técnicas forem inventadas $^{280}$.

Em 2005, importante decisão publicada pelo $\mathrm{EPO}^{281}$ sobre métodos diagnósticos em seres humanos e animais é publicada, estabelecendo que não são passíveis de reivindicação patentária de método nos termos do artigo 52(4) do EPC. Segundo a jurisprudência do EPO, os métodos diagnósticos praticados no corpo humano envolvem as 4 etapas de exame: (a) a fase de exame, envolvendo coleta de dados; (b) a comparação dos resultados com padrões e (c) identificação de eventuais desvios significativos; e (d) atribuição do eventual desvio a um estado clínico particular.

Em 2008, caso WARF/Thomson (G 2/06 $)^{282}$, no qual o Enlarged Board of Appeal do EPO decidiu que, em função do artigo 28(c) do EPC, não seria possível conceder uma patente a uma invenção relacionada a produto biotecnológico cuja produção envolva o uso e a destruição de embriões humanos ainda que tais métodos não sejam parte de tal reivindicação patentária ${ }^{283}$.

\footnotetext{
279 "The new Law of 6 August 2004 carries the same reasoning further. The first inventor's claim to a gene sequence can in no way be an obstacle to a later claim related to the same sequence if the latter is also useful and necessary for a technical application, different from the first" (FRANCHITTO, N; GAVARRI, L; TELMON, N; ROUGÉ, D. Comment on the provisions of the French laws of 6 August 2004 and 8 December 2004 relative to the protection of genetic inventions. Med Law, vol 25, n. 2, Jun. 2006, p. 384).

280 "The protection conferred by the patent thus covers the secondary invention only for the function clearly described in the patent application, or more precisely for the technical application which constitutes the prior invention." (FRANCHITTO, N; GAVARRI, L; TELMON, N; ROUGE, op. cit., p. 384).

${ }^{281}$ Decisão G1/04, do Enlarged Board of Appeal of the EPO (http://www.epo.org/law-practice/case-lawappeals/recent/g040001ep1.html)

${ }_{282}$ Decisão disponível em http://www.epo.org/law-practice/case-law-appeals/recent/g060002ex1.html; acesso em 24/11/2014.

${ }^{283}$ Decisão reiterada em 2014: http://www.epo.org/law-practice/case-law-appeals/recent/t102221eu1.html; acesso em 24/11/2014.
} 
Em outubro de 2011, o caso Brüstle v. Greenpeace eV, C-34/10, EU:C:2011:669, tratou do uso de embriões humanos para fins industriais e comerciais. Segundo o Tribunal de Justiça Europeu (CJEU), mesmo que os óvulos humanos utilizados na pesquisa não venham a ser fertilizados, deverão ser encarados como embriões. Tal entendimento encontra fundamento na Diretiva 98/44/EC, que estabelece a impossibilidade de patenteamento quando o respeito à dignidade humana possa ser afrontado. Por consequência, o STJE entende ser pertinente uma interpretação mais ampla ao conceito de “embrião humano" contido no artigo 6(2)(c) das Diretiva 98/44/EC ${ }^{284}$. Referido entendimento foi bastante criticado não apenas pela indústria da biotecnologia, mas também pela própria comunidade científica:

\begin{abstract}
"The scientific community reacted negatively to the ECJ decision. For instance, Professor Sir Ian Wilmut, one of the creators of the cloned sheep Dolly, was quoted as saying: 'It is very much to be regretted that the [ECJ] has taken this view. It will unfortunately make it less likely that companies in Europe will invest in the research to develop treatments to use embryonic stem cells for treatment of human diseases. ${ }^{\prime 285}$
\end{abstract}

Em agosto de 2012, a International Stem Cell Corporation requereu duas patentes relativas a células-tronco derivadas de óvulos humanos não fertilizadas que foram partenogenicamente ativados para estimular a divisão celular (“parthenotes”). Muito embora tal pedido tenha sido rejeitado com base no julgamento do CJEU no caso Brüstle $v$. Greenpeace (http://www.ipo.gov.uk/p-challenge-decision-results/o31612.pdf), em grau de apelação a requerente obteve decisão favorável no ano de 2014, tendo em vista que os "parthenotes" morrem no estágio de blastoma, incapazes de continuar se dividindo e se desenvolvendo e, portanto, nunca chegando a se tornar um ser humano.

\footnotetext{
284 "That classification must also apply to a non-fertilised human ovum into which the cell nucleus from a mature human cell has been transplanted and a non-fertilised human ovum whose division and further development have been stimulated by parthenogenesis. Although those organisms have not, strictly speaking, been the object of fertilisation, due to the effect of the technique used to obtain them they are, as is apparent from the written observations presented to the Court, capable of commencing the process of development of a human being just as an embryo created by fertilisation of an ovum can do so" European Court of Justice. Oliver Brüstle v. Greenpeace e.V., julgado dia 18/10/2011. Disponível em 08/12/14 (http://curia.europa.eu/juris/document/document.jsf?text=\&docid=111402\&pageIndex $=0 \&$ doclang=EN\&mo $\mathrm{de}=1 \mathrm{st} \& \mathrm{dir}=\& \mathrm{occ}=$ first\&part $=1 \& \mathrm{cid}=561326)$.

${ }^{285}$ Patents in Europe 2013/2014. Biotechnology patentability - the latest from the EPO. Disponível em: http://www.jakemp.com/uploads/files/publishedarticles/Patents_in_Europe_Biotechnology_patentability_the_latest_from_the_EPO.pdf
} 


\subsubsection{Patenteamento de invenções biotecnológicas na UE}

Segundo as normas europeias relativas à proteção patentearia na área de biotecnologia, seriam consideradas matérias patenteáveis: (a) material biológico isolado do meio natural ou produzido por meio de um processo técnico, mesmo que ocorresse previamente na natureza - incluindo-se as sequências gênicas, desde que tenham uma função atribuída a elas ${ }^{286}$; (b) plantas ou animais se a viabilidade técnica da invenção não está limitada a uma particular variedade de planta ou animal - pedido em que as variedades não sejam especificamente reivindicadas ${ }^{287}$; (c) processo microbiológico ou outro processo técnico e produtos obtidos por meio de tal processo (que não uma específica variedade de planta ou animal).

A Diretiva 98/44/EC, em seu artigo $5^{\circ}$, estabelece que a mera descoberta de elementos do corpo humano não é patenteável, mas um elemento isolado do corpo humano, ou produzido por um processo técnico pode constituir uma invenção patenteável.

A Diretiva 98/44/EC reconhece, ainda, que uma invenção que diga respeito a um elemento isolado do corpo humano ou produzido de qualquer outra forma por processo técnico suscetível de aplicação industrial não é excluída da patenteabilidade, mesmo que a estrutura do elemento preexista na natureza e seja idêntica à de um elemento natural, sendo certo que os direitos conferidos pela patente não abrangem o corpo humano. Já o EPC reconhece que um elemento isolado do corpo humano, incluindo-se sequência (total ou parcial) de um gene, poderá ser considerada uma invenção, mesmo se sua estrutura seja idêntica àquela do elemento naturalmente ocorrente.

Além disso, a aplicação industrial da sequência genética deve ser claramente discriminada no pedido de patente. O ponto em questão é a diferenciação entre o processo

\footnotetext{
${ }^{286}$ Diretiva 44/98/EC, artigo 3, "1. For the purposes of this Directive, inventions which are new, which involve an inventive step and which are susceptible of industrial application shall be patentable even if they concern a product consisting of or containing biological material or a process by means of which biological material is produced, processed or used. 2. Biological material which is isolated from its natural environment or produced by means of a technical process may be the subject of an invention even if it previously occurred in nature."

${ }^{287}$ Diretiva 44/98/EC, artigo 4: “1. The following shall not be patentable: (a) plant and animal varieties; (b) essentially biological processes for the production of plants or animals. 2. Inventions which concern plants or animals shall be patentable if the technical feasibility of the invention is not confined to a particular plant or animal variety. 3. Paragraph 1(b) shall be without prejudice to the patentability of inventions which concern a microbiological or other technical process or a product obtained by means of such a process."
} 
de descoberta, que consiste na simples identificação de uma sequência, e o processo voltado para inovação, que identifica a aplicação industrial dessa sequência.

A necessidade de especificação da aplicação industrial (artigo 5.3) pode ser entendida de forma a estabelecer uma concepção restritiva ao objeto da patente, ou seja, os direitos advindos apenas se referiam à aplicação industrial especificada no pedido de patente.

Um processo essencialmente biológico não cumpre os quesitos de novidade e atividade inventiva, e, portanto, não é patenteável - a dificuldade encontra-se na definição do que é um processo essencialmente biológico, o que deve ser feito caso a caso. Uma mera descoberta não é patenteável, mas a substância pode gerar um efeito técnico, permitindo a patenteabilidade - um gene descoberto na natureza pode ser patenteável se um efeito técnico é demonstrado.

De outro lado, a EPC define uma lista não exaustiva dos conteúdos ou atividades que não são considerados invenções, a saber: (a) invenções cuja publicação ou exploração seja contrária à ordem pública ou à moralidade; (b) variedade de planta ou animal ou processos essencialmente biológicos (consistentes apenas em um fenômeno natural, discutindo-se, caso a caso, o grau de intervenção humana no processo) para a produção de plantas ou animais - essa vedação não se aplica aos processos microbiológicos ou seus produtos; (c) invenções biotecnológicas (produtos consistindo de material biológico ou o contendo ou processo por meio do qual o material biológico é produzido, processado ou usado - material biológico é qualquer material contendo informação genética capaz de reproduzir-se ou ser reproduzida em um sistema biológico) que digam respeito a (i) processos de e para clonagem de seres humanos, (ii) processos para modificar a identidade genética germinal de seres humanos, (iii) uso de embriões humanos para propósitos comerciais ou industriais, (iv) processos para modificar a identidade genética de animais e que possam lhes causar sofrimento, sem qualquer benefício (pesquisa, prevenção, diagnóstico, terapia) ao homem ou aos animais, e os animais resultantes desses processos.

A exclusão não se aplica a produtos, substâncias e composições para uso em tais métodos. E, ainda, métodos de caráter essencialmente técnico são patenteáveis - como 
métodos para medir ou registrar características do corpo humano ou animal, assim como tratamentos puramente cosméticos.

\subsection{Requerimentos de patenteabilidade em geral - análise comparativa}

Em comparação com os EUA, a UE conta com um processo regulatório mais cauteloso e menos direto com relação aos produtos ou processos patenteáveis, o que se soma ao fato de que há as regulamentações nacionais específicas.

No sistema americano, há os requisitos de novidade, utilidade e não-obviedade, não sendo o caráter técnico explícito na legislação dos EUA. Excetuam-se à matéria patenteável os produtos da natureza, as leis da natureza e/ou fenômenos naturais, ideias abstratas e conhecimento ou pensamento humano básico.

De outro lado, inexiste óbice à concessão de reivindicações patentárias relacionadas a matérias vivas - desde que, obviamente, os requisitos para concessão da tutela patentária sejam verificados. A partir do caso Chakrabarty, originou-se o requisito de características marcadamente diferentes dos produtos da natureza; deste modo, num primeiro momento sustentou-se que os genes isolados/purificados seriam patenteáveis, uma vez que tais procedimentos evidenciariam uma forma de intervenção técnica humana marcante, distinguindo-os dos genes naturalmente ocorrentes.

Tal entendimento, contudo, foi superado recentemente pela decisão da Suprema Corte Americana no caso Myriad Genetics, que reconheceu o requisito da novidade apenas no cDNA, ao sustentar que a mera extração do DNA de seu ambiente natural não alteraria suas características (sua sequência de nucleotídeos), que são essenciais tanto à sua função biológica quanto à sua função em pesquisas.

Quanto aos métodos terapêuticos e diagnósticos, a jurisprudência americana já anotou ser necessário mais do que simples coleta, análise e comparação de dados para que se reconheça sua patenteabilidade. Nos EUA, entendeu-se que a análise e comparação de sequências genéticas se relacionam com processos mentais abstratos e, por isso, não são transformativas nem patenteáveis; para tanto, deve haver a descrição de uma aplicação 
específica, particular e inventiva em qualquer requerimento de patente desta natureza, o que evidencia a preocupação americana em não inibir futuros desenvolvimentos por bloquear o uso de ferramentas básicas do trabalho científico e tecnológico.

No sistema europeu, as patentes são concedidas a invenções com aplicação industrial que sejam novas e envolvam um passo inventivo (inventive step) - a tecnicidade da invenção é evidente enquanto requisito de patenteabilidade. Exclui-se da patenteabilidade aquilo que for abstrato ou não-técnico.

O entendimento europeu é no sentido de que invenções novas, mesmo se incidirem sobre matéria biológica, são patenteáveis - e a matéria biológica isolada do ambiente natural ou produzida por processo técnico pode ser objeto de invenção, ainda que preexista no estado natural. Muito embora a Diretiva 98/44/EC não estabeleça um rol taxativo de invenções que se enquadrariam como contrárias à ordem pública e aos bons costumes, há diretrizes para nortear os serviços nacionais de patentes e o poder judiciário.

$\mathrm{Na}$ UE, reconhece-se a possibilidade de patenteamento de matéria viva; contudo, a EPC proíbe expressamente o patenteamento de métodos diagnósticos praticados no corpo humano, em que pese os métodos per se sejam patenteáveis, a teor do quanto dispõe o artigo 52(4) do EPC.

$\mathrm{Na}$ UE entende-se que um processo essencialmente biológico não deve cumprir os quesitos patenteabilidade; contudo, embora as descobertas não sejam patenteáveis, a intervenção humana que lhe gere um efeito técnico poderá permitir sua patenteabilidade, o que quer dizer que gene extraído da natureza pode ser patenteável se um efeito técnico é demonstrado, ainda que sua estrutura seja idêntica à do elemento natural.

Por fim, em que pese não seja expressamente determinado o elemento da "utilidade" daquilo que se pretende obter patente na UE - como ocorre com os EUA - fato é que legislações internadas de países europeus, como é o caso da França, já se posicionaram no sentido de reconhecer a essencialidade de tal elemento não apenas para se caracterizar a novidade e o passo inventivo, mas também para limitar a proteção patentária à efetiva contribuição apresentada. 
Pode-se dizer que, no Brasil, os pressupostos autorizadores da concessão patentária são bastante similares àqueles estabelecidos na UE. Da mesma forma, o tratamento brasileiro conferido aos métodos terapêuticos e diagnósticos, cuja proteção patentária também não é reconhecida.

Entretanto, no que tange às patentes biotecnológicas, pode-se verificar importantes traços distintivos em determinados aspectos com relação a tais jurisdições, dentre as quais importa destacar a proibição de proteção patentária sobre matéria viva, bem como de matéria biológica isolada de seu ambiente natural.

Muito embora a lei brasileira proíba o patenteamento de seres vivos naturais e materiais biológicos encontrados na natureza (ainda que dela isolados), tal regra foi excepcionada - dentre outros - pela permissão de se patentear microrganismos que atendam aos requisitos de patenteabilidade, por considerá-los compostos químicos.

Dentro deste contexto, e considerando-se interpretação do próprio INPI, é possível inferir que as sequências de DNA isoladas/purificadas não integram o âmbito de proteção patentária no Brasil, porém o cDNA seria albergado pela tutela das patentes por ser considerado um composto químico. Neste mister, portanto, o Brasil se alinha com a atual orientação americana, no que diz respeito ao não reconhecimento da novidade em material biológico extraído (isolado/purificado) de seres vivos. 


\section{CONCLUSÕES}

A proposta do presente estudo consistiu na análise acerca da possiblidade do patenteamento de genes humanos e em que condições tal forma de proteção poderia ser aplicada, bem como se aplicação de tal tutela jurídica se mostraria necessária e/ou socialmente justificável.

Tendo sido tal hipótese confirmada, em seguida discutiu-se quais seriam as formas possíveis de se compatibilizar o direito de excluir terceiros da exploração econômica de processos/produtos de origem genética, em contraposição à eventual necessidade de se conferir acesso aos genes por se tratar de "ferramenta de base" para o desenvolvimento de novos inventos biotecnológicos.

À luz desse contexto, buscou-se então fundamentação econômica e social para delimitar a extensão da proteção a ser atribuída às patentes genéticas. Referida análise teve por objetivo, de um lado, assegurar a existência de incentivos aos agentes privados para fins de se atrair os necessários investimentos ao setor, e, de outro, evitar que a outorga de direitos de exclusividade patentária configure entrave ao desenvolvimento técnicocientífico.

De posse de tais elementos, passou-se então a mapear entendimentos doutrinários, legais e jurisprudenciais no Brasil e no direito comparado, a fim de identificar pela possibilidade de enquadramento de uma tutela patentária sustentável, voltada à proteção dos genes humanos no Brasil - que seja social e economicamente sustentável - ou se eventual reforma legislativa seria necessária e/ou desejável.

O ponto de partida deste estudo foi a demonstração da importância do setor biotecnológico e o interesse social envolvido nas inovações técnicas que vêm sendo disponibilizadas nas últimas décadas, notadamente em razão de soluções trazidas em âmbito da saúde pública. Viu-se que em âmbito genético o fator preponderante nos desenvolvimentos tecnológicos é a ciência experimental, sendo excessivamente demorados e custosos, além da incerteza de seus resultados. 
A importância de se buscar investimentos em P\&D no setor da engenharia genética por meio da concessão de direitos intelectuais vinculados aos processos e produtos deles originados revelou-se imperativa, sob pena de ser verificada uma estagnação no progresso biotecnológico.

Após serem analisados e discutidos os mecanismos jurídicos possíveis (diretos de autor e direitos de propriedade industrial), e comparados com um cenário desprovido de qualquer tutela, verificou-se que a proteção patentária seria a que melhor se adequa ao fomento das invenções biotecnológicas.

Viu-se que um ambiente marcado pela ausência de tutela patentária - quando desprovida de políticas públicas capazes de adequadamente financiar/motivar o desenvolvimento científico acadêmico biotecnológico (em especial aquelas relacionadas a pesquisas de base em genética médica) - incentiva os trade secrets, especialmente em razão da exposição a comportamentos econômicos parasitários dos concorrentes.

Além de se tratar de uma situação não desejável socialmente, porquanto potencialmente geradora de ineficiências econômicas, pode também paralisar ou limitar a continuidade do progresso técnico-científico do setor - tudo em razão da restrição ao acesso a conhecimentos técnicos relevantes, já previamente alcançados e disponíveis. Ademais, viu-se que a proteção jurídica aos segredos de negócio não seria tão efetiva quanto as tutelas relativas a direitos intelectuais. Assim, a inexistência de qualquer proteção legal aos desenvolvimentos genéticos geraria o risco dessa informação ser mantida em segredo.

Da mesma forma, viu-se que os direitos autorais não constituem forma adequada à proteção dos genes e aplicações práticas. De modo geral, os direitos de autor referem-se à proteção da forma/meio de expressão subjetiva de um conteúdo - no caso, de natureza técnico-científica - e não ao seu conteúdo propriamente dito.

A proteção do conteúdo de um desenvolvimento genético alcançado pela via do direito autoral não seria eficiente, haja vista que terceiros não seriam excluídos de produzir e explorar comercialmente "versões" de tal desenvolvimento biotecnológico, o que - em última análise - significa dizer que as informações genéticas e as finalidades a que se 
prestam estariam disponíveis para exploração comercial a terceiros, potencialmente concorrentes, que não se oneraram com os investimentos (recursos técnicos, financeiros, recursos humanos, e outros) necessários para que se chegasse a tal resultado.

Ficou assim demonstrado no Capítulo 3.1.3 que a forma mais acertada para se atrair os vultosos investimentos necessários para se permitir a continuidade do avanço da engenharia genética seria pela da outorga da tutela patentária. Por meio da proteção patentária, é possível que se imponha a terceiros uma limitação à exploração econômica do desenvolvimento tecnológico alcançado.

Trata-se de uma ferramenta mais economicamente interessante tanto sob a ótica dos inventores (ou seus financiadores) - pois permite que os resultados obtidos de um determinado projeto de $\mathrm{P} \& \mathrm{D}$ possam ser explorados sem que qualquer terceiro lhe possa fazer concorrência - quanto sob a ótica da sociedade - já que o pedido de patente exige divulgação do objeto a ser patenteado, tornando público esse conhecimento. O direito precário conferido ao "inventor" do objeto e/ou processo a ser protegido refere-se a uma retribuição do Estado pela divulgação de tal invento.

Para tanto, à outorga de direitos patentários deve preceder criteriosa análise para que se possa identificar a existência de alguns pressupostos básicos que a justifique - caso contrário, tal ferramenta consistiria em insustentável mecanismos de limitação da concorrência, cujos efeitos negativos ao mercado e a toda coletividade seriam óbvios.

Ora, no Brasil - bem como em diversas outras jurisdições - o fundamento da proteção patentária reside no interesse social e desenvolvimento econômico e tecnológico do país. Deve existir, para tanto, uma contribuição técnica/científica de elevada importância, voltada à solução de um problema técnico ${ }^{288}$. Para tanto, em linhas gerais é universalmente ${ }^{289}$ reconhecido que a concessão de uma patente depende da verificação de algumas condições cumulativas: deve ser nova, não óbvia e possuir aplicação industrial.

\footnotetext{
${ }^{288}$ Para BOSTYN, segundo a lógica dos princípios básicos da lei de patentes seria necessário haver uma divulgação da informação em contrapartida à concessão da patente, "in such a way that the man skilled in the art is able to carry out the invention with the aid of the information provided in the patent application and the prior art" (BOSTYN, 2003, op. cit. p. 86).

${ }^{289}$ Refere-se aqui a diretrizes básicas reconhecidas e aceitas nas mais diversas jurisdições do globo, tendo-se como referência o Acordo sobre os Aspectos dos Direitos de Propriedade Intelectual Relacionados ao
} 
A questão da novidade em biotecnologia é aspecto central, dado que todo o material biológico pode ser encontrado na natureza de forma espontânea, via de regra. $\mathrm{O}$ critério da novidade reside, contudo, na disponibilidade do material genético de forma diferente daquela existente em seu meio nativo, em condições que não podem ser reproduzidas espontaneamente na natureza.

A matéria biológica pré-existente em seu estado natural não é suscetível de proteção patentária, notadamente por inexistir qualquer contribuição humana para sua existência, e portanto não pode ser caracterizada como invenção. Neste contexto individualmente considerado, não seria possível o patenteamento de genes existentes no corpo humano - ou mesmo parte dele, como preconiza a LPI; a proibição relacionada aos produtos da natureza deve, portanto, bloquear o patenteamento de sequências de DNA naturalmente ocorrentes.

Já a matéria biológica naturalmente ocorrente que seja isolada/purificada de seu ambiente original, ou mesmo aquela produzida sinteticamente por meio de um processo técnico laboratorial não estaria excluída, a priori, da proteção conferida pela tutela patentária. Isso se deve ao fato de que suas características físicas são distintas daquelas verificadas nos genes nativos correspondentes.

Em que pese o entendimento jurisprudencial de algumas jurisdições limite tal reconhecimento apenas aos genes sinteticamente reproduzidos em laboratório, pode-se sustentar que os genes isolados/purificados podem ser igualmente considerados produtos inexistentes, inacessíveis e tampouco aptos para uso, a não ser pela intervenção humana direta.

$\mathrm{O}$ requisito da inventividade distingue um trabalho rotineiro daquele que envolva desenvolvimento tecnológico originado de trabalho criativo humano. Da mesma forma, os avanços evidentes ou óbvios do estado da técnica que podem ser alcançados por uma pessoa média cuja área técnica lhe seja afeta (simples inovação) não apresentam tal requerimento.

Comércio ("TRIPS"); entretanto, há diversas nuances e especificidades que devem ser consideradas e respeitadas, conforme legislações locais. 
Embora exista uma grande proximidade entre os genes enquanto "matérias-primas" de produtos e os processos biotecnológicos propriamente ditos, tal fato não justifica qualquer tipo de limitação ao direito de se reconhecer o valor criativo originado da ação humana que traga um resultado útil capaz de solucionar um problema técnico. E, como se teve a oportunidade verificar ao longo deste trabalho, a engenharia genética é atualmente setor tecnológico dos mais importantes e promissores, especialmente em vista das potenciais aplicações e utilidades práticas que poderão se originar.

Esta noção deve ser interpretada de forma mais ampla, devendo ser considerada também a importância da alocação dos recursos organizacionais, instrumentais e financeiros necessários para que seja viabilizada a realização de projetos de $\mathrm{P} \& \mathrm{D}$ em âmbito biotecnológico. Ainda que tal interpretação extensiva extrapole o âmbito da criação intelectual como critério necessário à caracterização de uma invenção, tais aspectos não podem ser ignorados.

Por fim, deve-se ainda analisar se o produto ou processo que se pretende patentear possui uma aplicação industrial. De modo sintético, uma invenção terá aplicação industrial quando puder ser fabricado em série ou utilizado em qualquer classe de indústria.

Pode parecer a priori que reivindicações de patentes envolvendo processos e produtos genéticos sejam insubsistentes, uma vez que a estrutura físico-química se mostra similar àquela ocorrente de modo espontâneo na natureza, e, ato contínuo, a função biológica que determinada sequência deve possuir (por serem inerentes aos próprios genes naturalmente verificados).

Entretanto, para que seja possível a proteção da sequência de DNA pretendida, o requerente da patente deverá indicar qual é a aplicação prática que tal função biológica pode desempenhar para um determinado problema técnico. Ora, se a lógica do sistema patentário busca premiar os resultados práticos, seria coerente atribuir a exclusividade apenas a este último.

A forma de proteção patentária tradicional (aplicada às invenções mecânicas), deve em princípio englobar toda e qualquer forma de exploração do objeto/processo protegido, 
desde que presentes os requisitos acima apresentados. Tal situação, contudo, deve ser avaliada com maior cuidado no âmbito da proteção patentária no campo da engenharia genética.

O motivo de tal alegação encontra guarida no fato de que a essência de um gene e, portanto, sua importância técnica e econômica - reside na informação genética por ele carreada, e não em sua estrutura física ${ }^{290}$. Desta constatação emerge a importância do critério da utilidade, que é presente em algumas jurisdições (e que no Brasil, muito embora não se mostre presente de forma expressa, encontra suporte em importantes doutrinas, sendo sustentada pelo argumento de que este seria justamente o elemento distintivo capaz de justificar a exploração econômica do invento).

Como visto, trata-se de requisito dotado de elevado grau de relevância na análise de reivindicações de patentes biotecnológicas, notadamente no que tange à área da engenharia genética, em razão da qualificação dos genes enquanto informação, revestindo-se, portanto, de caraterística de matéria-prima para tais desenvolvimentos. O patenteamento de genes poderia assim significar o irrestrito controle de todo o seu conteúdo informacional (que deve possuir incontáveis aplicações possíveis, obviamente desconhecidas em sua totalidade no momento do requerimento da patente).

A identificação de outras funções ou finalidades que venham a ser atribuídas posteriormente poderá, pois, estar subordinada aos detentores dessas patentes originais, mesmo quando se tratem de projetos de $\mathrm{P} \& \mathrm{D}$ realizados de forma autônoma e independente, buscando resultados e aplicações distintos e não vinculados.

Tal fato poderá ter impactos negativos para inovações subsequentes, haja vista que inexistem bens ou processos substitutos que possam viabilizar o desenvolvimento técnicocientífico da engenharia genética - posto que os genes isolados/purificados e os genes sinteticamente produzidos, embora distintos e novos em relação aos genes nativos equivalentes, deverão codificar a mesma informação, sendo este o fator preponderante nas invenções genéticas.

${ }^{290}$ Como esclarece MARQUES, o gene “(...) neste contexto, raramente o significado tem como referência o paradigma corporal; e é certo que é, sobretudo, a informação genética o objecto de maior interesse" (MARQUES, op. cit., p. 89). 
Tendo em vista que as patentes importam em exceção ao princípio da livre concorrência, devem elas ser aplicadas restritivamente, de forma necessária e suficiente para que sua finalidade imediata seja alcançada. Caso contrário, haveria um desvio de finalidade do sistema patentário, fundamentado no afastamento do interesse social e do desenvolvimento econômico e social.

Com reivindicações apropriadamente limitadas, genes como objeto de patentes não seriam problemáticas, uma vez que estariam limitadas ao estado da técnica e ao escopo da divulgação feita pelo inventor, mantendo-se disponíveis os genes para pesquisas ulteriores que busquem efeitos e aplicações diversas.

Neste contexto, a adoção de uma tutela relativa mostra-se uma hipótese razoavelmente capaz de assegurar os necessários incentivos ao setor, limitando os direitos de seu detentor à sua efetiva contribuição, em relação ao estado da técnica verificado no ato da reivindicação da outorga de tal direito. Isso porque, neste caso, as sequências de DNA protegidas não vinculariam as invenções subsequentes.

Para tanto, aponta a patente de aplicação como mecanismo de proteção mais adequado, por descrever um processo envolvendo um produto biológico que desempenha uma determinada função. Não se trataria, portanto, de uma simples patente de produto, pois a reivindicação patentária seria qualificada por uma descrição que deverá circunscrever de modo necessário e suficiente a finalidade pratica da aplicação que se pretende proteger.

Seria assim possível sustentar a proteção patentária vinculada às aplicações descritas, o que de outro lado autorizada as tutelas às patentes de $2^{\circ}$ uso em âmbito genético, visto que neste contexto não haveria uma apropriação do gene enquanto "matérias primas" para desenvolvimentos subsequentes.

As patentes de processos, por sua vez, não parecem ser uma regra no âmbito das inovações relacionadas à engenharia genética. Muito embora seja possível se vincular um resultado ou aplicação prática a um determinado processo, as metodologias atuais de extração de genes naturais se mostram atualmente padronizadas e rotineiras. 
Em primeiro lugar, os métodos relacionados à purificação e isolamento de genes, bem como sua síntese laboratorial mostram-se uniformes e automáticos na atualidade. Nada obstante, os métodos diagnósticos e terapêuticos são também expressamente excluídos da proteção patentária por meramente reproduzirem/descreverem aplicações das leis da natureza, fenômenos naturais e/ou ideias abstratas. Os processos biotecnológicos somente poderão ter sua patenteabilidade reconhecida quando atrelados a outros aspectos adicionais substanciais que revelam uma forma de intervenção importante, que não envolve a mera sobreposição e/ou combinação de conhecimentos de domínio público.

Atualmente, o sistema de propriedade industrial brasileiro não considera "o todo ou parte dos seres vivos naturais e materiais biológicos encontrados na natureza, ou ainda que dela isolados, inclusive o genoma ou germoplasma de qualquer ser vivo natural e os processos biológicos naturais" (artigo 10, inciso IX, da LPI). De outro lado, o artigo 18, inciso III, reconhece que os microrganismos são patenteáveis por não serem considerados parte isolada de um ser vivo.

Os genes devem ser analisados pelo INPI, portanto, como substâncias químicas, de modo que os requisitos de patenteabilidade deverão recair sobre os requisitos das patentes químicas.

Com relação à forma de proteção a ser outorgada, viu-se também que muito embora não exista previsão expressa a respeito das patentes de uso no direito brasileiro, tal possibilidade é factível e já foi reconhecida e recepcionada pela jurisprudência pátria.

Isso quer dizer que a proteção patentária aos genes humanos deverá estar atrelada a uma intervenção humana que apresente um resultado prático útil, estando a ela limitada. Por tal argumento, e mesmo à luz da exclusão legal da proteção patentária aos genes isolados/purificados, pode-se sustentar que a proteção de patentes de aplicação aos genes vinculadas - e limitadas - à utilidade prática descrita na reivindicação patentária não constituiria um problema: os genes isolados/purificados não seriam indevidamente apropriados pelo detentor da patente, que teria o direito da exclusiva patentária circunscrito à sua invenção. Ora, não devia possuir ela tratamento diferente daquele dispensado ao gene 
sinteticamente produzido tendo vista o caráter informacional que ambos devem apresentar de modo idêntico, uma reconhecida a novidade em ambas as formas.

Este parece ser o caminho para se justificar a viabilidade de se conferir a proteção patentária aos genes humanos que descrevam determinada aplicação, não apenas àqueles sinteticamente produzidos em laboratório, mas também os genes isolados/purificados de seu meio natural, uma vez que eles nada mais são do que compostos químicos com estruturas marcadamente diferentes em relação aos genes nativos, originados da intervenção do homem.

Pela estrita observância ao sistema patentário atual, a flexibilidade necessária para se lidar com as novidades poderia ser alcançada. Neste caso, contudo, a as condições e extensão desta possível patenteabilidade deverá ser considerada à luz de todos os aspectos anteriormente considerados, de modo a se assegurar o atingimento dos fundamentos de validade e existência do sistema patentário. 


\section{REFERÊNCIAS BIBLIOGRÁFICAS}

Abbot J. Diagnostic testing of genetic disorders: limiting the scope of patent claims through disclosure requirements. J Law Med;14(1): 110-26, 2006 Aug.

ACOG - American College of Obstetricians and Gynecologists. Patents, Medicine, and the Interests of Patients. ACOG Committee Opinion n 277, vol. 100. 5 Nov. 2002.

Adler RG. Biotechnology as an intellectual property. - Science;224(4647): 357-63, 1984 Apr 27.

Albertini, Lorenzo. L'invenzione biotecnologica: requisiti di brevettabilità ed estensione della protezione. Contratto e Impresa. Padova. v.23. n.4/5. p.1059-123. lug1./ott. 2007.

Alberts, Bruce, et al, Fundamentos da Biologia Celular, 3a ed. Porto Alegre: Artmed, 2011.

Allison M. Diagnostics firms face new patent claim worries. - Nat Biotechnol;27(7): 586-7, 2009 Jul.

Amaral Júnior, Alberto do. O acordo TRIPS, a licença compulsória e os países em desenvolvimento. São Paulo, 2006. p. 99-116. Revista do Tribunal Regional Federal da $3^{a}$ Região, São Paulo, n. 79, p. 99-116, set./out. 2006.

Anderson C. US patent application stirs up gene hunters. Nature;353(6344): 485-6, 1991 Oct 10.

Anderson I. Gene patent granted: now the real fight begins. New Sci;103(1420): 7, 1984 Sep 6.

Andrews, Lori B. Genes and patent policy: rethinking intellectual property rights. Nature Reviews - Genetics, vol. 3, Out. 2002 
Arroyo Perez, Héctor Leandro. Como combater a biopirataria utilizando a lei de patentes estadunidense. Revista de Direitos Difusos. São Paulo. v.7. n.38. p.39-53. jul/ago. 2006.

Ascarelli, Tullio. Teoría de la concurrencia y de los bienes inmateriales. Barcelona: Bosch, 1970. (citado por Newton Silveira)

Avancini, Helenara Braga. Genoma humano reflexão ética sobre a (im)possibilidade da patenteamento do patrimônio genético humano. Revista da ABPI. Rio de Janeiro. n.72. p.23-32. set./out. 2004.

Baquero, P. Propriedade Intelectual em Questão: entre a ética e o utilitarismo. O Caso da Patenteabilidade dos Genes Humanos. Revista dos Estudantes de Direito da Universidade de Brasília, n. 7, 2008.

Barbieri, José Carlos; Álvares, Antonio Carlos Teixeira. Estratégia de Patenteamento e Licenciamento de Tecnologia: Conceitos e Estudo de Caso, Revista Brasileira de Gestão de Negócios, v. 7, n. 17, p. 58-68, 2005.

Barbosa, Denis Borges. Uma introdução à propriedade intelectual. $2^{\mathrm{a}}$ edição. Rio de Janeiro: Lumen Iuris, 2003.

Barbosa, Denis Borges. As Bases Constitucionais Do Sistema De Proteção Das Criações Industriais. In: Santos, Manoel J. Pereira; Jabur, Wilson Pinheiro (Coord.). Propriedade Intelectual: Criações Industriais, Segredos de Negócio e Concorrência Desleal. São Paulo: Editora Saraiva, 2007.

Barbosa, Denis Borges. A questão do segundo uso farmacêutico. Parecer. Setembro de 2004.

Barbosa, Denis Borges. Direito de autor: questões fundamentais de direito de autor. Rio de Janeiro: Lumen Juris, 2013. 
Barbosa, Denis Borges. Tratado da Propriedade Intelectual, vol. II. Rio de Janeiro: Editora Lumen Juris, 2010.

Barcellos, Milton Lucídio Leão. Patentes na área da biotecnologia e direitos fundamentais. Revista da ABPI. Rio de Janeiro. n.76. p.22-31. maio/jun. 2005.

Barral, Welber; Pimentel, Luiz Otávio. Direito de Propriedade Intelectual e Desenvolvimento. In: Barral, Welber; Pimentel, Luiz Otávio. Propriedade Intelectual e Desenvolvimento. Florianópolis: Boiteux, 2007.

Barros, Carla Eugênia Caldas. O aperfeiçoamento, a dependência, a licença e a propriedade nas patentes. São Paulo: C. E. C. Barros, XIII, 2002.

Becker, Konrad. B. Are natural gene sequences patentable? Int. Arch. Occup. Environ. Health, vol. 73, 2000.

Bergmans, B. Les limites generales a la breve tabilite des inventions biologiques. Bruxelles: Annales de Droit de Louvain. v.52. n.2, 1992.

Berlinguer, Giovanni. Ciência, mercado e patentes do DNA humano. Brasília: Bioética. v.8. n.1. p.97-106. 2000 .

Bobbio, Norberto. O positivismo jurídico: lições de filosofia do direito. São Paulo: Ícone, 1996.

Boff, Salete Oro. Patentes na biotecnologia e desenvolvimento. In: Barral, Welber; Pimentel, Luiz Otávio. Propriedade Intelectual e Desenvolvimento. Florianópolis: Boiteux, 2007.

Bostanci A; Calvert J. Invisible genomes: the genomics revolution and patenting practice. Stud Hist Philos Biol Biomed Sci;39(1): 109-19, 2008 Mar.

Bostyn, S. J. R. One Patent a Day Keeps the Doctor Away? European Journal of Health Law, 7(3), 09/2000 (ISSN: 0929-0273). 
Bostyn S. J. R. The prodigal son: the relationship between patent law and health care. Med Law Rev;11(1): 67-120, 2003.

Bradshaw J. Gene patent policy: does issuing gene patents accord with the purposes of the U.S. patent system? Willamette Law Rev;37(4): 637-60, 2001.

Brody B. Intellectual property and biotechnology: the European debate. Kennedy Inst Ethics J;17(2): 69-110, 2007 Jun.

Brush, Stephen B. Indigenous Knowledge of Biological Resources and Intellectual Property Rights: The Role of Anthropology. American Anthropologist, New Series, Vol. 95, No. 3. Sep., 1993

Bull, Alan T.; Holt, Geoffrey; e Lilly, Malcom D. Biotechnology, international trends and perspectives. Paris: OCDE, 1982.

Cabrera Medaglia, Jorge. Acceso a los recursos genéticos y el papel de los derechos de propiedad intelectual. Revista de Ciências Jurídicas. San José. n.91. p.51-63. ene./abr. 2000.

Casabona, Carlos Maria Romeo. Do gene ao Direito: sobre as implicações jurídicas do conhecimento e intervenção no genoma humano. São Paulo: IBCrim, 1999.

Caskey, Tomas C. Gene patents - a time to balance access and incentives. TIBTECH, vol. 14, Agosto 1996.

Caulfield T. Policy conflicts: gene patents and health care in Canada. Community Genet;8(4): 223-7, 2005.

Cerqueira, João da Gama. Tratado da propriedade industrial, vol. I. $2^{\mathrm{a}}$ ed. rev. e atualizada por Luiz Gonzaga do Rio Verde e João Casimiro da Costa Neto. São Paulo: Ed. Revista dos Tribunais, 1982. 
Chahine KG. Anchoring gene patent eligibility to its constitutional mooring. Nat Biotechnol;28(12): 1251-5, 2010 Dec.

Coase, Ronald H. "The Problem of Social Cost", The Firm, the Market, and the Law. Chicago: University of Chicago Press, 1990.

Cook-Deegan R. Patent law. Law and science collide over human gene patents. Science;338(6108): 745-7, 2012 Nov 9.

Cooter, Robert D; Schaefer, Hans-Bernd. Solomon's knot: how law can end the poverty of nations. Princeton: Princeton University Press, 2012.

CORIAT, Benjamin. O Novo Regime Global de Propriedade Intelectual e Sua Dimensão Imperialista: Implicações paras Relações Norte-Sul. Traduzido e Publicado pelo BNDES no livro “Desafios para o Crescimento”, 2002.

Correia, Eduardo; Moita, Rodrigo. Gasto em P\&D e Poder de Mercado: Teoria e Evidência para o Brasil. Pesquisa e Planejamento Econômico (IPEA), v. 41, n. 1, abr. 2011.

Couto, Joao Goncalves do. Patentes de invenção. Rio de Janeiro: Jacintho Ribeiro dos Santos, 1923.

Crespi RS. An analysis of moral issues affecting patenting inventions in the life sciences: a European perspective. Sci Eng Ethics;6(2): 157-80, Abril de 2000.

Cretella Júnior, José. Curso de Direito Romano, $18^{\mathrm{a}}$ ed. Rio de Janeiro: Forense, 1995

Cunningham BC. Impact of the Human Genome Project at the interface between patent and FDA laws. Risk;7(3): 253-66, 1996.

Dal Poz, Maria Ester. Da Dupla à Tripla Hélice: o Projeto Genoma Xylella. Dissertação de Mestrado - Departamento de Política Científica e Tecnológica, Universidade Estadual de Campinas, Campinas, 2000. 
Dal Poz, Maria Ester. Propriedade Intelectual em Biotecnologia. In: Propriedade intelectual: contratos de propriedade intelectual e novas tecnologias. Santos, Manoel J. Pereira dos; Jabur, Wilson Pinheiro (coord.). 2. ed. São Paulo: Saraiva, 2009.

Del Nero, Patrícia Aurélia. Propriedade intelectual a tutela jurídica da biotecnologia. 2. ed. revista, atualizada e ampliada. São Paulo, Ed. Revista dos Tribunais, 2004.

Del Nero, Patrícia Aurélia. Biotecnologia análise crítica do marco jurídico regulatório. São Paulo: Editora Revista dos Tribunais, 2009.

Devlin, Alan. The Misunderstood Function Of Disclosure In Patent Law. Harvard Journal of Law \& Technology, vol. 23, $\mathrm{n}^{\mathrm{o}}$ 2, Primavera/2010.

Diniz, Maria Helena. O Estado Atual do Biodireito. São Paulo: Editora Saraiva, 2007.

Di Cataldo, Vincenzo. Biotecnologie e diritto. Verso un nuovo diritto, e verso un nuovo diritti dei brevetti. Contratto e Impresa. Padova. v.19. n.1. p.319-94. genn./apr. 2003.

Di Cataldo, Vincenzo. L'originalità dell'invenzione. Milano: A. Giuffrè, 1983.

Domingues, Douglas Gabriel. Engenharia genética e a proteção legal de embriões. Revista do Centro de Ciências Jurídicas. Belém. v.2. n.1. p.121-35. 1989.

Domingues, Douglas Gabriel. Microrganismo per se, produtos e processos da biotecnologia de fronteira e o direito de patentes brasileiras. Revista do Tribunal de Justiça do Estado do Pará. Belém. v.31. n.42. p.37-54. 1987.

Dominguez Lacasa, Iciar; Reiss, Thomas. Influence of policies and general settings on actor performance in biotechnology. Fraunhofer Institute Systems and Innovation Research - Draft. Karlsruhe: EPOHITE, 2001. 
Dutfield, Graham. Intellectual property rights, trade, and biodiversity seeds and plant varieties. London: IUCN, World Conservation Union, 2000.

Eisenberg R. Patenting genome research tools and the law. C R Biol;326(10-11): 1115-20, 2003 Oct-Nov.

Feldman R. Whose body is it anyway? Human cells and the strange effects of property and intellectual property law. Stanford Law Rev;63(6): 1377-402, 2011 Jun.

Fellmeth AX. The challenge to patent law of pure chemical protein synthesis. Nat Biotechnol;23(5): 547-9, 2005 May.

Fernandes, Marcia Santana. Bioética, Medicina e Direito de Propriedade Intelectual Relação entre patentes e células-tronco humanas. São Paulo: Saraiva, 2012.

Fernández-Novoa; Rodríguez, Carlos. El enriquecimiento injustificado en el Derecho Industrial. Barcelona: Marcial Pons, 1998.

Fontes, André R. C. Patente, invenção e inovação. Revista da Escola da Magistratura Regional Federal da $2^{a}$ Região. Rio de Janeiro, jul. 2011.

Franchitto N; Gavarri L; Telmon N; Rougé D. Comment on the provisions of the French laws of 6 August 2004 and 8 December 2004 relative to the protection of genetic inventions. Med Law;25(2): 379-87, jun. 2006.

Friedman, David D.; Landes, William M.; Posner, Richard A. Some Economics of Trade Secret Law. Journal of Economic Perspectives, vol. 5, no. 1, Inverno/1991.

Garcia, Balmes Vega. Direito e tecnologia regime jurídico da ciência, tecnologia e inovação. São Paulo: Editora LTr, 2008.

García Domínguez, Jorge. Un acercamiento a la patentabilidad de las invenciones biotecnológicas. Revista de la Facultad de Derecho y Ciencias Politicas de la Universidad Pontificia Bolivariana. Medellin. v.36. n.104, jan./jun, 2006. 
Gênova, Leonardo de. Patente de biotecnologia: evolução e perspectivas. Revista da ABPI. Rio de Janeiro. n.95, jul./ago. 2008.

Goldstein, Jorge A.; Golod, Elina. Human gene patents. Academic Medicine, vol. 77, $\mathrm{n}^{\mathrm{o}}$ 12, Dezembro/2002.

Grau, Eros Roberto. Elementos de direito econômico. Revista dos Tribunais, São Paulo, 1981.

Guise, Mônica Steffen. Comércio Internacional e Propriedade Intelectual. In: Barral, Welber; Pimentel, Luiz Otávio. Propriedade Intelectual e Desenvolvimento. Florianópolis: Boiteux, 2007.

Hammes, Bruno Jorge. O direito de propriedade intelectual, $3^{\text {a }}$. Ed. São Leopoldo: Unisinos, 2022.

Hazuka, Christopher D. Supporting the work of lesser geniuses: an argument for removing obstructions to human embryonic stem cell research. University of Miami Law Review. Miami. v.57. n.1, out. 2002.

Hettinger, Edwin C. Justifying Intellectual Property. Philosophy and Public Affairs, Vol. 18, No. 1, Inverno/1989.

Hollon, Tom. Gene patent revisions to remove some controversies. Nature Medicine, vol. 6, no. 4, Abril/2000.

Holman, Christopher M. Patent border wars: defining the boundary between scientific discoveries and patentable inventions. Trends in Biotechnology, vol. 25, $\mathrm{n}^{\mathrm{o}} 12$, Dezembro de 2007.

Huys I; Van Overwalle G; Matthijs G. Gene and genetic diagnostic method patent claims: a comparison under current European and US patent law. Eur J Hum Genet;19(10): out. 2011. 
Iacomini, Vanessa. Biotenologia: repercussões jurídicas e sociais da pesquisa sobre genoma humano. In: Barral, Welber; Pimentel, Luiz Otávio. Propriedade Intelectual e Desenvolvimento. Florianópolis: Boiteux, 2007.

Ilbert, Hélène. Tubiana, Laurence. Protection juridique des inventions biotechnologiques analyse de la directive européenne et propositions. Madrid: Marcial Pons, 1997.

Jackson, Brian A. Innovation and Intellectual Property: The Case of Genomic Patenting. Journal of Policy Analysis and Management, vol. 22, no. 1, Maio/2003.

Jannuzzi, Anna Haydée Lanzillotti; Vasconcellos, Alexandre Guimarães; Souza, Cristina Gomes. Especificidades do patenteamento no setor farmacêutico: modalidades da proteção intelectual. Revisão, cad. Saúde Pública, Rio de Janeiro, vol. 24, nº 6, junho/2008.

Kaiser J. Intellectual property. Patent sprawl: from genes to gene interpretation. Science;302(5652): 1878, 2003 Dec 12.

Kinch Pérez, Melanie L. Anything under the sun - un análisis de los problemas morales de la legislácion sobre patentes del ADN humano. Revista Jurídica de la Universidad de Puerto Rico. Rio Piedras. v.76. n.4, 2007.

Kintisch E. Intellectual property. Court tightens patent rules on gene tags. Science;309(5742): 1797-9, 16 set. 2005.

Kluge, Eike-Henner W. Patenting Human Genes: When Economic Interests Trump Logic and Ethics. Health Care Analysis, vol. 11, n 2, Junho/2003.

Labrunie, Jacques. Direito de patentes condições legais de obtenção e nulidades. São Paulo: Manole, 2006.

Landes, William M., Posner, Richard A. The economic structure of intellectual property law. Cambridge: Harvard University Press, 2003 
Lecrubier, Aude. Patents and public health. EMBO reports, vol. 3, n. 12, 2002.

Lee B; Kim T; Kim SK; Lee KH; Lee D. Patome: a database server for biological sequence annotation and analysis in issued patents and published patent applications. Nucleic Acids Res;35(Database issue): D47-50, Jan. 2007.

Leite, Márcio de Oliveira Junqueira. O patenteamento de invenções de segundo uso no Brasil. 27/04/2011. Dissertação (Mestrado em Direito) - Faculdade de Direito da Universidade de São Paulo. São Paulo, 2011.

Leschot NJ; Mannens MM. The disquieting consequences of granting patents on human genes for healthcare and scientific research in The Netherlands. Ned Tijdschr Geneeskd;148(35): 1712-5, 2004 Aug 28.

Loureiro, Luiz Guilherme de Andrade Vieira. Biotecnologia e patente: as disposições da nova lei de propriedade industrial. Revista dos Tribunais. São Paulo. v.86. n.739, maio. 1997.

Loureiro, Luiz Guilherme de Andrade Vieira. Patente e biotecnologia: questões sobre a patenteabilidade dos seres vivos. Revista de Direito Mercantil, Industrial, Econômico e Financeiro. São Paulo. v.39. n.116, out./dez. 1999.

Luna Filho, Eury Pereira. Legislação Brasileira Para O Desenvolvimento Industrial E Tecnológico. Rio de Janeiro: Cnpq, 1979.

Magalhães, Vladimir Garcia. O patenteamento de moléculas biológicas naturais no EUA e União Europeia. Revista da Faculdade de Direito da Universidade de São Paulo. São Paulo. v.101. jan./dez. 2006.

Marques, João Paulo Remédio. Patentes de Genes Humanos? Coimbra: Coimbra Editora, 2001. 
Marshall E. Patent policy. Amicus brief unfriendly to gene patents. Science;330(6005): 746-7, 2010 Nov 5.

Martin-Rendon E; Blake DJ. Patenting human genes and stem cells. Recent Pat DNA Gene Seq;1(1): 25-34, 2007.

Meinhardt, Peter. Inventions, patents and monopoly. London: Stevens \& sons, limited, 1946.

Merges Robert P. Intellectual property in higher life forms: the patent system and controversial technologies. MD Law Rev;47(4), 1988.

Merges, Robert P. Of Property Rules, Coase, and Intellectual Property. Columbia Law Review, 1994.

Merges, Robert P.; Nelson, Richard R. On the Complex Economics of Patent Scope. Columbia Law Review, 1990.

Meyers, Thomas C.; Turano, Thomas A.; Greenhalgh, Duncan A.; Waller, Patrick R.H. Patent protection for protein structures and databases. Nature Structural Biology, Nov/2000.

Metcalfe, Joseph Staley. Equilibrium and evolutionary foundations of competition and technology policy: new perspectives on the division of labour and the innovation process. In: Workshop - Frontiers and trends: frontiers of innovation research and policy, Instituto de Economia, UFRJ: Rio de Janeiro, 2002.

Miller JA. Gene engineering: patent for products. Sci News;126(10): 150, 1984 Sep 8.

Miranda, Pontes de; Bitelli, Marcos Alberto Sant'Anna (atual.). Tratado de Direito Privado - Parte Especial - Tomo XVI - Direito das Coisas, Propriedade Intelectual, Propriedade Industrial. Editora Revista dos Tribunais, São Paulo, 2012. 
Mossinghoff GJ. The evolution of gene patents viewed from the United States Patent Office. Adv Genet;50, 2003.

Müller, Ana Cristina Almeida; Pereira Junior, Nei; Antunes, Adelaide Maria de Souza. Escopo das reinvindicações e sua interpretação. Revista da ABPI. Rio de Janeiro. n.53. jul./ago. 2001.

Murphy, Sean D. Biotechnology and international law. Harvard International Law Journal. Cambridge. v.42. n.1, 2001.

Nicol D. Balancing innovation and access to healthcare through the patent system an Australian perspective. Community Genet;8(4): 228-34, 2005.

Nicol, Dianne; Nielsen, Jane. The Autralian medical biotechnology industry and access to intelectual property: issues for patent law development. The Sydney Law Review. Sydney. v.23. n.3, set. 2001.

Nowak R. Gene therapy. Patent award stirs a controversy. Science;267(5206): 1899, 31 mar. 1995.

Nussbaum, Robert L.; McInnes, Roderick R.; Willard, Huntington F.; Thompson, Margaret Wilson; Hamosh, Ada. Thompson and Thompson genetics in medicine, 7. ed., Saunders/Elsevier,2007.

Olsson, H. Commercialization of genes breast cancer gene patent is a pilot case. Sweden must play a part in the development. Lakartidningen;96(37), 15 Set. 1999.

Ostergard Jr, Robert; Tubin, Matthew; Altman, Jordan. Stealing from the past: globalisation, strategic formation and the use of indigenous intellectual property in the biotechnology industry. Third World Quarterly, vol. 22, n 4, 2001.

Paradise J; Janson C. Decoding the research exemption. Nat Rev Genet;7(2): 148-54, 2006 Feb. 
Pierce BL; Carlson CS; Kuszler PC; Stanford JL; Austin MA. The impact of patents on the development of genome-based clinical diagnostics: an analysis of case studies. Genet Med;11(3), Mar. 2009.

Pinto, Paulo Brossard de Souza. Criações intelectuais resultantes de engenharia genética tutela legal. Revista Forense. Rio de Janeiro. v.101. n.377. p.255-61. jan./mar. 2005.

Pizzoferrato, Alberto. Brevetto per invenzione e biotecnologie. Padova: CEDAM, 2002.

Philipp, Fernando Eid. Patente de invenção extensão da proteção e hipóteses de violação. 1a ed. São Paulo: Editora Juarez de Oliveira, 2006.

Pooley, James. Trade Secrets - the other IP right. WIPO Magazine, vol. 3, 2013.

Posner, Richard A. Intellectual Property: The Law and Economics Approach. Journal of Economic Perspectives, vol. 19, nº 2, Primavera/2005.

Rayol, Alice. Tendências de exame dos pedidos de patente na área de biotecnologia. Revista da ABPI. Rio de Janeiro. n.63. p.49-56. jul. 2002.

Read, A.; Strachan, T., Human Molecular Genetics. Nova Iorque: Garland Science, 2011.

Ridley A; Nicol D. Is there still a place for gene patents in Australia? Implications of recent United States and European case law. - J Law Med;19(2), Dez. 2011.

Rifkin, Jeremy. O século da biotecnologia: a valorização dos genes e a reconstrução do mundo. São Paulo: Ed. Makron Books, 1999.

Robinson, Douglas; Medlock, Nina. Diamond v. Chakrabarty: A Retrospective on 25 Years of Biotech Patents. Intellectual Property \& Technology Law Journal, Vol. 17, $\mathrm{n}^{\mathrm{o}} .10$. Out. 2005. 
Rosenberg, Barbara. Huck, Hermes Marcelo (Orient). Patentes de medicamentos $e$ comércio internacional os parâmetros do TRIPS e do direito concorrencial para a outorga de licenças compulsórias. São Paulo, 2004.

Salomão Filho, Calixto. Direito concorrencial - as estruturas. São Paulo: Malheiros, 2007.

Samuelson, Pamela. Innovation and Competition: Conflicts over Intellectual Property Rights in New Technologies. Science, Technology, \& Human Values, vol. 12, n 1 , Inverno, 1987.

Scherer FM. The economics of human gene patents. Acad Med;77(12 Pt 2), Dez. 2002.

Schilling SH. DNA as patentable subject matter and a narrow framework for addressing the perceived problems caused by gene patents. Duke Law J;61(3), Dez. 2011.

Scholze, Simone Henriqueta Cossetin. Propriedade intelectual e biotecnologia: aspectos jurídicos e éticos. Notícia do Direito Brasileiro. Brasília. n.5. Jan./Jun. 1998.

Schonmann A. From make believe to doomsday eve: or should we patent genes? Med Law;17(3), 1998.

Schumpeter, Joseph Alois. Capitalismo, socialismo e democracia. Rio de Janeiro: Editora Fundo de Cultura, 1961.

Schwartz, Andrew A. The Corporate Preference for Trade Secret. Northwestern Law, Abril/2013.

Scotchmer, Suzanne. Innovation and incentives. Cambridge: MIT Press, 2004.

Shapiro, Carl. Navigating the Patent Thicket: Cross Licenses, Patent Pools, and Standard Setting. In: Jaffe, Adam B.; Lerner, Josh; Stern, Scott (org.). Innovation Policy and the Economy, vol. 1. Cambridge: MIT Press, 2001.. 
Sherwood, Robert M. Los sistemas de propriedad intelectual y el estímulo a la inversion: evaluación y comparación de 18 sistemas en países en vías de desarrollo. Buenos Ayres: Editorial Heliasta, 1997.

Sherwood, Robert M. Propriedade Intelectual e Desenvolvimento Econômico. São Paulo: Editora da Universidade de São Paulo, 1992.

Silva, José Afonso da. Curso de Direito Constitucional Positivo. São Paulo: Malheiros Editores, 1994.

Silveira, José Maria Jardim da; DAL POZ, Maria Ester Soares; ASSAD, Ana Lucia. Biotecnologia e recursos genéticos: desafios e oportunidades para o Brasil. Campinas: Instituto de Economia, Universidade Estadual de Campinas e FINEP, 2004.

Silveira, Newton. Curso de propriedade industrial. 2. ed. São Paulo, Revista dos Tribunais, 1987.

Silveira, Newton. Propriedade intelectual e a nova lei de propriedade industrial: Lei 9.279, 14-5-1996. São Paulo: Saraiva, 1996.

Silveira, Newton. Propriedade intelectual; propriedade industrial, direito de autor, software, cultivares. 3. ed., rev. e ampl. Barueri, Manole, 2005.

Silveira, Newton. "A utilidade das invenções, a exclusividade do registro e o dry-martini”. Migalhas, 18 jan. 2011.

Simon, Jürgen. Patent Law \& Biotechnology: Current situation and future challenges from a European perspective. Revue Hellénique de Droit International, vol. 56, 2003.

Smith II, George P; Andresen, Jensine; Taylor, Allyn L. Biotechnology, human rights, and intellectual property. Proceedings of the American Society of International Law. Washington. n.1/4, mar. 2002. 
Soares, José Carlos Tinoco. Tratado da propriedade industrial patentes e seus sucedâneos. São Paulo, Jurídica brasileira, 1998.

Straus, Joseph. Avances internacionales de los temas de propiedad intelectual en biotecnologia. Derecho de la Pontificia Universidad Catolica del Peru. Lima. n.47. Dez. 1993.

Stiglitz, Joseph E. Economic Foundations of Intellectual Property Rights. Duke Law Journal, vol 57, 2008.

Taylor. Allyn L. Biotechnology, human rights, and intellectual property. Proceedings of the American Society of International Law. Washington. n.1/4. Mar. 2002.

Timm, Luciano Benetti; Caovilla, Renato; Brendler, Gustavo. Análise Econômica da Propriedade Intelectual: Commons vs. Anticommons. In: Timm, Luciano Benetti; Braga, Rodrigo Bernardes (org.). Propriedade Intelectual. Belo Horizonte: Arraes Editores, 2011.

Tomasson M. Legal, ethical, and conceptual bottlenecks to the development of useful genomic tests. Ann Health Law;18(2), 8 p. preceding i, 2009.

Ubertazzi, Luigi Carlo. Invenzione e innovazione. Studi di diritto privato. Università degli studi di Milano. Facoltà di giurisprudenza. Milano: A. Giuffrè, 1978.

Varella, Marcelo Dias; Pereira, Marcia C. Propriedade intelectual sobre produtos da biotecnologia. Revista de Informação Legislativa. Brasília. v.33. n.130. abr./jun. 1996.

Vinarov, Sara D. Patent Protection for Structural Genomics-related Inventions. Journal of Structural and Functional Genomics, vol. 4, 2003.

Walpole, Ian R; Dawkins, Hugh J S; O'Leary, Peter C; Sinden, Peter D. Human gene patents: the possible impacts on genetic services healthcare. Med J Aust;179(4), 18 ago. 2003. 
Wolff, Maria Thereza. Diretiva da comissão europeia sobre a proteção legal de invenções biotecnológicas. Revista da ABPI. Rio de Janeiro. n.37, nov./dez. 1998.

Wolff, Maria Thereza; Antunes, Paulo de Bessa. Patentes de Segundo Uso Médico. Boletim Científico ESMPU, Brasília, a. III - n. 13, p. 115-131 - out./dez. 2004.

Xia Y; Tang L; Yao L; Wan B; Yang X; Yu L. Literature and patent analysis of the cloning and identification of human functional genes in China. Sci China Life Sci;55(3), Mar. 2012.

Zamudio, Teodora. Protección jurídica de las innovaciones patentes, D.O.V.'s, genoma humano, biodiversidad: apéndice normativo. 1. ed. Buenos Aires: Ad Hoc, 2001. 